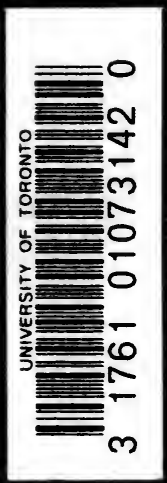




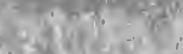

$-10$

8

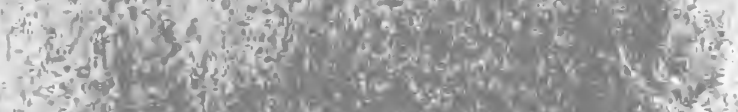

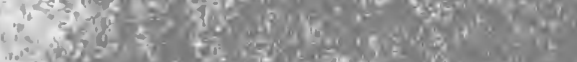

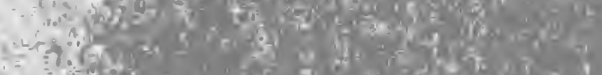

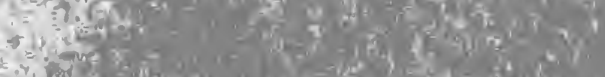

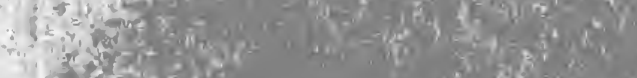

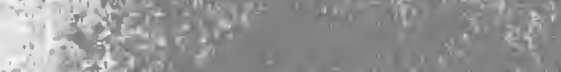

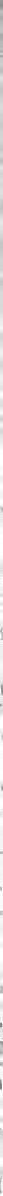


Digitized by the Internet Archive in 2007 with funding from Microsoft Corporation 

SUPERSTITIONS OF WITCHCRAFT. 
AnF
W72355

THE

\section{SUPERSTITIONS OF WITCHCRAFT'.}

$\mathrm{BY}$

\section{HOWARD WILLIAMS, M.A.}

ST. JOHN'S COLLEGE, CAMBRIDGE.

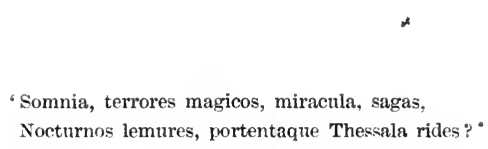

LONDON :

LONGMAN, GREEN, LONGMAN, ROBERTS, \& GREEN. 1865. 


$$
\frac{9013 / 19^{0}}{28}
$$




\section{.PREFACE.}

'The Superstitions of Witchcraft' is designed to exhibit a consecutive review of the characteristic forms and facts of a creed which (if at present apparently dead, or at least harmless, in Christendom) in the seventeenth century was a living and lively faith, and caused thousands of victims to be sent to the torturechamber, to the stake, and to the scaffold. At this day, the remembrance of its superhuman art, in its different manifestations, is immortalised in the every-day language of the peoples of Europe.

The belief in Witchcraft is, indeed, in its full development and most fearful results, modern still more than mediæval, Christian still more than Pagan, and Protestant not less than Catholic. 


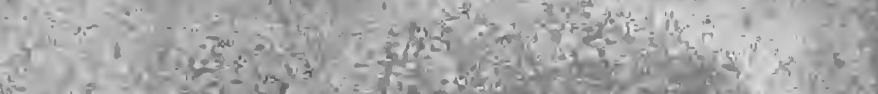

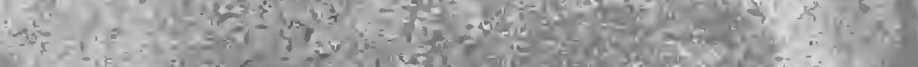

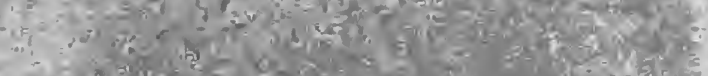

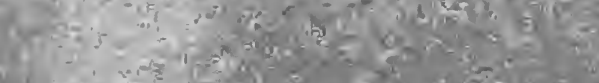

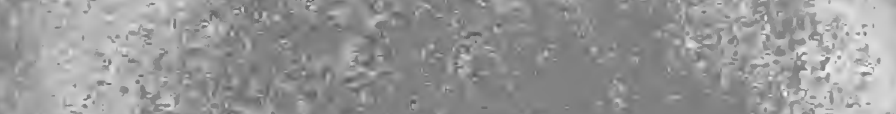

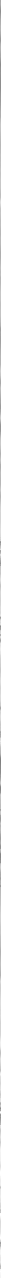




\section{CONTENTS.}

\section{PART I.}

\section{CHAPTER I.}

The Origin, Prevalence, and Variety of Superstition-The Belief in Witcheraft the most horrid Form of Superstition-Most flourishing in the Sixteenth and Serenteenth Centuries $/$ The Sentiments of Addison, Blackstone, and the Lawyers of the Eighteenth Century upon the Subject-Chaldean and Persian Magic-Jewish Witchcraft-Its important Influence on Christian and Modern BeliefGreek Pharmacy and Sorcery-Early Roman Laws against Conjuration and Magic Charms-Crimes perpetrated, under the Empire, in connection with Sorceric Practices-The general Persecution for Magic under Valentinian and Valens - German and Scandinarian Sagæ-Essential Difference between Eastern and Western Sorcery-The probable Origin of the general Belief in an Evil Principle . . . . . . . PAGE 3

\section{PAR'T II.}

\section{CHAPTER I.}

Compromise between the New and the Old Faiths-Witcheraft under the Early Church-The Sentiments of the Fathers and the Decrees of Councils-Platonic Influences-Historical, Physiolngical, and Accidental Causes of the Attribution of Witcheraft to the Female Sex-Opinions of the Fathers and other Writers-The Witch-Compact . . . . . . . . . 47 


\section{CHAPTER II.}

Charlemagne's Severity-Anglo-Saxon Superstition-Norman and Arabic Magic-Influence of Arabic Science-Mohammedan Belief in Magic-Rabbinical Learning-Roger Bacon-The Persecution of the Templars-Alice Kyteler . . . . . PAGE 63

\section{CHAPTER III.}

Witcheraft and Heresy purposely confounded by the Church-Mediæral Science closely connected with Magic and Sorcery-Ignorance of Physiology the Cause of many of the Popular Prejudices - Jeanne d'Arc-Duchess of Gloucester-Jane Shore-Persecution at Arras

\section{PART III.}

\section{CHAPTER I.}

The Bull of Innocent VIII.-A new Incentive to the rigorous Prosecution of Witcheraft-The 'Malleus Maleficarum'-Its Criminal Code-Numerous Executions at the Commencement of the Sixteenth Century-Examination of Christian Demonology - Various Opinions of the Nature of Demons-General Belief in the Intercourse of Demons and other non-human Beings with Mankind .

. 101

\section{CHAPTER II.}

Three Sorts of Witches-Various Modes of Witeheraft-Manner of Witch-Travelling-The Sabbaths-Anathemas of the Popes against the Crime-Bull of Adrian VI.-Cotemporary Testimony to the Sererity of the Persecutions-Necessary Triumph of the Orthodox Party-Germany most subject to the Superstition-Acts of Parliament of Henry VIII. against Witcheraft-Elizabeth Barton-The Act of 1562-Executions under Queen Elizabeth's GovernmentCase of Witcheraft narrated by Reginald Scot . . . 126 


\section{CHAPTER III.}

The 'Discoverie of Witchcraft,' published 1584-Wier's 'De Prestigiis Dæmonum,' \&c.-Naudé-Jean Bodin-His ‘De la Démonomanie des Sorciers,' published at Paris, 1580-His AuthorityNider-Witch-case at Warboys-Evidence adduced at the TrialRemarkable as being the Origin of the Institution of an Annual Sermon at Huntingdon . . . . . . PAGE 144

Astrology in Antiquity-Modern Astrology and Alchymy-Torralvo -Adrentures of Dr. Dee and Edward Kelly-Prospero and Comus, Types respectively of the Theurgic and Goetic Arts-Mragicians on the Stage in the Sixteenth Century-Occult Science in Southern Europe-Causes of the inevitable Mistakes of the pre-Scientific Ages . - 157

\section{CHAPTER V.}

Sorcery in Southern Europe-Cause of the Retention of the Demonological Creed among the Protestant Sects-Calvinists the most Funatical of the Reformed Churches--Witch-Creed sanctioned in the Authorised Version of the Sacred Scriptures--The Witch-Act of 1604-James VI.'s 'Demonologie'-Lycanthropy and Executions in France-The French Provincial Parliaments active in passing Laws against the various Witch-practices-Witcheraft in the Pyrenees-Commission of Inquiry appointed-Its ResultsDemonology in Spain . . . . . . . . 168

\section{CHAPTER VI.}

'Possession' in France in the Seventeenth Century-Urbain Grandier and the Convent of Loudun-Exorcism at Aix-Eestatic Phenomena-Madeleine Bavent-Her cruel Persecution-Catholic and Protestant Witchcraft in Germany-Luther's Demonological Fears and Experiences-Originated in his exceptional Position and in the extraordinary Circumstances of his Life and TimesWitch-burning at Bamburg and at Würzburg . . . 186 


\section{CHAPTER VII.}

Scotland one of the most Superstitious Countries in Europe-Scott's Relation of the Barbarities perpetrated in the Witch-trials under the Auspices of James VI.-The Fate of Agnes Sampson, Euphane MacCalzean, \&c.-Irrational Conduct of the Courts of JusticeCauses of Volnntary Witch-Confessions-Testimony of Sir G. Mackenzie, \&c. - Trial and Execution of Margaret Barclay-Computation of the Number of Witches who suffered Death in England and Scotland in the Sixteenth and Seventeenth Centuries-Witches burned alive at Edinburgh in 1608-The Lancashire WitchesSir Thomas Overbury and Dr. Forman-Margaret Flower and Lord Rosse

- PAGE 203

\section{CHAPTER VIII.}

The Literature of Europe in the Seventeenth Century proves the Universality and Horror of Witcheraft - The most acute and most liberal Men of Learning conrinced of its Reality-Erasmus and Francis Bacon-Lawyers prejudiced by Legislation-Matthew Hale's judicial Assertion-Sir Thomas Browne's TestimonyJohn Selden-The English Church least Ferocious of the Protestant Sects-Jewell and Hooker-Independent ToleranceWitcheraft under the Presbyterian Government-Matthew Hopkins-Gaule's 'Select Cases of Conscience'-Judicial and Popular Methods of Witch-discovery-Preventive Charms-Witchfinders a Legal and Numerous Class in England and Scotland-Remission in the Severity of the Persecution under the Protectorship . 219

\section{CHAPTER IX.}

Glanril's Sadducismus Triumphatus-IIis Sentiments on Witcheraft and Demonology-Baxter's 'Certainty of the World of Spirits,' \&c.-Witch Trial at Bury St. Edmund's by Sir Matthew Hale, 1664-The Evidence adduced in Court-Two Witches hangedThree hanged at Exeter in 1682-The last Witches judicially exccuted in England-Uniformity of the Eridence adduced at the Trials-Webster's Attack upon the Witch-creed in 1677-Witch Trials in England at the end of the Seventeenth Century-French Parliaments vindicate the Diabolic Reality of the Crime-Witchcraft in Sweden . . . . . . . . $23 \pi$ 


\section{CHAPTER $\mathrm{X}$.}

Witcheraft in the English Colonies in North America - Puritan Intolerance and Superstition-Cotton Mather's 'Late Memorable Providences'-Demoniacal Possession-Evidence given before the Commission-Apologies issued by Authority-Sudden Termination of the Proceedings-Reactionary Feeling against the Agitators -The Salem Witcheraft the last Instance of Judicial Prosecution on a large Scale in Christendom-Philosophers begin to expose the Superstition-Meritorious Labours of Webster, Becker, and others-Their Arguments could reach only the Educated and Wealthy Classes of Society-These only partially enfranchisedThe Superstition continues to prevail among the Vulgar-Repeal of the Witch Act in England in 1736-Judicial and Popular Persecutions in England in the Eighteenth Century - Trial of Jane Wenham in England in 1712-Maria Renata burned in Germany in 1749-La Cadière in France-Last Witch burned in Scotland in 1722-Recent Cases of Witchcraft-Protestant SuperstitionWitcheraft in the Extra-Christian World 


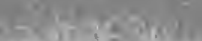

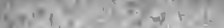

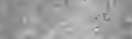

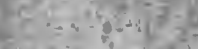

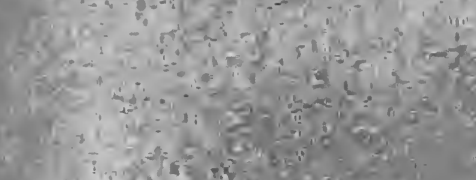

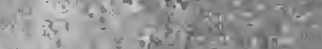

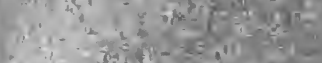

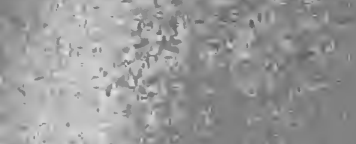

$x+\frac{1}{2}=$

ans $=y^{2}$

as 4

$=2$

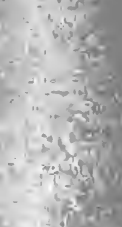

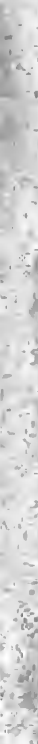

28

$t^{2}=$

\%

$3 x+3 x^{2}$

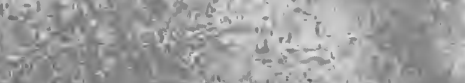

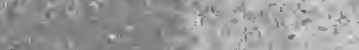

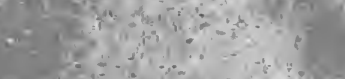
$y^{2}=t^{2}=$

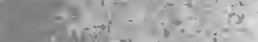

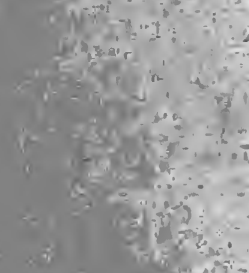
$x^{2}=x^{2}-m$

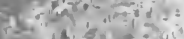

Betrats

is 401.

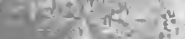

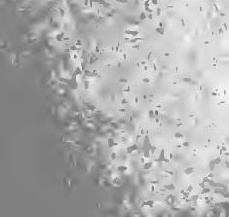

srota

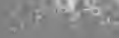

$y=$

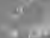

Wist

$+\infty$

c

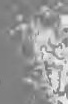

4xit

tovis

30

$\lim _{2} x$

8

$y^{1}=$

है

7

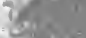


PART I.

\section{EARLIER FAITH.}




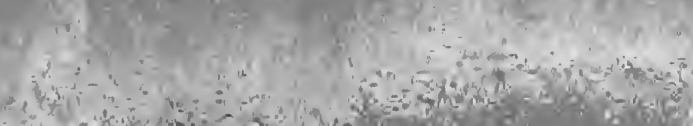

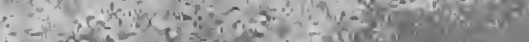

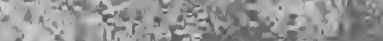

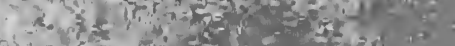

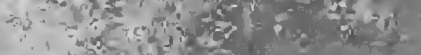

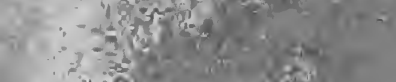

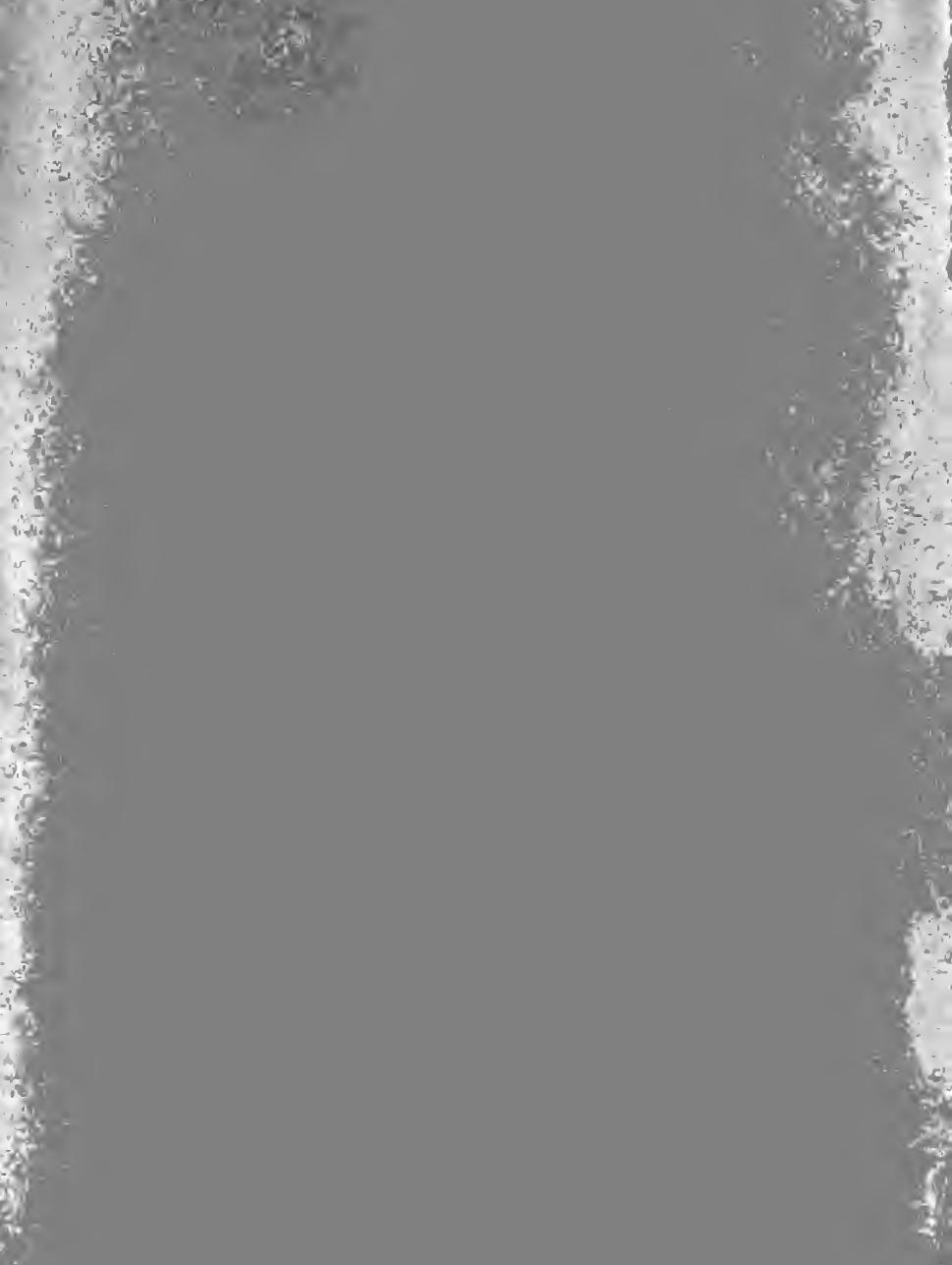

$+$ 


\section{CHAPTER I.}

The Origin, Prevalence, and Variety of Superstition-The Belief in Witcheraft the most horrid Form of Superstition-Most flourishing in the Sixteenth and Seventeenth Centuries-The Sentiments of Addison, Blackstone, and the Lawyers of the Eighteenth Century upon the Subject-Chaldean and Persian Magic-Jewish Witchcraft-Its important Influence on Christian and Modern Belief-Greek Pharmacy and Sorcery-Early Roman Laws against Conjuration and Magic Charms Crimes perpetrated, under the Empire, in connection with Sorceric Practices-The general Persecution for Magic under Valentinian and Valens-German and Scandinarian Sagæ-The probable Origin of the general Belief in an Evil Principle.

Superstition, the product of ignorance of causes, of the proneness to seek the solution of phenomena out of and beyond nature, and of the consequent natural but unreasoning dread of the Unknown and Invisible (ignorantly termed the supernatural), is at once universal in the extent, and various in the kinds, of its despotism. Experience and reason seem to prove that, inherent to and apparently coexistent with the human mind, it naturally originates in the constitution of bumanity: ip ignorance and uncertainty, in an instinctive doubt and fear of the Unknown. Accident may moderate its power among particular peoples and 
persons; and there are always exceptional minds whose natural temper and exercise of reason are able to free them from the servitude of a delusive imagination. For the mass of mankind, the germ of superstition, prepared to assume always a new shape and sometimes fresh vigour, is indestructible. The severest assaults are ineffectual to eradicate it: hydra-like, far from being destroyed by a seeming mortal stroke, it often raises its many-headed form with redoubled force.

It will appear more philosophic to deplore the imperfection, than to deride the folly of human nature, when the fact that the superstitious sentiment is not only a result of mere barbarism or vulgar ignorance, to be expelled of course by civilisation and knowledge, but is indigenous in the life of every man, barbarous or civilised, pagan or Christian, is fully recognised. The enlightening influence of science, as far as it extends, is irresistible; and its progress within certain limits seems sure and almost omnipotent. But it is unfortunately limited in the extent of its influence, as well as uncertain in duration; while reason enjoys a feeble reign compared with ignorance and imagination.* If it is the great

* That 'speculation has on erery subject of human enquiry three successive stages; in the first of which it tends to explain the phenomena by supernatural agencies, in the sccond by metaphysical abstractions, and in the third or final state, confines itself to ascertaining their laws of succession and similitude' (Systcm of Logic, 
office of history to teach by experience, it is never useless to examine the causes and the facts of a mischievous creed that has its roots deep in the ignorant fears of mankind; but against the recurrence of the fatal effects of fanaticism apparent in the earliest and latest records of the world, there can be no sufficient security.

Dreams, magic terrors, miracles, vitches, ghosts, portents, are some of the various forms superstition has invented and magnified to disturb the peace of society as well as of individuals. The most extravagant of these need not be sought in the remoter ages of the human race, or even in the 'dark ages' of European history: they are sufficiently evident in: the legislation and theology, as well as in the popular prejudices of the seventeenth century.

The belief in the infernal art of witcheraft is perhaps the most horrid, as it certainly is the most absurd, phenomenon in the religious history of the world-m Of the millions of victims sacrificed on the altars of religion this particular delusion can claim a considerable proportion. By a moderate computation, nine millions have been burned or hanged since the establishment of Christianity.* Prechristian antiquity

by J. S. Mill), is a generalisation of Positive Philosophy, and a theory of the Science of History, consistent probably with the progress of knowledge among philosophers, but is scarcely applicable to the mass of mankind.

* According to Dr. Sprenger (Life of Mohammed). Cicero's obser- 
experienced its tremendous power, and the prinitive faith of Christianity easily accepted and soon developed it. It was reserved, however, for the triumphant Church to display it in its greatest horrors * and if we deplore the too credulous or accommodative faith of the early militant Church or the unilluminated ignorance of paganism, we may still more indignantly denounce the cruel policy of Catholicism and the barbarous folly of Protestant theology which could deliberately punish an impossible crime. It is the reproach of Protestantism that this persecution was most furiously raging in the age that produced Newton and Locke. Compared with its atrocities even the Marian burnings appear as nothing: and it may well be doubted whether the fanatic zeal of the 'bloody Queen,' is not less contemptible than the credulous barbarity of the judges of the seventeenth century. The period 1484 (the year in which Innocent VIII. published his famous 'Witch Hammer' signally ratified 120 years later by the Act of Parliament of James I. of England) to 1680 might be characterised not improperly as the era of devilworship; and we are tempted almost to embrace the vation that there was no people either so civilised or learned, or so sarage and barbarous, that had not a belief that the future may be predicted by certain persons (De Divinatione, i.), is justified by the faith of Christendom, as well as by that of paganism; and is as true of witcheraft as it is of prophecy or divination. 
theory of Zerdusht and the Magi and conceive that Ahriman was then superior in the eternal strife; to imagine the Evil One, as in the days of the Man of $\mathrm{Uz}$, 'going to and fro in the earth, and walking up and down in it.' It is come to that at the present day, according to a more rational observer of the seventeenth century, that it is regarded as a part of religion to ascribe great wonders to the devil; and those are taxed with infidelity and perverseness who hesitate to believe what thousands relate concerning his power. Whoever does not do so is accounted an atheist because he cannot persuade himself that there are two Gods, the one good and the other evil * - an assertion which is no mere hyperbole or exaggeration of a truth: there is the certain evidence of facts as well as the concurrent testimony of various writers.

Those (comparatively few) whose reason and humanity alike revolted from a horrible dogma, loudly proclaim the prevailing prejudice. Such protests, however, were, for a long time at least, feeble and useless-helplessly overwhelmed by the irresistible torrent of public opinion. All classes of society were almost equally infected by a plague-spot that knew no distinction of class or rank. If theologians (like Bishop Jewell, one of the most esteemed divines in

* Dr. Balthazar Becker, Amsterdam, 1691, quoted in Mosheim's Institutes of Ecclesiastical History, ed. Reid. 
the Anglican Church, publicly asserting on a well known occasion at once his faith and his fears) or lawyers (like Sir Edward Coke and Judge Hale) are found unmistakably recording their undoubting conviction, they were bound, it is plain, the one class by theology, the other by legislation. Credulity of so extraordinary a kind is sufficiently surprising even in theologians ; but what is to be thought of the deliberate opinion of unbiassed writers of a recent age maintaining the possibility, if not the actual occurrence, of the facts of the belief?

The deliberate judgment of Addison, whose wit and preeminent graces of style were especially devoted to the extirpation of almost every sort of popular folly of the day, could declare: 'When I hear the relations that are made from all parts of the world, not only from Norway and Lapland, from the East and West Indies, but from every particular nation in Europe, I cannot forbear thinking that there is such an intercourse and commerce with evil spirits as that which we express by the name of witcheraft. . . . In short, when I consider the question whether there are such persons in the world as those we call witches, my mind is divided between two opposite opinions; or rather, to speak my thoughts freely, I believe in general that there is and has been such a thing as witchcraft, but at the same time can give no credit to any particular 
modern instance of it.' ${ }^{*}$ Evidence, if additional were wanted, how deference to authority and universal custom may subdue the reason and understanding. The language and decision of Addison are adopted by Sir W. Blackstone in 'Commentaries on the Laws of England,' who shelters himself behind that celebrated author's sentiment; and Gibbon informs us that 'French and English lawyers of the present age [the latter half of the last century] allow the theory but deny the practice of witchcraft -influenced doubtless by the spirit of the past legislation of their respective countries. In England the famous enactment of the subservient parliament of James I. against the crimes of sorcery, \&c., was repealed in the middle of the reign of George II., our laws sanctioning not 130 years since

* Spectator, No. 117. The sentiments of Addison on a kindred subject are very similar. Writing about the vulgar ghost creed, he adds these remarkable words: "At the same time I think a person who is thus terrified with the imagination of ghosts and spectres much more reasonable than one who, contrary to the reports of all historians, sacred and profane, ancient and modern, and to the traditions of all nations, thinks the appearance of spirits fabulous and groundless. Could not I give myself up to the general testimony of mankind, I should to the relations of particular persons who are now living, and whom I cannot distrust in other matters of fact.' Samuel Johnson (whose prejudices were equalled only by his range of knowledge) proved his faith in a well-known case, if afterwards he advanced so far as to consider the question as to the reality of 'ghosts' as undecided. Sir W. Scott, who wrote when the profound metaphysical inquiries of Hume had gained ground (it is observable), is quite sceptical. 
the popular persecution, if not the legal punishment.

The origin of witchcraft and the vulgar diabolism is to be found in the rude beginnings of the religious or superstitious feeling which, known amongst the present savage nations as Fetishism, probably prevailed almost universally in the earliest ages; while that of the sublimer magic is discovered in the religious systems of the ancient Chaldeans and Persians. Chaldea and Egypt were the first, as far as is known, to cultivate the science of magic: the former people long gave the well-known name to the professional practisers of the art. Cicero (de Divinatione) celebrates, and the Jewish prophets frequently deride, their skill in divination and their modes of incantation. The story of Daniel evidences how highly honoured and lucrative was the magical or divining faculty. The Chazdim, or Chaldeans, a priestly caste inhabiting a wide and level country, must have soon applied themselves to the study, so useful to their interests, of their brilliant expanse of heavens. By a prolonged and 'daily observation,' considerable knowledge must have been attained; but in the infancy of the science astronomy necessarily took the form of an empirical art which, under the name of astrology, engaged the serious attention and perplexed the brains of the mediæval students of science or magic (nearly synonymous terms), and which still 
survives in England in the popular almanacks. The natural objects of veneration to the inhabitants of Assyria were the glorious luminaries of the sun and moon; and if their worship of the stars and planets degenerated into many absurd fancies, believing an intimate connection and subordination of human destiny to celestial influences, it may be admitted that a religious sentiment of this kind in its primitive simplicity was more rational, or at least sublime, than most other religious systems.

It is not necessary to trace the oriental creeds of magic further than they affected modern beliefs; but in the divinities and genii of Persia are more immediately traced the spiritual existences of Jewish and Christian belief. From the Persian priests are derived both the name and the practice of magic. The Evil Principle of the Magian, of the later Jewish, and thence of the western world, originated in the system (claiming Zoroaster as its founder), which taught a duality of Gods. The philosophic lawgiver, unable to penetrate the mystery of the empire of evil and misery in the world, was convinced that there is an equal and antagonistic power to the representative of light and goodness. Hence the continued eternal contention between Ormuzd with the good spirits or genii, Amchaspands, on one side, and Ahriman with the Devs (who may represent the infernal crew of Christendom) on the other. Egypt, 
in the Mosaic and Homeric ages, seems to have attained considerable skill in magic, as well as in chymistry and astrology. As an abstruse and esoteric doctrine, it was strictly confined to the priests, or to the favoured few who were admitted to initiation. The magic excellence of the magicians, who successfully emulated the miracles of Moses, was apparently assisted by a legerdemain similar to that of the Hindu jugglers of the present day.*

In Persian theology, the shadowy idea of the devil of western Asia was wholly different from the grosser conception of Christendom. Neither the evil prin- ciple of Magianism nor the witch of Palestine has much in common with the Christian. 'No contract of subjection to a diabolic power, no infernal stamp or sign of such a fatal league, no revellings of Satan and his hags, $\nmid$ no such materialistic notions could be conformable to the spirit of Judaism or at least of Magianism. It is not difficult to find the cause of this essential dissimilarity. A simple unity was severely inculcated by the religion and laws of Moses, which permitted little exercise of the imagination: while the Magi were equally severe against idolatrous forms. A monstrous idea, like that of 'Satan and his hags,' was impossible to them. Christianity, the

* The names of two of these magicians, Jannes and Jambres, have been preserved by revelation or tradition.

+ Sir W. Scott, Letters on Demonology. 
religion of the West, has received its corporeal ideas of demonology from the divinities and demons of heathenism. The Satyri and Fauni of Greece and Rome have suggested in part the form, and perhaps some of the characteristics, of the vulgar Christian devil. A knowledge of the arts of magic among the Jews was probably derived from their Egyptian life, while the Bedouins of Arabia and Syria (kindred peoples) may have instilled the less scientific rites of Fetishism. It is in the early accounts of that people that sorcery, whatever its character and profession, with the allied arts of divination, necromancy, incantations, \&c., appears most flourishing. The Mosaic penalty, 'Thou shalt not suffer a witch to live,' and the comprehensive injunction, "There shall not be found among you that maketh his son or his daughter to pass through the fire, or that useth divination, or an observer of times, or an enchanter, or a witch, or a charmer, or a consulter with familiar spirits, or a wizard, or a necromancer,' indicate at once the extent and the horror of the practice. Balaam (that equivocal prophet), on the border-land of Arabia and Palestine, was courted and dreaded as a wizard who could perplex whole armies by means of spells. His fame extended far and wide; he was summoned from his home beyond the Euphrates in the mountains of Mesopotamia by the Syrian tribes to repel the invading enemy. This great magician 
was, it seems, universally regarded as 'the rival and the possible conqueror of Moses.' *

- About the time when the priestly caste had to yield to a profane monarchy, the forbidden practices were so notorious and the evil was of such magnitude, that the newly-elected prince ' ejected' (as Josephus relates) 'the fortune-tellers, necromancers, and all such as exercised the like arts.' His interview with the witch has some resemblance to modern diablerie in the circumstances. Reginald Scot's rationalistic interpretation of this scene may be recommended to the commentating critics who have been so much at a loss to explain it. He derides the received opinion of the woman of Endor being an agent of the cevil, and ignoring any mystery, believes, ' This Pythonist being a ventriloqua, that is, speaking as it were from the bottom of her belly, did cast herself into a trance and so abused Saul, answering to Saul in Samuel's name in her counterfeit hollow voice. $\dagger$ An institution very popular with the Jews of the first temple, often commemorated in their scriptures-the schools of the prophets-was (it is not improbable) of the same kind

* Dean Stanley's Lectures on the Jewish Church.

+ Discoverie of Witchcraft, lib. viii. chap. 12. The contrivance of this illusion was possibly like that at Delphi, where in the centre of the temple was a chasm, from which arose an intoxicating smoke, when the priestess was to announce divine revelations. Seated over the chasm upon the tripod, the Pythia was inspired, it seems, by the soporific and maddening drugs. 
as the schools of Salamanca and Salerno in the middle ages, where magic was publicly taught as an abstruse and useful science; and when Jehu justifies his conduct towards the queen-mother by bringing a charge of witchcraft, he only anticipates an expedient common and successful in Europe in the sixteenth and seventeenth centuries. A Jewish prophet asserts of the Babylonian kings, that they were diligent cultivators of the arts, reproaching them with practising against the holy city.

Yet if we may credit the national historian (not to mention the common traditions), the Chaldean monarch might have justly envied, if he could scarcely hope to emulate, the excellence of a former prince of his now obscure province. Josephus says of Solomon that, amongst other attainments, 'God enabled him to learn that skill which expels demons, which is a science useful and sanative to men. He composed such incantations also by which distempers are alleviated, and he left behind him the manner of using exorcisms by which they drive away demons so that they never return.'* The story of Daniel is well known. In the captivity of the two tribes carried away into an honourable servitude he soon rose into the highest favour, because, as we are informed, he excelled in a divination that surpassed all the art of the Chaldeans, themselves

* Antiquities, book riii. 2. Whiston's transl. 
so famous for it. The inspired Jew had divined a dream or vision which puzzled 'the magicians, and the astrologers, and the sorcerers, and the Chaldeans,' and immediately was rewarded with the greatest gift at the disposal of a capricious despot. Most of the apologetic writers on witchcraft, in particular the authors of the 'Malleus'Maleficarum,' accept the assertion of the author of the history of Daniel that Nebuchadnezzar was ' driven from men, and did eat grass as oxen,' in its apparent sense, expounding it as plainly declaring that he was corporeally metamorphosed into an ox, just as the companions of Ulysses were transformed into swine by the Circean sorceries.

The Jewish ideas of good or at least evil spirits or angels were acquired during their forced residence in Babylon, whether under Assyrian or Persian government. At least 'Satan' is first discovered unmistakably in a personal form in the poem of Job, a work pronounced by critics to have been composed after the restoration. In the Mosaic cosmogony and legislation, the writer introduces not, expressly or impliedly, the existence of an evil principle, unless the serpent of the Paradisaic account, which has been rather arbitrarily so metamorphosed, represents it; * while the expressions in books vulgarly reputed before the conquest are at

* Some ingenious remarks on the subject of the serpent, \&c., may be found in Eastern Life, part ii. 5, by H. Martineuu. 
least doubtful. From this time forward (from the fifth century B.c.), says a German demonologist, as the Jews lived among the admirers of Zoroaster, and thus became acquainted with their doctrines, are found, partly in contradiction to the earlier views of their religion, many tenets prevailing amongst them the origin of which it is impossible to explain except by the operation of the doctrines of Zoroaster: to these belongs the general acceptance of the theory of Satan, as well as of good and bad angels.* Under Roman government or vassalage, sorceric practices, as they appear in the Christian scriptures, were much in vogue. Devils or demons, and the 'prince of the devils,' frequently appear; and the demoniacs may represent the victims of witchcraft. The Talmud, if there is any truth in the assertions of the apologists of witchcraft, commemorates many of the most virtuous Jews accused of the crime and executed by the procurator of Judea. $\dagger$ Exorcism

* Horst, quoted in Ennemoser's History of Magic. It has been often remarked as a singular phenomenon, that the 'chosen people,' so prompt in earlier periods on every occasion to idolatry and its cruel rites, after its restoration under Persian auspices, has been erer since uniformly opposed, even fiercely, to any sign contrary to the unity of the Deity. But the Magian system was equally arerse to idolatry.

+ Bishop Jewell (Apology for the Church of England) states that Christ was accused by the malice of his countrymen of being a juggler and wizard-prestigiatsr et maleficus. In the apostolic narrative and epistles, sorcery, witeheraft, \&c., are crimes frequently described and denounced. The Sadducean sect alone denied the existence of demons. 
was a very popular and lucrative profession.* Simon Magus the magician (par excellence), the impious pretender to miraculous powers, who 'bewitched the people of Samaria by his sorceries,' is celebrated by Eusebius and succeeding Christian writers as the fruitful parent of heresy and sorcery.

That witchcraft, or whatever term expresses the criminal practice, prevailed among the worshippers of Jehovah, is evident from the repeated anathemas both in their own and the Christian scriptures, not to speak of traditional legends; but the Hebrew and Greek expressions seem both to include at least the use of drugs and perhaps of poison. $\dagger$ The Jewish creed, as exposed in their scriptures, has deserved a

* The common belief of the people of Palestine in the transcendent power of exorcism is illustrated by a miracle of this sort, gravely related by Josephus. It was exhibited before Vespasian and his army. ' He [Eleazar, one of the professional class] put a ring that had a root of one of those sorts mentioned by Solomon to the nostrils of the demoniac; after which he drew out the demon through his nostrils : and when the man fell down immediately he adjured him to return into him no more, making still mention of Solomon, and reciting the incantations which he composed. And when Eleazar would demonstrate to the spectators that he had such power, he set a little way off a cup or basin full of water, and commanded the demon as he went out of the man to overturn it, and thereby to let the spectators know he had left the man.' This performance was received with contempt or credulity by the spectators according to their faith : but the credulity of the believers could hardly exceed that of a large number of educated people, who in our own generation detect in the miracles of animal magnetism, or the legerdemain of jugglers, an infernal or supernatural agency.

† Chashaph and Pharmakeia. Biblical critics are inclined, however, to accept in its strict sense the translation of the Jacobian divines. 
fame it would not otherwise have, because upon it have been founded by theologians, Catholic and Protestant, the arguments and apology for the reality of witchcraft, derived from the sacred writings, with an ingenuity only too common and successful in supporting peculiar prejudices and interests even of the most monstrous kind.*

In examining the phenomenon as it existed among the Greeks and Romans, it will be remarked that, while the Greeks seem to have mainly adopted the ideas of the East, the Roman superstition was of Italian origin. Their respective expressions for the predictive or presentient faculty (manteia and divinatio), as Cicero is careful to explain, appear to indicate its different character with those two peoples: the one being the product of a sort of madness, the other an elaborate and divine skill. Greek traditions made them believe that the magic science was brought from Egypt or Asia by their old philosophic and legislating sages. Some of the most eminent of the

'Since in the LXX.,' says Parkhurst, the lexicographer of the N.T., 'this noun [pharmakeia] and its relatives always answer to some Hebrew word that denotes some kind of their magical or conjuring tricks; and since it is too notorious to be insisted upon, that such infernal practices have always prevailed, and do still prevail in idolatrous countries, I prefer the other sense of incantation.'

* A sort of ingenuity much exercised of late by 'sober brows approring with a text' the institution of slarery: divine, according to them; the greatest evil that afflicts mankind, according to Alexander von Humboldt. See Personal Narrative. 
founders of philosophic schools were popularly accused of encouraging it. Pythagoras (it is the complaint of Plato) is said to have introduced to his countrymen an art derived from his foreign travels; a charge which recalls the names of Roger Bacon, Albertus Magnus, Galileo, and others, who had to pay the penalty of a premature knowledge by the suspicion of their cotemporaries. Xenophanes is said to be the only one of the philosophers who admitted the existence or providence of the gods, and at the same time entirely discredited divination. Of the Stoics, Panætius was the only one who ventured even to doubt. Some gave credit to one or two particular modes only, as those of dreams and frenzy; but for the most part every form of this sort of divine revelation was implicitly received.*

The science of magic proper is developed in the later schools of philosophy, in which Oriental theology or demonology was largely mixed. Apollonius of Tyana, a modern Pythagorean, is the most famous magician of antiquity. This great miracle-worker of paganism was born at the commencement of the Christian era; and it has been observed that his miracles, though quite independent of them,

* Cicero, in his second book De Divinatione, undertakes to refute the arguments of the Stoics, "the force of whose mind, being all turned to the side of morals, unbent itself in that of religion.' The divining faculty is divisible generally into the artificial and the natural. 
curiously coincide both in time and kind with the Christian.* According to his biographer Philostratus, this extraordinary man (whose travels and researches extended, we are assured, over the whole East even into India, through Greece, Italy, Spain, northern Africa, Ethiopia, \&c.) must have been in possession of a scientific knowledge which, compared with that of his cotemporaries, might be deemed almost supernatural. Extraordinary attainments suggested to him in later life to excite the awe of the vulgar by investing himself with magieal powers. Apollonius is said to have assisted Vespasian in his struggle for the throne of the Cæsars; afterwards, when accused of raising an insurrection against Domitian, and when he had given himself up voluntarily to the imperial tribunal at Rome, he escaped impending destruction by the exertion of his superhuman art.

Of the incantations, charms, and magic compounds in the practice of Greek witchcraft, numerous examples occur in the tragic and comic poetry of

* The proclamation of the birth of Apollonius to his mother by Proteus, and the incarnation of Proteus himself, the chorus of swans which sang for joy on the occasion, the casting out of devils, raising the dead, and healing the sick, the sudden appearances and disappearances of Apollonius, his adventures in the cave of Trophonius, and the sacred roice which called him at his death, to which may be added his claim as a teacher having authority to reform the world, ' cannot fail to suggest,' says a writer in the Dictionary of Greek and Roman Biography, \&c., ed. by Dr. W. Smith, 'the parallel passages in the Gospel history.' 
Greece; and the philtres, or love-charms, of Theocritus are well known. The names of Colchis, Chaldea, Assyria, Iberia, Thrace, may indicate the origin of a great part of the Hellenic sorceries. Yet, if the more honourable science may have been of foreign extraction, Hellas was not without something of the sorcery of modern Europe. The infernal goddess Hecate, of Greek celebrity, is the omnipotent patroness of her modern Christian slaves; and she presides at the witch meetings of Christendom with as much solemnity but with far greater malice. Originally of celestial rank, by a later metamorphosis connected, if not personally identical with, Persephone, the Queen of Hades, Hecate was invested with many of the characteristic attributes of a modern devil, or rather perhaps of a witch. The triple goddess, in her various shapes, wandered about at night with the souls of the dead, terrifying the trembling country people by apparitions of herself and infernal satellites, by the horrible whining and howls of her hellhounds which always announced her approach. She frequented cross-roads, tombs, and melancholy places, especially delighting in localities famous for deeds of blood and murder. The hobgoblins, the various malicious demons and spirits, who provoked the lively terrors of the mediæval peoples, had some prototypes in the fairy-land of Greece, in the Hecatean hobgoblins (like the Latin larvæ, \&c.), Empusa, 
Mormo, and other products of an affrighted imagination familiar to the students of Greek literature in the comic pages of Aristophanes.* From the earliest literary records down to the latest times of paganism as the state religion, from the times of the Homeric Circe and Ulysses (the latter has been recognised by many as a genuine wizard) to the age of Apollonius or Apuleius, magic and sorcery, as a philosophical science or as a vulgar superstition, had apparently more or less distinctly a place in the popular mythology of old Greece. But in the pagan history of neither Greece nor Rome do we read of holocausts of victims, as in Christian Europe, immolated on the altars of a horrid superstition. $\dagger$ The occasion of the composition of the treatise by Apuleius 'On Magic' is somewhat romantic. On his way to Alexandria, the philosopher, being disabled from proceeding on the journey, was hospitably received into the mansion of

* Particularly in the Batrachoi. The dread of the infernal apparition of the fierce Gorgo in Hades blanched the cheek of even muchdaring Odysseus (Od. xi. 633). The satellites of Hecate have been compared, not disadvantageously, with the monstrous guardians of hell; than whom

' Nor uglier follow the night-hag when, called

In secret, riding through the air she comes

Lured with the smell of infant blood to dance With Lapland witches-'

$\dagger$ An exceptional case, on the authority of Demosthenes, is that of a woman condemned in the year, or within a year or two, of the execution of Socrates. 
one Sicinius Pontianus. - Here, during the interesting period of his recovery, he captivated, or was captivated by, the love of his host's mother, a wealthy widow, and the lovers were soon united by marriage. Pudentilla's relatives, indignant at the loss of a much-coveted, and perhaps long-expected fortune, brought an action against Apuleius for having gained her affection by means of spells or charms. The cause was heard before the proconsul of Africa, and the apology of the accused labours to convince his judges that a widow's love might be provoked without superbuman means.*

- Gibbon observes of the Roman superstition on the authority of Petronius, that it may be inferred that it was of Italian rather than barbaric extraction. Etruria furnished the people of Romulus with the science of divination. Early in the history of the Republic the law is very explicit on the subject of witchcraft. In the decemviral code the extreme penalty is attached

* St. Augustin, in denouncing the Platonic theories of Apuleius, of the mediation and intercession of demons between gods and men, and exposing his magic heresies, takes occasion to taunt him with having evaded his just fate by not professing, like the Christian martyrs, his real faith when delivering his 'very copious and eloquent' apology (De Civitate Dei, lib. viii. 19). In the Golden Ass of the Greek romancist of the second century, who, in common with his cotemporary the great rationalist Lucian, deserves the praise of having exposed (with more wit perhaps than success) some of the most absurd prejudices of the day, his readers are entertained with stories that might pretty nearly represent the sentiments of the seventcenth century. 
to the crime of witchcraft or conjuration: 'Let him be capitally punished who shall have bewitched the fruits of the earth, or by either kind of conjuration (excantando neque incantando) shall have conjured away his neighbour's corn into his own field,' \&c., an enactment sneered at in Justinian's Institutes in Seneca's words. A rude and ignorant antiquity, repeat the lawyers of Justinian, had believed that rain and storms might be attracted or repelled by means of spells or charms, the impossibility of which has no need to be explained by any school of philosophy. A hundred and fifty years later than the legislation of the decemvirs was passed the Lex Cornelia, usually cited as directed against sorcery: but while involving possibly the more shadowy crime, it seems to have been levelled against the more 'substantial poison.' The conviction and condemnation of 170 Roman ladies for poisoning, under pretence of incantation, was the occasion and cause. Sulla, when dictator, revived this act de veneficiis et malis sacrificiis, for breach of which the penalty was 'interdiction of fire and water.' Senatorial anathemas, or even those of the prince, were ineffective to check the continually increasing abuses, which towards the end of the first century of the empire had reached an alarming height.*

* It will be observed that veneficus and maleficus are the significant terms among the Italians for the criminals. 
A general degradation of morals is often accompanied, it has been justly remarked, by a corresponding increase of the wildest credulity, and by an abject subservience to external religious rites in propitiaticn of an incensed deity. It was thus at Rome when the eloquence of Cicero, and afterwards the indignant satire of Juvenal or the calm ridicule of the philosophic Lucian,* attempted to assert the 'proper authority of reason.' To speak the truth, says Cicero, superstition has spread like a torrent over the entire globe, oppressing the minds and intellects of almost all men and seizing upon the weakness of human nature. $\dagger$ The historian of 'The Decline and Fall of the Roman Empire' justifies and illustrates this lament of the philosopher of the Republic in the particular case of witcheraft. "The nations and the sects of the Roman world admitted with equal credulity and similar abhorrence the reality of that infernal art which was able to control the eternal order of the planets, and the voluntary operations of the human mind. They dreaded the mysterious power of spells and incantations, of potent herbs and execrable rites, which could extinguish or recall life,

* If the philosophical arguments of Menippus (Nekrikoi Dialogoi) could have satisfied the interest of the priests or the ignorance of the people of after times, the infernal fires of the sixteenth and serenteenth centuries might not hare burned.

† De Divinatione, lib. ii. 
influence the passions of the soul, blast the works of creation, and extort from the reluctant demons the secrets of Futurity. They believed with the wildest inconsistency that the preternatural dominion of the the air, of earth, and of hell, was exercised from the vilest motives of malice or gain by some wrinkled hags or itinerant sorcerers who passed their obscure lives in penury and contempt. Such vain terrors disturbed the peace of society and the happiness of individuals; and the harmless flame which insensibly melted a waxen image might derive a powerful and pernicious energy from the affrighted fancy of the person whom it was maliciously designed to represent. From the infusion of those herbs which were supposed to possess a supernatural influence, it was an easy step to the case of more substantial poison; and the folly of mankind sometimes became the instrument and the mask of the most atrocious crimes. ${ }^{\text {* }}$

Latin poetry of the Augustan and succeeding period abounds with illustrations, and the witches of Horace, Ovid, and Lucan are the famous classical types. $\dagger$ Propertius has characterised the Striga as 'daring

* The History of the Decline and Fall of the Roman Empire, xxv. This description applies more to the Christian and later empires.

$\dagger$ 'The Canidia of Horace,' Gißbon pronounces, 'is a vulgar witch. The Erichtho of Lucan is tedious, disgusting, but sometimes sublime.' The love-charms of Canidia and Medea are chiefly indebted to the Pharmakeutria of Theocritus. 
enough to impose laws upon the moon bewitched by her spells ;' while Petronius makes his witch, as potent as Strepsiades' Thessalian sorceress, exclaim that the very form of the moon herself is compelled to descend from her position in the universe at her command. For the various compositions and incantations in common use, it must be sufficient to refer to the pages of the Roman poets. The forms of incantation and horrid rites of the Horatian Sagana Canidia (Epod. v. and Sat. i. 8), or the scenes described by the pompous verses of the poet of the civil war (De Bello Civili, vi.), where all nature is subservient, are of a similar kind, but more familiar, in the dramatic writings of the Elizabethan age. The darker characteristics of the practice, however, are presented in the burning declamations of Juvenal, only too faithfully exhibiting the unnatural atrocities perpetrated in the form and under the disguise of love-potions and charms. Roman ladies in factacquired considerable proficiency, worthy of a Borgia or Brinvilliers, in the art of poisoning and in the use of drugs. The reputed witch, both in ancient and modern times, very often belonged, like the Ovidian Dipsas, to the real and detestable class of panders: wrinkled hags were experienced in the arts of seduction, as well as in the employment of poison and drugs more familiar to the wealthier class (Sat. vi.). The great Satirist wrote in the latter half of the first century of 
Christianity; but even in the Augustan period such crimes were prevalentenough to make Ovidenumerate them among the universal evils introduced by the Iron age (Metamorphoses, i.). The despotic will of the princes themselves was exerted in vain; the mischief was too deep-rooted to succumb even to the decrees of the masters of the world. Nor did the divi themselves disdain to be initiated in the infernal or celestial science. Nigidius Figulus and the two Thrasylli are magical or mathematical names closely connected with the destinies of the two first imperial princes. Nigidius predicted, and perhaps promoted, the future elevation of Octavianus; and the elder Thrasyllus, the famous Rhodian astrologer, skilfully identified his fate with the life of his credulous dupe but tyrannical pupil. Thrasyllus' art is stated to have been of service in preventing the superstitioustyrant from executing several intended victims of his hatred or caprice, by making their safety the condition of his existence. The historian of the early empire tells of the incantations which could 'affect the mind and increase the disease' of Germanicus, Tiberius' nephew. 'There were discovered,' says Tacitus, ' dug up from the ground and out of the walls of the house, the remains of human corpses, charms and spells, and the name of Germanicus inscribed on leaden tablets, ashes half consumed covered with decaying matter, and other practices by which it is 
believed that souls are devoted to the deities of hell.'

In the fourth century, the first Christian emperor limited the lawful exercise of magic to the beneficial use of preserving or restoring the fruits of the earth or the health of the human body, while the practice of the noxious charms is capitally punished. The science of those, proclaims the imperial convert, who, immersed in the arts of magic, are detected either in attempts against the life and health of their fellowmen, or in charming the minds of modest persons to the practice of debauchery, is to be arenged and -punished deservedly by severest penalties. But in no sorts of criminal charges are those remedies to be . involved which are employed for the good of individuals, or are harmlessly employed in remote places to prevent premature rains, in the case of vineyards, or the injurious effects of winds and hailstorms, by which the health and good name of no one can be injured; but whose practices are of laudable use in preventing both the gifts of the Deity and the labours of men from being scattered and destroyed. $\dagger$

* Annales, ii. 69. Writing of the mathematicians and astrologers in the time of Galba, who urged the goveruor of Lusitania on the perilous path to the supreme dignity, the historian characterises them truly, in his inimitable language and style, as 'a class of persons not to be trusted by those in power, deceptive to the expectant; a class which will always be proscribed and preserved in our state.'

$\dagger$ Cod. Justinian. lib. ix. tit. 18. 
Constantine, in distinguishing between good and bad magic, between the theurgic and goetic, maintains a distinction made by the pagans-a distinction ignored in the later Christian Church, in whose system ' all demons are infernal spirits, and all commerce with them is idolatry and apostasy.' Christian zeal has accused the imperial philosopher and apostate Julian of having had recourse-not to much purpose-to many magical or necromantic rites; of cutting up the dead bodies of boys and virgins in the prescribed method ; and of raising the dead to ascertain the event of his Eastern expedition against the Persians.

Not many years after the death of Julian the Christian Empire witnessed a persecution for witchcraft that for its ferocity, if not for its folly, can be paralleled only by similar scenes in the fifteenth or seventeenth century. It began shortly after the final division of the East and West in the reigns of Valentinian and Valens, A.D. 373. The unfortunate accused were pursued with equal fury in the Eastern and Western Empires; and Rome and Antioch were the principal arenas on which the bloody tragedy was consummated. Gibbon informs us that it was occasioned by a criminal consultation, when the twentyfour letters of the alphabet were ranged round a magic tripod; a dancing ring placed in the centre pointed to the first four letters in the name of the future prince. 'The deadly and incoherent mixture 
of treason and magic, of poison and adultery, afforded infinite gradations of guilt and innocence, of excuse and aggravation, which in these proceedings appear to have been confounded by the angry or corrupt passions of the judges. They easily discovered that the degree of their industry and discernment was estimated by the imperial court according to the number of executions that were furnished from their respective tribunals. It was not without extreme reluctance that they pronounced a sentence of acquittal ; but they eagerly admitted such evidence as was stained with perjury or procured by torture to prove the most improbable charges against the most respectable characters. The progress of the inquiry continually opened new subjects of criminal prosecution; the audacious informers whose falsehood was detected retired with impunity: but the wretched victim who discovered his real or pretended accomplices was seldom permitted to receive the price of his infamy. From the extremity of Italy and Asia the young and the aged were dragged in chains to the tribunals of Rome and Antioch. Senators, matrons, and philosophers expired in ignominious and cruel tortures. The soldiers who were appointed to guard the prisons declared, with a murmur of pity and indignation, that their numbers were insufficient to oppose the flight or resistance of the multitude of captives. The wealthiest families were ruined by 
fines and confiscations; the most innocent citizens trembled for their safety: and we may form some notion of the magnitude of the evil from the extravagant assertion of an ancient writer [Ammianus Marcellinus], that in the obnoxious provinces the prisoners, the exiles, and the fugitives formed the greatest part of the inhabitants. The philosopher Maximus,' it is added, 'with some justice was involved in the charge of magic; and young Chrysostom, who had accidentally found one of the proscribed books, gave himself up for lost. $*$ *

The similarity of this to the horrible catastrophe of Arras, recorded by the chroniclers of the fifteenth century, excepting the grosser absurdities of the latter, is almost perfect. Valentinian and Valens, who seem to have emulated the atrocious fame of the Cæsarean family, with their ministers, concealed, it is probable, under the disguise of a simulated credulity the real motives of revenge and cupidity.

The Roman world, Christian and pagan, was subject to the prevailing fear. That portion of the globe, however, comprehended but a small part of the human race. The records of history are incomplete and imperfect; nor are they more confined in point of time than of extent. History is little more at any period than an imperfect account of the

* The History of the Decline and Fall of the Roman Empire, xxv. 
life of a few particular peoples. Necessarily limited almost entirely to an acquaintance with the history of that portion of the globe included in the 'Roman Empire,' we almost forget our profound ignorance of that vastly larger proportion of the earth's surface, the extra-Roman world, embracing then, as now, civilised as well as barbarous nations. The Chinese empire (the most extraordinary, perhaps, and whose antiquity far surpasses that of any known), comprehending within its limits two-thirds of the population of the globe; the refined and ingenious people of Hindustan, an immense population, in the East: in - the Western hemisphere nations in existence whose remains excited the admiration of the Spanish invaders; the various savage tribes of the African continent; the nomad populations of Northern Asia and Europe; nearly all these more or less, on the testimony of past and present observation, experienced the tremendous fears of the vulgar demonism.*

With the tribes who, in the time of Cæsar or Tacitus, inhabited the forests of Germany, and, perhaps, amongst the Scandinavians, some more elevated ideas obtained, the germ, however, of a

* It may be safely affirmed, according to a celebrated modern philosopher, that popular religions are really, in the eoneeption of their more vulgar votaries, a species of demonism. 'Primus in orbe deos fecit timor,' or, in the fuller expression of a modern, 'Fear made the devils, and weak Hope the gods.' 
degenerated popular prejudice. By all the German tribes, on the testimony of cotemporary writers, women were held in high respect, and were believed to have something even divine in their mental or spiritual faculties. 'Very many of their women they regard in the light of prophetesses, and when superstitious fear is in the ascendant, even of goddesses.' History has preserved the names of some of these Teutonic deities. Veleda, by prophetic inspiration, or by superior genius, directed the councils of her nation, and for some years successfully resisted the progress of the imperial arms.* Momentous questions of state or religion were submitted to their divine judgment, and it is not wonderful if, endowed with supernatural attributes, they, like other prophets, helped to fulfil their own predictions. The Britons and Gauls, of the Keltic race, seem to have resembled the Orientals, rather than the Teutons or Italians, in their religious systems. Long before the Romans came in contact with them the magic science is said to have been developed, and the priests, like those of India or Egypt, communicated the mysteries only to a privileged few, with circumstances of profound secrecy. Such was the excellence of the magic science of the British Druids, that Pliny (Hist. Nat. xxx.) was induced to suppose that the Magi

* Aurinia was the Latin name of another of these venerable sagæ. Tacitus, Histor. iv. 61, and Germania, viii. 
of Persia must have derived their system from Britain. For the most part the Kelts then, as in the present day, were peculiarly tenacious of a creed which it was the interest of a priestly caste to preserve. On the other hand, the looser religion of the Teuton nations, of the Scandinavians and Germans, could not find much difficulty in accepting the particular conceptions of the Southern conquerors; and the sorceric mythology of the Northern barbarians readily recognised the power of an Erichtho to control the operations of nature, to prevent or confound the course of the elements, interrupt the - influence of the sun, avert or induce tempests, to affect the passions of the soul, to fascinate or charm a cruel mistress, \&c., with all the usual necromantic rites. But if they could acknowledge the characteristics of the Italian Striga, those nations at the same time retained a proper respect for the venerated Saga-the German Hexe.

Of all the historic peoples of ancient Europe, the Scandinavians were perhaps most imbued with a persuasion of the efficacy of magic; a fact which their home and their habits sufficiently explain. In the Eddas, Odin, the leader of the immigration in the first century, and the great national lawgiver, is represented as well versed in the knowledge of that preternatural art; and the heroes of the Scandinavian legends of the tenth or twelfth century are especially am- 
bitious of initiation. The Scalds, like the Brahmins or Druids, were possessed of tremendous secrets; their runic characters were all powerful charms, whether against enemies, the injurious effects of an evil eye, or to soften the resentment of a lover.* The Northmen, with the exception of some nations of Central Europe, like the Lithuanians, who were not

* The following story exhibits the influence of witcheraft among: the followers of Odin. Towards the end of the tenth century, the dreaded Jomsburg sea-rovers had set out on one of their periodical expeditions, and were devastating with fire and sword the coast of Norway. A celebrated Norwegian Jarl, Hakon, collected all his forces, and sailed with a fleet of 150 vessels to encounter the pirates. Hakon, after trying in vain to break through the hostile line, retired with his fleet to the coast, and proceeded to consult a well-known sorceress in whom he had implicit confidence for any emergency. With some pretended reluctance the sorceress at length informed him that the rictory could be obtained ouly by the sacrifice of his son. Hakon hesitated not to offer up his only son as a propitiatory sacrifice; after which, returning to his fleet, and his accustomed post in the front ranks of the battle, he renewed the engagement. Towards evening the Jomsburg pirates were overtaken and overwhelmed by a violent storm, destroying or damaging their ships. They were convinced that they saw the witch herself seated on the prow of the Jarl's ships with clouds of missile weapons flying from the tips of her fingers, each arrow carrying a death-wound. With such of his followers as had escaped the sorceric encounter, the pirate-chief made the best of his way from the scene of destruction, declaring he had made a vow indeed to fight against men, but not against witches. A narrative not inconsistent with the reply of a warrior to an inquiry from the Saint-king Olaf, ' I am neither Christian nor pagan; my companions and I have no other religion than a just confidence in our strength, and in the good success which always attends us in war; and we are of opinion that it is all that is necessary.'-Mallet's Northern Antiquities. 
christianised until the thirteenth or fourteenth century, from their roving habits as well perhaps as from their remoteness, were among the last peoples of Europe to abandon their old creed. Urged by poverty and the hopes of plunder, the pirates of the Baltic long continued to be the terror of the European coasts ; but, without a political status, they were the common outlaws of Christendom. They were the relics of a savage life now giving way in Europe to the somewhat more civilised forms of society, continuing their indiscriminate depredations with impunity only because of the want of union and organisation among their neighbours. But they were in a transitional state: the coasts and countries they had formerly been content to ravage, they were beginning to find it their interest to colonise and cultivate. In the new interests and pursuits of civilisation and commerce, a natural disgust might have been experienced for the savage traditions of a religion whose gods and heroes were mostly personifications of war and rapine, under whose banners they had suffered the hardships, if they had enjoyed the plunder, of a piratic life. The national deities from being disregarded, must have come soon to be treated with undisguised contempt at least by the leaders: while the common people, serfs, or slaves were still immersed (as much as in Christian Europe) in a stupid superstition. 
When men's minds are thus universally unsettled and in want-a want both universal and necessary in states-of some new divine objects of worship more suited to advanced ideas and requirements, a system of religion more civilising and rational than the antiquated one, will be adopted without much difficulty, especially if it is not too exclusive. Yet the Scandinavians, were unusually tenacious of the forms of their ancestral worship; for while the Icelanders are said to have received Christianity about the beginning of the eleventh century, the people of Norway were not wholly converted until somewhat later. The halls of Valhalla must have been relinquished with a sigh in exchange for the less intelligible joys of a tranquil and insensuous paradise. An ancient Norsk law enjoins that the king and bishop, with all possible care, make inquiry after those who exercise pagan practices, employ magic arts, adore the genii of particular places, of tombs or rivers, who transport themselves by a diabolical mode of travelling through the air from place to place. In the extremity of the northern peninsula (amongst the Laplanders), where the light of science, or indeed of civilisation, has scarcely yet penetrated, witchcraft remains as flourishing as in the days of Odin; and the Laplanders at present are possibly as credulous in this respect as the old Northmen or the present tribes of Africa and the South Pacific. Before the intro- 
duction of the new religion (it is a curious fact), the Germans and Scandinavians, as well as the Jews, were acquainted with the efficacy of the rite of infant baptism. A Norsk chronicle of the twelfth century, speaking of a Norwegian nobleman who lived in the reign of Harald Harfraga, relates that he poured water on the head of his new-born son, and called him Hakon, after the name of his father. Harald himself had been baptized in the same way; and it is noted of the infant pagan St. Olaf that his mother had him baptized as soon as he was born. The Livonians observed the same ceremony; and a letter sent expressly by Pope Gregory III. to St. Boniface, the great apostle of the Germans, directs him how to act in such cases. It is probable, Mallet conjectures, that all these people might intend by such a rite to preserve their children from the sorceries and evil charms which wicked spirits might employ against them at the instant of their birth. Several nations of Asia and America have attributed such a power to ablutions of this kind; nor were the Romans without the custom, though they did not wholly confine it to new-born infants. A curious magical use of an initiatory and sacramental rite, ignorantly anticipated, it seems, by the unilluminated faith of the pagan world.

In reviewing the characteristics of sorcery which prevailed in the ancient world, it is obvious to com- 
pare the superstition as it existed in the nations of the East and West, of antiquity and of modern times. These natural or accidental differences are deducible apparently from the following causes:-(1) The essential distinction between the demonology of Orientalism - of .Brahminism, Buddhism, Magianism, Judaism, Mohammedanism-and that of the West, of paganism and of Christianity, founded on their respective idealistic and realistic tendencies. (2) The divining or necromantic faculties have been generally regarded in the East as honourable properties; whereas in the West they have been degraded into the criminal follies of an infernal compact. The magical art is a noble cultivated science prexogative of the priestly caste : witeheraft, in its striet sense, was mostly abandoned to the lowest, and, as a rule, to the oldest and ugliest of the female sex. In the one case the proficient was the master, in the other the slave, of the demons. (3) The position of the female sex in the Western world has been always very opposite to their status in the East, where women are believed to be an inferior order of beings, and therefore incapable of an art reserved for the superior endowments of the male sex. The modern witchcraft may be traced to that perhaps oldest form of religious conception, Fetishism, which still prevails in its utmost horrors amongst the savage peoples in different parts of the world. The early practice of magic 
was not dishonourable in its origin, closely connected as it was with the study of natural science-with astronomy and chymistry.

The magic system-interesting to us as having influenced the later Jewish creed and mediately the Christian-referred like most developed creeds to a particular founder, Zerdusht (Zarathustra of the Zend), may have thus originated. Mankind, in seeking a solution for that most interesting but unsatisfactory problem, the cause of the predominance of evil on the earth, were obliged by their ignorance and their fears to imagine, in addition . to the idea of a single supreme existence, the author and source of good, an antagonistic influence - the source and representative of evil. Physical phenomena of every day experience; the alternations of light and darkness, of sunshine and clouds; the changes and oppositions in the outer world, would readily supply an analogy to the moral world. Thus the dawn and the sun, darkness and storms, in the wondering mind of the earlier inhabitants of the globe, may have soon assumed the substantial forms of personal and contending deities.* Such seems to

* The despotism of language and its immense influence on the destiny, as well as on the various opinions, of mankind, is well shown by Professor Max Müller. 'From one point of riew,' he declares, ' the true history of religion would be neither more nor less than an account of the various attempts at expressing the Inexpressible' (Lecturcs on the Science of Language, Second Series). The witch- 
be the origin of the personifications in the Vedic hymns of Indra and Vritra with their subordinate ministers (the Ormuzd and Ahriman, \&c., of the Zend-Avesta), and of the first religious conceptions of other peoples. After this attempt to reconcile the contradictions, the irregularities of nature, by establishing a duality of gods whose respective provinces are the happiness and unhappiness of the human race, the step was easy to the conviction of the superior activity of a malignant god. The benevolent but epicurean security of the first deity might seem to have little concern in defeating or preventing the malicious schemes of the other. All the infernal apparatus of later ages was easy to be supplied by a delusive and an unreasoning imagination.

ereed may be indirectly referred, like many other absurdities, to the perversion of language, 


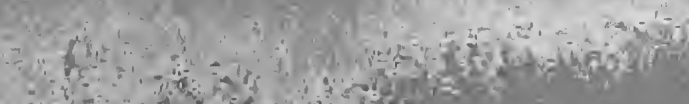

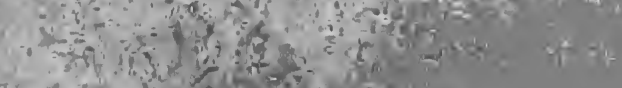

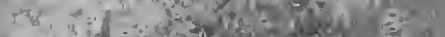

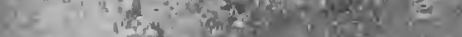

$-12 \div 8$

$4 x^{2}=5$

iignise $\quad=1$

कितो $=0$

(x)

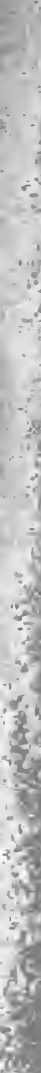




\section{PART II.}

MEDIAVAL FAITH. 


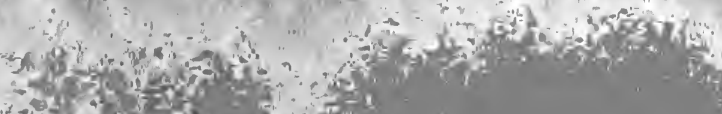
$20+-5=0$

3. of

(a)

if

$3 \%$

tex

‥ nes

$x^{2}=1-2^{2}=$

2द

70

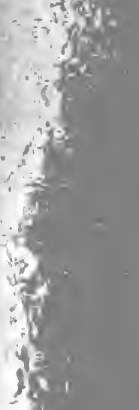




\section{CHAPTER I.}

Compromise between the New and the Old Faiths-Witcheraft under the Early Church-The Sentiments of the Fathers and the Decrees of Councils-Platonic Influences-Historical, Physiological, and Accidental Causes of the Attribution of Witcheraft to the Female Sex-Opinions of the Fathers and other Writers-The Witch-Compact.

Ir might appear, in a casual or careless observation, surprising that Christianity, whose original spirit, if not universal practice, was to enlighten; whose professed mission was 'to destroy the works of the devil,' failed to disprove as well as to dispel some of the most pernicious beliefs of the pagan world: that its final triumph within the limits of the Roman empire, or as far as it extended without, was not attended by the extinction of at least the most revolting practices of superstition. Experience, and a more extended view of the progress of human ideas, will teach that the growth of religious perception is fitful and gradual: that the education of collective mankind proceeds in the same way as that of the individual man. And thus, in the expression of the 
biographer of Charles V., the barbarous nations when converted to Christianity changed the object, not the spirit, of their religious worship. Many of the ideas of the old religion were consciously tolerated by the first propagators of Christianity, who justly deemed that the new dogmas would be more readily insinuated into the rude and simple minds of their neophytes, if not too strictly uncompromising. Both past and present facts testify to this compromise. It was a maxim with some of the early promoters of the Christian cause, to do as little violence as possible to existing prejudices*-a judicious method still pursued by the Catholic, though condemned by the Protestant, missionaries of the present day. $\dagger$ It was not seldom that an entire nation was converted and

* The remark of a late Professor of Dirinity in the University of Cambridge. 'The heathen temples,' says Professor Blunt, 'became Christian churches; the altars of the gods altars of the saints; the curtains, incense, tapers, and rotive-tablets remained the same; the aquaminarium was still the ressel for holy water; St. Peter stood at the gate instead of Cardea ; St. Rocque or St. Sebastian in the bedroom instead of the Phrygian Penates; St. Nicholas was the sign of the vessel instead of Castor and Pollux; the Mater Deûm became the Madonna ; alms pro Matre Deum became alns for the Madonna; the festival of the Mater Deûm the festival of the Madonna, or Lady Day; the Hostia or victim was now the Host; the "Lugentes Campi," or disinal regions, Purgatory; the offerings to the Manes were masses for the dead.' The parallel, he rentures to assert, might be druwn out to a far grester extent, \&e.

† Conformably to this plan, the first proselytisers in Germany and the North were often reduced (we are told) to substituting the name of Christ and the saints for those of Odin and the gods in the toasts drunk at their bacehanalian festirals. 
christianised by baptism almost in a single day: the mass of the people accepting, or rather acquiescing in, the arguments of the missionaries in submission to the will or example of their prince, whose conduct they followed as they would have followed him into the field. Such was the case at the conrersion of the Frankish chief Clovis, and of the Saxon Ethelbert. But if St. Augustin or St. Boniface, and the earlier missionaries, had more success in persuading the simple faith of the Germans, without a written rerelation and miracles, than the modern emissaries have in inducing the Hindus to abandon their Vedas, it was easier to convince them of the facts, than of the reason, of their faith. Nor was it to be expected that such raw recruits (if the expression may be allowed) should lay aside altogether prejudices with which they were imbued from infancy.

The extent of the credit and practice of witchcraft under the Church triumphant is evident from the numerous decrees and anathemas of the Church in council, which, while oftener treating it as a dread reality, has sometimes ventured to contemu or to affect to contemn it as imposture and delusion. Both the civil and ecclesiastical laws were exceptionally severe towards goetic practices. 'In all those laws of the Christian emperors,' says Bingham, 'which granted indulgences to criminals at the Easter festival, the venefici and the malefici, that is, magical 
practices against the lives of men, are always excepted as guilty of too heinous a crime to be comprised within the general pardon granted to other offenders.' * In earlier ecclesiastical history, successive councils or synods are much concerned in fulminating against them. The council of Ancyra (314) prohibits the art under the name of pharmacy : a few years' penance being appointed for anyone receiving a magician into his house. St. Basil's canons, more severe, appoint thirty years as the necessary atonement. Divination by lots or by consulting their sacred scriptures, just as afterwards they consulted Virgil, seems to have been a very favourite mode of discovering the future. The clergy encouraged and traded upon this kind of divination: in the Gallican church it was notorious. 'Some reckon,' the pious author of the 'Antiquities of the Christian Church' informs us, 'St. Augustin's conversion owing to such a sort of consultation; but the thought is a great mistake, and very injurious to him, for his conversion was owing to a providential call, like that of St. Paul, from heaven.' And that eminent saint's confessions are quoted to prove that his conversion from the depths of vice and licentiousness to the austere sobriety of his new faith, was indebted to a legitimate use of the scriptures. St. Chrysostom upbraids his cotemporaries for exposing the faith, by their illegiti*. Bingham's Origines Ecclcsiastice, xri. 
mate inquiries, to the scorn of the heathen, many of whom where wiser than to hearken to any such fond impostures.

St. Augustin complains that Satan's instruments, professing the exercise of these arts, were used to 'set the name of Christ before their ligatures, and enchantments, and other devices, to seduce Christians to take the venomous bait under the covert of a sweet and honey potion, that the bitter might be hid under the sweet, and make men drink it without discerning to their destruction.' The heretics of the primitive, as well as of the middle, ages were accused of working miracles, and propagating their accursed doctrines by magical or infernal art. Tertullian, and after him Eusebius, denounce the arch-heretic Simon Magus for performing his spurious miracles in that way: and Irenæus had declared of the heretic Marcus, that when he would consecrate the eucharist in a cup of wine and water, by one of his juggling tricks, he made it appear of a purple and red colour, as if by a long prayer of invocation, that it might be thought the grace from above distilled the blood into the cup by his invocation. A correspondent of Cyprian, the celebrated African bishop, describes a woman who pretended 'to be inspired by the Holy Ghost, but was really acted on by a diabolical spirit, by which she counterfeited ecstasies, and pretended to prophesy, and wrought many wonderful and 
strange things, and boasted she would cause the earth to move. Not that the devil [he is cautious to affirm] has so great a power either to move the earth or shake the elements by his command; but the wicked spirit, foreseeing and understanding that there will be an earthquake, pretends to do that which he foresees will shortly come to pass. And by these lies and boastings, the devil subdued the minds of many to obey and follow him whithersoever he would lead them. And he made that woman walk barefoot through the snow in the depth of winter, and feel no trouble nor harm by running about in that fashion. But at last, after having played many such pranks, one of the exorcists of the Church discovered her to be a cheat, and showed that to be a wicked spirit which before was thought to be the Holy Ghost.'*

Christian witcheraft was of a more tremendous nature than even that of older times, both in its origin and practice. The devils of Christianity were the metamorphosed deities of the old religions. The Christian convert was convinced, and the Fathers of the Church gravely insisted upon the fact, that the oracles of Delphi or Dodona had been inspired in the

* Origines Ecclesiastice, xvi. The exorcists were a recognised and respectable order in the Church. See id. iii. for an account of the Energumenoi or demoniacs. The lawyer Ulpian, in the time of Tertullian, mentions the Order of Exorcists as well known. St. Augustin (De Civit. Dei, xxii. 8) records some extraordinary cures on his own testimony within his diocess of Hippo. 
times of ignorance and idolatry by the great Enemy, who used the priest or priestess as the means of accomplishing his eternal schemes of malice and mischief. At the instant, however (so it was confidently affirmed), of the divine incarnation the oracular temples were closed for ever; and the demons were no longer permitted to delude mankind by impersonating pagan deities. They must now find some other means of effecting their fixed purpose. It was not far to seek. There were human beings who, by a preeminently wicked disposition, or in hope of some temporary profit, were prepared to risk their future prospects, willing to devote both soul and body to the service of hell. The 'Fathers' and great expounders of Christianity, by their sentiments, their writings, and their claims to the miraculous powers of exoreising, greatly assisted to advance the common opinions. Justin Martyr, Origen, Tertullian, Jerome, were convinced that they were in perpetual conflict with the disappointed demons of the old world, who had inspired the oracles and usurped the worship of the true God. Nor was the contest always merely spiritual: they engaged personally and corporeally. St. Jerome, like St. Dunstan in the tenth, or Luther in the sixteenth century, had to fight with an incarnate demon.

Exorcism-the magical or miraculous ejection of evil spirits by a solemn form of adjuration-was a 
universal mode of asserting the superior authority of the orthodox Church against the spurious pretensions of heretics.*

Christian theology in the first age even was considerably indebted to the Platonic doctrines as taught in the Alexandrian school; and demonology in the third century received considerable accessions from the speculations of Neo-Platonism, the reconciling medium between Greek and Oriental philosophy. PhiloJudæus (whose reconciling theories, displayed in his attempt to prove the derivation of Greek religious or philosophical ideas from those of Moses, have been ingeniously imitated by a crowd of modern followers) had been the first to undertake to adapt the Jewish theology to Greek philosophy. Plotinus and Porphyrius, the founders of the new school of Platonism, introduced a large number of angels or demons to the acquaintance of their Christian fellow-subjects in the third century. $\dagger$ It has been remarked that 'such

* The art of expelling demons, indeed, has been preserved in the Protestant section of the Christian Church until a recent age. The exorcising power, it is remarkable, is the sole claim to miraculous privilege of the Protestants. The formula de Strumosis Attrectandis, or the form of touching for the king's evil (a similar claim), was one of the recognised offices of the English Established Church in the time of Queen Anne, or of George I.

+ 'The knowledge that is suited to our situation and powers, the whole compass of moral, natural, and mathematical science, was negleeted by the new Platonists; whilst they exhausted their strength in the rerbal disputes of metaphysies, they attempted to explore the secrets of the invisible world, and studied to reconcile Aristotle with 
was the mild spirit of antiquity that the nations were less attentive to the difference than to the resemblance of their religious worship. The Greek, the Roman, and the barbarian, as they met before their respective altars, easily persuaded themselves that, under various names and with various ceremonies, they adored the same deities.* Magianism and Judaism, however, were little imbued with the spirit of toleration; and the purer the form of religious worship, the fiercer, too often, seems to be the persecution of differing creeds. Christianity, with something of the spirit of Judaism from which it sprung, was forced to believe that the older religions must have sprung from a diabolic origin. The whole pagan world was inspired and dominated by wicked spirits. 'The pagans deified, the Christians diabolised, Nature.' $\dagger$ It is in this fact that the entirely opposite

Plato on subjects of which both these philosophers were as ignorant as the rest of mankind. Consuming their reason in those deep but unsubstantial meditations, their minds were exposed to illusions of fancy. They flattered themselves that they possessed the secret of disengaging the soul from its corporeal prison; claimed a familiar intercourse with demons and spirits; and by a very singular revolution, converted the study of philosophy into that of magic.'-The Decline and Fall of the Roman Empire, chap. xiii.

* The Egyptians, almost the only exception to polytheistic tolerance, seem to have been rendered intolerant by the number of antagonistic animal-gods worshipped in different parts of the country, enumerated by Juvenal, who describes the effects of religious animosity displayed in a faction fight between Ombi or Coptos and Tentyra._Sat. xv.

† Life of Goethe, by G. H. Lewes. . 
spirit of antique and mediæval thought, evident in the life, literature, in the common ideas of ancient and mediæval Europe, is discoverable.

The female sex has been always most concerned in the crime of Christian witchcraft. What was the cause of this general addiction, in the popular belief, of that sex, it is interesting to inquire. In the East now, and in Greece of the age of Simonides or Euripides, or at least in the Ionic States, women are an inferior order of beings, not only on account of their weaker natural faculties and social position, but also in respect of their natural inclination to every sort of wickedness. And if they did not act the part of a Christian witch, they were skilled in the practice of toxicology. With the Latin race and many European peoples, the female sex held a better position; and it may appear inconsistent that in Christendom, where the Goddess-Mother was almost the higheșt object of veneration, woman should be degraded into a slave of Satan. By the northern nations they were supposed to be gifted with supernatural power; and the universal powers of the Italian hag have been already noticed. But the Church, which allowed no miracle to be legitimate out of the pale, and yet could not deny the fact of the miraculous without, was obliged to assert it to be of diabolic origin. Thus the priestess of antiquity became a witch. This is the historical account. Physically, the cause seems discoverable in 
the fact that the natural constitution of women renders their imaginative organs more excitable for the ecstatic conditions of the prophetic or necromantic arts. On all occasions of religious or other cerebral excitement, women (it is a matter of experience) are generally most easily reduced to the requisite state for the expected supernatural visitation. Their hysterical (hystera) natures are sufficiently indicative of the-origin of such hallucinations. Their magical or pharmaceutical attributes might be derived from savage life, where the men are almost exclusively occupied either in war or in the chase: everything unconnected with these active or necessary pursuits is despised as unbecoming the superior nature of the male sex. To the female portion of the community are abandoned domestic employments, preparation of food, the selection and mixture of medicinal herbs, and all the mysteries of the medical art. How important occupations like these, by ignorance and interest, might be raised into something more than natural skill, is easy to be conjectured. That so extraordinary an attribute would often be abused is agreeable to experience.*

According to the earlier Christian writers, the frailer sex is addicted to infernal practices by reason

* Quintilian declared, 'Latrocinium facilius in riro, veneficium in feminâ credam.' To the same effect is an observation of Pliny: 'Scientiam feminarum in veneficiis præralere.' 
of their innate wickedness : and in the opinion of the ' old Fathers' they are fitted by a corrupt disposition to be the recipients and agents of the devil's will upon earth. The authors of the Witch-Hammer have supported their assertions of the proneness of women to evil in general, and to sorcery in particular, by the respectable names and authority of St. Chrysostom, Augustin, Dionysius Areopagiticus, Hilary, \&c. \&c.* The Golden-mouthed is adduced as especially hostile in his judgment of the sex ; and his ' Homily on Herodias' takes its proper place with the satires of Aristophanes and Jurenal, of Boccaccio and Boileau. $\dagger$

Reginald Scot gives the reasons alleged by the apologists of witchcraft. 'This gift and natural influence of fascination may be increased in man according to his affections and perturbations, as through anger, fear, love, hate, \&c. For by hate, saith Varius, entereth a fiery inflammation into the eye of man, which being violently sent out by beams

'They style a wifo

The dear-bought curse and lawful plague of life,

A bosom-serpent and a domestic evil.'

$\uparrow$ The royal author of the Demonologie finds no difficulty in accounting for the vastly larger proportion of the female sex deroted to the deril's service. 'The reason is easy,' he declares; ' for as that sex is frailer than man is, so is it easier to be entrapped in the gross snares of the devil, as was over-well proved to be true by the serpent's deceiving of Era at the beginning, which makes him the homelier with that sex sensine:' and it is profoundly observed that witches cannot eren shed teurs, though women in general are, like the crocodile, ready to weep on every light occasion. 
and streams infect and bewitch those bodies against whom they are opposed. And therefore (he saith) that is the cause that women are oftener found to be witches than men. For they have such an unbridled force of fury and concupiscence naturally, that by no means is it possible for them to temper or moderate the same. So as upon every trifling occasion they, like unto the beasts, fix their furious eyes upon the party whom they bewitch. . . . Women also (saith he) are oftenlie filled full of superfluous humours, and with them the melancholike blood boileth, whereof spring vapours, and are carried up and conveyed through the nostrils and mouth, to the bewitching of whatsoever it meeteth. For they belch up a certain breath wherewith they bewitch whomsoever they list. And of all other women lean, hollow-eyed, old, beetle-browed women (saith he) are the most infectious. "* Why old women are selected as the most proper means of doing the devil's will may be discovered in their peculiar characteristics. The repulsive features, moroseness, avarice, malice, garrulity of his hags are said to be

* Discoverie of Witchcraft, book xii. 21.-We shall have occasion hereafter to notice this great opponent of the devil's regime in the sixteenth century. We may be inclined to consider a more probable reason-that spirits, being in the general belief (so Adam infers that God had 'peopled highest heaven with spirits masculine') of the masculine gender, the recipients of their inspiration are naturally of the other sex : evil spirits could propagate their human or half-human agents with least suspicion and in the most natural way. 
appropriate instruments. Scotinforms us, 'One sort of such as are said to be witches are women which be commonly old, lame, blear-eyed, pale, foul, and full of wrinkles, poor, sullen, superstitious, and papists, or such as know no religion, in whose drowsy minds the devil hath got "a fine seat. They are lean and deformed, showing melancholy in their faces, to the horror of all that see them. They are doting, scolds, mad, devilish . . . neither obtaining for their service and pains, nor yet by their art, nor yet at the devil's hands, with whom they are said to make a perfect visible bargain, either beauty, money, pro'motion, wealth, worship, pleasure, honour, knowledge, or any other benefit whatsoever.' As to the preternatural gifts of these hags, he sensibly argues: 'Alas! what an unapt instrument is a toothless, old, impotent, unwieldy woman to fly in the air; truly, the devil little needs such instruments to bring his purposes to pass.*

Dr. Glanvil, who wrote in the latter half of the seventeenth century, and is bitterly opposed to the 'Witch-Advocate' and his followers, defends the capabilities of hags and the like for serving the demons. He conjectures, 'Peradventure 'tis one of

* Discoverie, i. 3, 6.-Old women, however, may be negatively useful. One of the writers on the subject (John Nider) reeommends them to young men since 'Vetularum aspectus et colloquia amorem excutiunt.' 
the great designs, as 'tis certainly the interest, of those wicked agents and machinators industriously to hide from us their influences and ways of acting, and to work as near as 'tis possible incognito; upon which supposal it is easy to conceive a reason why they most commonly work by and upon the weak and the ignorant, who can make no cunning observations or tell credible tales to detect their artifice.* The act of bewitching is defined to be 'a supernatural work contrived between a corporal old woman and a spiritual devil' ('Discoverie,' vi. 2). The method of initiation is, according to a writer on the subject, as follows: A decrepit, superannuated, old woman is tempted by a man in black to sign a contract to become his, both soul and body. On the conclusion of the agreement (about which there was much cheating and haggling), he gives her a piece of money, and causes her to write her name and make her mark on a slip of parchment with her own blood. Sometimes on this occasion also the witch uses the ceremony of putting one hand to the sole of her foot and the other to the crown of her head. On departing he delivers to her an imp or familiar. The familiar, in shape of a cat, a mole, miller-fly, or some other insect or animal, at stated times of the day sucks her blood through teats in different parts of

* Sadducismus Triumphatus, part i. sect. 8. 
her body.* If, however, the proper vulgar witch is an old woman, the younger and fairer of the sex were not by any means exempt from the crime. Young and beautiful women, children of tender years, have been committed to the rack and to the stake on the same accusation which condemned the old and the ugly.

* Grose's Antiquities, in Brand's Popular Antiquities of Great Britain. 


\section{CHAPTER II.}

Charlemagne's Severity-Anglo-Saxon Superstition-Norman and Arabic Magic-Influence of Arabic Science-Mohammedan Belief in Magic-Rabbinical Learning-Roger Bacon-The Persecution of the Templars-Alice Kyteler.

Tremendous as was the power of the witch in earlier Christendom, it was not yet degraded into the thoroughly diabolistic character of her more recent successors. Diabolism advanced in the same proportion with the authority of the Church and the ignorant submission of the people. In the civil law, the Emperor Leo, in the sixth century, abrogated the Constantinian edict as too indulgent or too credulous : from that time all sorts of charms, all use of them, beneficial or injurious, were declared worthy of punishment. The different states of Europe, founded on the ruins of the Western Empire, more or less were engaged in providing against the evil consequences of sorcery. Charlemagne pursued the criminals with great severity. He ' had several times given orders that all necromancers, astrologers, and witches should be driven from his states; but as the 
number of criminals augmented daily, he found it necessary at last to resort to severer measures. In consequence, he published several edicts, which may be found at length in the "Capitulaire de Baluse." By these every sort of magic, enchantment, and witchcraft was forbidden, and the punishment of death decreed against those who in any way evoked the devil, compounded love-philters, afflicted either man or woman with barrenness, troubled the atmosphere, excited tempests, destroyed the fruits of the earth, dried up the milk of cows, or tormented their fellow-creatures with sores and diseases. All persons found guilty of exercising these execrable arts were to be executed immediately upon conviction, that the earth might be rid of the curse and burden of their presence; and those who consulted them might also be punished with death.**

The Saxons, in the fifth century, imported into Britain the pagan forms of the Fatherland; and the Anglo-Saxon (Christian) laws are usually directed against practices connected with heathen worship, of which many reminiscences were long preserved. Their Hexe, or witch, $\uparrow$ appears to be half-divine,

* M. Garinet's Histoire de la Magic en France, quoted in Memoirs of Extraordinary Popular Delusions.

† The Saxon 'witch' is derived, apparently, from the rerb 'to weet,' to know, be wise. The Latin 'saga' is similarly derived'Sagire, sentire acute est: ex quo sage anus, quia multa scire volunt.'-Cicero, de Divinatione. 
half-diabolic, a witch-priestess who derived her inspiration as much from heavenly as from hellish sources; from some divinity or genius presiding at a sacred grove or fountain. King Athelstan is said to have made a law against witchcraft and similar acts which inflict death; that if one by them be made away, and the thing cannot be denied, such practicers shall be put to death; but if they endeavour to purge themselves, and be cast by the threefold ordeal, they shall be in prison 120 days; which ended, their kindred may redeem them by the payment [in the universal style of the English penalties] of 120 shillings to the king, and further pay to the kindred of the slain the full valuation of the party's head; and then the criminals shall also procure sureties for good behaviour for the time to come; and the Danish prince Knut denounces by an express doom the noxious acts of sorcery.* Some of the witches who appear under Saxon domination are almost as ferocious as those of the time of Bodin or of James; cutting up the bodies of the dead, especially of children, devouring their heart and liver in midnight

* A curious collection of old English superstitions in these and their allied forms, as exhibited in rarious documents, appears in a recent work of authority, entitled 'Leechdoms, Wort-Cunning, and Starcraft of Early England. Published by the authority of the Lords Commissioners of Her Majesty's Treasury, under the direction of the Master of the Rolls.' Diseases of all sorts are for the most part inflicted upon mankind by evil demons, through the agency of spells and incantations. 
revels. Fearful are the deeds of Saxon sorcery as related by the old Norman or Anglo-Norman writers. Roger of Wendover ('Flowers of History') records the terrible fate of a hag who lived in the village of Berkely, in the ninth century. The devil at the appointed hour (as in the case of Faust) punctually carries off the soul of his slave, in spite of the utmost watch and ward. These scenes are, perhaps, rather Norman than Saxon. It was a favourite belief of the ancients and mediævalists that the inhospitable regions of the remoter North were the abode of demons who held in those suitable localities their infernal revels, exciting storms and tempests: and the monk-chronicler Bede relates the northern parts of Britain were thus infested.*

From Scandinavia the Normans must have brought a conviction of the truths of magic; and although they had been long settled, before the conquest of England, in Northern France and in Christianity, the traditional glories of the land from which were de-

* Strutt derires the 'long-continued custom of swimming people suspected of witcheraft' from the Anglo-Saxon mode of judicial trial - the ordeal by water. Another 'method of proving a witch', by weighing against the Church Bible (a formidable balance), is traced to some of their ancient customs. James VI. (Demonologie) is conrineed that 'God hath appointed, for a supernatural sign of the monstrous impiety of witches, that the water shall refuse to receire them in her bosom that hare shaken off them the sacred water of baptism and wilfully refused the benefit thereof.' 
rived their name and renown could not be easily forgotten. Not long after the Conquest the Arabic learning of Spain made its way into this country, and it is possible that Christian magic, as well as science, may have been influenced by it. Magic, scientifically treated, flourished in Arabic Spain, being extensively cultivated, in connection with more real or practical learning, by the polite and scientific Arabs. The schools of Salamanca, Toledo, and other Saracenic cities were famous throughout Europe for eminence in medicine, chymistry, astronomy, and mathematics. Thither resorted the learned of the North to perfect themselves in the then cultivated branches of knowledge. The vast amount of scientific literature of the Moslems of Spain, evidenced in their public libraries, relieves Southern Europe, in part at least, from the stigma of a universal barbaric illiteracy.* Several volumes of Arabian philosophy are said to have been introduced to Northern Europe in the twelfth century;

* The royal library of the Fatimites consisted of 100,000 manuscripts, elegantly transcribed and splendidly bound, which were lent, without ararice or jealousy, to the students of Cairo. Yet this collection must appear moderate if we believe that the Ommiades of Spain had formed a library of 600,000 volumes, 44 of which were employed in the mere catalogue. Their capital, Cordora, with the adjacent towns of Malaga, Almeira, and Mureia, had giren birth to more than 300 writers; and above 70 public libraries were opened in the cities of the Andalusian kingdom. - Dicline and Fall of the Roman Empire, lii. 
and it was in the school of Toledo that Gerbert-a conspicuous name in the annals of magic-acquired his preternatural knowledge.

The few in any way acquainted with Greek literature were indebted to the Latin translations of the Arabs; while the Jewish rabbinical learning, whose more useful lore was encumbered with much mystical nonsense, enjoyed considerable reputation at this period. The most distinguished of the rabbis taught in the schools in London, York, Lincoln, Oxford, and Cambridge ; and Christendom has to confess its obligations for its first acquaintance with science to the enemies of the Cross.* The later Jewish authorities had largely developed the demonology of the subjects of Persia ; and the spiritual or demoniacal creations of the rabbinical works of the Middle Ages might be readily acceptable, if not coincident, to Christian faith. But the Western Europeans, before the philosophy of the Spanish Arabs was known, had come in contact with the Saracens and Turks of the East during frequent pilgrimages to the tomb of Christ; and the fanatical crusades of the eleventh and twelfth centuries facilitated and secured the hazardous journey. Mohammedans of the present day preserve the implicit faith of their ancestors in the efficacy of the 113th chapter of the Koran against evil spirits, the

* Chymistry and Algebra still attest our obligation by their Arabic etymology. 
spells of witches and sorcerers-a chapter said to have been revealed to the Prophet of Islam on the occasion of his having been bewitched by the daughters of a Jew. The Genii or Ginn-a Preadamite race occupying an intermediate position between angels and men, who assume at pleasure the form of men, of the lower animals, or any monstrous shape, and propagate their species like, and sometimes with, human kind-appear in imposing proportions in 'The Thousand and One Nights'- that rich display of the fancy of the Oriental imagination.*. Credulous and confused in critical perception, the crusading adventurers for religion or rapine could scarcely fail

* A common tradition is that Soliman, king of the Jews, having finally subdued-a success which he owed chiefly to his rast magical resources-the rebellious spirits, punished their disobedience by incarcerating them in various kinds of prisons, for longer or shorter periods of time, in proportion to their demerits. For the belief of the followers of Mohammed in the magic excellence of Solomon, see Sale's Koran, xxi. and xxrii. According to the prophet, the devil taught men magic and sorcery. The magic of the Moslems, or, at least, of the Egyptians, is of two kinds-high and low-which are termed respectively rahmanee (divine) and sheytanee (Satanic). By a perfect knowledge of the former it is possible to the adept to ' raise' the dead to life, kill the living, transport himself instantly wherever he pleases, and perform any other miracle. The low magic (sooflee or sheytanee) is beliered to depend on the agency of the deril and evil spirits, and unbeliering genii, and to be used for bad purposes and by bad men.' The divine is 'founded on the agency of God and of His angels, \&c., and employed always for good purposes, and only to be practised by men of probity, who, by tradition or from books, learn the names of those superhuman agents, \&c.'-Lane's Modern Egyptians, chap. xii. 
to confound with their own the peculiar tenets of an ill-understood mode of thought; and that the critical and discriminating faculties of the champions of the Cross were not of the highest order, is illustrated by their difficulty in distinguishing the eminently unitarian religion of Mohammed from paganism. By a strange perversion the Anglo-Norman and French chroniclers term the Moslems Pagans, while the Saxon heathen are dignified by the title of Saracens; and the names of Mahmoud, Termagaunt, Apollo, could be confounded without any sense of impropriety. However, or in whatever degree, Saracenic or rabbinical superstition tended to influence Christian demonology, from about the end of the thirteenth century a considerable development in the mythology of witchcraft is perceptible.*

Conspicuous in the vulgar prejudices is the suspicion attaching to the extraordinary discoveries of philosophy and science. Diabolic inspiration (as in our age infidelity and atheism are popular outcries) was a ready and successful accusation against ideas or discoveries in advance of the time. Roger Bacon,

* Its effect was probably to enlarge more than to modify appreciably the current ideas. A large proportion of the importations from the East may have been indebted to the invention, as much as to the credulity, of the adventurers; and we might be disposed to believe with Hume, that 'men returning from so great a distance used the liberty [a too general one] of imposing every fiction upon their believing audience.' 
Robert Grostête, Albert the Great, Thomas of Ercildoun, Michael Scot-eminent names-were all more or less objects of a persecuting suspicion. Bacon may justly be considered the greatest name in the philosophy of the Middle Age. That anomaly of mediævalism was one of the few who could neglect a vain and senseless theology and system of metaphysics to apply his genius to the solid pursuits of truer philosophy; and if his influence has not been so great as it might have been, it is the fault of the age rather than of the man. Condemned by the fear or jealousy of his Francisean brethren and Dominican rivals, Bacon was thrown into prison, where he was excluded from propagating 'certain suspected novelties' during fourteen years, a victim of his more liberal opinions and of theological hatred. One of the traditions of his diabolical compacts gives him credit at least for ingenuity in avoiding at once a troublesome bargain and a terrible fate. The philosopher's compact stipulated that after death his soul. was to be the reward and possession of the devil, whether he died within the church's sacred walls or without them. Finding his end approaching, that sagacious magician caused a cell to be constructed in the walls of the consecrated edifice, giving directions, which were properly carried out, for his burial in a tomb that was thus neither within nor without the church-an evasion of a long-expected event, which 
lost the disappointed devil his prize, and probably his temper. 'Friar Bacon' became afterwards a well-known character in the vulgar fables: he was the type of the mediæval, as the poet Virgil was of the ancient, magician. A popular drama was founded on his reputed exploits and character in the sixteenth century, by Robert Greene, in ' Friar Bacon and Friar Bungay;' but the famous Dr. Faustus, the most popular magic hero of that time on the stage, was a formidable rival. While his cotemporaries denounced his rational method, preferring their theological jargon and scholastic metaphysics; how much the - Aristotle of mediævalism has been neglected even latterly is a surprising fact.*

But in proof of the prevalence of the popular suspicion, not even the all-powerful spiritual Chief of Christendom was spared. Many of the pontiffs were charged with being addicted to the 'Black Art'-an odd imputation against the vicars of Christ and the șuccessors of St. Peter. A charge, however, which we may be disposed to receive as evidence that in a long and disgusting list of ambitious priests and licentious despots there have been some popes who, by cultivating philosophy, may have in some sort

* The Universities of Oxford and Cambridge hare not exhibited the same impatience for a worthy edition of the works of Bacon with which Clement IV. expected a copy of the Opus Majus. His principal writings remained in MS. and were not published to the world until the middle of last century. 
partially redeemed the hateful character of Christian sacerdotalism. At a council held at Paris in the interest of Philip IV., Boniface VIII. was publicly accused of sorcery: it was affirmed that 'he had a familiar demon [the Socratic Genius?]; for he has said that if all mankind were on one side and he alone on the other, he could not be mistaken either in point of fact or of right, which presupposes a diabolical art '-a dogma of sacerdotalism sufficiently confident, but scarcely requiring a miraculous solution. This pope's death, it is said, was hastened by these and similar reports of his dealings with familiar spirits, invented in the interest of the French king to justify his hostility. Boniface VIII.'s esoteric opinions on Catholicism and Christianity, if correctly reported, did not show the orthodoxy to be expected from the supreme pontiff: but he would not be a singular example amongst the numerous occupants of the chair of St. Peter.*

John XXII., one of his more immediate successors, is said to be the pope who first formally condemned the crime of witchcraft, more systematically anathematised some hundred and fifty years afterwards by Innocent VIII. He complains of the universal in-

* Leo X. (whose tastes were rather profane than pious) instructed or amused himself by causing to be discussed the question of the nature of the soul-himself adopting the opinion 'redit in nihilum quod fuit ante nihil,' and the decision of Aristotle and of Epicurus. 
fection of Christendom : that his own court even, and immediate attendants, were attached to the devil's service, applying to him on all occasions for help. The earliest judicial trial for the crime on record in England is said to have occurred in the reign of John. It is briefly stated in the 'Abbreviatio Placitorum' that 'Agnes, the wife of Odo the merchant, accused Gideon of sorcery; and he was acquitted by the judgment of iron.' The first account of which much information is given occurs in Edward II.'s reign, when the lives of the royal favourites, the De Spencers, and his own, were attempted by a supposed criminal, one John of Nottingham, with the assistance of his man, Robert Marshall, who became king's evidence, and charged his master with having conspired the. king's death by the arts of sorcery.* Cupidity or malice was the cause of this informer's accusation. One of the distinguishing characteristics in its annals was the abuse of the common prejudice for political purposes, or for the gratification of private passion.

At the commencement of the fourteenth century the persecution and final destruction of the Order of the Knights Templars in the different countries of Europe, but chiefly in France (an instance of the

* Narratives of Sorcery and Magic, by Thomas Wright. 
former abuse), is one of the most atrocious facts in the history of those times. The fate of the Knights of the Temple (whose original office it had been to protect their coreligionists during pilgrimages in the Holy City, and whose quarters were near the site of the Temple-whence the title of the Order): in France was determined by the jealousy or avarice of Philip IV. Founded in the first half of the twelfth century as a half-religious, half-military institution, that celebrated Order was, in its earlier career, in high repute for valour and success in fighting the battles of the Cross. With wealth and fame, pride and presumption increased to the highest pitch; and at the end of 150 years the champions of Christendom were equally hated and feared. Their entire number was no more than 1,500 ; but they were all experienced warriors, in possession of a number of important fortresses, besides landed property to the amount, throughout their whole extent, of nine thousand manorial estates. When the Holy Land was hopelessly lost to the profane ambition or religious zeal of the West, its defenders returned to their homes loaded with riches and prestige if not with unstained honour, and without insinuations that they had betrayed the cause of Christ and the Crusades. Such was the condition of the Temple when Philip, after exhausting the coffers of Jews and 
Christians, found his treasury still unfilled. The opportunity was not to be neglected: it remained only to secure the consent of the Church, and to provoke the ready credulity of the people. Church and State united, supported by the popular superstition, were irresistible; and the destined victims expected their impending fate in silent terror. At length the signal was given. Prosecutions in 1307 were carried on simultaneously throughout the provinces; but in French territory they assumed the most formidable shape. In many places they were acquitted of the gravest indictments: the English king, from a feeling of justice or jealousy, expressed himself in their favour. As for Spain, 'it was not in presence of the Moors, and on the classic ground of Crusade, that the thought could be entertained of proscribing the old defenders of Christendom.' Paris, where was their principal temple, was the centre of the Order ; their wealth and power were concentrated in France; and thus the spoils not of a single province, but almost of the entire body, were within the grasp of a single monarch. Hence he assumed the right of presiding as judge and executioner.* On

* Dante seems to refer to this recent spoliation in the following verses:-

'Lo! the new Pilate, of whose cruelty

Such violence cannot fill the measure up,

With no decree to sunction, pushes on

Into the Temple his yet eager sails.'

Purgat. xx. Cary's Transl. 
October 12, 1307, Jacques Molay, with the heads of the Temple, was invited to Paris, where, loaded with favours, they were lulled into fatal security. The delusion was soon abruptly dispelled. Molay, together with 140 of his brethren, was arrested-the signal for a more general procedure throughout the kingdom.

The charges have been resolved under three heads : (1) The denial of Christ. (2) Treachery to the cause of Christianity. (3) The worship of the devil, and the practice of soreery. The principal articles in the indictment were that the knights at initiation formally denied the divinity of Christ, pronouncing he was not truly a God-even going so far as to assert he was a false prophet, a man who had been punished for his crimes; that they had no hopes of salvation through him; that at the final reception they always spat on the Cross, trampling it under foot; that they worshipped the devil in the form of a cat, or some other familiar animal; that they adored him in the figure of an idol consecrated by anointing it with the fat of a new-born infant, the illegitimate offspring of a brother; that a demon appeared in the shape of a black or gray cat, \&c. The idol is a mysterious object. According to some it was a head with a beard, or a head with three faces: by others it was said to be a skull, a cat. One witness testified that in a chapter of the Order one brother said to 
another, 'Worship this head; it is your God and your Mahomet.' Of this kind was the general evidence of the witnesses examined. Less incredible, perhaps, is the statement that they sometimes saw demons in the appearance of women; and a more credible allegation is that of a secret understanding with the Turks.

Notoriously suspicious communication had been maintained with the enemy; they even went so far as to adopt their style of dress and living. Worse than all, by an amiable but unaccustomed tolerance, the followers of Mohammed had been allowed a free exercise of their religion, a sort of liberality little short of apostasy from the faith. Without recounting all the horrors of the persecution, it must be sufficient to repeat that fifty-four of the wretched condemned, having been degraded by the Bishop of Paris, were handed over to the flames. Four years afterwards the scene was consummated by the burnling of Jacques Molay. Torture of the most dreadful sort had been applied to force necessary confessions ; and the complaint of one of the criminals is significant - ' I, single, as I am, cannot undertake to argue with the Pope and the King of France.: * In at-

* Michelet's History of France, book r. 4. M. Michelet suggests an ingenious explanation of somn of their supposed secret practices. 'The principal charge, the denial of the Saviour, rested on an equirocation. The Templars might confess to the denial without being in reality apostates. Many averred that it was a symbolical denial, 
tempting to detect the mysterious facts of this dark transaction little assistance is given by the contradictory statements of cotemporary or later writers; some asserting the charges to be mere fabrications throughout; others their positive reality; and recent historians have attempted to substantiate or destroy them. Hallam truly remarks that the rapacious and unprincipled conduct of Philip, the submission of Clement V. to his will, the apparent incredibility of the charges from their monstrousness, the just prejudice against confessions obtained by torture and retracted afterwards ; the other prejudice, not always so just, but in the case of those not convicted on fair evidence deserving a better name, in favour of assertions of innocence made on the scaffold and at the stake, created, as they still preserve, a strong willingness to disbelieve the accusations which come so suspiciously before us.* An approximation

in imitation of St. Peter's-one of those pious comedies in which the antique Church enveloped the most serious acts of religion, but whose traditional meaning was beginning to be lost in the fourteenth century.' The idol-head, beliesed to represent Mohammed or the deril, he supposes to have been 'a representation of the Paraclete, whose festival, that of Pentecost, was the highest solemnity of the Temple.' Some have identified them, like those of the Albigenses or Waldenses, with the ceremonies of the Gnostics.

* View of the Middle Ages, chap. i. The judicial impartiality (eulogised by Macaulay) and patient investigation of truth (the first merits of a historian) of the author of the Constitutional History of England, might almost entitle him to rank with the first of historians, Gibbon. 
to the truth may be obtained if, rejecting as improbable the accusations of devil-worship and its concomitant rites which, invented to amuse the vulgar, characterise the proceedings, we admit the probability of a secret understanding with the Turks, or the possibility of infidelity to the religion of Christ. Their destruction had been predetermined; the slender element of truth might soon be exaggerated and confounded with every kind of fiction. Their pride, avarice, luxury, corrupt morals, would give colour to the most absurd inventions.*

If the history of the extermination of the Templars exemplifies in an eminent manner the political uses made by the highest in office of a prevalent superstition, the story of Alice Kyteler illustrates' equally the manner in which it was prostituted to the private purposes of designing impostors. The scene is in Ireland, the period the first half of the fourteenth century; Richard de Ledrede, Bishop of Ossory, being the principal prosecutor, and a lady, Alice Kyteler, the defendant. The details are too tedious to be repeated here; $\uparrow$ but the articles upon which the con-

* The alliance of the Church-of the Dominican Order in particular-with the secular power against its once foremost champions, is paralleled and explained by the causes that led to the dissolution of the Order of Jesus by Clement XIV. in the eighteenth century-fear and jealousy.

t They are given in full in Narratives of Sorcery and Magic from the most Authentic Sources, by Thomas Wright. In the Annals of 
viction of Alice Kyteler and her accomplices was sought are not dissimilar to those just narrated. To give effect to their sorcery they were in the habit of denying the faith for a year, or shorter period, as the object to be attained was greater or less. Demons were propitiated with sacrifices of living animals, torn limb by limb and scattered (a Hecatean feast) about cross-roads. It was alleged that by sorceries they obtained help from the devil; that they impiously used the ceremonies of the Church in nightly conventicles, pronouncing with lighted candles of wax excommunication against the persons of their own husbands, naming expressly every member from the sole of the foot to the top of the head. Their com-

Ireland, affixed to Camden's Britannia, ed. 1695, sub anno 1325 A.D., the case of Dame Alice Ketyll is briefly chronicled. Being cited and examined by the Bishop of Ossory, it was discovered, among other things, "That a certain spirit called Robin Artysson lay with her; and that she offered him nine red cocks on a stone bridge where the highway branches out into four several parts. Item: That she swept the streets of Kilkenny with besoms between Compline and Courefeu, and in sweeping the filth towards the house of William Utlaw, her son, by way of conjuring, wished that all the wealth of Kilkenny might flow thither. The accomplices of this Alice in these devilish practices were Pernil of Meth, and Basilia the daughter of this Pernil. Alice, being found guilty, was fined by the bishop, and forced to abjure her sorcery and witcheraft. But being again conricted of the same practice, she made her escape with Basilia, and was never found. But Pernil was burnt at Kilkenny, and before her death declared that William above-said deserved punishment as well as she-that for a year and a day he wore the deril's girdle about his bare body,' \&c. 
positions are of the Horatian and Shakspearian sort. With the intestines of cocks were sacrificed various herbs, the nails of dead men, hair, brains, and clothes of children dying unbaptized, with other equally efficacious ingredients, boiled in the skull of a certain famous robber recently beheaded : powders, ointments, and candles of fat boiled in the same skull were the intended instruments for exciting love or hatred, and in affecting the bodies of the faithful. An unholy connection existed between the Lady Alice and a demon in the form sometimes of a black dog, sometimes of a cat. She was possessed of a secret ointment for impregnating a piece of wood, upon which, with her companions, she was carried to any part of the world without hurt or hindrance: in her house was found a wafer of consecrated bread inscribed with the name of the devil. The event of this trial was the conviction and imprisonment of the criminals, with the important exception of the chief object of the bishop's persecution, who contrived an escape to England. Petronilla de Meath was the first to suffer the extreme penalty. This lady, by order of the bishop, had been six times flogged, when, to escape a repetition of that barbarous infliction, she made a public confession involving her fellow-prisoners. After which Petronilla was carried out into the city and burned before all the people-the first witch, it is said, ever burned in 
Ireland. Of the other accused all were treated with more or less severity; two were subsequently burned, some were publicly flogged in the market-place and through the city, others banished; a few, more fortunate, escaping altogether. 


\section{CHAPTER III.}

Witchcraft and Heresy purposely confounded by the ChurchMedixval Science closely connected with Magic and SorceryIgnorance of Physiology the Cause of many of the Popular Prejudices-Jeanne d'Arc-Duchess of Gloucester-Jane Shore -Persecution at Arras.

What can hardly fail to be discerned in these prosecutions is the confusion of heresy and sorcery industriously created by the orthodox Church to secure the punishment of her offending dissentients. There are few proceedings against the pretended criminals in which it is not discoverable; the one crime being, as a matter of course, the necessary consequence of the other. In the interest of the Church as much as in the credulity of the people must be sought the main cause of so violent an epidemic, of so fearful a phenomenon in its continuance and atrocities, a fact demonstrated by the whole course of the super"stition in the old times of Catholicism. Materials for exciting animosity and indignation against suspected heretics were near at hand. In the assuranee of the 
pre-scientific world everything remote from ordinary knowledge or experience was inseparable from supernaturalism. What surpassed the limits of a very feeble understanding, what was beyond the commonest experience of every-day life, was with one accord relegated to the domain of the supernatural, or rather to that of the devil. For what was not done or taught by Holy Church must be of 'that wicked One'-the cunning imitator.

In the twelfth century the Church was alarmed by the simultaneous springing up of various sects, which, if too hastily claimed by Protestantism as Protestants, in the modern sense, against Catholic theology, were yet sufficiently hostile or dangerous to engage the attention and to provoke the enmity of the pontiffs. The fate of the Stedingers and others in Germany, of the Paulicians in Northern France; of the Albigenses and Waldenses in Southern Europe, is in accordance with this successful sort of theological tactics. Many of the articles of indictment against those outlaws of the Church and of society are extracted from the primitive heresies, in particular from the doctrines of the anti-Judaic and spiritualising Gnostics, and their more than fifty subdivided sects -Marcionites, Manicheans, \&c. Gregory IV. issued a bull in 1232 against the Stedingers, revolted from the rule of the Archbishop of Bremen, where they are declared to be accustomed to scorn the sacraments, 
ommunion with devils, make representative es of wax, and consult with witches.* Alchymy, astrology, and kindred arts were closely allied to the practice of witchcraft : the profession of medicine was little better than the mixing of magical ointments, love-potions, elixirs, not always of an innocent sort; and Sangrados were not wanting in those days to trade upon the ignorance of their patients. $\dagger$ Nor, unfortunately, are the genuine seekers after truth who honestly applied to the study of nature exempt from the charge of often an unconscious fraud. Monstrous notions mingled with the more real results of their meritorious labours. Sciencewas in its infancy, or rather was still struggling to be freed from the oppressive weight of speculative and theological nonsense before emerging into existence." Many of the fancied phenomena of witch-cases, like other

* A second bull enters into details. On the reception of a convert, a toad made its appearance, which was adored by the assembled crowd. On sitting down to the banquet a black cat comes upon the stage, double the size of an ordinary dog, advancing backwards with up-turned tail. The neophytes, one after another, kissed this feline demon, with due solemnity, on the back. Walter Mapes has given an account of the similar ceremonies of the Publicans (Paulicians). Heretical worship was of a most licentious as well as disgusting kind. The religious meetings terminate always in indiscriminate debauchery.

† Pliny (Hist. Natur. xxx.) 'observes,' as Gibbon quotes him, 'that magic held mankind by the triple chain of religion, of physic, and of astronomy.' 
physical or mental ecentricities, have been explained by the progress of reason and knowledge. Lycanthropy (the transformation of human beings into wolves by sorcery), with the no lessirrational belief in demoniacal possession, the product of a diseased imagination and brain, was one of the many results of mere ignorance of physiology. In the seventeenth century lycanthropy was gravely defended by doctors of medicine as well as of divinity, on the authority of the story of Nebuchadnezzar, which proved undeniably the possibility of such metamorphoses.

Cotemporary annalists record the extraordinary frenzy aggravated, as it was, by the proceedings against the Templars, the signal of witch persecutions throughout France. The historian of France draws a frightful picture of the insecure condition of an ignorantly prejudiced society. Accusations poured in; poisonings, adulteries, forgeries, and, above all, charges of witchcraft, which, indeed, entered as an ingredient into all causes, forming their attraction and their horror. The judge shuddered on the judgment seat when the proofs were brought before him in the shape of philtres, amulets, frogs, black cats, and waxen images stuck full of needles. Violent curiosity was blended at these trials with the fierce joy of vengeance and a cast of fear. The public mind could not be satiated with them: the more there were burnt, the 
more there were brought to be burnt.* In 1398 the Sorbonne, at the chancellor's suggestion, published 27 articles against all sorts of sorcery, pictures of demons, and waxen figures. Six years later a synod was specially convened at Langres, and the pressing evil was anxiously deliberated at the Council of Constance.

Conspicuous about this period, by their importance and iniquity, are the cases of the Pucelle d'Orleans and the catastrophe of Arras. Incited (it is a modern conviction) by a noble enthusiasm, by her own ardent imagination, the Pucelle divested herself of the natural modesty of her sex for the dress and arms of a warrior; and 'her inexperienced mind, working day and night on the favourite object, mistook the impulses of passion for heavenly inspiration.' Reviewing the last scenes in the life of that patriotic shepherdess, we hesitate whether to stigmatise more the unscrupulous policy of the English authorities or the base subservience of the Parliament of Paris. The English Regent and the Cardinal of Winchester, unable to allege against their prisoner (the saviour of

* Michelet, whose poetic-prose may appear hardly suitable to the philosophic dignity of history, relating the fate of two knights accused with a monk of haring 'sinned' with the king's daughter-in-law ' eren on the holiest days,' and who were castrated and flayed alive, truly enough infers that ' the pious confidence of the middle age which did not mistrust the immuring of a great lady along with her knights in the precinets of a castle, of a narrow tower; the rassalage which imposed on young men as a feudal duty the sweetest cares, was a dangerous trial to human nature.' 
her country, taken prisoner in a sally from a besieged town, had been handed over by her countrymen to the foreigner) any civil crime, were forced to disguise a violation of justice and humanity in the pretence of religion; and the Bishop of Beauvais presented a petition against her, as an ecclesiastical subject, demanding to have her tried by an ecclesiastical court for soreery, impiety, idolatry, and magic. The University of Paris acquiesced. Before this tribunal the accused was brought, loaded with chains, and clothed in her military dress. It was alleged that she had carried about a standard consecrated by magical enchantments; that she had been in the habit of attending at the witches' sabbath at a fountain near the oak of Boulaincourt; that the demons had discovered to her a magical sword consecrated in the Church of St. Catherine, to which she owed her victories; that by means of sorcery she had gained the confidence of Charles VIII. Jeanne d'Arc was convicted of all these crimes, aggravated by heresy: her revelations were declared to be inventions of the devil to delude the people.*

* Shakspeare brings the fiends upon the stage: their work is done, and they now abandon the enchantress. In rain La Pucelle invokes in her extremity-

'Ye familiar spirits, that are cull'd

Out of the powerful regions under earth,

Help me this once, that France may get the field.

Oh, hold me not with silence over-long ! 
Her ecclesiastical judges then consigned their prisoner to the civil power; and, finally, in the words of Hume, "this admirable heroine-to whom the more generous superstition of the ancients would have erected altars-was, on pretence of heresy and magic, delivered over alive to the flames; and expiated by that dreadful punishment the signal services she had rendered to her prince and to her native country.'

Where I was wont to feed you with my blood

I'll lop a member off, and give it you,

In earnest of a further benefit;

So you do condescend to help me now.

Cannot my body, nor blood-sacrifice,

Entreat you to your wonted furtherance?

Then take my soul ; my body, soul, and all,

Before that England give the French the foil.

See! they forsake me.

My ancient incantations are too weak

And hell too strong for me to buckle with.'

But a worthier, if contradictory, origin is assigned for her enthusiasm when she replies to the foul aspersion of her taunting captors-

'Virtuous, and holy ; chosen from above,

By inspiration of celestial grace,

To work exceeding miracles on earth,

I never had to do with wicked spirits.

But you-that are polluted with your lusts,

'Stain'd with the guiltless blood of innocents,

Corrupt and tainted with a thousand rices-

Because you want the grace that others have,

You judge it straight a thing impossible

To compass wonders, but by help of devils.'

* History of England, xx. Shakspeare (Henry VI. part ii. act i.) has furnished us with the charms and incantations employed about 
Without detracting from the real merit of the patriotic martyr, it might be suspected that, besides her inflamed imagination, a pious and pardonable collusion was resorted to as a last desperate effort to rouse the energy of the troops or the hopes of the people-a collusion similar to that of the celebrated Constantinian Cross, or of the Holy Lance of Antioch. Every reader is acquainted with the fate of the great personages who in England were accused, politically or popularly, of the crime; and the histories of the Duchess of Gloncester and of Jane Shore are immortalised by Shakspeare. In 1417, Joan, second wife of Henry IV., had been sentenced to prison, suspected of seeking the king's death by sorcery; a certain Friar Randolf being her accomplice and agent. The Duchess of Gloucester, wife of Humphry and daughter of Lord Cobham, was an accomplice in the witchcraft of a priest and an old woman. Her associates were Sir Roger Bolingbroke, priest; Margery Jordan or Guidemar, of Eye, in Suffolk; Thomas Southwell, and Roger Only. It was asserted ' there was found in their possession a waxen image of the king, which they melted in a magical manner before a slow fire, with the intention of making Henry's force and vigour waste away by like insensible degrees.' The duchess was sentenced to do penance and to perthe same time in the case of the Duchess of Gloucester. Mother Jourdain is the representative witch-liag. 
petual imprisonment; Margery was burnt for a witch in Smithfield; the priest was hanged, declaring his employers had only desired to know of him how long the king would live; Thomas Sonthwell died the night before his execution; Roger Only was hanged, having first written a book to prove his own innocence, and against the opinion of the vulgar.* Jane Shore (whose story is familiar to all), the mistress of Edward IV., was sacrificed to the policy of Richard Duke of Gloucester, more than to any general suspicion of her guilt. Both the Archbishop of York and the Bishop of Ely were involved with the citizen's wife in demoniacal dealings, and imprisoned in the Tower. As for the ' harlot, strumpet Shore,' not being convicted, or at least condemned, for the worse crime, she was found guilty of adultery, and sentenced (a milder fate) to do penance in a white sheet before the assembled populace at St. Paul's. $\dagger$

* The historian of England justly reflects on this case that the nature of the crime, so opposite to all common sense, seems always to exempt the accusers from using the rules of common sense in their evidence.

+ This unfortunate woman was celebrated for her beanty and, with one important exception, for her virtues ; and, if her vanity could not resist the fascination of a royal lover, her power had been often, it is said, exerted in the cause of humanity. Nothwithstanding the neglect and ill-treatment experienced from the ingratitude of former fawning courtiers and people, she reached an adranced age, for she was living in the time of Sir Thomas More, who relates that "when the Protector had awhile laid unto her, for the manner sake, that she went about to bewitch him, and that she was of counsel with the lord chamberlain 
More tremendous than any of the cases above narrated is that of Arras, where numbers of all classes suffered. So transparent were the secret but real motives of the chief agitators, that even the unbounded credulity of the public could penetrate the thin disguise. The affair commenced with the accusation of a woman of Douai, called Demiselle (une femme de folle vie). Put to the torture repeatedly, this wretched woman was forced to confess she had frequented a meeting of sorcerers where several persons were seen and recognised; amongst others Jehan Levite, a painter at Arras. The chronicler of the fifteenth century relates the diabolical catastrophe thus: 'A terrible and melancholy transaction took place this year (1459) in the town of Arras, the capital of the county of Artois, which said transaction was called, I know not why, Vaudoisie: but it was said that certain men and women transported themto destroy him; in conclusion, when no colour could fasten upon this matter, then he laid heinously to her charge the thing that herself could not deny, that all the world wist was true, and that natheless every man laughed at to hear it then so suddenly so highly takenthat she was naught of her body.'-Reign of Richard III., quoted by Bishop Percy in Reliques of Old English Romance Poetry. The deformed prince fiercely attributes his proverbial misfortune to hostile witchcraft. He addresses his trembling council:

'Look how I am bewitch'd; behold mine arm Is, like a blasted sapling, wither'd up: And this is Edward's wife, that monstrous witch, Consorted with that harlot, strumpet Shore, That by their witcheraft thus have marked me.'

Richard III. act iii. se. 4. 
selves whither they pleased from the places where they were seen, by virtue of a compact with the devil. Suddenly they were carried to forests and deserts, where they found assembled great numbers of both sexes, and with them a devil in the form of a man, whose face they never saw. This devil read to them, or repeated his laws and commandments in what way they were to worship and serve him: then each person kissed his back, and he gave to them after this ceremony some little money. He then re- galed them with great plenty of meats and wines, when the lights were extinguished, and each man selected a female for amorous dalliance; and suddenly they were transported back to the places they had come from. For such criminal and mad acts many of the principal persons of the town were imprisoned; and others of the lower ranks, with women, and such as were known to be of this sect, were so terribly tormented, that some confessed matters to have happened as has been related. They likewise confessed to have seen and known many persons of rank, prelates, nobles, and governors of districts, as having been present at these meetings; such, indeed, as, upon the rumour of common fame, their judges and examiners named, and, as it were, put into their mouths: so that through the pains of the torments they accused many, and declared they had seen them at these meetings. Such as had been thus accused 
were instantly arrested, and so long and grievously tormented that they were forced to confess just whatever their judges pleased, when those of the lower rank were inhumanly burnt. Some of the richer and more powerful ransomed themselves from this disgrace by dint of money; while others of the highest orders were remonstrated with, and seduced by their examiners into confession under a promise that if they would confess, they should not suffer either in person or property. Others, again, suffered the severest torments with the utmost patience and fortitude. The judges received very large sums of money from such as were able to pay them : others fled the country, or completely proved their innocence of the charges made against them, and remained unmolested. It must not be concealed (proceeds Monstrelet) that many persons of worth knew that these charges had been raked up by a set of wicked persons to harass and disgrace some of the principal inhabitants of Arras, whom they hated with the bitterest rancour, and from avarice were eager to possess themselves of their fortunes. They at first maliciously arrested some persons deserving of punishment for their crimes, whom they had so severely tormented, holding out promises of pardon, that they forced them to accuse whomsoever they were pleased to name. This matter was considered [it must have been an exceedingly ill-devised plot to provoke suspicion and even 
indignation in such a matter] by all men of sense and virtue as most abominable: and it was thought that those who had thus destroyed and disgraced so many persons of worth would put their souls in imminent danger at the last day.' *

Meanwhile the inquisitor, Jacques Dubois, doctor in theology, dean of Nôtre Dame at Arras, ordered the arrest of Levite the artist, and made him confess he had attended the 'Vauldine;' that he had seen there many people, men and women, burghers, ecclesiastics, whose names were specified. The bishops' vicars, overwhelmed by the number and quality of the involved, began to dread the consequence, and wished to stop the proceedings. But this did not satisfy the projects of two of the most active promoters, Jacques Dubois and the Bishop of Bayrut, who urged the Comte d'Estampes to use his authority with the vicars to proceed energetically against the prisoners. Soon afterwards the matter was brought to a crisis; the fate of the tortured convicts was decided, and amidst thousands of spectators from all parts, they were brought out, each with a mitre on his head, on which was painted the devil in the form in which he appeared at the general assemblies, and burned.

* Enguerrand de Monstrelet's Chronicles, lib. iii. cap. 93, Johnes' Translation. Vaudoisie, which puzzles the annalist, seems to disclose the pretence, if not the motive, of the proceedings. Yet it is not easy to conceive so large a number of all classes involved in the proscribed heresy of the Vaudois in a single city in the north of France. 
They admitted (urder the severest torture, promises, and threats) the truth of their meetings at the sabbaths. They used a sort of ointment well known in witch-pharmacy for rubbing a small wooden rod and the palms of their hands, and by a very common mode of conveyance were borne away suddenly to the appointed rendezvous. Here their lord and master was expecting them in the shape of a goat with the face of a man and the tail of an ape. Homage was first done by his new vassals offering up their soul or some part of the body; afterwards in adoration kissing him on the back-the accustomed salutation.* Next followed the different signs and ceremonies of the infernal vassalage, in particular treading and spitting upon the cross. Then to eating and drinking; after which the guests joined in acts of indescribable debauchery, when the devil took the form alternately of either sex. Dismissal was given by a mock sermon, forbidding to go to church, hear mass, or touch holy water. All these acts indicate schismatic offences which yet for the most part are the characteristics of the sabbaths in later Protestant witchcraft, excepting that the wicked apostates are there usually papistical instead of protestant. During nearly two years Arras was subjected to the arbitrary examinations and tortures of

* The 'Osculum in tergo' seems to be an indispensable part of the Homagium or Diabolagium. 
the inquisitors; and an appeal to the Parliament of Paris could alone stop the proceedings, 1461. The chance of acquittal by the verdict of the public was little: it was still less by the sentence of judicial tribunals. 


\section{PART III.}

\section{MODERN FAITH.}

H 2 


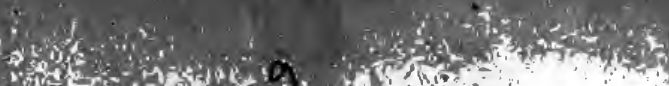

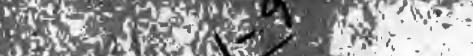

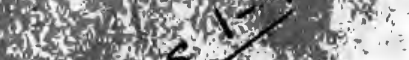

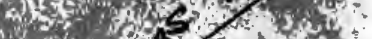

nis
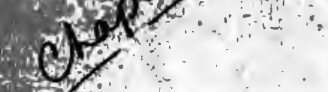

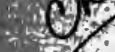

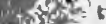

orin

$\therefore \rightarrow$

Sf:

4a:

t5:

a

स्रां:

(5),

is:

政

i.

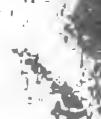

5,0

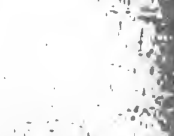

$\therefore \quad \therefore \quad \therefore \quad$

$\therefore$ वरा

$\because$ int

6. $\therefore 5$

$\therefore 4$

$\therefore \%$

$\therefore$ 


\section{CHAPTER I.}

The Bull of Innocent VIII.-A new Incentive to the rigorous Prosecution of Witcheraft - The 'Mallens Maleficarum'-Its Criminal Code-Numerous Executions at the Commencement of the Sixteenth Century-Examination of Christian Demonology-Various Opinions of the Nature of Demons-General Belief in the Intercourse of Demons and other non-human Beings with Mankind.

Perhaps the most memorable epoch in the annals of witchcraft is the date of the promulgation of the bull of Pope Innocent VIII., when its prosecution was formally sanctioned, enforced, and developed in the most explicit manner by the highest authority in the Church. It was in the year 1484 that Innocent VIII. issued his famous bull directed especially against the crime in Germany, whose inquisitors were empowered to seek out and burn the malefactors pro strigiatîs hceresi. The bull was as follows: 'Innocent, Bishop, servant of the servants of God, in order to the future memorial of the matter. . . . In truth it has come to our ears, not without immense trouble and grief to ourselves, that in some parts of Higher Germany . . . very many 
persons of both sexes, deviating from the Catholic faith, abuse themselves with the demons, Incubus and Succubus; and by incantations, charms, conjurations, and other wicked superstitions, by criminal acts and offences have caused the offspring of women and of the lower animals, the fruits of the earth, the grape, and the products of various plants, men, women, and other animals of different kinds, vineyards, meadows, pasture land, corn, and other vegetables of the earth, to perish, be oppressed, and utterly destroyed; that they torture men and women with cruel pains and torments, internal as well as external; that they hinder the proper intercourse of the sexes, and the propagation of the buman species. Moreover, they are in the habit of denying the very faith itself. We therefore, willing to provide by opportune remedies according as it falls to us by our office, by our apostolical authority, by the tenor of these presents do appoint and decree that they be convicted, imprisoned, punished, and mulcted according to their offences. ... By the apostolic rescript given at Rome.'

This, in brief, is an outline of the proclamation of Innocent VIII., the principles of which were developed in the more voluminous work of the 'Malleus Maleficarum,'* or Hammer of Witches, five years

* Ennemoser (History of Magic), a modern and milder Protestant, excepts to the general denunciations of Pope Innocent ("who assumed 
later. In the interval, the effect of so forcible an appeal from the Head of the Chureh was such as might be expected. Cumanus, one of the inquisitors in 1485, burned forty-one witches, first shaving them to seareh fer 'marks.' Alciatus, a lawyer, tells us that another ecclesiastical officer burned one hundred witches in Piedmont, and was prevented in his plan of daily autos-cla-fé only by a general uprising of the people, who at length drove him out of the country, when the archbishop succeeded to the vacant office. In several provinces, even the servile credulity of the populace could not tolerate the excesses of the judges; and the inhabitants rose en masse against their inquisitorial oppressors, dreading the entire depopulation of their neighbourhood. As a sort of apology for the bull of 1484 was published the 'Malleus'-a significantly expressive title.* The

this name, undoubtedly, because he wished it to indicate what he really desired to be') by Protestint writers who have used such terms as 'a seandalous hypocrite,' ' a cursed war-song of hell,' 'hangmen's slaves,' 'rabid jailers,' 'bloodthirsty monsters,' \&e. ; and thinks that 'the accusation whieh was made against Innocent could only have been justly founded if the pope had not participated in the general belief, if he had been wiser than his time, and really scen that the hereties were no allies of the devil, and that the witehes were no heretics.'

* The complete title is "Mralleus maleficarun in tres partes divisus, in quibus I. Coneurrentia ad malefieia; II. Maleficiorum effeetus; III. Remedia adversus maleficia. Et modus denique procedendi ac puniendi maleficas abunde continetur, preeipue autem omnibus inquisitoribus et divini verbi concionatoribus utilis et necessarins.' The original edition of 1489 is the one quoted by 
authors appointed by the pope were Jacob Sprenger, of the Order of Preachers, and Professor of Theology in Cologne; John Gremper, priest, Master in Arts; and Henry Institor. The work is divisible, according to the title, into three parts-Things that pertain to Witchcraft; The Effects of Witcheraft; and The Remedies for Witchcraft.

In this apology the editors are careful to affirm that they collected, rather than furnished, their materials originally, and give as their venerable authorities the names of Dionysius the Areopagite, Chrysostom, Hilary, Augustin, Gregory I., Remigius, Thomas Aquinas, and others. The writers exult in the consciousness of security, in spite of the attempts of the demons, day and night, to deter them from completing their meritorious labours. Stratagems of every sort are employed in vain. In their judgment the worst species of human wickedness sink into nothing, compared with apostasy from the Church and, by consequence, alliance with hell. A genuine or pretended dread of sorcery, and an affected contempt for the female sex, with an extremely low estimate of its virtues (adopting the language of the Fathers), characterises the opinions of the compilers.

Ennemoser has made an abstract from the 'Demonomagie' of Horst (founded on Hauber's original work), Hauber, Bibliotheca Mag., and referred to by Ennemoser, History of Mugic. 
of the 'Hexenhammer,' under its three principal divisions. The third part, which contains the Criminal Code, and consists of thirty-five questions, is the most important section. It is difficult to decide which is the moreiastonishing, the perfect folly or the perfect iniquity of the Code: it is easier to understand how so many thousands of victims werehelplessly sacrificed. "The arrest might take place on the simple rumour of a witch being found somewhere, without any previous denunciation. The most abandoned and the most infamous persons may be witnesses: no criminal is too bad. Even a witch or heretic (the worst criminal in the eye of ecclesiastical law) is capable of giving evidence. Husbands and wives may witness one against the other; and the testimony of children was received as good evidence.

The ninth and tenth chapters consider the question 'whether a defence was to be allowed; if an advocate defended his client beyond what was requisite, whether it was not reasonable that he too should be considered guilty; for he is a patron of witches and heretics..... Thirteenth chapter: What the judge has to notice in the torture-chamber. Witches who have given themselves up for years, body and soul, to the devil, are made by him so insensible to pain on the rack, that they rather allow themselves to be torn to pieces than confess. Fourteenth chapter: Upon torture and the mode of 
racking. In order to bring the accused to voluntary confession, you may promise her her life; which promise, however, may afterwards be withdrawn. If the witch does not confess the first day, the torture to be continued the second and third days. But here the difference between continuing and repeating is important. The torture may not be continued without fresh evidence, but it may be repeated according to judgment. Fifteenth chapter: Continuance of the discovery of a witch by her marks. Amongst other signs, weeping is one. It is a damning thing if the accused, on being brought up, cannot shed tears. The clergy and judges lay their hands on the head of the accused, and adjure her by the hot tears of the Most Glorified Virgin that in case of her innocence, she shed abundant tears in the name of God the Father.'*

The 6 Bull' and 'Malleus' were the code and textbook of Witcheraft amongst the Catholics, as the Act and 'Demonologie' of James VI. were of the Pro-testants. Perhaps the most important result of the former was to withdraw entirely the authorised prosecution and punishment of the criminals from the civil to the ecclesiastical tribunals. Formerly they

* Ennemoser's History of Magic. Translated by W. Howitt. There are three kinds of men whom witcheraft eannot touch-magistrates; clergymen exercising the pious rites of the Church; and caints, who are under the immediate protection of the angels. 
had a divided jurisdiction. At the same time the fury of popular and judicial fanaticism was greatly inflamed by this new sanction. Immediately, and almost simultaneously, in different parts of Europe, heretical witches were hunted up, tortured, burned, or hanged; and those parts of the Continent most infected with the widening heresy suffered most. The greater number in Germany seems to show that the dissentients from Catholic dogma there were rapidly increasing, some time before Luther thundered out his denunciations. An unusual storm of thunder and lightning in the neighbourhood of Constance was the occasion of burning two old women, Ann Mindelen and one 'Agnes.' porary writer asserts that 1,000 persons were put to death in one year in the district of Como; and Remigius, one of the authorised inquisitores pravitatis haretica, boasts of having burned 900 in the course of fifteen years. Martin del Rio states 500 were executed in Geneva in the short space of three months in 1515; and during the next five years 40 were burned at Ravensburgh. Great numbers suffered in France at the same period. At Calahorra, in Spain, in 1507, a vast auto-da-fé was exhibited, when 39 women, denounced as sorceresses, were committed to the flames-religious carnage attested

* Hutchison's Historical Essay concoming Witcheraft, chap ii. 
by the unsuspected evidence of the judges and executioners themselves.

It is opportune here to examine the common beliefs of demonology and sorcery as they existed in Europe. Christian demonology is a confused mixture of pagan, Oriental, and Christian ideas. The Christian Scriptures have seemed to suggest and sanction a constant personal interference of the 'great adversary,' who is always traversing the earth 'seeking whom he may devour;' and his popular figure is represented as a union of the great dragon, the satyrs, and fauns. Nor does he often appear without one or other of his recognised marks-the cloven foot, the goat's horns, beard, and legs, or the dragon's tail. With young and good-looking witches he is careful to assume the recommendations of a young and handsome man, whilst it is not worth while to disguise so unprepossessing peculiarities in his incarnate manifestations to old women, the enjoyment of whose souls is the great purpose of seduction.

Sir Thomas Browne ('Vulgar Errors'), a man of much learning and still more superstitious fancy, speciously explains the phenomenon of the cloven foot. He suggests that 'the ground of this opinion at first might be his frequent appearing in the shape of a goat, which answers this description. This was the opinion of the ancient Christians concerning the 
apparitions of panites, fauns, and satyrs: and of this form we read of one that appeared to Anthony in the wilderness. The same is also confirmed from exposition of Holy Scripture. For whereas it is said "Thou shalt not offer unto devils," the original word is Seghuirim, i. e. rough and hairy goats; because in that shape the devil most often appeared, as is expounded by the rabbins, as Tremellius hath also explained; and as the word Ascimah, the God of Emath, is by some explained.' Dr. Joseph Mede, a pious and learned divine, author of the esteemed 'Key to the Apocalypse,' pronounces that 'the devil could not appear in human shape while man was in his integrity, because he was a spirit fallen from his first glorious perfection, and therefore must appear in such shape which might argue his imperfection and abasement, which was the shape of a beast; otherwise [he plausibly contends] no reason can be given why he should not rather have appeared to Eve in the shape of a woman than of a serpent. But since the fall of man the case is altered; now we know he can take upon him the shape of a man. He appears in the shape of man's imperfection rather for age or deformity, as like an old man (for so the witches say); and, perhaps, it is not altogether false, which is vulgarly affirmed, that the devil appearing in human shape has always a deformity of some uncouth member or other, as though he could 
not yet take upon him human shape entirely, for that man is not entirely and utterly fallen as he is.' Whatever form he may assume, the cloven foot must always be visible under every disguise; and Othello looks first for that fabulous but certain sign when he scrutinises his treacherous friend.

Reginald Scot's reminiscences of what was instilled into him in the nursery may possibly occur to some even at this day. ' In our childhood,' he complains, ' our mothers' maids have so terrified us with an ugly devil having horns on his head, fire in his mouth, a tail in his breech, eyes like a bison, fangs like a dog, a skin like a niger, a voice roaring like a lion, whereby we start and are afraid when we hear one cry Boh!' Chaucer has expressed the belief of his age on the subject. It seems to have been a proper duty of a parish priest to bring to the notice of his ecclesiastical superior, with other crimes, those of sorcery. The Friar describes his 'Erchedeken' as one-

That boldely didde execucioun

In punyschying of fornicacioun, Of wicchecraft . . .

This ecclesiastic employed in his service a subordinate 'sompnour,' who, in the course of his official duty, one day meets a devil, whose 'dwellynge is in Helle,' who condescends to enlighten the officer on the dark subject of demon-apparitions :-

When us liketh we can take us on

Or ellis make you seme that we ben schape 
Som tyme like a man or like an ape;

Or like an aungel can I ryde or go:

It is no wonder thing though it be so,

A lowsy jogelour can deceyve the;

And, parfay, yet can I nore craft than he.

\section{To the question why they are not satisfied with one} shape for all occasions, the devil answers at length :-

Som tyme we ben Goddis instrumentes

And menes to don his commandementes,

Whan that him liste, upon his creatures

In divers act and in divers figures.

Withouten him we have no might certayne

If that him liste to stonden ther agayne.

And som tyme at our prayer, have we leve

Only the body and not the soule grere;

Witnesse on Job, whom we didde ful wo.

And som tyme have we might on bothe two,

That is to say of body and soule eeke

And som tyme be we suffred for to seeke

Upon a man and don his soule unrest

And not his body, and al is for the best.

Whan he withstandeth our temptacioun

It is a cause of his savacioun.

$\mathrm{Al}$ be it so it was naught our entente

He schuld be sauf, but that we wolde him hente.

And som tyme we ben servaunt unto man

As to the Erchebisschop Saynt Dunstan;

And to the Apostolis servaunt was I.

Som tyme we fegn, and som tyme we ryse

With dede bodies, in ful wonder wyse,

And speke renably, and as fayre and wel

As to the Phitonissa dede Samuel:

And yit wil som men say, it was not he.

I do no fors of your divinitie.*

* Canterbury Tales. T. Wright's Text. Chaucer, the English Boccaccio in rerse, attacks alike with his sarcasms the Church and the female sex. 
Jewish theology, expanded by their leading divines, includes a formidable array of various demons; and the whole of nature in Christian belief was peopled with every kind

' Of those demons that are found

In fire, air, flood, or under ground.'

Various opinions have been held concerning the nature of devils and demons. Some have maintained, with Tertullian, that they are 'the souls of baser men.' It is a disputed question whether they are mortal or immortal; subject to, or free from, pain. ? Psellus, a Christian, and sometime tutor to Michael Pompinatius, Emperor of Greece, a great observer of the nature of devils, holds they are corporeal, and live and die: . . . that they feel pain if they be hurt (which Cardan confirms, and Scaliger justly laughs him to scorn for); and if their bodies be cut, with admirable celerity they come together again. Austin approves as much; so doth Hierome, Origen, Tertullian, Lactantius, and many eminent fathers of the Church; that in their fall their bodies were changed into a more aerial and gross substance.' The Platonists and some rabbis, Porphyrius, Plutarch, Zosimus, \&c., hold this opinion, which is scornfully denied by some others, who assert that they only deceive the eyes of men, effecting no real change. Cardan believes 'they feed on men's souls, and so [a worthy 
origin] belike that we have so many battles fought in all ages, countries, is to make them a feast and their sole delight: but if displeased they fret and chafe (for they feed belike on the souls of beasts, as we do on their bodies) and send many plagues amongst us.'

Their exact numbers and orders are differently estimated by different authorities. It is certain that they fill the air, the earth, the water, as well as the subterranean globe. The air, according to Paracelsus, is not so full of flies in summer as it is at all times of invisible devils. Some writers, professing to follow Socrates and Plato, determine nine sorts. Whatever

$\therefore$ or wherever the supralunary may be, our world is more interested in the sublunary tribes. These are variously divided and subdivided. One authority computes six distinct kinds-Fiery, Aerial, Terrestrial, Watery, Subterranean and Central: these last inhabiting the central regions of the interior of the earth. The Fiery are those that work 'by blazing stars, fire-drakes; they counterfeit suns and moons, stars oftentimes. The Aerial live, for the most part, in the air, cause many tempests, thunder and lightning, tear oaks, fire steeples, houses; strike men and beasts; make it rain stones, as in Livy's time, wool, frogs, \&c.; counterfeit armies in the air, strange noises . . . all which Guil. Postellus useth as an argument (as, indeed, it is) to persuade them that 
will not believe there be spirits or devils. They cause whirlwinds on a sudden and tempestuous storms, which, though our meteorologists generally refer to natural causes, yet I am of Bodine's mind, they are more often caused by those aerial devils in their several quarters; for they ride on the storms as when a desperate man makes away with himself, which, by hanging or drowning, they frequently do, as Kormannus observes, tripudium agentes, dancing and rejoicing at the death of a sinner. These can corrupt the air, and cause sickness, plagues, storms, shipwrecks, fires, inundations. . . . . Nothing so familiar (if we may believe those relations of Saxo Grammaticus, Olaus Magnus, \&c.) as for witches and sorcerers in Lapland, Lithuania, and all over Scandia to sell winds to mariners and cause tempests, which Marcus Paulus, the Venetian, relates likewise of the Tartars.*

'These are they which Cardan thinks desire so much carnal copulation with witches (Incubi and Succubi), transform bodies, and are so very cold if they be touched, and that serve magicians. . . . Water devils are those naiads or water nymphs which have been heretofore conversant about waters and rivers. The water (as Paracelsus thinks) is their chaos,

* It is still the custom of the Tartar or Thibetian Lamas, or at least of some of them, to scatter charms to the winds for the benefit of travellers. M. Huc's Travels in Tartary, Thibet, \&c. 
wherein they live . . appearing most part (saith Trithemius) in women's shapes. Paracelsus hath several stories of them that have lived and been married to mortal men, and so continued for certain years with them, and after, upon some dislike, have forsaken them. Such an one was Egeria, with whom Numa was so familiar, Diana, Ceres, \&c. . . . Terrestrial devils are Lares, Genii, Fauns, Satyrs, Wood-nymphs, Foliots, Fairies, Robin Goodfellows, Trulli; which, as they are most conversant with men, so they do them most harm. Some think it was they alone that kept the heathen people in awe of old. . . . Subterranean devils are as common as the rest, and do as much harm. Olaus Magnus makes 'six kinds of them, some bigger, some less, commonly seen about mines of metals, and are some of them noxious; some again do no harm (they are guardians of treasure in the earth, and cause earthquakes). The last (sort) are conversant about the centre of the earth, to torture the souls of damned men to the day of judgment; their egress and ingress some suppose to be about Atna, Lipari, Hecla, Vesuvius, Terra del Fuego, because many shrieks and fearful cries are continually heard thereabouts, and familiar apparitions of dead men, ghosts, and goblins.'

As for the particular offices and operations of those various tribes, 'Plato, in Critias, and after him his 
followers, gave out that they were men's governors and keepers, our lords and masters, as we are of our cattle. They govern provinces and kingdoms by oracles, auguries, dreams, rewards and punishments, prophecies, inspirations, sacrifices and religious superstitions, varied in as many forms as there be diversity of spirits; they send wars, plagues, peace, sickness, health, dearth, plenty, as appears by those histories of Thucydides, Livius, Dionysius Halicarnassensis, with many others, that are full of their wonderful stratagems.' They formerly devoted themselves, each one, to the service of particular individuals as familiar demons, ' private spirits.' Numa, Socrates, and many others were indebted to their Genius. The power of the devil is not limited to the body. ' Many think he can work upon the body, but not upon the mind. But experience pronounceth otherwise, that he can work both upon body and mind. Tertullian is of this opinion.'

The causes and inducements of 'possession' are many. One writer affirms that 'the devil being a slender, incomprehensible spirit can easily insinuate and wind himself into human bodies, and cunningly couched in our bowels, vitiate our healths, terrify our souls with fearful dreams, and shake our minds with furies. They go in and out of our bodies as bees do in a hive, and so provoke and tempt us as they perceive our temperature inclined of itself and most apt to be deluded. . . Agrippa and Lavater are . 
persuaded that this humour [the melancholy] invites the devil into it, wheresoever it is in extremity, and, of all other, melancholy persons are most subject to diabolical temptations and illusions, and most apt to entertain them, and the devil best able to work upon them. 'But whether,' declares Burton, 'by obsession, or possession, or otherwise, I will not determine ; 'tis a difficult question."*

The mediævalists believed themselves surrounded everywhere by spiritual beings; but unlike the ancients, they were convinced not so much that they were the peculiar care of heaven as that they were the miserable victims of hellish malice, ever seeking their temporal as well as eternal destruction; a fact apparent in the whole mediæval literature and art. $\dagger$

* The Anatomy of Melancholy, by Democritus junior; edited by Democritus minor. Part i. sect. 2. An equally copious and curious display of learning. Few authors, probably, have been more plagiarised.

+ Sismondi (Literature of the South of Europe) has observed of the greatest epic of the Middle Age, that 'Dante, in common with many fathers of the Church, under the supposition that paganism, in the persons of the infernal gods, represented the fallen angels, has made no scruple to adopt its fables.' Tasso, at a later period, introduces the deities of heathendom. In the Gerusalemme Liberata they sit in council to frustrate the plans and destroy the forces of the Christian leaders before Jerusalem (iv). Ismeno, a powerful magician in the ranks of the Turks, brings up a host of diabolic allies to guard the wood which supplied the infidels with materials for carrying on the siege of the eity (xiii.). And the masterpieces of art of Guido or Raffaelle, which excite at once admiration and despair in their modern disciples, consecrated and immortalised the vulgar superstition. 
Glanvil's conjectures on the cause of the comparative rarity of demoniac and other spiritual apparitions in general may interest the credulous or curious reader. 'Tis very probable,' reasons the Doctor, 'that the state wherein they are will not easily permit palpable intercourses between the bad genii and mankind : since 'tis like enough their own laws and government do not allow their frequent excursions into the world. Or it may with great probability be supposed that 'tis a very bard and painful thing for them to force their thin and tenuious bodies into a visible consistence, and such shapes as are necessary for their designs in their correspondence with witches. For in this action their bodies must needs be exceedingly compressed, which cannot well be without a painful sense. And this is, perhaps, a reason why there are so few apparitions, and why appearing spirits are commonly in such a hurry to be gone, viz. that they may be delivered of the unnatural pressure of their tender vehicles, ${ }^{*}$ which I confess holds more in the apparition of good than evil spirits . . . the reason of which probably is the greater subtlety and tenuity of the former, which will require far greater degrees of compression and consequently of pain to make them visible; whereas the latter are feculent and

* So specious a theory must have occurred to, and its propriety will easily be recognised by, the spirit and ghost adrocates of the present day. 
gross, and so nearer allied to palpable existences, and more easily reducible to appearance and visibility.'*

'Palpable intercourses between the bad genii and mankind' are more frequent than Dr. Glanvil was disposed to believe; and he must have been conversant with the acts of Incubus and Succubus. In the first age (orbe novo cœloque recenti) under the Saturnian regime, 'while yet there was no fear of Jove, $†$ innocence prevailed undisturbed; but soon as the silver age was inaugurated by the usurpation of Jove, liaisons between gods and mortals became frequent. Love affairs between good or bad 'genii' and mankind are of common occurrence in the mythology of most peoples. In the romance-tales of the middle age lovers find themselves unexpectedly connected with some mysterious being of inhuman kind. The writers in defence of witcheraft quote Genesis vi. in proof of the reality of such intercourses; and Justin Martyr and Tertullian, the great apologists of Christianity, and others of the Fathers, interpret Filios Dei to be angels or evil spirits who, enamoured with the beauty of the women, begot the primeval giants.

* Sadducismus Triumphatus. Considerations about Witcheraft. Sect. xi.

†'Jove nondum Barbato.'

$\ddagger$ Milton indignantly exclaims, alluding to this common fancy of the leaders of the Primitive Church, "Who would think him fit to 
Some tremendous results of diabolic connections appear in the metrical romances of the twelfth or thirteenth century, as well as in those early AngloNorman chroniclers or fabulists, who have been at the pains to inform us of the pre-historic events of their country. The author of the romance-poem of the well-known Merlin-so famous in British prophecy-in introducing his hero, enters upon a long dissertation on the origin of the infernal arts. $\mathrm{He}$ informs us on the authority of 'David the prophet, and of Moses,' that the greater part of the angels who rebelled under the leadership of Lucifer, lost 'their former power and beauty, and became 'fiendes black :' that instead of being precipitated into 'hellepit,' many remained in mid-air, where they still retain the faculty of seducing mortals by assuming whatever shape they please. These had been much

write an apology for Christian faith to the Roman Senate that could tell them "how of the angels" - of which he must needs mean those in Genesis called the Sons of God-" mixing with women were begotten the devils," as good Justin Martyr in his Apology told them.' (Reformation in England, book i.). And 'Clemens Alexandrinus, Sulpicius Severus, Eusebius, \&c., make a twofold fall of angels-one from the beginning of the world; another a little before the deluge, as Moses teacheth us, openly professing that these genii can beget and have carnal copulation with woman' (Anatomy of Melancholy, part i.). Robert Burton gires in his adhesion to the sentiments of Lactantius (xiv. 15). It seems that the later Jewish devils owe their origin (according to the Talmudists, as represented by Pererius in the Anatomy) to a former wife of Adam, called Lilis, the predecessor of Ere. 
concerned at the miraculous birth of Christ; but it was hoped to counteract the salutary effects of that event, by producing from some virgin a semi-demon, whose office it should be to disseminate sorcerers and wicked men. For this purpose the devil * prepares to seduce three young sisters; and proceeds at once in proper disguise to an old woman, with whose avarice and cunning he was well acquainted. Her he engaged by liberal promises to be mediatrix in the seduction of the elder sister, whom he was prevented from attempting in person by the precautions of a holy hermit. Like ' the first that fell of womankind,' the young lady at length consented; was betrayed by the fictitious youth, and condemned by the law to be burnt alive.

The same fate, excepting the fearful penalty, awaited the second. And now, too late, the holy hermit became aware of his disastrous negligence. $\mathrm{He}$ strictly enjoined on the third and remaining sister a constant watch. Her security, however, was the cause of her betrayal. On one occasion, in a moment of remissness, she forgot her prayers and the sign of the cross, before retiring for the night. No longer excluded, the fiend, assuming human shape, effected his purpose. In due time a son was born, * Probably,

'Belial, the dissolutest spirit that fell, The sensualist; and after Asmodai The fleshliest Incubus.'-Par. Reg. 
whose parentage was sufficiently evinced by an entire covering of black hair, although his limbs were wellformed, and his features fine. Fortunately, the careless guardian had exactly calculated the moment of the demon's birth; and no sooner was he informed of the event, than the new-born infant was borne off to the regenerating water, when he was christened by the name of Merlin; the fond hopes of the demons being for this time, at least, irretrievably disappointed. How Merlin, by superhuman prowess and knowledge, defeated the Saracens (Saxons) in many bloody battles; his magical achievements and favour at the court of King Vortigern and his successors, are fully exhibited by the author of the history.* Geoffrey of Monmouth recounts them as matters of fact; and they are repeated by Vergil in the History of Britain, composed under the auspices of Henry VIII.

By the ancients, whole peoples were sometimes said to be derived from these unholy connections. Jornandes, the historian of the Groths, is glad to be able to relate their hated rivals, the Huns (of whom the Kalmuck Tartars are commonly said to be the modern representatives), to have owed their origin to an intercourse of the Scythian witches with infernal spirits. The extraordinary form and features of those dreaded emigrants from the steppes of Tartary, had

* See Early English Metrical Romances, ed. by Sir H. Ellis. 
suggested to the fear and hatred of their European subjects, a fable which Gibbon supposes might have been derived from a more pleasing one of the Greeks.*

The acts of Incubus assume an important part in witch-trials and confessions. Incubus is the visitor of females, Succubus of males. Chaucer satirises the gallantries of the vicarious Incubus by the mouth of the wife of Bath (that practical admirer of Solomon and the Samaritan woman), $\dagger$ who prefaces her tale with the assurance :-

* A sufficiently large collection from' ancient and modern writers of the facts of inhuman connections may be seen in the Anatomy of Melancholy, part iii. sect. 2. Having repeated the assertions of previous authors proving the fact of intercourses of human with inferior species of animals, Burton fortifies his own opinion of their reality by numerous authorities. If those stories be true, he reasons, that are written of Ineubus and Suceubus, of nymphs, lascivious fauns, satyrs, and those heathen gods which were devils, those lascivious Telchines of whom the Platonists tell so many fables; or those familiar meetings in our day [1624] and company of witches and devils, there is some probability for it. I know that Biarmannus, Wierus, and some others stoutly deny it . . . but Austin (lib. xv. de Civit. Dei) doth acknowledge it. And he refers to Plutarch, Vita Nume; Wierus, de Prestigiis Damon., Giraldus Cambrensis, Malleus Malef., Jacobus Reussus, Godelman, Erastus, John Nider, Delrio, Lipsius, Bodin, Pererius, King James, \&c. The learned and curious work of the melancholy Student of Christ Church and Oxford Rector has been deservedly commended by many eminent critics. That 'exact mathematician and curious calculator of nativities' calculated exactly, according to Anthony Wood (Athence Oxon.), the period of his own death -1639 .

† The wife of Bath, who had buried only her fifth husband, must appear modest by comparison. Not to mention Seneca's or Martial's 
That maketh that ther ben no fayeries, For ther as wont was to walken an elf Ther walketh noon but the Lymitour himself.

Women may now go safely up and downe;

In every busch and under every tre

Ther is noon other Incubus but he.

Reginald Scot has devoted several chapters of his work to a relation of the exploits of Incubus.* But he honestly warns his readers 'whose chaste ears cannot well endure to hear of such lecheries (gathered out of the books of divinity of great authority) to turn over a few leaves wherein I have, like a groom, thrust their stuff, even that which I myself loath, as into a stinking corner: howbeit none otherwise, I hope, but that the other parts of my writing shall remain sweet.' He repeats a story from the 'Vita Hieronymi,' which seems to insinuate some suspicion of the character of a certain Bishop Sylvanus. It relates that one night Incubus invaded a certain lady's bedroom. Indignant at so unusual, or at least disguised, an apparition, the lady cried out loudly until the guests of the house came and found it under the bed in the likeness of the bishop; 'which holy man,' adds Scot, ' was much defamed thereby.'

assertions or insinuations, St. Jerome was acquainted with the case of a woman who had buried her twenty-second husband, whose colljugal capacity, however, was exceeded by the Dutch wife who, on the testimony of honest John Evelyn, had buried her twenty-fifth husband!

* See the fourth book of the Discoverie. 
Another tradition or legend seems to reflect upon the chastity of the greatest saint of the Middle Ages.* The superbuman oppression of Incubus is still rememberred in the proverbial language of the present day. The horrors of the infernal compacts and leagues, as exhibited in the fates of wizards or magicians at the last hour, formed one of the most popular scenes on the theatrical stage. Christopher Marlow, in 'The Life and Death of Dr. Faustus,' and Robert Greene, in 'Friar Bacon and Friar Bungay,' in the Elizabethan age, dramatised the common conception of the Compact.

* 'It is written in the legend of St. Bernard,' we are told, 'that a pretty wench that had the use of Incubus his body by the space of six or seven years in Aquitania (being belike weary of him for that he waxed old), would needs go to St. Bernard another while. But Incubus told her if she would so forsake him, he would be revenged upon her. But befal what would, she went to St. Bernard, who took her his staff and bad her lay it in the bed beside her. And, indeed, the devil, fearing the staff or that St. Bernard lay there himself, durst not approach into her chamber that night. What he did afterwards I am uncertain.' This story will not appear so evidential to the reader as Scot seems to infer it to be. If any credit is to be given to the strong insinuations of Protestant divines of the sixteenth century, the 'holy bishop Sylvanus' is not the only example among the earlier saints of the frailty of human nature. 


\section{CHAPTER II.}

Three Sorts of Witches-Various Modes of Witcheraft Manner of Witch-Travelling-The Sabbaths-Anathemas of the Popes against the Crime-Bull of Adrian VI.-Cotemporary Testimony to the Severity of the Persecutions-Necessary Triumph of the Orthodox Party-Germany most subject to the Superstition-Acts of Parliament of Henry against Witchcraft-Elizabeth Barton-The Act of 1562-Executions under Queen Elizabeth's Government-Case of Witcheraft narrated by Reginald Scot.

THE ceremonies of the compact by which a woman became a witch have been already referred to. It was almost an essential condition in the vulgar creed that she should be, as Gaule ('Select Cases of Conscience touching Witches,' \&c., 1646) represents, an old woman with a wrinkled face, a furred brow, a hairy lip, a gobber tooth, a squint eye, a squeaking voice, a scolding tongue, having a ragged coat on her back, a skull-cap on her head, a spindle in her hand, a dog or cat by her side. There are three sorts of the devil's agents on earth-the black, the gray, and the white witches. The first are omnipotent for evil, but powerless for good. The white have the power to help, but not to hurt.* As for the third

* A writer at the beginning of the seventeenth century (Cotta, Tryall of Witchcraft) says, "This kind is not obscure at this day, swarming in 
species (a mixture of white and black), they are equally effective for good or evil.

Equally various and contradictory are the motives and acts assigned to witches. Nothing is too great or too mean for their practice: they engage with equal pleasure in the overthrow of a kingdom or a religion, and in inflicting the most ordinary evils and mischiefs in life. Their mode of bewitching is various: by fascination or casting an evil eye ('Nescio,' says the Virgilian shepherd, 'quis teneros oculus mihi fascinat agnos'); by making representations of the person to be acted upon in wax or clay, roasting them before a fire; by mixing

this kingdom, whereof no man can be ignorant who lusteth to observe the uncontrouled liberty and licence of open and ordinary resort in all places unto wise men and wise women, so vulgarly termed for their reputed knowledge concerning such diseased persons as are supposed to be bewitched.' And (Short Discoverie of Unobserved Dangers, 1612) ' the mention of witchecraft doth now occasion the remembrance in the next place of a sort of practitioners whom our custom and country doth call wise men and wise women, reputed a kind of good and honest harmless witches or wizards, who, by good words, by hallowed herbs and salves, and other superstitious ceremonies, promise to allay and calm devils, practices of other witches, and the forces of many diseases.' Another writer of the same date considers 'it were a thousand times better for the land if all witches, but specially the blessing witch, might suffer death. Men do commonly hate and spit at the damnifying sorcerer as unworthy to live among them, whereas they fly unto the other in necessity; they depend upon him as their God, and by this means thousands are carried away, to their final confusion. Death, therefore, is the just and deserred portion of the good witch.'-Observations on the Popular Antiquities of Great Britain, by Brand, ed. by Sir H. Ellis. 
magical ointments or other compositions and ingredients revealed to us in the witch-songs of Shakspeare, Jonson, Middleton, Shadwell, and others; sometimes merely by muttering an imprecation.

They ride in sieves on the sea, on brooms, spits magically prepared; and by these modes of conveyance are borne, without trouble or loss of time, to their destination. By these means they attend the periodical sabbaths, the great meetings of the witchtribe, where they assemble at stated times to do homage, to recount their services, and to receive the commands of their lord. They are held on the night between Friday and Saturday; and every year a grand sahbath is ordered for celebration on the Blocksberg mountains, for the night before the first day of May. In those famous mountains the obedient vassals congregate from all parts of Christendom-from Italy, Spain, Germany, France, England, and Scotland. A place where four roads meet, a rugged mountain range, or perhaps the neighbourhood of a secluded lake or some dark forest, is usually the spot selected for the meeting.*

* "When orders had once been issued for the meeting of the sabbath, all the wizards and witches who failed to attend it were lashed by demons with a rod made of serpents or scorpions. In France and England the witebes were supposed to ride uniformly upon broomsticks; but in Italy and Spain, the devil himself, in the shape of a goat, used to transport them on his back, which lengthened or shortened according to the number of witches he was desirous of accommodating. No witch, when proceeding to the sabbath, conld get out 


\section{A mock sermon often concludes the night's pro-} ceedings, the ordinary salutation of the osculum in

by a door or window were she to try ever so much. Their general mode of ingress was by the key-hole, and of egress by the chimney, up which they flew, broom and all, with the greatest ease. To prevent the absence of the witches being noticed by their neighbours, some inferior demon was commanded to assume their shapes, and lie in their beds, feigning illness, until the sabbath was over. When all the wizards and witches had arrived at the place of rendezvous, the infernal ceremonies began. Satan having assumed his favourite shape of a large he-goat, with a face in front and another in his haunches, took his seat upon a throne; and all present in succession paid their respects to him and kissed him in his face behind. This done, he appointed a master of the ceremonies, in company with whom he made a personal examination of all the witches, to see whether they had the secret mark about them by which they were stamped as the devil's own. This mark was always insensible'to pain. Those who had not yet been marked receired the mark from the master of the ceremonies, the devil at the same time bestowing nick-names upon them. This done, they all began to sing and dance in the most furious manner until some one arrived who was anxious to be admitted into their society. They were then silent for a while until the new comer had denied his salvation, kissed the devil, spat upon the Bible, and sworn obedience to him in all things. They then began dancing again with all their might and singing. . . . In the course of an hour or two they generally became wearied of this violent exercise, and then they all sat down and recounted their evil deeds since last meeting. Those who had not been malicious and mischierous enough towards their fellow-creatures received personal chastisement from Satan himself, who flogged them with thorns or scorpions until they were covered with blood and unable to sit or stand. When this ceremony was concluded, they were all amused by a dance of toads. Thousands of these creatures sprang out of the earth, and standing on their hind-legs, danced while the devil played the bagpipes or the trumpet. These toads were all endowed with the faculty of speech, and entreated the witches there to reward them with the flesh of unbaptized infants for their exertions to gire them pleasure. The witches promised compliance. The devil bade them 
tergo being first given. But these circumstances are innocent compared with the obscene practices when the lights are put out; indiscriminate debauchery being then the order of the night. A new rite of baptism initiated the neophyte into his new service: the candidate being signed with the sign of the devil on that part of the body least observable, and submitting at the same time to the first act of criminal compliance, to be often repeated. On these occasions the demon presents himself in the form of either sex, according to that of his slaves. It was elicited from a witch examined at a trial that, from the period of her servitude, the devil had had inter-

remember to keep their word; and then stamping his foot, caused all the toads to sink into the earth in an instant. The place being thus cleared, preparations were made for the banquet, where all manner of disgusting things were served up and greedily devoured by the demons and witches, although the latter were sometimes regaled with choice meats and expensive wines, from golden plates and crystal goblets; but they were never thus favoured unless they had done an extraordinary number of evil deeds since the last period of meeting. After the feast, they began dancing again; but such as had no relish for any more exercise in that way, amused themselves by mocking the holy sacrament of baptism. For this purpose the toads were again called up, and sprinkled with filthy water, the devil making the sign of the cross, and all the witches calling out-[some gibberish]. When the devil wished to be particularly amused, he made the witches strip off their clothes and dance before him, each with a cat tied round her neck, and another dangling from her body in form of a tail. When the cock erew they all disappeared, and the sabbath was ended. This is a summary of the belief that prevailed for many centuries nearly all over Europe, and which is far from eradicated even at this day.'-Memoirs of Extraordinary Popular Delusions, by C. Mackay. 
- course with her ut vivi cum fominis solent, excepting only in one remarkable particular.

During the pontificate of Julius II.- the first decade of the sixteenth century - a set of sorceresses was diseovered in large numbers: a dispute between the civil and eeelesiastical authorities averted their otherwise certain destruction. The successors of Innocent VHI.-repeated his anathemas. Alexander VI., Leo X., and Adrian VI. appointed special commis-sioners for hunting up sorcerers and heretics. In 1523, Adrian issued a bull against Horesis Strigiatûs with power to excommunicate all who opposed those engaged in the inquisition. He characterises the obnoxious class as a sect deviating from the Catholic faith, denying their baptism, showing contempt for the sacraments, in particular for that of the Eucharist, treading crosses under foot, and taking the devil as their lord.* How many suffered for the crime during the thirty or forty years following upon the bull of 1484, it is difficult exactly to ascertain: that some thousands perished is certain, on the testimony of the judges themselves. The often-quoted words of Florimond, author of a work ' On Antichrist,' as given by Del Rio the Jesuit ('De Magiâ'), are not hyperbolical. 'All those,' says he, 'who have afforded us some signs of the approach of antichrist agree that the increase

* Francis Hutchison's Historical Essay concerning Witchcraft, chap. xiv.; the author quotes Barthol. de Spina, de Strigibus. 
of sorcery and witchcraft is to distinguish the melancholy period of his advent; and was ever age so afflicted with them as ours? The seats destined for criminals before our judicatories are blackened with persons accused of this guilt. There are not judges enough to try enough. Our dungeons are gorged with them. No day passes that we do not render our tribunals bloody by the dooms we pronounce, or in which we do not return to our homes discountenanced and terrified at the horrible contents of the confessions which it has been our duty to hear. And the devil is accounted so good a master that we cannot commit so great a number of his slaves to the flames but what there shall arise from their ashes a number sufficient to supply their place.'

It is within neither the design nor the limits of these pages to repeat all the witch-cases, which might fill several volumes; it is sufficient for the purpose to sketch a few of the most notorious and prominent, and to notice the most remarkable characteristics of the creed.

Maximilian I., Emperor of Germany, protected the inquisitorial executioners from the indignant vengeance of the inhabitants of the districts of Southern Germany, which would have been soon almost depopulated by an unsparing massacre and a ferocious zeal : while Sigismund, Prince of the Tyrol, is said to have been inclined to soften the severity of a persecution he was totally unable, if he had been 
disposed, to prevent. Ulric Molitor, under the auspices of this prince, however, published a treatise in Switzerland ('De Pythonicis Mulieribus') in the form of a dialogue, in which Sigismund, Molitor, and a citizen of Constance are the interlocutors. They argue as to the practice of witchcraft; and the argument is to establish that, although the practicers of the crime are worthy of death, much of the vulgar opinion on the subject is false. Even in the middle of the fifteenth century, and in Spain, could be found an assertor, in some degree, of common sense, whose sentiments might scandalise some Protestant divines. Cl le bra Alphonse de Spina was a native of Castile, of the order of St. Francis : his book was written against heretics and unbelievers, but there is a chapter in which some acts attributed to sorcerers, as transportation through the air, transformations, \&c., are rejected as unreal.

From that time two parties were in existence, one of which advocated the entire reality of all the acts commonly imputed to witches; while the other maintained that many of their supposed crimes were mere delusions suggested by the Great Enemy. The former, as the orthodox party, were, from the nature of the case, most successful in the argument-a seeming paradox explained by the nature and course of the controversy. Only the received method of demoniacal possession was questioned by the adverse side, accepting without doubt the possibility-and, 
indeed, the actual existence-of the phenomenon. Thus the liberals, or pseudo-liberals, in that important controversy were placed in an illogical position. For (as their opponents might triumphantly argue) if the devil's power and possession could be manifested in one way, why not by any other method. Nor was it for them to determine the appointed methods of his schemes, as permitted by Providence, for the injury and ruin of mankind. The diabolic economy, as evidently set forth in the work of man's destruction, might require certain modes of acting quite above our reason and understanding. To the sceptics (or to the atheists, as they were termed) the orthodox could allege, "Will you not believe in witches? The Scriptures aver their existence: to the jurisconsults will you dispute the existence of a crime against which our statute-book and the code of almost all civilised countries have attested by laws upon which hundreds and thousands have been convicted; many, or even most, of whom have, by their judicial confessions, acknowledged their guilt and the justice of their punishment? It is a strange scepticism, they might add, that rejects the evidence of Scripture, of human legislature, and of the accused persons themselves.' * Reason was hopelessly oppressed by faith. In the presence of universal superstition, in the absence of the modern philosophy, escape seemed all but impossible.

* Sir W. Scott's Letters on Demonology and Witchcraft, chap. vi. 
If preeminence in this particular prejudice can be assigned to any single region or people, perhaps Germany more than any other land was subject to the demonological fever. A fact to be explained as well by its being the great theatre for more than a hundred years of the grand religious struggle between the opposing Catholics and Protestants, as by its natural fitness. The gloomy mountain ranges-the Hartz mountains are especially famous in the national legend-and forests with which it abounds rendered the imaginative minds of its peoples peculiarly susceptible to impressions of supernaturalism.* France takes the next place in the fury of the persecution. Danæus ('Dialogue') speaks of an innumerable number of witches. England, Scotland, Spain, Italy perhaps come next in order.

Spain, the dominion of the Arabs for seven centuries, was naturally the land of magic. During the government of Ferdinand I., or of Isabella, the inquisition was firmly established. That numbers were sent from the dungeons and torture-chambers to the stake, with the added stigma of dealing in the 'black art,' is certain ; but in that priest-dominated, servilely orthodox southern land, the Church was not perhaps so much interested in confounding the crimes of

* How greatly the imagination of the Germans was attracted by the supernatural and the marvellous is plainly seen both in the old national poems and in the great work of the national mythologist, Jacob Grimm (Deutsche Mythologie). 
heresy and sorcery. The first was simply sufficient for provoking horror and hatred of the condemned. The South of France is famous for being the very nest of sorcery: the witch-sabbaths were frequently held there. It was the country of the Albigenses, which had been devastated by De Montfort, the executioner of Catholic vengeance, in the twelfth century, and was, with something of the same sort of savageness, ravaged by De Lanere in the seventeenth century. Scotland, before the religious revolution, exhibits a few remarkable cases of witch-persecution, as that of the Earl of Mar, brother of James III. - He had been suspected of calling in the aid of sorcery to ascertain the term of the king's life: the earl was bled to death without trial, and his death was followed by the burning of twelve witches, and four wizards, at Edinburgh. Lady Glammis, sister of the Earl of Angus, of the family of Douglas, accused of conspiring the king's death in a similar way, was put to death in 1537. As in England, in the cases of the Duchess of Gloucester and others, the crime appears to be rather an adjunct than the principal charge itself; more political than popular. Protestant Scotland it is that has earned the reputation of being one of the most superstitious countries in Europe.

In 1541 two Acts of Parliament were passed in England-the first interference of Parliament in this 
kingdom - against false propbecies, conjurations, witcheraft, sorcery, pulling down crosses; crimes made felony without benefit of clergy. Both the last article in the list and the period (a few years after the separation from the Catholic world) appear to indicate the causes in operation. Lord Hungerford had recently been beheaded by the suspicious tyranny of Henry VIII., for consulting his death by conjuration. The preamble to the statute has these words: 'The persons that had done these things, had dug up and pulled down an infinite number of crosses.' $*$ The new head of the English Church, if he found his interest in assuming himself the spiritual supremacy, was, like a true despot, averse to any further revolution than was necessary to his purposes. Some superstitious regrets too for the old establishment which, by a fortunate caprice, he abandoned and afterwards plundered, may have urged the tyrant, who persecuted the Catholics for questioning his supremacy, to burn the enemies of transubstantiation. Shortly before this enactment, eight persons had been hanged at Tyburn, not so much for sorcery as for a disagreeable prophecy. Elizabeth Barton, the principal, had been instigated to pronounce as revelation, that if the

* Hutchison's Historical Essay concerning Witchcraft. The author, chaplain in ordinary to George I., published his book in 1718 . It is worth while to note the colder scepticism of the Hanorerian chaplain as compared with the undoubting faith of his predecessor, Dr. Glanvil. 
king went on in the divorce and married another wife, he should not be king a month longer, and in the estimation of Almighty God not one hour longer, but should die a villain's death. The Maid of Kent, with her accomplices-Richard Martin, parson of the parish of Aldington; Dr. Bocking, canon of Christ Church, Canterbury; Deering ; Henry Gold, a parson in London; Hugh Rich, a friar, and others-was brought before the Star Chamber, and adjudged to stand in St. Paul's during sermon-time; the majority being afterwards executed. In Cranmer's 'Articles of Visitation,' 1549, an injunction is addressed to his clergy, that 'you shall inquire whether you know of any that use charms, sorcery, enchantments, witchcrafts, soothsaying, or any like craft, invented by the devil.'

During the brief reigns of Edward VI. and Mary I. in England, no conspicuous trials occur. As for the latter monarch, the queen and her bishops were too absorbed in the pressing business of burning for the real offence of heresy to be much concerned in discovering the concomitant crimes of devil-worship.*

* Agreeably to that common prejudice which selects certain historical personages for popular and peculiar esteem or execration, and attributes to them, as if they were eccentricities rather than examples of the age, every exceptional virtue or vice, the 'Bloody Queen' has been stigmatised, and is still regarded, as an extraordinary monster, capable of every inhuman crime-a prejudice more popular than philosophieal, since experience has taught that despots, unchecked by fear, by reason, or conscience, are but examples, in an eminent de- 
An impartial judgment may decide that superstition, whether engaged in vindicating the dogmas of Catholicism or those of witchcraft, is alike contemptible and pernicious.

In the year of Elizabeth's accession, 1558, Strype ('Annals of the Reformation,' i. 8, and ii. 545) tells that Bishop Jewell, preaching before the queen, animadverted upon the dangerous and direful results of witchcraft. 'It may please your Grace,' proclaims publicly the courtly Anglican prelate, 'to understand that witches and sorcerers, within these last few years, are marvellously increased within your Grace's realm. Your Grace's subjects pine away even to the death, their colour fadeth, their flesh rotteth, their speech is benumbed, their senses are bereft. I pray God they never practise further than upon the subject.' For himself, the bishop declares, 'these eyes have seen most evident and manifest marks of their wickedness.' The annalist adds that this, no doubt, was the occasion of bringing in a bill the next Parliament, for making enchantments and witchcraft felony; and, under year 1578, we are informed that, whether it were gree, of the character, and personifications of the worst rices (if not of the best virtues) of their time. Considered in this view, Mary I. will but appear the example and personification of the religious intolerance of Catholicism and of the age, just as Cromwell was of the patriotic and Puritanic sentiment of the first half, or Charles II. of the unblushing licentiousness of the last half, of the serenteenth century. 
the effect of magic, or proceeded from some natural cause, the queen was in some part of this year under excessive anguish by pains of her teeth, insomuch that she took no rest for divers nights, and endured very great torment night and day. The statute of 1562 includes 'fond and fantastic prophecies' (a very common sort of political offences in that age) in the category of forbidden arts. With unaccustomed lenity it punished a first conviction with the pillory only.

Witch-persecutions (which needed not any legal enactment) sprung up in different parts of the country; but they were not carried out with either the frequency or the ferocity of the next age, or as in Scotland, under the superintendence of James VI. A number of pamphlets unnecessarily enforced the obligatory duty of unwearied zeal in the work of discovery and extermination.* Among the executions under Elizabeth's Government are specially noticed that of a woman hanged at Barking in 1575;

* One of these productions, printed in London, bore the sensational title, 'A very Wonderful and Strange Miracle of God, shewed upon a Dutchman, of the age of 23 years, who was possessed of ten devils, and was, by God's Mighty Providence, dispossessed of them again the 27 January last past, 1572.' Another, dedicated to Lord Darcy, by W. W., 1582, sets forth that all those tortures in common use 'are far too light, and their rigour too mild; and in this respect he (the pamphleteer) impudently exclaimeth against our magistrates who suffer them to be but hanged, when murtherers and such malefactors be so used, which descrve not the hundredth part of their punishment.'. 
of four at Abingdon; three at Chelmsford; two at Cambridge, 1579; of a number condemned at St. Osythes; of several in Derbyshire and Staffordshire. One of the best known is the case at Warboys, in Huntingdonshire, 1593.

The author of the 'Discoverie' relates a fact that came under his personal observation: it is a fair example of the trivial origin and of the facility of this sort of charges. 'At the assizes holden at Rochester, anno 1581, one Margaret Simons, wife of John Simons, of Brenchly in Kent, was arraigned for witchcraft, at the instigation and complaint of divers fond and malicious persons, and especially by the means of one John Farral, vicar of that parish, with whom I talked about the matter, and found him both fondly assotted in the cause and enviously bent towards her: and, which is worse, as unable to make a good account of his faith as she whom he accused. That which he laid to the poor woman's charge was this. His son, being an ungracious boy, and 'prentice to one Robert Scotchford, clothier, dwelling in that parish of Brenchly, passed on a day by her house; at whom, by chance, her little dog barked, which thing the boy taking in evil part, drew his knife and pursued him therewith even to her door, whom she rebuked with such words as the boy disdained, and yet nevertheless would not be persuaded to depart in a long time. At the last he 
returned to his master's house, and within five or six days fell sick. Then was called to mind the fray betwixt the dog and the boy: insomuch as the vicar (who thought himself so privileged as he little mistrusted that God would visit his children with sickness) did so calculate as he found, partly through his own judgment and partly (as he himself told me) by the relation of other witches, that his said son was by her bewitched. Yea, he told me that his son being, as it were, past all cure, received perfect health at the hands of another witch.' Not satisfied with this accusation, the vicar ' proceeded yet further against her, affirming that always in his parish church, when he desired to read most plainly his voice so failed him that he could scant be heard at all : which he could impute, he said, to nothing else but to her enchantment. When I advertised the poor woman thereof, as being desirous to hear what she could say for herself, she told me that in very deed his voice did fail him, specially when he strained himself to speak loudest. Howbeit, she said, that at all times his voice was hoarse and low; which thing I perceived to be true. But sir, said she, you shall understand that this our vicar is diseased with such a kind of hoarseness as divers of our neighbours in this parish not long ago doubted ... and in that respect utterly refused to communicate with him until such time as (being thereunto enjoined by the ordinary) 
he had brought from London a certificate under the hands of two physicians that his hoarseness proceeded from a disease of the lungs; which certificate he published in the church, in the presence of the whole congregation: and by this means he was cured, or rather excused of the shame of the disease. And this,' certifies the narrator, 'I know to be true, by the relation of divers honest men of that parish. And truly if one of the jury had not been wiser than the others, she had been condemned thereupon, and upon other as ridiculous matters as this. For the name of witch is so odious, and her power so feared among the common people, that if the honestest body living chanced to be arraigned thereupon, she shall hardly escape condemnation.' 


\section{CHAPTER III.}

The 'Discoverie of Witcheraft,' published 1584-Wier's 'De Præstigiis Dæmonum, \&c.'-Naudé-Jean Bodin-His 'De la Démonomanie des Sorciers,' published at Paris, 1580-His authority-Nider-Witch-case at Warboys-Evidence adduced at the Trial-Remarkable as being the origin of the institution of an Annual Sermon at Huntingdon.

Three years after this affair, Dr. Reginald Scot published his 'Discoverie of Witcheraft, proving that common opinions of witches contracting with devils, spirits, or their familiars, and their power to kill, torment, and consume the bodies of men, women, and children, or other creatures, by disease, or otherwise, their flying in the air, \&c., to be but imaginary, erroneous conceptions and novelties: wherein also the. lewd, unchristian, practices of witchmongers upon aged, melancholy, ignorant, and superstitious people, in extorting confessions by inhuman terrors and tortures, is notably detected."*

* The edition referred to is that of 1654 . The author is commemorated by Hallam in terms of high praise- 'A solid and learned person, beyond almost all the English of that age.'-Introduction to the Literature of Europe in the Fifteenth, Sixteenth, and Seventeenth Centuries. 
This work is divided into sixteen books, with a treatise affixed upon devils and spirits, in thirty-four chapters. It contains an infinity of quotations from or references to the writings of those whom the author terms witch-mongers; and several chapters are devoted to a descriptive catalogue of the charms in repute and diabolical rites of the most extravagant sort. On the accession of James I., whose 'Demonologie' was in direct opposition to the 'Discoverie,' it was condemned as monstrously heretical ; as many copies as could be collected being solemnly committed to the flames. This meritorious and curious production is therefore now scarce.

Prefixed is a dedicatory epistle, addressed to the Right Worshipful, his loving friend, Mr. Dr. Coldwell, Dean of Rochester, and Mr. Dr. Readman, Archdeacon of Canterbury, in which the author appealingly expostulates, ' $\mathrm{O}$ Master Archdeacon, is it not pity that that which is said to be done with the almighty power of the Most High God, and by our Saviour his only Son Jesus Christ our Lord, should be referred to a baggage old woman's nod or wish? Good sir, is it not one manifest kind of idolatry for them that labour and are laden to come unto witches to be refreshed? If witches could help whom they are said to have made sick, I see no reason but remedy might as well be required at their hands as a purse demanded of him that hath stolen it. But 
truly it is manifest idolatry to ask that of a creature which none can give but the Creator. The papist hath some colour of Scripture to maintain his idol of bread, but no Jesuitical distinction can cover the witchmongers' idolatry in this behalf. Alas! I am ashamed and sorry to see how many die that, being said to be bewitched, only seek for magical cures whom wholesome diet and good medicine would have recovered." An utterance of courage and common sense equally rare and useless. Reginald Scot, perhaps the boldest of the early impugners of witchcraft, was yet convinced apparently of the reality of ghostly apparitions.

Johannes Wierus, physician to the Duke of Cleves, and a disciple of the well-known Cornelius Agrippa (himself accused of devotion to the black art), in 1563 created considerable sensation by an attack upon the common opinions, without questioning however the principles, of the superstition in his 'De Præstigiis Dæmonum Incantationibus et Veneficiis.' His common sense is not so clear as that of the Englishman. Another name, memorable among the advocates of Reason and Humanity, is Gabriel Naudé. He was born at Paris in 1600 ; he practised as a physician of

* Writing in an age when the magical powers of steam and electricity were yet undiscovered, it might be a forcible argument to put _ Good Mr. Dean, is it possible for a man to break his fast with you at Rochester, and to dine that day in Durham with Master Dr. Matthew ?' 
great reputation, and was librarian successively to Cardinals Richelieu and Mazarin, and to Queen Christina of Sweden. His book 'Apologie pour les Grands Hommes accusés de Magie,' published in Paris in 1625 , was received with great indignation by the Church. Some others, both on the Continent and in England, at intervals by their protests served to prove that a few sparks of reason, hard to be discovered in the thick darkness of superstition, remained unextinguished; but they availed not to stem the torrent of increasing violence and volume.

A more copious list can be given of the champions of orthodoxy and demonolatry; of whom it is sufficient to enumerate the more notorious names-Sprenger, Nider, Bodin, Del Rio, James VI., Glanvil, who compiled or composed elaborate treatises on the subject; besides whom a cloud of witnesses expressly or incidentally proclaimed the undoubted genuineness of all the acts, phenomena, and circumstances of the diabolic worship; loudly and fiercely denouncing the 'damnable infidelity' of the dissenters - a proof in itself of their own complicity. Jean Bodin, a French lawyer, and author of the esteemed treatise 'Dela République,' was one of the greatest authorities on the orthodox side. His publication 'De la Démonomanie des Sorciers' appeared in Paris in the year 1580: an undertaking prompted by his having witnessed some of the daily occurring trials. Instead of being convinced of 
their folly, he was or affected to be, certain of their truth, setting himself gravely to the task of publishing to the world his own observations and convictions.

One of the most surprising facts in the whole his tory of witcheraft is the insensibility or indifference of even men of science, and therefore observation, to the obvious origin of the greatest part of the confessions elicited; confession of such a kind as could be: the product only of torture, madness, or some other equally obvious eause. Bodin himself, however, sufficiently explains the fact and exposes the secret. ' The trial of this offence,' he enunciates, ' must not be conducted like other crimes. Whoever adheres to the ordinary course of justice perverts the spirit of the law both divine and human. He who is accused of sorcery should never be acquitted unless the malice of the prosecutor be clearer than the sun; for it is so difficult to bring full proof of this secret crime, that out of a million of witches not one would be convicted if the usual course were followed."* He speaks

* Yet the lawyer who enunciated such a maxim as this has been celebrated for an unusual liberality of sentiment in religious and political matters, as well as for his learning. Dugald Stewart commends 'the liberal and moderate riews of this philosophical politician,' as shown in the treatise De la République, and states that he knows of ' no political writer of the same date whose extensive, and various, and diseriminating reading appears to me to have contriluted more to facilitate and to guide the researches of his successors, or whose references to ancient learning have been more frequently transcribed without acknowledgment.' - Bayle considered him 'one of the ablest men that appeared in France during the sixtecnth century.'--Disser- 
of an old woman sentenced to the stake after confessing to having been transported to the sabbath in a state of insensibility. Her judges, anxious to know how this was effected, released her from her fetters, when she rubbed herself on the different parts of her body with a prepared unguent and soon became insensible, stiff, and apparently dead. Having remained in that condition for five hours, the witch as suddenly revived, relating to the trembling inquisitors a number of extraordinary things proving she must have been spiritually transported to distant places.* An earlier advocate of the orthodox cause was a Swiss friar, Nider, who wrote a work entitled 'Formicarium' (Ant-Hill) on the various sins against religion. One section is employed in the consideration of sorcery. Nider was one of the inquisitors who distinguished themselves by their successful zeal in the beginning of the century.

The Swiss witches, like the old Italian larvæ and most of the sisterhood, display extraordinary affection for the blood of new-born unbaptized infants; and it is a great desideratum to kill them before the pre-

tation First in the Encyclopedia Britannica. Hallam (Introduction to the Literature of Europe) occupies several of his pages in the review of Bodin's writings. Jean Bodin, however, on the authority of his friend De Thou, did not escape suspicion himself of being heretical.

* In witcheraft (as in the sacramental mystery) it was a subject for much doubt and dispute whether there might not be simply a spiritual (without a real corporeal) presence at the sabbath. Each one decided according to the degree of his orthodoxy. 
ventive rite has been irrevocably administered; for the bodies of unbaptized children were almost indispensable in the witches' preparations. Soon as buried their corpses are dug out of their graves and carried away to the place of assembly, where they are boiled down for the fat for making the ointments. ${ }^{*}$ The liquid in which they are boiled is carefully preserved; and the person who tastes it is immediately initiated into all the mysteries of sorcery. A witch, judicially examined by the papal commission which compiled the 'Malleus,' gives evidence of the prevalence of this practice: 'We lie in wait for children. These are often found dead by their parents; and the simple people believe that they have themselves overlain them, or that they died from natural causes; but it is we who have destroyed them. We steal them out of the grave, and boil them with lime till all the flesh is loosed from the bones and is reduced to one mass. We make of the firm part an ointment, and fill a bottle with the fluid; and whoever drinks with due ceremonies of this belongs to our league, and is already capable of bewitching.' 'Finger of birth-strangled babe' is one of the ingredients of

* A practice not entirely out of repute at the present day if we may credit a statement in the Courrier du Havre (as quoted in The Times newspaper, Nov. 7, 1864), that recently the corpse of an old woman was dug up for the purpose of obtaining the fat, \&c., as a preventive charm against witchcraft, by a person living in the neighbourhood of Harre. 
that widely-collected composition of the Macbeth witches.

The case at Warboys, which, connected with a family of some distinction, occasioned unusual interest, was tried in the year 1593. The village of Warboys, or Warbois, is situated in the neighbourhood of Huntingdon. One of the most influential of the inhabitants was a gentleman of respectability, Robert Throgmorton, who was on friendly terms with the Cromwells of Hitchinbrook, and the lord of the manor, Sir Henry Cromwell. Three criminals-old Samuel, his wife, and Agnes Samuel their daughter, were tried and condemned by Mr. Justice Fenner for bewitching Mr. Throgmorton's five children, seven servants, the Lady Cromwell, and others. The father and daughter maintained their innocence to the last; the old woman confessed. A fact which makes this affair more remarkable is, that with the forty pounds escheated to him, as lord of the manor, out of the property of the convicts, Sir Samuel Cromwell founded an annual sermon or lecture upon the sin of witchcraft, to be preached at their town every Lady-day, by a Doctor or Bachelor of Divinity of Queen's College, Cambridge; the sum of forty pounds being entrusted to the Mayor and Aldermen of Huntingdon, for a rent-charge of forty shillings yearly to be paid to the select preacher. This lecture, says Dr. Francis Hutchison, is continued to this day-1718. 
Four years previously to this important trial, Jane Throgmorton, a girl ten years of age, was first suddenly attacked with strange convulsive fits, which continued daily, and even several times in the day, without intermission. One day, soon after the first seizure, Mother Samuel coming into the Throgmortons' house, seated herself as customary in a chimneycorner near the child, who was just recovering from one of her fits. The girl no sooner noticed her than she began to cry out, pointing to the old woman, ' Did you ever see one more like a witch than she is? Take off her black-thumbed cap, for I cannot abide to look at her.' The illness becoming worse, they sent to Cambridge to consult Dr. Barrow, an experienced physician in that town; but he could discover no natural disease. A month later, the other children were similarly seized, and persuaded of Mother Samuel's guilt. The parents' increasing suspicions, entertained by the doctors, were confirmed when the servants were also attacked. About the middle of March, 1590, Lady Cromwell arrived on a visit to the Throgmortons; and being much affected at the sufferings of the patients, sent for the suspected person, whom she charged with being the malicious cause. Finding all entreaty of no avail in extorting an admission of guilt, Lady Cromwell suddenly and unexpectedly cut off a lock of the witch's hair (a powerful counter-charm), at the same time secretly 
placing it in Mrs. Throgmorton's hands, desiring her to burn it. Indignant, the accused addressed the lady, 'Madam, why do you use me thus? I never did you any harm as yet'-words afterwards recollected. 'That night,' says the narrative, 'my lady' Cromwell was suddenly troubled in her sleep by a cat which Mother S. had sent her, which offered to pluck the skin and flesh off her bones and arms. The struggle betwixt the cat and the lady was so great in her bed that night, and she made so terrible a noise, that she waked her bedfellow Mrs. C.' Whether, ' as some sager' might think, it was a nightmare (a sort of incubus which terrified the disordered imagination of the ancients), or some more substantial object that disturbed the rest of the lady, it is not important to decide; but next day Lady Cromwell was laid up with an incurable illness. Holding out obstinately against all threats and promises, the reputed witch was at length induced to pronounce an exorcism, when the afflicted were immediately for the time dispossessed. ' Next day being Christmas-eve and the Sabbath, Dr. Donington [vicar of the parish] chose his text of repentance out of the Psalms, and communicating her confession to the assembly, directed his discourse chiefly to that purpose to comfort a penitent heart that it might affect her. All sermon-time Mother S. wept and lamented, and was frequently so loud in her passions, that she drew the eyes of the congrega- 
tion upon her.' On the morrow, greatly to the disappointment of the neighbours, she contradicted her former confession, declaring it was extracted by surprise at finding her exorcism had relieved the child, unconscious of what she was saying.

The case was afterwards carried before the Bishop of Lincoln. Now greatly alarmed, the old woman made a fresh announcement that she was really a witch ; that she owned several spirits (of the nine may be enumerated the fantastic names of Pluck, Hardname, Catch, Smack, Blew), one of whom was used to appear in the shape of a chicken, and suck her chin. The mother and daughters were, upon this voluntary admission, committed to Huntingdon gaol. Of the possessed Jane Throgmorton seems to have been most familiar with the demons.*

* The following ravings of epilepsy, or of whaterer was the disorder of the girl, are part of the evidence of Dr. Donington, clergyman in the town, and were narrated and could be received as grare evidence in a court of justice. They will serve as a specimen of the rest. The girl and the spirit known as Catch are engaged in the little by-play. 'After supper, as soon as her parents were risen, she fell into the same fit again as before, and then became senseless, and in a little time, opening her mouth, she said, "Will this hold for erer? I hope it will be better one day. From whence come you now, Catch, limping? I hope you have met with your match." Cateh answered that Smack and he had been fighting, and that Smack had broken his leg. Said she, "That Smack is a shrewd fellow; methinks I would I could see him. Pluck came last night with his head broke, and now you hare broken your leg. I hope he will break both your necks before he hath done with you." Catch answered that he would be even with him before he had done. Then, said she, "Put forth 
The sessions at Huntingdon began April 4, 1593, when the three Samuels were arraigned; and the above charges, with much more of the same sort, were repeated: the indictments specifying the particular offences against the children and servants of the Throgmortons, and the 'bewitching unto death? of the lady Cromwell. The grand jury found a true bill immediately, and they were put upon their trial in court. After a mass of nonsense had been gone through, ' the judge, justices, and jury said the case was apparent, and their consciences were well satisfied that the said witches were guilty, and deserved death.' When sentence of death was pronounced, the old woman, sixty years of age, pleaded, in arrest of judgment, that she was with child-a pleading which produced only a derisive shout of laughter in court. Husband and daughter asserted their innocence to the last. All three were hanged. From the moment of execution, we are assured, Robert Throgmorton's children were permanently freed from all their sufferings. Such, briefly, are the circumstances of a witch

your other leg, and let me see if I can break that," having a stick in her hand. The spirit told her she could not hit him. "Can I not hit you?" said she; "let me try." Then the spirit put forth his leg, and she lifted up the stick easily, and suddenly struck the ground ... So she seemed divers times to strike at the spirit; but he leaped over the stick, as she said, like a Jackanapes. So after many such tricks the spirit went away, and she came out of her fit, contimuing all that night and the next day very sick and full of pain in her legs.' 
case that resulted in the sending to the gallows three harmless wretches, and in the founding an annual sermon which perpetuated the memory of an iniquitous act and of an impossible crime. The sermon, it may be presumed, like other similar surviving institutions, was preserved in the eighteenth century more for the benefit of the select preacher than for that of the people. 


\section{CHAPTER IV.}

Astrology in Antiquity-Modern Astrology and Alchymy-Torralvo-Adrentures of Dr. Dee and Edward Kelly-Prospero and Comus Types respectively of the Theurgic and Goetic Arts - Magicians on the Stage in the 16th century-Occult Science in Southern Europe-Causes of the inevitable mistakes of the pre-Scientific Ages.

THE nobler arts of magic, astrology, alchymy, necromancy, \&c., were equally in vogue in this age with that of the infernal art proper. But they were more respected. Professors of those arts were habitually sought for with great eagerness by the highest personages, and often munificently rewarded. In antiquity astrology had been peculiarly Oriental in its origin and practice. The Egyptians, and especially the Chaldæans, introduced the foreign art to the West among the Greeks and Italians; the Arabs revived it in Western Europe in the Middle Age. Under the early Roman Empire the Chaldaic art exercised and enjoyed considerable influence and reputation, if it was often subject to sudden persecutions. Augustus was assisted to the throne, and Severus selected his wife, by its means. After it had 
once firmly established itself in the West,* the Oriental astrology was soon developed and reduced to a more regular system; and in the sixteenth and seventeenth centuries Dee and Lilly enjoyed a greater reputation than even Figulus or Thrasyllus had obtained in the first century. Queen Elizabeth and Catherine di Medici (two of the astutest persons of their age) patronised them. Dr. Dee in England, and Nostradamus in France, were of this class. Dr. Caius, third founder of a college still bearing his name in the university of Cambridge, Kelly, Ashmole, and Lilly, are well-known names in the astrological history of this period. Torralvo, whose fame as an aerial voyager is immortalised by Cervantes in 'Don Quixote,' was as great a magician in Spain and Italy as Dee in England, although not so familiar to English readers as their countryman, the protégé of Elizabeth. Neither was his magical faculty so well rewarded. Dr. Torralvo, a physician, had studied medicine and philosophy with extraordinary success, and was high in the confidence of many of the eminent personages of Spain and Italy, for whom he fortunately predicted future success. A

* The diffusion and progress of astrology in the last two centuries before the Empire, in Greece and Italy, was favoured chiefly by the four following causes: its resemblance to the meteorological astrology of the Greeks; the belief in the conversion of the souls of men into stars; the cessation of the oracles; the belief in a tutelary genius.-Sir G. C. Lewis's Historical Survey of the Astronomy of the Ancients, chap. v. 
confirmed infidel or freethinker, he was denounced to the Inquisition by the treachery of an associate as denying or disputing the immortality of the soul, as well as the divinity of Christ. This was in 1529 . Torralvo, put to the torture, admitted that his informing spirit, Zequiel, was a demon by whose assistance he performed his aerial journeys and all his extraordinary feats, both of prophecy and of actual power. Some part of the severity of the tortures was remitted by the demon's opportune reply to the curiosity of the presiding inquisitors, that Luther and the Reformers were bad and cunning men. Torralvo seems to have avoided the extreme penalty of fire by recanting his beresies, submitting to the superior judgment of his gaolers, and still more by the interest of his powerful employers; and he was liberated not long afterwards.

The life of Dr. Dee, an eminent Cambridge mathematician, and of his associate Edward Kelly, forms a curious biography. Dee was born in 1527 . He studied at the English and foreign universities with great success and applause; and while the Princess Elizabeth was quite young he acquired her friendship, maintained by frequent correspondence, and on her succession to the throne the queen showed her good will in a conspicuous manner. John Dee left to posterity a diary in which he has inserted a regular account of his conjurations, prophetic intimations, and magical resources. Notwithstanding 
his mathematical acumen, he was the dupe of his cunning subordinate-more of a knave, probably, than his master. In 1583 a Polish prince, Albert Laski, visiting the English court, frequented the society of the renowned astrologer, by whom he was initiated in the secrets of the art; and predicted to be the future means of an important revolution in Europe. The astrologers wandered over all Germany, at one time favourably received by the credulity, at another time ignominiously ejected by the indignant disappointment, of a patron.* Dee returned to England in 1589, and was finally appointed to the wardenship of the college at Manchester. In James's reign he was well received at Court, his reputation as a magician increasing; and in 1604 he is found presenting a petition to the king, imploring his good offices in dispelling the injurious imputation of being ' a conjuror, or caller, or invocator of devils.' Lilly, the most celebrated magician of the seventeenth century in England, was in the highest repute during the civil wars: his prophetic 'services were sought

* While traversing Bohemia, on a particular occasion, it was rerealed to be God's pleasure that the two friends should have a community of wires; a little episode noted in Dee's journal. 'On Sunday, May 3, 1587, I, John Dee, Edward Kelly, and our two wires, corenanted with God, and subscribed the same for indissoluble unities, eharity, and friendship keeping between us four, and all things between us to be common, as God by surdry means willed us to do.' A sort of inspiration of frequent occurrenee in religious revelations, from the times of the Arabian to those of the American prophet. 
with equal anxiety by royalists and patriots, by king and parliament.* Sometimes the professor of the occult science may have been his own dupe: oftener he imposed and speculated upon the credulity of others.

Prospero is the type of the Theurgic, as Comus is of the Goetic, magician. His spiritual minister belongs to the order of good, or at least middle spirits-

'Too black for heav'n, and yet too white for hell.' $\dagger$

Prospero, by an irresistible magic, subdued to his service the reluctant Caliban, a monster ' got by the devil himself upon his wicked dam :' but that semidemon is degraded into a mere beast of burden, brutal and savage, with little of the spiritual essence of his male parent. Comus, as represented in that most beautiful drama by the genius of Milton, is of the classic rather than Christian sort: he is the true son of Circe, using his mother's method of enchantment, transforming his unwary victims into the various forms or faces of the bestial herd. Like

* William Lilly wrote a History of his own life and times. His adroitness in accommodating his prophecies to the alternating chances of the war does him considerable credit as a prophet.

† Released by his new lord from the sorceric spell of that 'damn'd witch Sycorax,' he comes gratefully, if somewhat weariedly, to answer his 'blest pleasure; be't to fly, to swim, to dire into the fire, to ride on the curl'd clouds,' \&c. 
the island magician without his magical garment, the wicked enchanter without his wand loses his sorceric power; and-

‘ Without his rod reversed, And backward mutters of dissevering power,'

it is not possible to disenchant his spell-bound prisoners.

In the sixteenth century many wonderful stories obtained of the tremendous feats of the magic art. Those that related the lives of Bacon, and of Faust (of German origin), were best known in England; and, in the dramatic form, were represented on the stage. The comedy of 'Friar Bacon and Friar Bungay,' and the tragedy of 'The Life and Death of Dr. Faustus,' are perhaps the most esteemed of the dramatic writings of the age which preceded the appearance of Shakspeare. In the latter Faustus makes a compact with the devil, by which a familiar spirit and a preternatural art are granted him for twenty-four years. At the end of this period his soul is to be the reward of the demons.* From the

* Conscious of his approaching fate, the trembling magician replies to the anxious inquiries of his surrounding pupils- "For the vain pleasure of four-and-twenty years hath Faustus lost eternal joy and felicity. I writ them a bill with my own blood; the date is expired; this is the time, and he will fetch me." First Scholar - "Why did not Faustus tell us of this before, that divines might have prayed for thee?" Faust-" Oft have I thought to have done so; but the devil threatened to tear me in pieces if I named God; to fetch me body 
'Faustus' of Christopher Marlow, Goethe has derived the name and idea of the most celebrated tragedy of our day.

Magic and necromantic prowess was equally recognised in Southern Europe. The Italian poets employed such imposing paraphernalia in the construction of an epic; and Cervantes has ridiculed the prevailing belief of his countrymen.*

and soul if I once gave ear to divinity. And now it is too late." As the fearful moment fast approaches, Dr. Faustus, orthodox on the subject of the duration of future punishment, exclaims in agony-

' Oh! if my soul must suffer for my sin,

Impose some end to my incessant pain.

Let Faustus live in hell a thousand years-

A hundred thousand, and at the last be sared:

No end is limited to damned souls.

Why wert thou not a creature wanting soul?

Oh, why is this immortal that thou hast?' \&e.

Mephistopheles, it need hardly be added, was on this occasion true to his reputation for punctuality. Friar Bacon and Friar Bungay is remarked for being one of the last dramatic pieces in which the devil appears on the stage in his proper person-1591. It is also noticeable that he is the only Scripture character in the new form of the play retained from the miracles which delighted the spectators in the fifteenth century, who were at once edified and gratified by the corporal chastisement inflicted upon his vicarious back.

* Benvenuto Cellini, the Florentine engraver, in his amusing Autobiography, astonishes his readers with some necromantic wonders of which he was an eyewitness. Cellini had become acquainted and enamoured with a beautiful Sicilian, from whom he was suddenly separated. He tells with his accustomed candour and confidence, 'I was then indulging myself in pleasures of all sorts, and engaged in another amour to cancel the memory of my Sicilian mistress. It happened, through a variety of odd accidents, that I made acquaintance with a Sicilian priest, who was a man of genius, and well versed 


\section{Alchymy, the science of the transformation of baser} metals into gold, a pursuit which engaged the anxious

in the Latin and Greek authors. Happening one day to hare some conversation with him upon the art of necromancy, I, who had a great desire to know something of the matter, told him I had all my life felt a curiosity to be acquainted with the mysteries of this art. The priest made answer that the man must be of a resolute and steady temper who enters upon that study.' And so it should seem from the event. One night, Cellini, with a companion familiar with the Black Art, attended the priest to the Colosseum, where the latter, ' according to the custom of necromancy, began to draw marks upon the ground, with the most impressive ceremonies imaginable; he likewise brought thither asafoetida, several precious perfumes and fire, with some compositions which diffused noisome odours.' Although several legions of devils obeyed the summons of the conjurations or compositions, the sorceric rites were not attended with complete success. But on a succeeding night, 'the necromancer having begun to make his tremendous invocations, called by their names a multitude of demons who were the leaders of the several legions, and invoked them by the virtue and power of the eternal uncreated God, who lives for ever, insomuch that the amphitheatre was almost in an instant filled with demons a hundred times more numerous than at the former conjuration ... I I, by the direction of the necromancer, again desired to be in the company of my Angelica. The former thereupon turning to me said, "Know that they have declared that in the space of a month you shall be in her company." He then requested me to stand resolutely by him, because the legion were now above a thousand more in number than he had designed; and besides, these were the most dangerous, so that after they had answered my question it behoved him to be civil to them and dismiss them quietly.' The infernal legions were more easily eroked than dismissed. He proceeds - 'Though I was as much terrified as any of them, I did my utmost to conceal the terror I felt; so that I greatly contributed to inspire the rest with resolution. But the truth is,' ingenuously confesses the amorous artist, ' $I$ gave myself orer for a dead man, seeing the horrid fright the necromancer was in.'-Autobiography of Benvenuto Cellini, chap. xiii., Roscoe's transl.-The information was rerified, and Benvenuto enjoyed the society of his mistress at the time foretold. 
thought and wasted the health, time, and fortunes of numbers of fanatical empirics, was one of the most prized of the abstruse occult arts. Monarchs, princes, the great of all countries, eagerly vied among themselves in encouraging with promises and sometimes with more substantial incentives the zeal of their illusive search; and Henry IV. of France could see no reason why, if the bread and wine were transubstantiated so miraculously, a metal could not be transformed as well.*

Among the eminent names of self-styled or reputed masters of the nobler or white magic, some, like the celebrated Paracelsus, were men of extraordinary attainments and largely acquainted with the secrets of natural science. A necessarily imperfect knowledge, a natural desire to impose upon the ignorant wonder of the vulgar, and the vanity of a learning which was

* The class of horoscopists (the old Chaldaic genethliacs), or those who predicted the fortunes of individuals by an examination of the planet which presided at the natal hour, was as much in rogue as that of any other of the masters of the occult arts; and La Fontaine, towards the end of the seventeenth century, apostrophises the class:

' Charlatans, faiseurs d'horoscope!

Quittez les cours des princes de l'Europe;

Emmenez avec vous les souffleurs tout d'un temps;

Vous ne méritez pas plus de foi.' . . . .

Fables, ii. 13.

But it is only necessary to recollect the name of Cagliostro (Balsamo) and others who in the eighteenth century could successfully speculate upon the credulity of people of rank and education, to moderate our wonder at the success of earlier empirics. 
ambitious of exhibiting, in the most imposing if less intelligible way, their superior knowledge, were probably the mixed causes which led such distinguished scholars as Paracelsus, Cornelius Agrippa, Cardan, and Campanella to oppress themselves and their readers with a mass of unintelligible rubbish and cabalistic mysticism.* Slow and gradual as are the successive advances in the knowledge and improvement of mankind, it would not be reasonable to be surprised that preceding generations could not at once attain to the knowledge of a maturer age; and the teachers of mankind groped their dark and uncertain way in ages destitute of the illumination of modern times. $\dagger$

\section{* 'Cardan believed great states depend Upon the tip o' th' Bear's tail's end,'}

correctly enough expresses both the persuasion of the public and that of many of the soi-disant philosophers of the intimate dependence of the fates of both states and individuals of this globe upon other globes in the unirerse.

+ It was not so much a want of sufficient observation of known facts, as the want of a true method and of verification, which rendered the investigations of the earlier philosophers so rague and uncertain. And the same causes which necessarily prevented Aristotle, the greatest intellect perhaps that has ever illuminated the world, from attaining to the greater perfection of the modern philosophy, are applicable, in a greater degree, to the case of the mediæral and later discoverers. The causes of the failure of the pre-scientific world are well stated by a living writer. 'Men cannot, or at least they will not, await the tardy results of discovery ; they will not sit down in avowed ignorance. Imagination supplies the deficiencies of observation. A theoretic arch is thrown across the chasm, because men are unwilling to wait till a solid bridge be constructed ... The 
early thinkers, by reason of the very splendour of their capacities, were not less incompetent to follow the slow processes of scientific investigation, than a tribe of martial savages to adopt the strategy and discipline of modern armies. No accumulated laws, no well-tried methods existed for their aid. The elementary laws in each department were mostly undetected.' The guide of knowledge is verification. 'The complexity of phenomena is that of a labyrinth, the paths of which cross and recross each other; one wrong turn causes the wanderer infinite perplexity. Verification is the Ariadne-thread by which the real issues may be found. Unhappily, the process of rerification is slow, tedious, often difficult and deceptive; and we are by nature lazy and impatient, hating labour, eager to obtain. Hence credulity. We accept facts without scrutiny, inductions without proof; and we yield to our disposition to believe that the order of phenomena must correspond with our conceptions.' A profound truth is contained in the assertion of Comte (Cours de Philosophie Positive) that ' men have still more need of method than of doctrine, of education than of instruction.'-Aristotle, by G. H. Lewes. 


\section{CHAPTER V.}

Sorcery in Southern Europe-Cause of the Retention of the Demonological Creed among the Protestant Sects-Calrinists the most Fanatical of the Reformed Churches - Witch-Creed sanctioned in the Authorised Version of the Sacred Scriptures -The Witch-Act of 1604-James VI.'s 'Demonologie'- Lycanthropy and Executions in France-The French Provincial Parliaments active in passing Laws against the various Witchpractices-Witcheraft in the Pyrenees-Commission of Inquiry appointed-Its Results-Demonology in Spain.

In the annals of black magic, the silent tribunals of the Inquisition in Southern Europe which has consigned so many thousands of heretics to the torture room and to the flames, do not reveal so many trials for the simple crime of witchcraft as the tribunals of the more northern peoples: there all dissent from Catholic and priestly dogma was believed to be inspired by the powers of hell, deserving a common punishment, whether in the form of denial of transubstantiation, infallibility, of skill in magic, or of the vulgar practice of sorcery. Throughout Europe penalties and prosecutions were being continually enacted. The popes in Italy fulminated abroad their decrees, and the parliaments of France were almost daily engaged in pronouncing sentence. 
Where the papal yoke had been thrown off in Northern Germany, in Scotland, and in England, the belief and the persecution remained in full force, indeed greatly increased; and it is obvious to inquire the cause of the retention, with many additions, of the doctrine of witcheraft by those who had at last finally rejected with scorn most of the grosser religious dogmas of the old Church, who were so loud in their just denunciation of Catholic tyranny and superstition. A general answer might be given that the Reformation of the sixteenth century, while it swept away in those countries in which it was effected the most injurious principles of ecclesiasticism, the principles of infallibility and authority in matters of faith, for the destruction of which gratitude is due to the independent minds of Luther, Zuinglius, and others, was yet far from complete in its negations. The leaders of that great revolution, with all their genius and boldness, could only partially free themselves from the prejudices of education and of the age. To develope the important principles they established, the rights of private judgment and religious freedom, was the legacy and duty of their successors; a duty which they failed to perform, to the incalculable misfortune of succeeding generations. The Sacred Scriptures, the common and only authority on faith among the different sections of Protestantism, unfortunately seemed to inculcate the dread power 
of the devil and his malicious purposes, and both the Jewish and Christian Scriptures apparently taught 1 the reality of witchcraft. Theologians of all parties would have as easily dared to question the existence of God himself as to doubt the actual power of that other deity, and the unbelievers in his universal interference were not illogically stigmatised as atheists. With the Protestants some adventitious circumstances might make a particular church more fanatical and furious than another, and the Calvinists. have deserved the palm for the bitterest persecution of witcheraft. But neither the Lutheran nor the Anglican section is exempt from the odious imputation.*

The followers of Calvin were most deeply imbued with hatred and horror of Catholic practices, and, adopting the old prejudice or policy of their antagonists, they were willing to confound the superstitious rites of Catholicism with those of demonolatry. The Anglican Church party, whose principles were not so entirely opposite to the old religion, had far less antipathy: until the revolution of 1688 it was for the most part engaged in contending against liberty rather than against despotism of conscience; against

* Lord Peter, and his humbler brothers Martin and Jack, in different degrees, are all of them obnoxious to the accusation; and Bossuet (Variations des Eglises Protestantes, xi. 201), who is assured that St. Paul predicted the 'doctrines of devils' to be characteristic of Manichæan and Albigensian heresy, might hare more safely interpreted the prophecy as applicable to the unirersal Christian Church (at least of Western Europe) of the sixteenth and seventeenth centuries. 
Calvinism than against Catholicism. Yet the Church of England is exposed to the reproach of having sanctioned the common opinions in the most authoritative manner. In the authorised version of the Sacred Scriptures, in the translation of which into the English language forty-seven selected divines, eminent for position and learning, could concur in consecrating a vulgar superstition, the most imposing sanction was given. Had they possessed either common sense or courage, these Anglican divines might have expressed their disbelief or doubt of its truth by a more rational, and possibly more proper, interpretation of the Hebrew and Greek expressions; or if that was not possible, by an accompanying unequivocal protest. But the subservience as well as superstition of the English Church under the last of the Tudors and under the Stuarts is equally a matter of fact and of reprobation.

It was in the first year of the first King of Great Britain that the English Parliament passed the Act which remained in force, or at least on the Statute Book, until towards the middle of last century.*

* The 'Witch Act' of James I. was passed in the year 1604. The new translation, or the present authorised rersion, of the Bible, was executed in 1607. The inference seems plain. An ecelesiastical eanon passed at the same period, which prohibits the inferior clergy from exorcising without episcopal licence, proves at the same time the prevalence of 'possession' and the prevalence of exorcism in the beginning of the seventeenth century. 
After due consideration the bill passed both Houses; and by it, it was enacted that 'If any person shall use any invocation or conjuration of any evil or wicked spirit, or shall consult, covenant with, entertain, employ, feed, or reward any evil or cursed spirit to or for any intent or purpose, or take up any dead man, woman, or child out of the grave-or the skin, bone, or any part of the dead person, to be employed or used in any manner of witchcraft, sorcery, charm, or enchantment; or shall use, exercise, or practice any sort of witchcraft, \&c., whereby any person shall be destroyed, killed, wasted, consumed, pined or lamed in any part of the body; that every such person being convicted shall suffer death.' Twelve bishops sat in the Committee of the Upper House.*

The Scottish Parliament, during Queen Mary's reign, anathematised the papistical practices; and from that time the annals of Scottish judicature are filled with records of trials and convictions. James was educated among the stern adherents of Calvin. In whatever matters of ecclesiastical faith and rule the countryman of Knox may have deviated from the teaching of his preceptors, he maintained with constant zeal his faith in the devil's omnipotence; and we may be disposed to concede the title of 'Defender

* The parliament of James I. would hare done wisely to hare embraced the philosophic sentiment of a Hungarian prince (1095-1114) who is said to have dismissed the absurd superstition with laconic brevity: 'De strigis vero, qure non sunt, nulla quxstio fiat.' 
of the Faith' (so confidently prefixed to successive editions of the Authorised Version) to his activity in the extermination of witches, rather than to his hatred of priestcraft. While monarch only of the Northern kingdom, he published a denunciation of the damnable infidelity of the 'Witch Advocates,' and his own unhesitating belief. James VI. and his clerical advisers were persuaded, or affected to be persuaded, that the devil, with all his hellish crew, was conspiring to frustrate the beneficial intentions of a pious Protestant prince. Infernal despair and rage reached the climax when the marriage with the Danish princess was to be effected. But, far from being terrified by so formidable a conspiracy, he gloried in the persuasion that he was the devil's greatest enemy; and the man who shuddered at the sight of a drawn sword was not afraid to enter the lists against the invisible spiritual enemy.

The 'Demonologie' was published at Edinburgh in 1597. The author introduces his book with these words: 'The fearful abounding at this time in this country of these detestable slaves of the devil, the witches or enchanters, hath moved me (beloved reader) to despatch in post this following treatise of mine, not in any wise (as I protest) to serve for a show of my learning and ingine, but only moved of conscience to press thereby so far as I can to resolve the doubting hearts of many; both that such assaults 
of Sathan are most certainly practised, and that the instruments thereof merits most severely to be punished: against the damnable opinions of two principally in our age, whereof the one called Scot, an Englishman, is not ashamed in public print to deny that there can be such a thing as witchcraft, and so maintains the old error of the Sadducees in denying of spirits. The other, called Wierus, a German physician, sets out a public apology for all these crafts-folks, whereby procuring for their impunity, he plainly bewrays himself to have been one of that profession. And for to make this treatise the more pleasant and facile, I have put it in form of a dialogue, which I have divided into three books: the first speaking of magic in general, and necromancy in special; the second, of sorcery and witchcraft; and the third contains a discourse of all those kinds of spirits and spectres that appears and troubles persons, together with a conclusion of the whole work. My intention in this labour is only to prove two things, as I have already said: the one, that such devilish arts have been and are; the other, what exact trial and severe punishment they merit; and therefore reason I what kind of things are possible to be performed in these arts, and by what natural causes they may be. Not that I touch every particular thing of the devil's power, for that were infinite; but only, to speak scholasticly (since this cannot be spoken 
in our language), I reason upon genus, leaving species and differentia to be comprehended therein." *

The following injunction is characteristic of all persecuting maxims, and is worthy of the disciple of Bodin: 'Witches ought to be put to death according to the law of God, the civil and the imperial law, and the municipal law of all Christian nations. Yea, to spare the life and not to strike whom God bids strike, and so severely in so odious a treason against God, is not only unlawful but doubtless as great a sin in the magistrate as was Saul's sparing Agag.' It is insisted upon by this sagacious author (echoing the

* Speculating on the manner of witches' aerial travels, he thinks, 'Another way is somewhat more strange, and yet it is possible to be true: which is, by being carried by the force of their spirit, which is their conductor, either above the earth or above the sea swiftly to the place where they are to meet: which I am persuaded to be likewise possible, in respect that as Habakkuk was carried by the angel in that form to the den where Daniel lay, so think I the devil will be ready to imitate God as well in that as in other things, which is much more possible to him to do, being a spirit, than to a mighty wind, being but a natural meteor to transport from one place to another a solid body, as is commonly and daily seen in practice. But in this violent form they cannot be carried but a short bounds, agreeing with the space that they may retain their breath; for if it were longer their breath could not remain unextinguished, their body being earried in such a violent and forcible manner. . . And in this transporting they say themselves that they are invisible to any other, except amongst themselves. For if the devil may form what kind of impressions he pleases in the air, as I have said before, speaking of magic, why may he not far easier thieken and obscure so the air that is next about them, by contracting it straight together that the beams of any other man's eyes cannot pierce through the same to see them ?' \&c. - Cyclopedia of English Literature, edited by Robert Chambers. 
rules laid down in the 'Malleus'), that any and every evidence is good against an exceptional crime: that the testimony of the youngest children, and of persons of the most infamous character, not only may, but ought to be, received.

This mischievous production is a curions collection of demonological learning and experience, exhibiting the reputed practices and ceremonies of witches, the mode of detecting them, \&c.; but is useless even for the purpose of showing the popular Scottish or English notions, being chiefly a medley of classical or foreign ideas, inserted apparently (spite of the royal author's assurance to the contrary) to parade an array of abstruse and pedantic learning. That some of the excessive terror said to have been exhibited was simulated to promote his pretensions to the especial hostility of Satan, is probable : but that also he was impressed, in some degree, with a real and lively fear scarcely admits of doubt. The modern Solomon might well have blushed at the superior common sense of a barbaric chief; and the 'judges of the seventeenth century might have been instructed and confounded at the superior wisdom of Rotharis [a Lombardic prince], who derides the absurd superstition and protects the wretched victims of popular or judicial cruelty.' *

* Decline and Fall of the Roman Empire, xlv. It would have been well for his subjects if he could have congratulated himself, like 
Previously to the 'Witch Act,' the charge of sorcery was, in most cases, a subordinate and subsidiary one, attached to various political or other indictments. Henceforward the practice of the peculiar offence might be entirely independent of any more substantial accusation. In England, compared with the other countries of Europe, folly more than ferocity, perhaps, generally characterises the proceedings of the tribunals. During the pre-Reformation ages, France, even more than her island neighbour, suffered from the crime. The fates of the Templars, of Jeanne d'Arc, of Arras, of those suspected of causing the mad king's, Charles VI., derangement (when many of the white witches, or wizards, 'mischievously good,' suffered for failing, by a pretended skill, to effect his promised cure) are some of the more conspicuous examples. But in France, as in the rest of Europe, it was in the post-feudal period that prosecutions became of almost daily occurrence.

A prevalent kind of sorcery was that of lycanthropy, as it was called, a prejudice derived, it seems, in part from the Pythagorean metempsychosis. A few cases will illustrate the nature of this stupendous

Marcus Aurelius Antoninus (the model of philosophic princes, and a more practically virtuous, if not wiser, philosopher than the proverbial Solomon, and of whom Niebuhr, History of Rome, v., asserts, 'If there is any sublime human virtue, it is his '), that he had learnt from his instructors to laugh at the bugbears of witches and de-

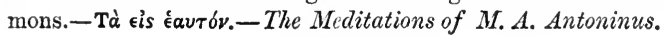


transformation. That it is mostly found to take place in France and in the southern districts, the country of wolves, that still make their ravages there, is a fact easily intelligible; and if the devil can enter into swine, he can also, in the opinion of the demonologists, as easily enter into wolves. At Dôle, in 1573, a loup-garou, or wehr-wolf (man-wolf), was accused of devastating the country and devouring little children. The indictment was read by Henri Camus, doctor of laws and counsellor of the king, to the effect that the accused, Gilles Garnier, had killed a girl twelve years of age, having torn her to pieces, partly with his teeth, and partly with his wolf's paws; that having dragged the body into the forest, he there devoured the larger portion, reserving the remainder for his wife; also that, by reason of injuries inflicted in a similar way on another young girl, the loup-garou had occasioned her death; also that he had devoured a boy of thirteen, tearing him limb by limb; that he displayed the same unnatural propensities even in his own proper shape. Fifty persons were found to bear witness; and he was put to the rack, which elicited an unreserved confession. He was then brought back into court, when Dr. Camus, in the name of the Parliament of Dôle, pronounced the following sentence: 'Seeing that Gilles Garnier has, by the testimony of credible witnesses and by his own spontaneous confession, 
been proved guilty of the abominable crimes of lycanthropy and witcheraft, this court condemns him, the said Gilles, to be this day taken in a cart from this spot to the place of execution, accompanied by the executioner, where he, by the said executioner, shall be tied to a stake and burned alive, and that his ashes be then scattered to the winds. The court further condemns him, the said Gilles, to the costs of this prosecution. Given at Dôle this 18th day of January, 1573.' Five years later a man named Jacques Rollet was burned alive in the Place de Grêve for the same crime, having been tried and condemned by the Parliament of Paris.*

* A still more sensational case happened at a village in the mountains of Auvergne. A gentleman while hunting was suddenly attacked by a savage wolf of monstrous size. Impenetrable by his shot, the beast made a spring upon the helpless huntsman, who in the struggle luckily, or unluckily for the unfortunate lady, contrived to cut off one of its fore-paws. This trophy he placed in his pocket, and made the best of his way homewards in safety. On the road he met a friend to whom he exhibited a bleeding paw, or rather a woman's hand (so it was produced from the hunter's pocket) upon which was a wedding ring. His wife's ring was at once recognised by the other. His suspicions aroused, he immediately went in search of his wife, who was found sitting by the fire in the kitchen, her arm hidden beneath her apron: when the husband seizing her by the arm found his terrible suspicions verified. The bleeding stump was there, evidently just fresh from the wound. She was given into custody, and in the event was burned at Riom in presence of thousands of spectators. Among some of the races of India, among the Khonds of the mountains of Orissa, a superstition obtains like that of the loup-garou of France. In India the tiger takes the place of the wolf, and the metamorphosed witch is there known as the Pulta-bag.

A kindred prejudice, Vampirism, has still many adherents in 
Several witches were burned in successive years throughout the kingdom. In 1564, three witches and a wizard were executed at Poictiers : on the rack they declared that they had destroyed numbers of sheep by magical preparations, attended the Sabbaths, \&c. Trois Echelles, a celebrated sorcerer, examined in the presence of Charles IX. and his court, acknowledged his obligation to the devil, to whom he had sold himself, recounting the debaucheries of the Sabbath, the methods of bewitehing, and the compositions of the unguents for blighting cattle. The astounding fact was also revealed that some twelve hundred accomplices were at large in different parts of the land. The provincial parliaments in the end of this and the greater part of the next century are unremittingly engaged in passing decrees and making provisions against the increasing offences." "The

Eastern Europe. The rampire is a human being who in his tomb maintains a posthumous existence by ascending in the night and sucking the bodies of the living. His punishment was necessarily less tremendous than that of the witch: the dead body only being burned to ashes. An official document, quoted by Horst, narrates the particulars of the examination and burning of a disinterred rampire.

* Montaigne, one of the few Frenchmen at this time who seemed to discredit the unirersal creed, in one of his essays ventures to think 'it is very probable that the principal credit of risions, of enehantments, and of such extraordinary effects, proceeds from the power of the imagination acting principally upon the more impressible minds of the vulgar.' He is inclined to assign the prevalent 'liaisons' (nouements d'aiguillettes) to the apprehensions of a fear with which in his age the French world was so perplexed (si entravé). Essais, liv. i. 20. 
Parliament of Rouen decreed that the possession of a grimoire or book of spells was sufficient evidence of witchcraft; and that all persons on whom such books were found should be burned alive. Three councils were held in different parts of France in 1583, all in relation to the same subject. The Parliament of Bordeaux issued strict injunctions to all curates and clergy whatever to use redoubled efforts to root out the crime of witcheraft. The Parliament of Tours was equally peremptory, and feared the judgments of an offended God if all these dealers with the devil were not swept from the face of the land. The Parliament of Rheims was particularly severe against the noueurs d'aiguillettes or 'tiers of the knot'-people of both sexes who took pleasure in preventing the consummation of marriage that they might counteract the command of God to our first parents to increase and multiply. This parliament held it to be sinful to wear amulets to preserve from witchcraft; and that this practice might not be continued within its jurisdiction, drew up a form of exorcism 'which could more effectually defeat the agents of the devil and put them to flight." ${ }^{*}$

In France, and still more in Italy, there is reason for believing that many of the convicts were not

* Extraordinary Popular Delusions, by Mackay, whose authorities are Tablier, Boguet (Discours sur les Sorciers), and MI. Jules Garinet (Histoire de la Magie). 
without the real guilt of toxicological practices; and they might sometimes properly deserve the opprobrium of the old venefici. The formal trial and sentence to death of La Maréchale de l'Ancre in 1617 was perbaps more political than superstitious, but witchcraft was introduced as one of the gravest accusations. Her preponderance in the councils of Marie de Medici and of Louis XIII. originated in the natural fascination of royal but inferior minds. Two years afterwards occurred a bonâ fide prosecution on a large scale. A commission was appointed by the Parliament of Bordeaux to inquire into the causes and circumstances of the prevalence of witcheraft in the Pyrenean districts. Espaignol, president of the local parliament, with the better known councillor, Pierre de l'Ancre, who has left a record ('Tableau de l'Inconstance des Mauvais Anges et Démons, où il est amplement traité des Sorciers et Démons : Paris '), was placed at the head of the commission. How the district of Labourt was so infested with the tribe, that of thirty thousand inhabitants hardly a family existed but was infected with sorcery, is explained by the barren, sterile, mountainous aspect of the neighbourhood of that part of the Pyrenees: the men were engaged in the business of fishermen, and the women left alone were exposed to the tempter. The priests too were as ignorant and wicked as the people; their relations with the lonely wives and 
daughters being more intimate than proper. Young and handsome women, some mere girls, form the greater proportion of the accused. As many as forty a day appeared at the bar of the commissioners, and at least two hundred were hanged or burned.

Evidence of the appearance of the devil was various and contradictory. Some at the Domdaniel, the place of assemblage, had a vision of a hideous wild he-goat upon a large gilded throne; others of a man twisted and disfigured by Tartarean torture; of a gentleman in black with a sword, booted and spurred; to others heseemed as some shapeless indistinct object, as that of the trunk of a tree, or some huge rock or stone. They proceeded to their meetings riding on spits, pitchforks, broom-sticks : being entertained on their arrival in the approved style, and indulging in the usual licence. Deputies from witchdom attended from all parts, even from Scotland. When reproached by some of his slaves for failing to come to the rescue in the torture-chamber or at the stake, their lord replied by causing illusory fires to be lit, bidding the doubters walk through the harmless flames, promising not more inconvenience in the bonfires of their persecutors. Lycanthropic criminals were also brought up who had prowled about and devastated the sheepfolds. Espaignol and De l'Ancre were provided with two professional Matthew Hopkinses: one a 
surgeon for examining the 'marks' (generally here discovered in the left eye, like a frog's foot) in the men and older women; the other a girl of seventeen, for the younger of her sex. Many of the priests were executed; several made their escape from the country. Besides the work before mentioned, De l'Ancre published a treatise under the title of ' L'Incrédulité et Mescréance du Sortilége pleinement convaincue,' 1622. The expiration of the term of the Bordeaux commission brought the proceedings to a close, and fortunately saved a number of the condemned.

In Spain, the land of Torquemada and Ximenes, which had long ago fanatically expelled the Jews and recently its old Moorish conquerors from its soil, the unceasing activity of the Inquisition during 140 years must have extorted innumerable confessions and proofs of diabolic conspiracies and heresy. Antonio Llorente, the historian of the Inquisition, to whose rare opportunities of obtaining information we are indebted for some instructive revelations, has exposed a large number of the previously silent and dark transactions of the Holy Office. But the demonological ideas of the Southern Church and people are profusely displayed in the copious drarnatic literature of the Spaniards, whose theatre was at one time nearly as popular, if not as influential, as the Church. 
The dramas of the celebrated Lope de Vega and of Calderon in particular, are filled with demons as well as angels*-a sort of religious compensation to the Church for the moral deficiencies of a licentious stage, or rather licentious public.

* In the Nacimiento de Christo of Lope de Vega the devil appears in his popular figure of the dragon. Calderon's Wonder-Working Magician, relating the adventures of St. Cyprian and the various temptations and seductions of the Evil Spirit, like Goethe's Faust, introduces the devil in the disguise of a fashionable and gallant gentleman.-Ticknor's History of Spanish Literature. 


\section{CHAPTER VI.}

'Possession' in France in the Seventeenth Century-Urbain Grandier and the Convent of Loudun - Exorcism at AixEcstatic Phenomena-Madeleine Bavent-Her cruel Persecution-Catholic and Protestant Witcheraft in GermanyLuther's Demonological Fears and Experiences-Originated in his exceptional Position and in the extraordinary Circumstances of his Life and Times-Witch-burning at Bamburg and at Würzburg.

Demoniacal possession was a phase of witchcraft which obtained extensively in France during the seventeenth century: the victims of this ballucination were chiefly the female inmates of religious houses, whose inflamed imaginations were prostituted by their priestly advisers to the most atrocious purposes. Urbain Grandier's fate was connected with that of an entire convent. The facts of this celebrated sorcerer's history are instructive. He was educated in a college of the Jesuits at Bordeaux, and presented by the fathers, with whom his abilities and address had gained much applause, to a benefice in Loudun. He provoked by his haughtiness the jealousy of his brother clergy, who regarded him as an intruder, and his pride and resentment increased 
in direct proportion to the activity of his enemies, who had conspired to effect his ruin. Mounier and Mignon, two priests whom he had mortally offended, were most active. Urbain Grandier was rash enough to oppose himself alone to the united counsels of unscrupulous and determined foes. Defeated singly in previous attempts to drive him from Loudun, the two priests combined with the leading authorities of the place. Their haughty and careless adversary had the advantage or disadvantage of a fine person and handsome face, which, with his other recommendations, gained him universal popularity with the women; and his success and familiarities with the fair sex were not likely to escape the vigilance of spies anxious to collect damaging proofs. What inflamed to the utmost the animosities of the two parties was the success of Canon Mignon in obtaining the coveted position of confessor to the convent of Ursulines in Loudun, to the exclusion of Grandier, himself an applicant. This convent was destined to assume a prominent part in the fate of the curé of the town. The younger nuns, it seems, to enliven the dull monotony of monastic life, adopted a plan of amusing their leisure by frightening the older ones in making the most of their knowledge of secret passages in the building, playing off ghosttricks, and raising unearthly noises. When the newly appointed confessor was informed of the state of 
matters he at once perceived the possibility, and formed the design, of turning it to account. The offending nuns were promised forgiveness if they would continue their ghostly amusement, and also affect demoniacal possession; a fraud in which they were more readily induced to participate by an assurance that it might be the humble means of converting the heretics-Protestants being unusually numerous in that part of the country.

As soon as they were sufficiently prepared to assume their parts, the magistrates were summoned to witness the phenomena of possession and exorcism. On the first occasion the Superior of the convent was the selected patient; and it was extracted from the demon in possession that he had been sent by Urbain Grandier, priest of the church of St. Peter. This was well so far; but the civil authorities generally, as it appears, were not disposed to accept even the irrefragable testimony of a demoniac; and the ecclesiastics, with the leading inhabitants, were in conflict with the civil power. Opportunely, however, for the plan of the conspirators, who were almost in despair, an all-powerful ally was enlisted on their side. A severe satire upon some acts of the minister of France, Cardinal Richelieu, or of some of his subordinates, had made its appearance. Urbain was suspected to be the author; his enemies were careful to improve the occasion; and the Cardinal- 
minister's cooperation was secured. A royal commission was ordered to inquire into the now notorious circumstances of the Loudun diabolism. Laubardemont, the head of the commission, arrived in December 1633 , and no time was lost in bringing the matter to a crisis. The house of the suspected was searched for books of magic; he himself being thrown into a dungeon, where the surgeons examined him for the 'marks.' Five insensible spots were found-a certain proof. Meanwhile the nuns become more hysterical than ever; strong suspicion not being wanting that the priestly confessors to the convent availed themselves of their situation to abuse the bodies as well as the minds of the reputed demoniacs. To such an extent went the audacity of the exorcists, and the credulity of the people, that the enceinte condition of one of the sisters, which at the end of five or six months disappeared, was explained by the malicious slander of the devil, who had caused that scandalous illusion. Crowds of persons of all ranks flocked from Paris and from the most distant parts to see and hear the wild ravings of these hysterical or drugged women, whose excitement was such that they spared not their own reputations; and some scandalous exposures were submitted to the amusement or curiosity of the surrounding spectators. Some few of them, aroused from the horrible delusion, or ashamed of their complicity, admitted that all their previous 
revelations were simple fiction. Means were found to effectually silence such dangerous announcements. The accusers pressed on the prosecution; the influence of his friends was overborne, and Grandier was finally sentenced to the stake. Fearing the result of a despair which might convincingly betray the facts of the case to the assembled multitude, they seem to have prevailed upon the condemned to keep silence up to the last moment, under promise of an easier death. But already fastened to the stake, he learned too late the treachery of his executioners ; instead of being first strangled, he was committed alive to the flames. Nor were any ' last confessions' possible. The unfortunate victim of the malice of exasperated rivals, and of the animosity of the implacable Richelieu, has been variously represented.* It is noticeable that the scene of this affair was in the heart of the conquered Protestant region-Rochelle had fallen only six years before the execution; and the heretics, although politically subdued, were numerous and active. A fact which may account for the seeming indifference and even the opposition of a large number of the people in this case of dia-

* Michelet apparently accepts the charge of immorality ; according to which the cure took advantage of his popularity among the ladies of Loudun, by his insinuating manners, to seduce the wives and daughters of the citizens. By another writer (Alexandre Dumas, Celebrated Crimes) he is supposed to have been of a prond and rindictive disposition, but innocent of the alleged irregularities. 
bolism which obtained comparatively little credit. It had been urged to the nuns that it would be for the good and glory of Catholicism that the heretics should be confounded by a few astounding miracles. Whether Grandier had any decided heretical inclinations is doubtful; but he wrote against the celibacy of the priesthood, and was suspected of liberal opinions in religion. A Capuchin named Tranquille (a contemporary) has furnished the materials for the 'History of the Devils of Loudun' by the Protestant Aubin, 1716.

Twenty-four years previously a still more scandalous affair-that of Louis Gauffridi and the Convent of Aix, in which Gauffridi, who had debauched several girls both in and out of the establishment, was the principal actor-was transacted with similar circumstances. Madeleine, one of the novices, soon after entering upon her noviciate, was seized with the ecstatic trances, which were speedily communicated to her companions.* These fits, in the judgment of the priests, were nothing but the effect of witchcraft. Exorcists elicited from the girls that

* M. Maury, in a philosophical and learned work (La Magie et l'Astrologie dans l'Antiquité et au Moyen Âge), has scientifically explored and exposed the mysteries of these and the like ecstatic phenomena, of such frequent occurrence in Protestant as well as in Catholic countries; in the orphan-houses of Amsterdam and Horn, as well as in the convents of France and Italy in the 17th century. And the Protestant revivalists of the present age have in great measure reproduced these curious results of religious excitement. 
Louis Gauffridi, a powerful magician having authority over demons throughout Europe, had bewitched them. The questions and answers were taken down, by order of the judges, by reporters, who, while the priests were exorcising, committed the results to writing, published afterwards by one of them, Michaelis, in 1613. Among the interesting facts acquired through these spirit-media, the inquisitors learned that Antichrist was already come; that printing, and the invention of it, were alike accursed, and similar information. Madeleine, tortured and imprisoned in the most loathsome dungeon, was reduced to such a condition of extreme horror and dread, that from this time she was the mere instrument of her atrocious judges. Having been intimate with the wizard, she could inform them of the position of the 'secret marks' on his person: these were ascertained in the usual way by pricking with needles. Gauffridi, by various torture, was induced to make the required confession, and was burned alive at Aix, April 30, 1611.

Demoniacal possession was a mania in France in the seventeenth century. The story of Madeleine Bavent, as reported, reveals the utmost licentiousness and fiendish cruelty.* Gibbon justly ob-

* It is but one instance of inuumerable amours within the secret penetralia of the privileged conrentual establishments. In the dark recesses of these restal institutions on a gigantic scale, where 
serves that ancient Rome supported with the greatest difficulty the institution of six vestals, notwithstanding the certain fate of a living grave for those who could not preserve their chastity; and Christian Rome was filled with many thousands of both sexes bound by vows to perpetual virginity. Madeleine was seduced by her Franciscan confessor when only fourteen; and she entered a convent lately founded at Louviers. In this building, surrounded by a wood, and situated in a suitable spot, some strange practices were carried on. At the in-

publicity, that sole security, was never known, what vices or even crimes could not be safely perpetrated? Luther, who proved in the most practical way his contempt for the sauctity of monastic rows by eloping with a nun, assures us, among other seandals attaching to convent life, of the fact that when a fish-pond adjoining one of these establishments in Rome was drained off, six thousand infant skulls were exposed to view. A story which may be fact or fiction. But while fully admitting the probability of invention and exaggeration in the relations of enemies, and the fact that undue prejudice is likely to somewhat exaggerate the probable evils of the mysterious and unknown, how could it be otherwise than that during fourteen centuries many crimes should have been committed in those silent and safe retreats? Nor, indeed, is experience opposed to the possibility of the highest fervour of an unnatural enthusiasm being compatible with more human passions. The virgin who,

' Ut flos in septis secretus nascitur hortis Ignotus pecori,'

as eulogised by the virgin-chorus in the beautiful epithalamium of $\mathrm{Ca}$ tullus, might be recognised in the youthful 'religieuse' if only human passion could be excluded; but the story of Heloise and Abelard is not a solitary proof of the superiority of human nature over an impossible and artificial spirituality. 
stigation of their director, a priest called David, the nuns, it is reported, were seized with an irresistible desire of imitating the primitive Adamite simplicity : the novices were compelled to return to the simple nudity of the days of innocence when taking exercise in the conventual gardens, and even at their devotions in the chapel. The novice Madeleine, on one occasion, was reprimanded for concealing her bosom with the altar-cloth at communion. She was originally of a pure and artless mind; and only gradually and stealthily she was corrupted by the pious arguments of her priest. This man, Picart by name-one of that extensive class the 'tristes obscœni,' of whom the Angelos and Tartuffes* are representatives-succeeded to the vacant office of directing confessor to the nuns of Louviers; and at once embraced the opportunities of the confessional. Without repeating all the disgusting scenes that followed, as given by Michelet, it is only necessary to add that the miserable nun became the mistress and helpless creature of her seducer. 'He employed her as a magical charm to gain over the rest of the nuns. A holy wafer steeped in Madeleine's blood and buried in the garden would be sure to disturb their senses

* As Tartuffe privately confesses,

'L'amour qui nous attache aux beautés éternelles

N'étouffe pas en nous l'amour des temporelles.

Pour être dérot, je n'en suis pas moins homme.' 
and their minds. This was the very year in which Urban Grandier was burned. Throughout France men spoke of nothing but the devils of Loudun. . . Madeleine fancied herself bewitched and knocked about by devils; followed about by a lewd cat with eyes of fire. By degrees other nuns caught the disorder, which showed itself in odd supernatural jerks and writhings.'

The Superior was not averse to the publication of these events, having the example and reputation of Loudun before her. Little is new in the possession and exorcism: for the most part they are a repetition of those of Aix and Loudun. During a brief interval the devils were less outrageous: for the Cardinal-minister was meditating a reform of the monastic establishments. Upon his death they commenced again with equal violence. Picart was now dead-but not so the persecution of his victim. The priests recommenced miracle-working with renewed vigour.* Saved from immediate death by a fortunate

* To the diabolic visions of the other they opposed those of ' a certain Anne of the Nativity, a girl of sanguine hysterical temperament, frantic at need, and half mad-so far at least as to believe in her own lies. A kind of dog-fight was got up between the two. They besmeared each other with false charges. Anne saw the devil quite naked by Madeleine's side. Madeleine swore to seeing Anne at the Sabbath with the Lady Superior, the Mother Assistant, and the Mother of the novices. . . . Madeleine was condemned, without a hearing, to be disgraced, to have her body examined for the marks of the devil. They tore off her veil and gown, and made her the wretched sport of a vile curiosity that would have pierced till she 
or, as it may be deemed, unfortunate sensitiveness to bodily pain, she was condemned for the rest of her life to solitary confinement in a fearful dungeon, in the language of her judges to an in pace. There lying tortured, powerless in a loathsome cell, their prisoner was alternately coaxed and threatened into admitting all sorts of crimes, and implicating whom they wished.* The further cruelties to which the lust, and afterwards the malignancy, of her gaolers submitted her were not brought to an end by the interference of parliament in August 1647, when the destruction of the Louviers establishment was decreed.

The guilty escaped by securing, by intimidation, the

bled again in order to win the right of sending her to the stake. Leaving to no one else the care of a scrutiny which was in itself a torture, these virgins, acting as matrons, ascertained if she were with child or no; shaved all her body, and dug their needles into her quivering flesh to find out the insensible spots.'-La Sorcière.

* The horrified reader may see the fuller details of this case in Michelet's La Sorcière, who takes occasion to state that, than 'The History of Madeleine Bavent, a nun of Louriers, with her examination, \&c., 1652, Rouen,' he knows of 'no book more important, more dreadful, or worthier of being reprinted. It is the most powerful narrative of its class. Piety Afficted, by the Capuchin Esprit de Bosrager, is a work immortal in the annals of tomfoolery. The two excellent pamphlets by the doughty surgeon Yvelin, the Inquiry and the Apology, are in the Library of Ste. Geneviève.'-La Sorcière, the Witch of the Middle Ages, chap. riii. Whatever exaggeration there may possibly be in any of the details of these and similar histories, there is not any reasonable doubt of their general truth. It is much to be wished, indeed, that writers should, in these cases, always confine themselves to the simple facts, which need not any imaginary or fictitious additions. 
silence of their prisoner, who remained a living corpse in the dungeons of the episcopal palace of Rouen. The bones of Picart were exhumed, and publicly burned; the curé Boullé, an accomplice, was dragged on a hurdle to the fish-market, and there burned at the stake. So terminated this last of the trilogical series. But the hysterical or demoniacal disease was. as furious as ever in Germany in the middle of the eighteenth century; and was attended with as tremendous effects at Würzburg as at Louviers.

In Germany during the seventeenth century witches felt the fury of both Catholic and Protestant zeal: but in the previous age prosecutions are directed against Protestant witches. They abounded in Upper Germany in the time of Innocent VIII., and what numbers were executed has been already seen. When the revolutionary party had acquired greater strength and its power was established, they vied with the conservatives in their vigorous attacks upon the empire of Satan.

Luther had been sensible to the contagious fear that the great spiritual enemy was actually fighting in the ranks of his enemies. He had personal experience of his hostility. Immured for his safety in a voluntary but gloomy prison, occupied intensely in the plan of a mighty revolution against the most powerful hierarchy that has ever existed, engaged continuously in the laborious task of translating the 
Sacred Scriptures, only partially freed from the prejudices of education, it is little surprising that the antagonist of the Church should have experienced infernal hallucinations. This weakness of the champion of Protestantism is at least more excusable than the pedantic folly of the head of the English Church. When Luther, however, could seriously affirm that witchcraft 'is the devil's proper work wherewith, when God permits, he not only hurts people but makes away with them; for in this world we are as guests and strangers, body and soul, cast under the devil : that idiots, the lame, the blind, the dumb are men in whom ignorant devils have established themselves, and all the physicians who attempt to heal these infirmities as though they proceeded from natural causes, are ignorant blockheads who know nothing about the power of the demon,' we cannot be indignant at the blind credulity of the masses of the people. It appears inconsistent that Luther, averse generally to supernaturalism, should yet find no difficulty in entertaining these irrational diabolistic ideas. The circumstances of his life and times sufficiently explain the inconsistency.*

* The following sentence in his recorded conversation, when the free thoughts of the Reformer were unrestrained in the presence of his most intimate friends, is suggestive. ' I know,' says he, 'the devil thoroughly well; he has over and over pressed me so close that I scarcely knew whether I was alive or dead. Sometimes he has thrown me into such despair that $I$ eren knew not that there is a 
On the eve of the prolonged and ferocious struggle on the continent between Catholicism and Protestantism a wholesale slanghter of witches and wizards was effected, a fitting prologue to the religious barbarities of the Thirty Years' War. Fires were kindled almost simultaneously in two different places, at Bamburg and Würzburg; and seldom, even in the annals of witchcraft, have they burned more tremendously. The prince-bishops of those territories had long . been anxious to extirpate Lutheranism from their dioceses. Frederick Forner, Suffragan of Bamburg, a vigorous supporter of the Jesuits, was the chief agent of John George II. He waged war upon the heretical sorcerers in the 'whole armour of God,' Panoplia armaturce Dei. According to the statements of credible historians, nine hundred trials took

God, and had great doubts about our dear Lord Christ. But the Word of God has speedily restored me' (Luther's Tischreden or Table Talk, as eited in Howitt's History of the Supernatural). The eloquent controversialist Bossuet and the Catholics have been careful to avail themselves of the impetuosity and incautiousness of the great German Reformer.

Of all the leaders of the religious revolution of the sixteenth century, the Reformer of Zurich was probably the most liberally inclined; and Zuinglius' unusual charity towards those ancient sages and others who were ignorant of Christianity, which induced him to place the names of Aristides, Socrates, the Gracchi, \&c., in the same list with those of Moses, Isaiah, and St. Paul, who should meet in the assembly of the virtuous and just in the future life, obliged Luther openly to profess of his friend that 'he despaired of his salvation,' and has provoked the indignation of the bishop of Meaux.Variations des Eglises Protestantes, ii. 19 and 20. 
place in the trro courts of Bamburg and Zeil between 1625 and 1630. Six hundred were burned by Bishop George II. No one was spared. The chancellor, his son, Dr. Horn, with his wife and daughters, many of the lords and councillors of the bishop's court, women and priests, suffered. After tortures of the most extravagant kind it was extorted that some twelve hundred of them were confederated to bewitch the entire land to the extent that 'there would have been neither wine nor corn in the country, and that thereby man and beast would have perished with hunger, and men would be driven to

- eat one another. There were even some Catholic priests among them who had been led into practices too dreadful to be described, and they confessed among other things that they had baptized many children in the devil's name. It must be stated that these confessions were made under tortures of the most fearful kind, far more so than anything that was practised in France or other countries.

The number brought to trial in these terrible proceedings were so great, and they were treated with so little consideration, that it was usual not even to take the trouble of setting down their names; but they were cited as the accused Nos. 1, 2, 3, \&c. The Jesuits took their confessions in private, and they 4. made up the lists of those who were understood to have been denounced by them.' 
More destructive still were the burnings of Würzburg at the same period under the superintendence of Philip Adolph, who ascended the episcopal throne in 1623. In spite of the energy of his predecessors, a grand confederacy of sorcerers had been discovered, and were at once denounced.*

Nine appears to have been the greatest number, and sometimes only two were sent to execution at once. Five are specially recorded as having been

* 'A catalogue of nine and twenty brände or burnings during a very short period of time, previous to the February of 1629 , will give the best notion of the horrible character of these proceedings; it is printed,' adds Mr. Wright, 'from the original records in Hauber's Bibliotheca Magica.' E.g. in the Fifth Brände are enumerated: (1) Latz, an eminent shopkeeper. (2) Rutscher, a shopkeeper. (3) The housekeeper of the Dean of the cathedral. (4) The old wife of the Court ropemaker. (5) Jos. Sternbach's housekeeper. (6) The wife of Baunach, a Senator. (7) A woman named Znickel Babel. (8) An old woman. In the Sixteenth Burning: (1) A noble page of Ratzenstein. (2) A boy of ten years of age. $(3,4,5)$ The two daughters of the Steward of the Senate and his maid. (6) The fat ropemaker's wife. In the Twentieth Burning : (1) Gobel's child, the most beautiful girl in Würzburg. (2) A student on the fifth form, who knew many languages, and was an excellent musician. $(3,4)$ Two boys from the New Minster, each twelve years old. (5) Stepper's little daughter. (6) The woman who kept the bridge gate. In the Twentysixth Burning are specified: (1) David Hans, a Canon in the New Minster. (2) Weydenbusch, a Senator. (3) The innkeeper's wife of the Baumgarten. (4) An old woman. (5) The little daughter of Valkenberger was privately executed and burned on her bier. (6) The little son of the town pouncil bailiff. (7) Herr Wagner, vicar in the cathedral, was burned alive.-Narratives of Sorcery and Magic. The facts are taken from Dr. Soldan's Geschichte der Hexenprocesse, whose materials are to be found in Horst's Zauber Bibliothek and Hauber's Bibliotheca Magica. 
burned alive. The victims are of all professions and trades - vicars, canons, goldsmiths, butchers, \&c. Besides the twenty-nine conflagrations recorded, many others were lighted about the same time: the names of whose prey are not written in the Book of Death. Frederick Spee, a Jesuit, formerly a violent enemy of the witches, but who had himself been incriminated by their extorted confessions at these holocausts, was converted to the opposite side, and wrote the 'Cautio Criminalis,' in which the necessity of caution in receiving evidence is insisted upon-a caution, without doubt, 'very necessary at that time for the magistracy throughout Germany?' All over Germany executions, if not everywhere so indiscriminately destructive as those in Franconia and at Würzburg, were incessant: and it is hardly the language of hyperbole to say that no province, no city, no village was without its condemned. 


\section{CHAPTER VII.}

Scotland one of the most Superstitious Countries in EuropeScott's Relation of the Barbarities perpetrated in the Witch-trials under the auspices of James VI.-The Fate of Agnes Sampson, Euphane MacCalzean, \&c.-Irrational Conduct of the Courts of Justice-Causes of voluntary Witch-confessions-Testimony of Sir G. Mackenzie, \&c.-Trial and Execution of Margaret Barelay-Computation of the number of Witches who suffered death in England and Scotland in the sixteenth and seventeenth centuries-Witches burned alive at Edinburgh in 1608-The Lancashire Witches-Sir Thomas Overbury and Dr. FormanMargaret Flower and Lord Rosse.

Scotland, by the physical features of the country and by the character and habits of the people, is eminently apt for the reception of the magical and supernatural of any kind ; * and during the century from 1563 it was almost entirely subject to the dominion of Satan. Sir Walter Scott has narrated some of the most prominent cases and trials in the northern part of the island. The series may be said

* A late philosophic writer has ventured to institute a comparison in point of superstition and religious intolerance between Spain and Scotland. The latter country, however, has denied to political what it conceded to priestly government: hence its superior material progress and prosperity.-Buckle's History of Civilisation in England. 
to commence from the confederated conspiracy of hell to prevent the union of James VI. with the Princess Anne of Denmark. An overwhelming tempest at sea during the voyage of these anti-papal, anti-diabolic royal personages was the appointed means of their destruction.

The human agents were Agnes Sampson, the wise wife of Keith (one of the better sort, who cured diseases, \&sc.); Dame Euphane MacCalzean, widow of a senator of the College of Justice, and a Catholic; Dr. John Fian or Cunninghame, a man of some learning, and of much skill in poison as well as in magic; Barbara Napier or Douglas; Geillis Duncan; with about thirty other women of the lowest condition. - When the monarch of Scotland sprung this strong covey of his favourite game, they afforded the Privy Council and himself sport for the greatest part of the remaining winter. He attended on the examinations himself. . . Agnes Sampson, after being an hour tortured by the twisting of a cord around her head according to the custom of the buccaneers, confessed that she had consulted with one Richard Grahame concerning the probable length of the king's life and the means of shortening it. But Satan, to whom at length they resorted for advice, told them in French respecting King James, Il est un homme de Dieu. The poor woman also acknowledged that she had held a meeting with those of her sisterhood, 
who had charmed a cat by certain spells, having four joints of men knit to its feet, which they threw into the sea to excite a tempest: they embarked in sieves with much mirth and jollity, the fiend rolling himself before them upon the waves dimly seen, and resembling a huge haystack in size and appearance. They went on board of a foreign ship richly laden with wines, where, invisible to the crew, they feasted till the sport grew tiresome; and then Satan sunk the vessel and all on board. Fian or Cunninghame was also visited by the sharpest tortures, ordinary and extraordinary. The nails were torn from his fingers with smiths' pincers; pins were driven into the places which the nails usually defended; his knees were crushed in the boots; his finger-bones were splintered in the pilniewincks. At length his constancy, hitherto sustained, as the bystanders supposed, by the help of the devil, was fairly overcome; and he gave an account of a great witch-meeting at North Berwick, where they paced round the church withershins-i.e. in reverse of the motion of the sun. Fian then blew into the lock of the church door, whereupon the bolts gave way: the unhallowed crew entered, and their master the devil appeared to his servants in the shape of a black man occupying. the pulpit. He was saluted with a "Hail, Master!" but the company were dissatisfied with his not having brought a picture of the king, repeatedly promised, 
which was to place his Majesty at the mercy of this infernal crew. . . . The devil, on this memorable occasion, forgot himself, and called Fian by his own name instead of the demoniacal sobriquet of Rob the Rowan, which had been assigned to him as Master of the Rows or Rolls. This was considered as bad taste; and the rule is still observed at every rendezvous of forgers, smugglers, or the like, where it is accounted very indifferent manners to name an individual by his own name in case of affording ground of evidence which may upon a day of trial be brought against him. Satan, something disconcerted, concluded the evening with a divertissement and a dance after his own manner. The former consisted in disinterring a new-buried corpse, and dividing it in fragments among the company ; and the ball was maintained by well-nigh two hundred persons, who danced a ring dance. . . . Dr. Fian, muffled, led the ring, and was highly honoured, generally acting as clerk or recorder. King James was deeply interested in those mysterious meetings, and took great delight to be present at the examinations of the accused. He sent for Geillis Duncan, and caused her to play before him the same tune to which Satan and his companions led the brawl in North Berwick churchyard. His ears were gratified in another way : for at this meeting it was said the witches demanded of the devil why he did bear such enmity against the 
king, who returned the flattering answer, that the king was the greatest enemy whom he had in the world. Almost all these poor wretches were executed: nor did Euphane MacCalzean's station in life save her from the common doom, which was strangling to death and burning to ashes thereafter. The majority of the jury which tried Barbara Napier, having acquitted her of attendance at the North Berwick meeting, were themselves threatened with a trial for wilful error upon an assize, and could only escape from severe censure and punishment by pleading guilty, and submitting themselves to the king's pleasure. The alterations and trenching,' adds Scott, 'which lately took place on the Castle-hill at Edinburgh for the purpose of forming the new approach to the city from the west, displayed the ashes of the numbers who had perished in this manner, of whom a large proportion must have been executed between 1590 - when the great discovery was made concerning Euphane MacCalzean and the wise wife of Keith and their accomplices-and the union of the crowns.' *

Euphane's exceptional doom was ' to be bound to the stake, and burned in ashes quick to the death.' 'Burning quick' was not an uncommon sentence: if the less cruel one of hanging or strangling first and afterwards burning was more usual. Thirty warlocks

* Sir W. Scott's Letters on Demonology and Witchcraft, ix. 
and witches was the total number executed on June 25th, 1591. A few, like Dr. Cunninghame, may have been really experienced in the use of poison and poisonous drugs. The art of poisoning has been practised perhaps almost as extensively as (often coextensively with) that of sorcery; a tremendous and mostly inscrutable crime which science, in all ages, has been able more surely to conceal than to detect.

Two facts eminently illustrate the barbarous iniquity of the Courts of Justice when dealing with their witch prisoners. An expressed malediction, or frequently an almost inaudible mutter, followed by the coincident fulfilment of the imprecation, was accepted eagerly by the judges as sufficient proof (an antecedent one, contrary to the boasted principle of English law at least, which assumes the innocence until the guilt has been proved, of the accused) of the crime of the person arraigned. And they complacently attributed to conscious guilt the ravings produced by an excruciating torture-that equally inhuman and irrational invention of judicial cruelty; confidently boasting that they were careful to sentence no person without previous confession duly made.

But these confessions not seldom were partly extracted from a natural wish to be freed from the persecution of neighbours as well as from present bodily torture. Sir George Mackenzie, Lord Advocate 
of Scotland during the period of the greatest fury, and himself president at many of the trials, a believer, among other cases in his Criminal Law, 1678, relates that of a condemned witch who had confessed judicially to him and afterwards 'told me under secrecy, that she had not confessed because she was guilty; but being a poor creature who wrought for her meat, and being defamed for a witch she knew she should starve, for no person thereafter would either give her meat or lodging, and that all men would beat her and set dogs at her, and that therefore she desired to be out of the world. Whereupon she wept most bitterly, and upon her knees called God to witness to what she said. Another told me that she was afraid the devil would challenge a right to her after she was said to be his servant, and would haunt her, as the minister said when he was desiring her to confess, and therefore she desired to die. And really,' admits the learned judge, ' ministers are ofttimes indiscreet in their zeal to have poor creatures to confess in this; and I recommend to judges that the wisest ministers should be sent to them; and that those who are sent should be cautious in this particular.' Another confession at the supreme moment of the same sort, as recorded by the Rev. G. Sinclair in 'Satan's Invisible World Discovered' is equally significant and genuine. What impression it left upon the pious clergyman will be seen in his 
concluding inference. The witch, ' being carried forth to the place of execution, remained silent during the first, second, and third prayer, and then, perceiving there remained no more but to rise up and go to the stake, she lifted up her body and with a loud voice cried out, "Now all you that see me this day know that I am now to die as a witch by my own confession, and I free all men, especially the ministers and magistrates, of the guilt of my blood. I take it wholly upon myself-my blood be upon my own head; and as I must make answer to the God of heaven presently, I declare I am as free of witchcraft as any child. But being delated by a malicious woman, and put in prison under the name of a witch; disowned by my husband and friends, and seeing no ground of hope of my coming out of prison or ever coming in credit again, through the temptation of the devil I made up that confession on purpose to destroy my own life, being weary of it, and choosing rather to die than live"- and so died; which lamentable story as it did then astonish all the spectators, none of which could restrain themselves from tears, so it may be to all a demonstration of Satan's subtlety, whose design is still to destroy all, partly by tempting many to presumption, and some others to despair.'

The trial of Margaret Barclay took place in 1613. Her crime consisted in having caused by means of spells the loss of a ship at sea. She was said to 
have had a quarrel with the owner of the shipwrecked vessel, in the course of which she uttered a wish that all on board might sink to the bottom of the sea. Her imprecation was accomplished, and upon the testimony of an itinerant juggler, John Stewart, she was arraigned before a Court of Justice.' With the help of the devil in the shape of a handsome black dog, she had moulded some figures of clay representing the doomed sailors, which with the prescribed rites were thrown into the deep. We are informed by the reporters of the proceedings at this examination, that 'after using this kind of gentle torture [viz. placing the legs in a pair of stocks and laying on gradually increasing weights of iron bars], the said Margaret began, according to the increase of the pain, to cry and crave for God's cause to take off her shin the foresaid irons, and she should declare truly the whole matter. Which being removed, she began at her formal denial; and being of new assayed in torture as before, she then uttered these words: "Take off, take off! and before God I shall show you the whole form." And the said irons being of new, upon her faithful promise, removed, she then desired my Lord of Eglinton, the said four justices, and the said Mr. David Dickson, minister of the burgh; Mr. George Dunbar, minister of Ayr; Mr. Mitchell Wallace, minister of Kilmarnock; Mr. John Cunninghame, minister of Dalry; and Hugh Kennedy, provost 
of Ayr, to come by themselves and to remove all others, and she should declare truly, as she should answer to God, the whole matter. Whose desire in that being fulfilled, she made her confession in this manner without any kind of demand, freely without interrogation: God's name by earnest prayer being called upon for opening of her lips and easing of her heart, that she by rendering of the truth might glorify and magnify His holy name and disappoint the enemy of her salvation.'

One of those involved in the voluntary confession was Isabel Crawford, who was frightened into admitting the offences alleged. In court, when asked if she wished to be defended by counsel, Margaret Barelay, whose hopes and fears were revived at seeing her husband, answered, 'As you please; but all I have confessed was in agony of torture; and, before. God, all I have spoken is false and untrue.' She was found guilty; sentenced to be strangled at the stake; her body to be burned to ashes. Isabel Crawford, after a short interval, was subjected to the same sort of examination: a new commission having been granted for the prosecution, and ' after the assistantminister of Irvine, Mr. David Dickson, had made earnest prayers to God for opening her obdurate and closed heart, she was subjected to the torture of iron bars laid upon her bare shins, her feet being in the stocks. She endured this torture with incredible 
firmness, since she did "admirably, without any kind of din or exclamation, suffer above thirty stone of iron to be laid on her legs, never shrinking thereat in any sort, but remaining, as it were, steady." But in shifting the situation of the iron bars, and removing them to another part of her shins, her constancy gave way; she broke out into horrible cries of "Take off! take off!" On being relieved from the torture she made the usual confession of all that she was charged with, and of a connection with the devil which had subsisted for several years. Sentence was given against her accordingly. After this had been denounced she openly denied all her former confessions, and died without any sign of repentance; offering repeated interruptions to the minister in his prayers, and absolutely refusing to pardon the executioner.' * It might be possible to form an imperfect estimate of how many thousands were sacrificed in the Jacobian persecution in Scotland alone from existing historical records, which would express, however, but a small proportion of the actual number: and parish registers may still attest the quantity of fuel provided at a considerable expense, and the

\section{* Letters on Demonology and Witchcraft, ix.}

The Scotch trials and tortures, of which the above cases are but one or two out of a hundred similar ones, are perhaps the more extraordinary as being the result of mere superstition: religious or political heresy being seldom an excuse for the punishment and an aggravation of the offence. 
number of the fires. By a moderate computation an average number of two hundred annually, making. a total of eight thousand, are reckoned to have been burned in the last forty years of the sixteenth cen-: tury.*

In England, from 1603 to 1680, seventy thousand persons are said to have been executed; and during the fifteen hundred years elapsed since the triumph of the Christian religion, millions are reckoned to have been sacrificed on the bloody altars of the Christian Moloch. An entry in the minutes of the proceedings in the Privy Council for 1608 reveals that even James's ministers began to experience some horror of the consequences of their instructions. And the following free testimony of one of them is truly 'an appalling record: ' - '1608.-December 1.The Earl of Mar declared to the council that some women were taken in Broughton [suburban Edinburgh] as witches, and being put to an assize and convicted, albeit they persevered constant in their denial to the end, yet they were burned quick after such a cruel manner that some of them died in

* A larger proportion of victims than even those of the Holy Office during an equal space of time. According to Llorente (Hist. de l'Inquisition) from 1680 to 1781 , the latter period of its despotism (which flourished especially under Charles II., himself, as he was convinced, a victim of witch-malice), between 13,000 and 14,000 persons suffered by various punishments: of which number, however, 1,578 were burned alive. 
despair, renouncing and blaspheming God; and others half-burned broke out of the fire, and were cast quick in it again till they were burned to the death."*

Equally monstrous and degrading were the disclosures in the torture-chambers; and many admitted that they had had children by the devil. The circumstances of the Sabbath, the various rites of the compact, the forms and method of bewitching, the manner of sexual intercourse with the demons-these were the principal staple of the judicial examinations.

In the southern part of the island witch-hanging or burning proceeded with only less vehemence than in Scotland. One of the most celebrated cases in the earlier half of the seventeenth century (upon which Thomas Shadwell the poet laureate, who, under the name of MacFlecknoe, is immortalised by the satire of Dryden, founded a play) is the story of the Lancashire Witches. This persecution raged at two separate periods; first in 1613, when nineteen prisoners were brought before Sir James Altham and Sir Edward Bromley, Barons of Exchequer. Elizabeth Southern, known as 'Mother Demdike' in the poet laureate's drama, is the leader of the criminals. In 1634 the proceedings were renewed wholly on the evidence of a boy who, it was after-

* The terrestrial and real Fiends seem to hare striven to realise on earth and to emulate the 'Tartarus horrificos eructans faucibus æstus' described by the Epicurean philosophic poet (Lucretius, De Rerum Naturâ, iii.). 
wards ascertained, had been instructed in his part against an old woman named Mother Dickenson. The evidence was of the feeblest sort; nor are its monotonous details worth repetition. Out of some forty persons implicated on both occasions, fortunately the greater number escaped. 'Lancashire Witches,' a term so hateful in its origin, has been long transferred to celebrate the superior charms (of another kind) of the ladies of Lancashire; and the witches' spells are those of natural youth and beauty.

The social position of Sir Thomas Overbury has made his fate notorious. An infamous plot had been invented by the Earl of Rochester (Robert Kerr) and the Countess of Essex to destroy a troublesome obstacle to their contemplated marriage. The practice of 'hellish charms' is only incidental; an episode in the dark mystery. Overbury was too well acquainted with royal secrets (whose disgusting and unnatural kind has been probably correctly conjectured), too important for the keeping of even a private secretary. His ruin was determined by the revenge of the noble lovers and sealed by the fear of the king. At the end of six months he had been gradually destroyed by secret poison in his prison in the Tower (to which for an alleged offence he had been committed) by the agency of Dr. Forman, a famous 'pharmaceutic,' under the auspices of the 
Earl of Rochester. This Dr. Forman had been previously employed by Lady Essex, a notorious dame d'honneur at James's Court, to bewitch the Earl to an irresistible love for her, an enchantment which required, apparently, no superhuman inducement. A Mrs. Turner, the countess's agent, was associated. with this skilful conjuror. They were instructed also to bewitch Lord Essex, lately returned from abroad, in the opposite way-to divert his love from his wife.*

* The husband was impracticable; he could not be disenchanted. Conjurations and charms failing, 'the countess was instructed to bring against the Earl of Essex a charge of conjugal incapacity: A commission of reverend prelates of the church was appointed to sit in judgment, over whom the king presided in person; and a jury of matrons was found to give their opinion that the Lady Essex was a maiden.' Divorce was accordingly pronounced, and with all possible haste the king married his favourite to the appellant with great pomp at Court. After the conspirators had been arraigned by the public indignation, a curious incident of the trial, according to a cotemporary report, was, that there being 'showed in court certain pictures of a man and a woman made in lead, and also a mould of brass wherein they were cast; a black scarf also full of white crosses which Mrs. Turner had in her custody; enchanted paps and other pictures [as well as a list of some of the devil's particular names used in conjuration], suddenly was heard a crack from the scaffold, which carried a great fear, tumult, and commotion amongst the spectators and through the hall; every one fearing hurt as if the devil had been present and grown angry to have his workmanship known by such as were not his own scholars' (Narratives of Sorcery and Magic, by Thomas Wright). Whatever may have been the crime or crimes for the knowledge of which Sir Thomas Overbury was doomed, it is significant that for his own safety the king was compelled to break an oath (sworn upon his knees before the judges he had purposely sumnoned, with an imprecation that God's curse might light upon him 
Two women were executed at Lincoln, in 1618, for bewitching Lord Rosse, eldest son of the Earl of Rutland, and others of the family-Lord Rosse being bewitched to death; also for preventing by diabolic arts the parents from having any more children. Before the Lord Chief Justice of the Common Pleas and one of the Barons of the Exchequer, it was proved that the witches had effected the death of the noble lord by burying his glove in the ground, and 'as that glove did rot and waste, so did the liver of the said lord rot and waste.' Margaret Flower confessed she had 'two familiar spirits sucking on her, the one white, the other black spotted. The white sucked under her left breast,' \&c.

and his posterity for ever if he failed to bring the guilty to deserved punishment), and to not only pardon but remunerate his former favourite after he had been solemnly convicted and condemned to a felon's death. The crime, the knowledge of which prevented the appearance of Somerset at the gibbet or the scaffold, has been supposed by some, with scarcely sufficient cause or at least proof, to be the murder by the king of his son Prince Henry. Doubt has been strongly expressed of the implication at all of the farourite in the death of Orerbury: the evidence produced at the trial about the poisoning being, it seems, made up to conceal or to mystify the real facts. 


\section{CHAPTER VIII.}

The Literature of Europe in the Seventeenth Century proves the Universality and Horror of Witcheraft-The most acute and most liberal Men of Learning convinced of its Reality-Erasmus and Francis Bacon-Lawyers prejudiced by Legislation-Matthew Hale's judicial Assertion-Sir Thomas Browne's TestimonyJohn Selden-The English Church least Ferocious of the Protestant Sects-Jewell and Hooker-Independent ToleranceWitcheraft under the Presbyterian Government-Matthew Hopkins-Gaule's 'Select Cases of Conscience'-Judicial and Popular Methods of Witch-discovery-Preventive CharmsWitchfinders a legal and numerous Class in England and Scotland-Remission in the Severity of the Persecution under the Protectorship.

HAD we not the practical proof of the prevalence of the credit of the black art in accomplished facts, the literature of the first half of the seventeenth century would be sufficient testimony to its horrid dominion. The works of the great dramatists, the writings of men of every class, continually suppose the universal power and horror of witchcraft. Internal evidence is abundant. The witches of Macbeth are no fanciful creation, and Shakspeare's representation of La Pucelle's fate is nothing more than a copy from life. 
What the vulgar superstition must have been may be easily conceived when men of the greatest genius or learning credited the possibility, and not only a theoretical but actual occurrence, of these infernal phenomena. Gibbon is at a loss to account for the fact that the acute understanding of the learned Erasmus, who could see through much more plausible fables, believed firmly in witchcraft.* Francis Bacon, the advocate and second founder of the inductive method and first apostle of the Utilitarian philosophy, opposed though he might have been to the vulgar persecution, was not able to get rid of the principles upon which the creed was based. $\dagger$ Sir Edward Coke, his contemporary, the most acute lawyer of the age, or (as it is said) of any time, ventured even to define the devil's agents in witchcraft. Sir Thomas Browne (author of 'Pseudodoxia Epidemica' or 'Vulgar Errors!'), a physician and writer of considerable merit, and Sir Matthew Hale, in 1664, proved their faith, the one

* See Miscellaneous Works : Abstract of my Readings.

$\dagger$ 'Consorting with them [the unclean spirits who have fallen from their first estate] and all use of their assistance is unlawful; much more any worship or veneration whatsoever. But a contemplation and knowledge of their nature, power, illusions, not only from passages of sacred seripture but from reason or experience, is not the least part of spiritual wisdom. So truly the Apostle, "We are not ignorant of his wiles." And it is not less permissible in theology to investigate the nature of demons, than in physics to investigate the nature of drugs, or in ethics the nature of rice.'-De Augmentis Scientiarum, lib. iii. 2. 
by his solemn testimony in open court, the other by his still more solemn sentence.

If theologians were armed by the authority or their interpretation of Scripture, lawyers were no less so by that of the Statute Book. Judge Hale, in an address to the jury at Bury St. Edmund's, carefully weighing evidence, and, summing up, assures them he did 'not in the least doubt there are witches: first, because the Scriptures affirmed it; secondly, because the wisdom of all nations, particularly of our own, had provided laws against witchcraft which

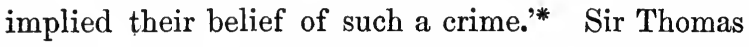
Browne, who gave his professional experience at this trial, to the effect that the devil often acts upon human bodies by natural means, afflicting them in a more surprising manner through the diseases to which they are usually subject; and that in the particular case, the fits (of vomiting nails, needles, deposed by

* Unfortunately for the cause of truth and right, Sir Matthew Hale's reasons are not an exceptional illustration of the mischief according to Roger Bacon's experience of 'three very bad arguments we are always using-This has been shown to be so; This is customary ; This is universal: Therefore it must be kept to.' Sir Thomas Browne, unable, as a man of science, to accept in erery particular alleged the actual bonâ fide reality of the devil's power, makes a compromise, and has 'recourse to a fraud of Satan,' explaining that he is in reality but a clever juggler, a transcendent physician who knows how to accomplish what is in relation to us a prodigy, in knowing how to use natural forces which our knowledge has not yet discovered. Such an unworthy compromise was certainly not fitted to arouse men from their 'cauchemar démonologique.'-See Révue des Deux Mondes, Aug. 1, 1858. 
other witnesses) might be natural, only raised to a great degree by the subtlety of the devil cooperating with the malice of the witches, employs a wellknown argument when he declares ('Religio Medici'), ' Those that to confute their incredulity desire to see apparitions shall questionless never behold any. The devil hath these already in a heresy as capital as witchcraft; and to appear to them were but to convert them.'

John Selden, a learned lawyer, but of a liberal mind, was gifted with a large amount of common sense, and it might be juster to attribute the dictum which has been supposed to betray ' $a$ lurking belief' to an excess of legal, rather than to a defect of intellectual, perception. Selden, inferring that 'the law against witches does not prove there be any, but it punishes the malice of those people that use such means to take away men's lives,' proceeds to assert that ' if one should profess that by turning his hat thrice and crying "Buz," he could take away a man's life (though in truth he could do no such thing), yet this were a just law made by the state, that whosoever shall turn his hat . . . with an intention to take away a man's life, should be put to death. ${ }^{\prime *}$

* Table Talk or Discourses of John Selden. Although it must be excepted to the lawyer's summary mode of dealing with an imaginary offence, we prefer to give that eminent patriot at least the benefit of the doubt, as to his belief in witcheraft. 
If men of more liberal sentiments were thus enslaved to old prejudices, it is not surprising that the Church, not leading but following, should firmly maintain them. Fortunately for the witches, without the motives actuating in different ways Catholics and Calvinists, and placed midway between both parties, the reformed English Church was not so much interested in identifying her crimes with sorcerers as in maintaining the less tremendous formulæ of Divine right, Apostolical succession, and similar pretensions. Yet if they did not so furiously engage themselves in actual witch-prosecutions, Anglican divines have not been slow in expressly or impliedly affirming the reality of diabolical interposition. Nor can the most favourable criticism exonerate them from the reproach at least of having witnessed without protestation the barbarous cruelties practised in the name of heaven; and the eminent names of Bishop Jewell, the great apologist of the English Church, and of the author of the 'Ecclesiastical Polity,' among others less eminent, may be claimed by the advocates of witchcraft as respectable authorities in the Established Church. The 'judicious' Hooker affirms that the evil spirits are dispersed, some in the air, some on the earth, some in the waters, some among the minerals, in dens and caves that are under the earth, labouring to obstruct and, if possible, to destroy the works of God. They 
were the dii inferi [the old persuasion] of the heathen worshipped in oracles, in idols, \&c.* The privilege of ' casting out devils' was much cherished and long retained in the Established Church.

During the ascendency of the Presbyterian party from 1640 to the assumption of the Protectorship by Cromwell, witches and witch-trials increased more than ever; and they sensibly decreased only when the Independents obtained a superiority. The adherents of Cromwell, whatever may have been their own fanatical excesses, were at least exempt from the intolerant spirit which characterised alike their Anglican enemies and their old Presbyterian allies. The astute and vigorous intellect of the great revolutionary leader, the champion of the people in its struggles for civil and religious liberty, however much he might affect the forms of the prevailing religious sentiment, was too sagacious not to be able to penetrate, with the aid of the counsels of the author of the 'Treatise of Civil Power in Ecclesiastical Causes,' who so triumphantly upheld the fundamental principle of Protestantism, $\dagger$ somewhat

* Quoted in Howitt's History of the Supernatural. The author has collected a mass of evidence 'demonstrating an universal faith,' a curious collection of various superstition. He is indignant at the colder faith of the Anglican Church of later times.

† 'Seeing therefore,' infers Milton, the greatest of England's patriots as well as poets, "that no man, no synod, no session of men, though called the Church, can judge definitively the sense of 
beneath the surface. In what manner the Presbyterian Parliament issued commissions for inquiring into the crimes of sorcery, how zealously they were supported by the clergy and people, how Matthew Hopkins-immortal in the annals of English witchcraft-exercised his talents as witchfinder-general, are facts well known.*

That the strenuous antagonists of despotic dogmas, by whom the principles of English liberty were first inaugurated, that they should so fanatically abandon their reason to a monstrous idea, is additional proof

Scripture to another man's conscience, which is well known to be a maxim of the Protestant religion; it follows plainly, that he who holds in religion that belief or those opinions which to his conscience and utmost understanding appear with most evidence or probability in the Scripture, though to others he seem erroneous, can no more be justly censured for a heretic than his censurers, who do but the same thing themselves, while they censure him for so doing. - . . . To Protestants therefore, whose common rule and touchstone is the Scripture, nothing can with more conscience, more equity, nothing more Protestantly can be permitted than a free and lawful debate at all times by writing, conference, or disputation of what opinion soever disputable by Scripture. . . . How many persecutions, then, imprisonments, banishments, penalties, and stripes; how much bloodshed, have the forcers of conscience to answer for -and Protestants rather than Papists!' (A Treatise of Civil Power in Ecclesiastical Causes.) The reasons which induced Milton to exclude the Catholies of his day from the general toleration are more intelligible and more plausible, than those of fifty or sixty years since, when the Rev. Sidney Smith published the Letters of Peter Plymley.

* Displayed in the satire of Hudibras, particularly in Part II. canto 3, Part III. 1, and the notes of Zachary Grey. The author of this amusing political satire has exposed the foibles of the great Puritan party with all the rancour of a partisan. 
of the universality of superstitious prejudice. But the conviction, the result of a continual political religious persecution of their tenets, that if heaven was on their side Satan and the powers of darkness were still more inimical, cannot be fully understood unless by referring to those scenes of murder and torture. Hunted with relentless ferocity like wild beasts, holding conventicles and prayer meetings with the sword suspended over their heads, it is not surprising that at that period these English and Scotch Calvinists came to believe that they were the peculiar objects of diabolical as well as human malice. Their whole history during the first eighty years of the seventeenth century can alone explain this faith. Besides this genuine feeling, the clergy of the Presbyterian sect might be interested in maintaining a creed which must magnify their credit as miracle-workers.*

* The author of Hudibras, in the interview of the Knight and Sidrophel (William Lilly), enumerates the rarious practices and uses of astrology and witchcraft in vogue at this time, and employed by Court and Parliament with equal eagerness and emulation. Dr. Zachary Grey, the sympathetic editor of Hudibras, supplies much curious information on the subject in extracts from various old writers. 'The Parliament,' as he states, 'took a sure way to secure all prophecies, prodigies, and almanac-news from stars, \&c., in favour of their own side, by appointing a licenser thereof, and strictly forbidding and punishing all such as were not licensed. Their man for this purpose was the famous Booker, an astrologer, fortuneteller, almanac-maker, \&c. The words of his license in Rushorth are very remarkable-for mathematics, almanacs, and prognosti- 
The years 1644 and 1645 are distinguished as especially abounding in witches and witchfinders. In the former year, at Manningtree, a village in Essex, during an outbreak in which several women were tried and hanged, Matthew Hopkins first displayed his peculiar talent. Associated with him in his recognised legal profession was one John Sterne. They proceeded regularly on their circuit, making a fixed charge for their services upon each town or village. Swimming and searching for secret marks were the infallible methods of discovery. Hopkins, encouraged by an unexpected success, arrogantly assumed the title of 'Witchfinder-General.' His modest charges (as he has told us) were twenty shillings a town, which paid the expenses of travelling and living, and an additional twenty shillings a head cations. If we may believe Lilly, both he and Booker did conjure and prognosticate well for their friends the Parliament. He tells us, "When he applied for a license for his Merlinus Anglicus Junior (in Ap. 1644), Booker wondered at the book, made many impertinent obliterations, framed many objections, and swore it was not possible to distinguish between a king and a parliament; and at last licensed it according to his own fancy. Lilly delivered it to the printer, who, being an arch-Presbyterian, had five of the ministers to inspect it, who could make nothing of it, but said it might be printed; for in that he meddled not with their Dagon." (Lilly's Life.) Which opposition to Lilly's book arose from a jealousy that he was not then thoroughly in the Parliament's interest-which was true; for he frankly confesses, "that till the year 1645 he was more Cavalier than Roundhead, and so taken notice of ; but after that he engaged body and soul in the cause of the Parliament."' (Life.) Lilly was succeeded successively by his assistant Henry Coley, and John Partridge, the well-known object of Swift's satire.

a 2 
for every criminal brought to trial, or at least to execution.

The eastern counties of Huntingdon, Cambridge, Suffolk, Northampton, Bedford, were chiefly traversed; and some two or three hundred persons appear to have been sent to the gibbet or the stake by his active exertions. One of these specially remembered was the aged parson of a village near Framlingham, Mr. Lowes, who was hanged at Bury St. Edmund's. The pious Baxter, an eyewitness, thus commemorates the event: 'The hanging of a great number of witches in 1645 and 1646 is famously known. Mr. Calamy went along with the judges on the circuit to hear their confessions and see that there was no fraud or wrong done them. I spoke with many understanding, pious, learned, and credible persons that lived in the counties, and some that went to them in the prison and heard their sad confessions. Among the rest, an old reading parson named Lowes, not far from Framlingham, was one that was hanged, who confessed that he had two imps, and that one of them was always putting him upon doing mischief; and he being near the sea as he saw a ship under sail, it moved him to send it to sink the ship, and he consented and saw the ship sink before them.' Sterne, Hopkins's coadjutor, in an Apology published not long afterwards, asserts that Lowes had been indicted thirty years before for witchcraft; that he 
had made a covenant with the devil, sealing it with his blood, and had those familiars or spirits which sucked on the marks found on his body; that he had confessed that, besides the notable mischief of sinking the aforesaid vessel and making fourteen widows in one quarter of an hour, he had effected many other calamities; that far from repenting of his wickedness, he rejoiced in the power of his imps.

The excessive destruction and cruelty perpetrated by the indiscriminate procedure of the Witchfinder-General incited a Mr. Gaule, vicar of Great Staughton in Huntingdonshire, to urge some objections to the inhuman character of his method. Gaule, like John Cotta before him and others of that class, was provoked to challenge the propriety of the ordinary prosecutions, not so much from incredulity as from humanity, which revolted at the extravagance of the judges' cruelty. In 'Select Cases of Conscience touching Witches and Witchcraft,' the minister of Great Staughton describes from personal knowledge one of the ordinary ways of detecting the guilt of the accused. 'Having taken the suspected witch, she is placed in the middle of a room upon a stool or table, cross-legged, or in some other uneasy position, to which, if she submits not, she is then bound with cords: there is she watched and kept without meat or sleep for the space of four- 
and-twenty hours (for they say within that time they shall see her imps come and suck); a little hole is likewise made in the door for the imps to come in at, and, lest they should come in some less discernible shape, they that watch are taught to be ever and anon sweeping the room, and if they see any spiders or flies to kill them; and if they cannot kill them, then they may be sure they are her imps.'

'Swimming' and 'pricking' were the approved modes of discovery. By the former method the witch was stripped naked, securely bound (hands and feet being crossed), rolled up in a blanket or cloth, and carried to the nearest water, upon which she was laid on her back, with the alternative of floating or sinking. In case of the former event (the water not seldom refusing to receive the wretch, because-declares James I. - they had impiously thrown off the holy water of baptism) she was rescued for the fire or the gallows; while, in case of sinking to the bottom, she would be properly and clearly acquitted of the suspected guilt. Hopkins prided himself most on his ability for detecting special marks. Causing the suspected woman to be stripped naked or as far as the waist (as the case might be), sometimes in public, this stigmatic professor began to search for the hidden signs with unsparing scrutiny. Upon finding a mole or wart or any similar mark, they tried the 'insensibleness there- 
of' by inserting needles, pins, awls, or any sharppointed instrument; and in an old and withered crone it might not be difficult to find somewhere a more insensitive spot.

Such examinations were conducted with disregard equally for humanity and decency. All the disgusting circumstances must be sought for in the works of the writers upon the subject. Reginald Scot has collected many of the commonest. These marks were considered to be teats at which the demons or imps were used to be suckled. Many were the judicial and vulgar methods of detecting the guilty -by repeating the 'Lord's Prayer;' weighing against the church Bible; making them shed tears-for a witch ean shed tears only with the left eye, and that only with difficulty and in limited quantity. The counteracting or preventive charms are as numerous as curious, not a few being in repute in some parts at this day. 'Drawing blood' was most effective. Nailing up a horse-shoe is one of the best-known preventives. That efficacious counter-charm used to be suspended over the entrance of churches and houses, and no wizard or witch could brave it." 'Scoring

* Gay's witch complains :

'Straws, laid across, my pace retard.

The horse-shoe's nailed, each threshold's guard.

The stunted broom the wenches hide

For fear that I should up and ride.

They stick with pins my bleeding seat,

And bid me show my secret teat.' 
above the breath' is omnipotent in Scotland, where the witch was cut or 'scotched' on the face and forehead. Cutting off secretly a lock of the hair of the accused, burning the thatch of her roof and the thing bewitched; these are a few of the least offensive or obscene practices in counter-charming.* In what degree or kind the Fetish-charms of the African savages are more ridiculous or disgusting than those popular in England 200 years ago, it would not be easy to determine.

Matthew Hopkins pursued a lucrative trade in witch-hunting for some years with much applause and success. His indiscriminating accusations at last excited either the alarm or the indignation of his townspeople, if we may believe the tradition suggested in the well-known verses of Butler, who has no authority, apparently, for his insinuation ('Hudibras,' ii. 3), that this eminent Malleus did not die 'the common death of all men.' However it happened, his death is placed in the year 1647. An Apology shortly before had been published by him in refutation of an injurious report gaining ground that he

* The various love-charms, amulets, and spells in the pharmacy of witcheraft are (like the waxen image known, both to the ancient and modern art) equally monstrous and absurd. Of a more natural and

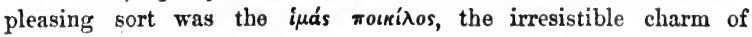
Aphrodite. Here-

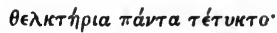

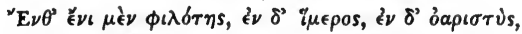

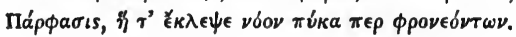


was himself intimately allied with the devil, from whom he had obtained a memorandum book in which were entered the names of all the witches in England. It is entitled 'The Discovery of Witches ; in Answer to several Queries lately delivered to the Judge of Assize for the County of Norfolk; and now published by Matthew Hopkins, Witchfinder, for the Benefit of the whole Kingdom. Printed for R. Royston, at the Angel in Inn Lane, 1647.'** It is, indeed, sufficiently probable that, confident of the increasing coolness, and perhaps of the wishes, of the magistrates, the mob, ever ready to wreak vengeance upon a disgraced favourite who has long abused the public patience, retaliated upon Hopkins a method of torture he had frequently inflicted upon others. $\dagger$

* Quoted by Sir W. Scott from a copy of this 'rery rare tract' in his possession.

+ Dr. Francis Hutchinson (Historical Essay), referring to the verses of Samuel Butler, says that he had often heard that some persons, 'out of indignation at the barbarity [of the witchfinder], took him and tied his own thumbs and toes, as he used to tie others; and when he was put into the water, he himself swam as they did.' But whether the usual fate upon that event awaited him does not appear. The verses in question are the following:-

' has not he, within a year,

Hang'd threescore of 'em in one shire,

Who after prov'd himself a witch,

And made a rod for his own breech?'

The Knight's Squire on the same occasion reminds his master of the more notorious of the deril's tricks of that and the last age:- 
Hopkins is the most famous of his class on account of his superior talent; but both in England and Scotland witchfinders, or prickers, as they were sometimes called, before and since his time aboundedof course most where the superstition raged fiercest. In Scotland they infested all parts of the country, practising their detestable but legal trade with entire impunity. The Scottish prickers enjoyed a great reputation for skill and success; and on a special occasion, about the time when Hopkins was practising in the South, the magistrates of Newcastle-uponTyne summoned from Scotland one of great professional experience to visit that town, then overrun with witches. The magistrates agreed to pay him all travelling expenses, and twenty shillings for every convicted criminal. A bellman was sent round the town to invite all complainants to prefer their

'Did not the deril appear to Martin

Luther in Germany for certain, And wonld have gull'd him with a trick

But Mart was too, too politic?

Did he not help the Dutch to purge

At Antwerp their cathedral church?

Sing catches to the saints at Mascon, And tell them all they came to ask him?

Appear in divers shapes to Kelly, And speak i' th' nun of Loudun's belly?

Meet with the Parliament's committee

At Woodstock on a pers'nal treaty?

\&c. \&c.'

Hudibras, II. 3. 
charges. Some thirty women, having been brought to the town-hall, were publicly subjected to an examination. By the ordinary process, twenty-seven on this single occasion were ascertained to be guilty, of whom, at the ensuing assizes, fourteen women and one man were convicted by the jury and executed.

Three thousand are said to have suffered for the crime in England under the supremacy of the Long Parliament. A respite followed on this bloody persecution when the Independents came into power, but it was renewed with almost as much violence upon the return of the Stuarts. The Protectorship had been fitly inaugurated by the rational protest of a gentleman, witness to the proceedings at one of the trials, Sir Robert Filmore, in a tract, 'An Advertizement to the Jurymen of England touching Witches.' This was followed two years later by a similar protest by one Thomas Ady, called, 'A Candle in the Dark; or, a Treatise concerning the Nature of Witches and Witchcraft: being Advice to Judges, Sheriffs, Justices of the Peace and Grand Jurymen, what to do before they pass Sentence on such as are arraigned for their Lives as Witches.' Notwithstanding the general toleration of the Commonwealth, in 1652, the year before Cromwell assumed the Dictatorship (1653-1658), there appeared to be a tendency to return to the old system, and several were executed in different parts of the country. Six were 
hanged at Maidstone. 'Some there were that wished rather they might be burned to ashes, alleging that it was a received opinion amongst many that the body of a witch being burned, her blood is thereby prevented from becoming hereafter hereditary to her progeny in the same evil, while by hanging it is not; but whether this opinion be erroneous or not,' the reporter adds, 'I am not to dispute.' 


\section{CHAPTER IX.}

Glanvil's Sadducismus Triumphatus - His Sentiments on Witchcraft and Demonology-Baxter's 'Certainty of the World of Spirits,' \&c.-Witch Trial at Bury St. Edmund's by Sir Matthew Hale, 1664-The Evidence adduced in Court-Two Witches hanged-Three hanged at Exeter in 1682-The last Witches judicially executed in England-Uniformity of the Evidence adduced at the Trials-Webster's Attack upon the Witch-Creed in 1677-Witch Trials in England at the end of the Seventeenth Century-French Parliaments vindicate the Diabolic Reality of the Crime-Witchcraft in Sweden.

THE bold licentiousness and ill-concealed scepticism of Charles II. and his Court, whose àespotic prejudices, however, supported by the zeal of the Church, prosecuted dissenters from a form of religion which maintained 'the right divine of kings to govern wrong,' might be indifferent to the prejudice of witchcraft. But the princes and despots of former times have seldom been more careful of the lives than they have been of the liberties, of their subjects. The formal apology for the reality of that crime published by Charles II.'s chaplain-in-ordinary, the Rev. Dr. Joseph Glanvil, against the modern Sadducees (a very inconsiderable sect) who denied both ghosts and witches, their well-attested 
apparitions and acts, has been already noticed. His philosophic inquiry (so he terms it) into the nature and operations of witcheraft (Sadducismus Triumphatus, Sadduceeism Vanquished, or 'Considerations about Witchcraft'), was occasioned by a case that came under the author's personal observation-the 'knockings' of the demon of Tedworth in the houseof a Mr. Mompesson. The Tedworth demon must have been of that sort of active spirits which has been so obliging of late in enlightening the spiritual séances of our time.

Glanvil traces the steps by which a well-meaning student may unwarily be involved in diablerie. This philosophical inquirer observes:-_'Those mystical students may, in their first address to the science [astrology], have no other design than the satisfaction of their curiosity to know remote and hidden things; yet that in the progress, being not satisfied within the bounds of their art, doth many times tempt the curious inquirer to use worse means of information; and no doubt those mischievous spirits, that are as vigilant as the beasts of prey, and watch all occasions to get us within their envious reach, are more constant attenders and careful spies upon the actions and inclinations of such whose genius and designs prepare them for their temptations. So that I look on judicial astrology as a fair introduction to sorcery and witchcraft; and who knows but it was first set 
on foot by the infernal hunters as a lure to draw the curiosos into those snares that lie hid beyond it. And yet I believe it may be innocently enough studied. . . . I believe there are very few among those who have been addicted to those strange arts of wonder and prediction, but have found themselves attacked by some unknown solicitors, and enticed by them to the more dangerous actions and correspondencies. For as there are a sort of base and sordid spirits that attend the envy and malice of the ignorant and viler sort of persons, and betray them into compacts by promises of revenge; so, no doubt, there are a kind of more airy and speculative fiends, of a higher rank and order than those wretched imps, who apply themselves to the curious. . . Yea, and sometimes they are so cautious and wary in their conversations with more refined persons, that they never offer to make any express covenant with them. And to this purpose, I have been informed by a very reverend and learned doctor that one Mr. Edwards, a Master of Arts of Trinity College, in Cambridge, being reclaimed from conjuration, declared in his repentance that the demon always appeared to him like a man of good fashion, and never required any compact from him : and no doubt they sort themselves agreeably to the rate, post, and genius of those with whom they converse."*

* Sadducismus Triumphatus, section xri. 
The sentiments of the royal chaplain on demonology are curious. 'Since good men,' he argues, ' in

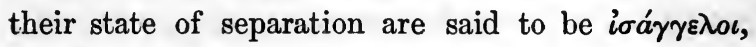
why the wicked may not be supposed to be irooairoves (in the worst sense of the word), I know nothing to help me to imagine. And if it be supposed that the imps of witches are sometimes wicked spirits of our own kind and nature, and possibly the same that have been witches and sorcerers in this life: this supposal may give a fairer and more probable account of many of the actions of sorcery and witchcraft than the other hypothesis, that they are always devils. And to this conjecture I will venture to subjoin another, which hath also its probability, viz. that it is not improbable but the familiars of witches are a vile kind of spirits of a very inferior constitution and nature; and none of those that were once of the highest hierarchy now degenerated into the spirits we call devils. . . . . And that all the superior-yea, and inferior-regions have their several kinds of spirits, differing in their natural perfections as well as in the kinds and degrees of their depravities; which being supposed, 'tis very probable that those of the basest. and meanest sorts are they who submit to the servilities." It is a

* Sadducismus Triumphatus, Part I. sect. 4. Affixed to this work is a Collection of Relations of well-authenticated instances. Glanvil was one of the first Fellows of the recently established Royal Society. 
curious speculation how the old apologists of witchcraft would regard the modern 'curiosos' - the adventurous spirit-media of the present day, and whether the consulted spirits are of 'base and sordid rank,' or are 'a kind of airy and more speculative fiends.' It is fair to infer, perhaps, that they are of the latter class.

The author of the 'Saints' Everlasting Rest,' the moderate and conscientious Baxter, was a contem. porary of the Anglican divine. In another and later work this voluminous theological writer more fully developed his spiritualistic ideas. 'The Certainty of the World of Spirits fully evinced by unquestionable Histories of Apparitions, Witchcrafts, Operations, Voices, \&c., proving the Immortality of Souls, the Malice and Misery of Devils and the Damned, and the Blessedness of the Justified. Written for the Conviction of Sadducees and Infidels,' was a formidable inscription which must have overawed, if it did not subdue, the infidelity of the modern Sadducees.*

$\mathrm{He}$ is the author of a philosophical treatise of great merit-the Scepsis Scientifica-a review of which occupies several pages of The Introduction to the Literature of Europe, and which is farourably considered by Hallam. Not the least unaccountable fact in the history and literature of witcheraft is the absurd contradiction involved in the unbounded credulity of writers (who were sceptical on almost erery other subject) on the one subject of demonology.

* It would not be an uninteresting, but it would be a melancholy, task to investigate the reasoning, or rather unreasoning, process which involved such honest men as Richard Baxter in a maze of 
The sentence and execution of two old women at Bury St. Edmund's, in 1664, has been already noticed. This trial was carried on with circumstances of great solemnity and with all the external forms of justice - Sir Matthew Hale presiding as Lord Chief Baron : and the following is a portion of the evidence which was received two hundred years ago in an English Court of Justice and under the presidency of one of the greatest ornaments of the English Bench. One of the witnesses, a woman named Dorothy Durent, deposed that she had quarrelled with one Amy Duny, immediately after which her infant child was seized with fits. 'And the said examinant further stated that she being troubled at her child's distemper did go to a certain person named Doctor Job Jacob, who lived at Yarmouth, who had the reputation in the country to help children that were bewitched; who advised her to hang up the child's blanket in the chimney-corner all day, and at night when she put the child to bed to put it into the said blanket; and if she found anything in it she should not be

credulity. While they rejected the principle of the ever-recurring ecclesiastical miracles of Catholicism (so sympathetic as well as useful to ardent faith), their devout imagination yet required the aid of a present supernaturalism to support their faith amidst the perplexing doubts and difficulties of ordinary life, and they gladly embraced the consoling belief that the present evils are the work of the enmity of the devil, whose temporary sovereignty, however, should be overthrown in the world to come, when the faith and constancy of his victims shall be eternally rewarded. 
afraid, but throw it into the fire. And this deponent did according to his direction; and at night when she took down the blanket with an intent to put the child therein, there fell out of the same a great toad which ran up and down the hearth; and she, having a young youth only with her in the house, desired him to catch the toad and throw it into the fire, which the youth did accordingly, and held it there with the tongs; and as soon as it was in the fire it made a great and terrible noise; and after a space there was a flashing in the fire like gunpowder, making a noise like the discharge of a pistol, and thereupon the toad was no more seen nor heard. It was asked by the Court if that, after the noise and flashing, there was not the substance of the toad to be seen to consume in the fire; and it was answered by the said Dorothy Durent that after the flashing and noise there was no more seen than if there had been none there. The next day there came a young woman, a kinswoman of the said Amy, and a neighbour of this deponent, and told this deponent that her aunt (meaning the said Amy) was in a most lamentable condition, having her face all scorched with fire, and that she was sitting alone in her house in her smock without any fire. And therefore this deponent went into the house of the said Amy Duny to see her, and found her in the same condition as was related to her; for her face, her legs, and thighs, which this deponent saw, seemed 
very much scorched and burnt with fire; at which this deponent seemed much to wonder, and asked how she came in that sad condition. And the said Amy replied that she might thank her for it, for that she (deponent) was the cause thereof; but she should live to see some of her children dead, and she upon crutches. And this deponent further saith, that after the burning of the said toad her child recovered and was well again, and was living at the time of the Assizes.' The accused were next arraigned for having bewitched the family of Mr. Samuel Pacy, merchant, of Lowestoft. The witch turned away from their door had at once inflicted summary vengeance by sending some fearful fits and pains in the stomach, apparently caused by an internal pricking of pins; the children shrieking out violently, vomiting nails, pins, and needles, and exclaiming against several women of illrepute in the town; especially against two of them, Amy Duny and Rose Cullender.

A friend of the family appeared in court, and deposed: 'At some times the children would see things run up and down the house in the appearance of mice, and one of them suddenly snapt one with the tongs and threw it into the fire, and it screeched out like a bat. At another time the younger child, being out of her fits, went out of doors to take a little fresh air, and presently a little thing like a bee flew upon her face and would have gone into her 
mouth, whereupon the child ran in all haste to the door to get into the house again, shrieking out in a most terrible manner. Whereupon this deponent made haste to come to her; but before she could get to her the child fell into her swooning fit, and at last, with much pain and straining herself, she vomited up a twopenny nail with a broad head; and being demanded by this deponent how she came by this nail, she answered that the bee brought this nail and forced it into her mouth. And at other times the elder child declared unto this deponent that during the time of her fits she saw flies come unto her and bring with them in their mouths crooked pins; and after the child had thus declared the same she fell again into violent fits, and afterwards raised several pins. At another time the said elder child declared unto this deponent, and sitting by the fire suddenly started up and said she saw a mouse; and she crept under the table, looking after it; and at length she put something in her apron, saying she had caught it. And immediately she ran to the fire and threw it in; and there did appear upon it to this deponent like the flashing of gunpowder, though she confessed she saw nothing in the child's hands.' Another witness was the mother of a servant girl, Susanna Chandler, whose depositions are of much the same kind, but with the addition that her daughter was sometimes stricken with blindness and dumbness by 
demoniacal contrivance at the moment when her testimony was required in court. 'Being brought into court at the trial, she suddenly fell into her fits, and being carried out of the court again, within the space of half an hour she came to herself and recovered her speech; and thereupon was immediately brought into the court, and asked by the Court whether she was in condition to take an oath and to give evidence. She said she could. But when she was sworn and asked what she could say against. either of the prisoners, before she could make any answer she fell into her fits, shrieking out in a miserable manner, crying "Burn her! burn her!" which was all the words she could speak.' Doubts having been hazarded by one or two of the less credulous of the origin of the fits and contortions, "to avoid this scruple, it was privately desired by the judge that the Lord Cornwallis, Sir Edmund Bacon, and Mr. Serjeant Keeling and some other gentlemen there in court, would attend one of the distempered persons in the farthest part of the hall whilst she was in her fits, and then to send for one of the witches to try what would then happen, which they did accordingly.' Some of the possessed, having been put to the proof by having their eyes covered, and being touched upon the hand by one of those present, fell into contortions as if they had been touched by the witches.

The suspicion of imposture thus raised was quickly 
silenced by fresh proof. Robert Sherringham, farmer, deposed that 'about two years since, passing along the street with his cart and horses, the axle-tree of his cart touched her house and broke down some part of it; at which she was very much displeased, threatening him that his horses should suffer for it. And so it happened; for all those horses, being four in number, died within a short time after. Since that time he hath had great losses by sudden dying of his other cattle. So soon as his sows pigged, the pigs would leap and caper, and immediately fall down and die. Also, not long after, he was taken with a lameness in his limbs that he could neither go nor stand for some days.'*

The extreme ridiculousness, even more than the iniquity, of the accusations may be deemed the principal characteristic of such procedures : these childish indictments were received with eagerness by prosecutors, jury, and judge. After half an hour's deliberation the jury returned a unanimous verdict against the prisoners, who were hanged, protesting their innocence to the end. The year before, a woman

* This witness finished his evidence by informing the Court that 'after all this, he was very much vexed with a great number of lice, of extraordinary bigness; and although he many times shifted himself, yet he was not anything the better, but would swarm again with them. So that in the conclusion he was forced to burn all his elothes, being two suits of apparel, and then was clear from them.'-Narratives of Sorcery, \&c., from the most authentic sources, by Thomas Wright. 
named Julian Coxe was hanged at Taunton on the evidence of a hunter that a hare, which had taken refuge from his pursuit in a bush, was found on the opposite side in the likeness of a witch, who had assumed the form of the animal, and taken the opportunity of her hiding-place to resume her proper shape. In 1682 three women were executed at Exeter. Their witchcraft was of the same sort as that of the Bury witches. Little variety indeed appears in the English witchcraft as brought before the courts of law. They chiefly consist in hysterical, epileptic, or other fits, accompanied by vomiting of various witch-instruments of torture. The Exeter witches are memorable as the last executed judicially in England.

Attacks upon the superstition of varying degrees of merit were not wanting during any period of the seventeenth century. Webster, who, differing in this respect from most of his predecessors, declared his opinion that the whole of witcheraft was founded on natural phenomena, credulity, torture, imposture, or delusion, has deserved to be especially commemorated among the advocates of common sense. He had been well acquainted in his youth with the celebrated Lancashire Witches' case, and enjoyed good opportunities of studying the absurd obscenities of the numerous examinations. His meritorious work was given to the world in 1677 , under the title of 'The 
Displaying of Supposed Witchcraft.' Towards the close of the century witch-trials still occur; but the courts of justice were at length freed from the reproach of legal murders.

The great revolution of 1688 , which set the principles of Protestantism on a firmer basis, could not fail to effect an intellectual as well as a political change. A recognition of the claims of common sense (at least on the subject of diabolism) seemed to begin from that time; and in 1691, when some of the criminals were put upon their trial at Frome, in Somersetshire, they were acquitted, not without diffculty, by the exertion of the better reason of the presiding judge, Lord Chief Justice Holt. Fortunately for the accused, Lord Chief Justice Holt was a person of sense, as well as legal acuteness; for he sat as judge at a great number of the trials in different parts of the kingdom. Both prosecutors and juries were found who would willingly have sent the proscribed convicts to death. But the age was arrived when at last it was to be discovered that fire and torture can extinguish neither witchcraft nor any other heresy; and the princes and parliaments of Europe seemed to begin to recognise in part the philosophical maxim that, ' heresy and witcheraft are two crimes which commonly increase by punishment, and are never so effectually suppressed as by being totally neglected.' In France, until about the year 1670, there was 
little abatement in the fury or number of the prosecutions. In that year several women had been sentenced to death for frequenting the Domdaniel or Sabbath meeting by the provincial parliament of Normandy. Louis XIV. was induced to commute the sentence into banishment for life. The parliament remonstrated at so astonishing an interference with the due course of justice, and presented a petition to the king in which they insist upon the dread reality of a crime that ' tends to the destruction of religion and the ruin of nations.' *

* 'Your parliament,' protest these legislators, ' have thought it their duty on occasion of these crimes, the greatest which men can commit, to make you acquainted with the general and uniform feelings of the people of this province with regard to them; it being moreover a question in which are concerned the glory of God and the relief of your suffering subjects, who groan under their fears from the threats and menaces of this sort of persons, and who feel the effects of them every day in the mortal and extraordinary maladies which attack them, and the surprising damage and loss of their possessions.' They then review the various laws and decrees of Church and State from the earliest times in support of their convictions : they cite the authority of the Church in council and in its most famous individual teachers. Particularly do they insist upon the opinions of St. Augustin, in his City of God, as irrefragable. 'After so many authorities and punishments ordained by human and divine laws, we humbly supplicate your Majesty to reflect once more upon the extraordinary results which proceed from the malevolence of this sort of people; on the deaths from unknown diseases which are often the consequence of their menaces; on the loss of the goods and chattels of your subjects; on the proofs of guilt continually afforded by the insensibility of the marks upon the accused; on the sudden transportation of bodies from one place to another; on the sacrifices and nocturnal assemblies, and other facts, corroborated by the testi- 
While most of the Governments of Europe were now content to leave sorcerers and witches to the irregular persecutions of the people, tacitly abandoning to the mob the right of proceeding against them as they pleased, without the interference of the law, in a remote kingdom of Europe a witch-persecution commenced with the ordinary fury, under express sanction of the Government. It is curious that at the last moments of its existence as a legal crime, one of the last fires of witchcraft should have been lighted in Sweden, a country which, remote from continental Europe, seems to have been up to that period exempt from the judicial excesses of England, France, or Germany. The story of the Mohra witches is inserted in an appendix to Glanvil's ' Collection of Relations,' by Dr. Anthony Horneck. The epidemic broke out in 1669, in the village of Mohra, in the mountainous districts of Central Sweden. A number of children

mony of ancient and modern authors, and verified by so many eyewitnesses, composed partly of accomplices and partly of people who had no interest in the trials beyond the love of truth, and confirmed moreover by the confessions of the accused parties themselres, and that, Sire, with so much agreement and conformity between the different cases, that the most ignorant persons convicted of this crime have spoken to the same circumstances and in nearly the same words as the most celebrated authors who have written about it; all of which may be easily proved to your Majesty's satisfaction by the records of various trials before your parliaments.'-Given in Memoirs of Extraordinary Popular Delusions. Louis XIV., with an unaccustomed care for human life, resisting these forcible arguments, remained firm, and the condemned were saved from the stake. 
became affected with an imaginative or mischievous disease, which carried them off to a place called Blockula, where they held communion and festival with the devil. These, numbering a large proportion of the youth of the neighbourhood, were incited, it seems, by the imposture or credulity of the ministers of Mohra and Elfdale, to report the various transactions at their spiritual séances. To such a height increased the terrified excitement of the people, that a commission was appointed by the king, consisting of both clergy and laity, to enquire into the origin and circumstances of the matter. It commenced proceedings in August 1670. Days for humiliation and prayer were ordered, and a solemn service inaugurated the judicial examinations. Agreeably to the dogma of the most approved foreign authorities, which allowed the evidence of the greatest criminals and of the youngest age, the commission began by examining the children, three hundred in number, claiming to be bewitched, confronting them with the witches who had, according to the indictment, been the means of the devil's seduction. They were strictly interrogated whether they were certain of the fact of having been actually carried away by the devil in his proper person. Being answered in the affirmative, the royal commissioners proceeded to demand of the accused themselves, "Whether the confessions of those children were true, and admonished them to confess 
the truth, that they might turn away from the devil unto the living God. At first most of them did very stiffly, and without shedding the least tear, deny it, though much against their will and inclination. After this the children were examined every one by themselves, to see whether their confessions did agree or no; and the commissioners found that all of them, except some very little ones, which could not tell all the circumstances, did punctually agree in their confessions of particulars. In the meanwhile, the commissioners that were of the clergy examined the witches, but could not bring them to any confession, all continuing steadfast in their denials, till at last some of them burst out into tears, and their confession agreed with what the children said; and these expressed their abhorrence of the fact, and begged pardon, adding that the devil, whom they called Locyta, had stopped the mouths of some of them, so loath was he to part with his prey, and had stopped the ears of others. And being now gone from them, they could no longer conceal it, for they had now perceived his treachery.' The Elfdale witches were induced to announce-' We of the province of Elfdale do confess that we used to go to a gravel-pit which lies hard by a cross-way, and there we put on a vest over our heads, and then danced round; and after this ran to the cross-way and called the devil thrice, first with a still voice, the second time somewhat 
louder, and the third time very loud, with these words, "Antecessor, come and carry us to Blockula." Whereupon immediately he used to appear, but in different habits; but for the most part we saw him in a grey coat and red and blue stockings.* He had a red beard, a high-crowned hat with linen of divers colours wrapt about it, and long garters about upon his stockings. Then he asked us whether we would serve him with soul and body. If we were content to do so, he set us on a beast which he had there ready, and carried us over churches and high walls, and after all he came to a green meadow where Blockula lies [the Brockenberg in the Hartz forest, as Scott conjectures]. We procured some scrapings of altars and filings of church clocks, and then he gave us a horn with a salve in it, wherewith we do anoint ourselves, and a saddle, with a hammer and a wooden nail thereby to fix the saddle. Whereupon we call upon the devil, and away we go.'

Many interrogatories were put. Amongst others, how it was contrived that they could pass up and down chimneys and through unbroken panes of

* Accommodating himself to modern refinement, the devil usually discards the antiquated horns, hoofs, and tail ; and if, as Dr. Mede supposed, 'appearing in human shape, he has always a deformity of some uncouth member or other,' such inconvenient appendages are disguised as much as possible. As Goethe's Mephistopheles explains to his witch:

'Culture, which renders man less like an ape, Has also licked the devil into shnpe.' 
glass (to which it was replied that the devil removes all obstacles); how they were enabled to transport so many children at one time? \&c. They acknowledged that 'till of late they had never power to carry away children; but only this year and the last: and the devil did at that time force them to it: that heretofore it was sufficient to carry but one of their own children or a stranger's child with them, which happened seldom: but now he dió plague them and whip them if they did not procure him many children, insomuch that they had no peace or quiet for him. And whereas that formerly one journey a week would serve their turn from their own town to the place aforesaid, now they were forced to run to other towns and places for children, and that they brought with them some fifteen, some sixteen children every night.' As to their means of conveyance, they were sometimes men; at other times, beasts, spits, and posts: but a preferable mode was the riding upon goats, whose backs were made more commodious by the use of a magical ointment whenever a larger freight than usual was to be transported. Arrived at Blockula, their diabolical initiation commenced. First they were made to deny their baptism and take an oath of fealty to their new master, to whom they devoted soul and body to serve faithfully. Their new baptism was a baptism of blood: for their lord cut their fingers and wrote their 
names in blood in his book. After other ceremonies they sit down to a table, and are regaled with not the choicest viands (for such an occasion and from such a host)-broth, bacon, cheese, oatmeal. Dancing and fighting (the latter a peculiarity of the Northern Sabbath) ensue alternately. They indulge, too, in the debauchery of the South: the witches having offspring from their intercourse with the demons, who intermarry and produce a mongrel breed of toads and serpents. As interludes, it may be supposed, to the serious part of the entertainment the fiend would contrive various jokes, affecting to be dead; and, a graver joke, he would bid them to erect a huge building of stone, in which they were to be saved upon the approaching day of judgment. ' While engaged at this work he threw down the unfinished house about their ears, to the consternation, and sometimes injury, of his vassals.* Some of the witnesses spoke of a great dragon encircled with flames, and an iron chair ; of a vision of a burning pit. The minister of the district gave his evidence that, having been suffering from a painful headache, he could account for the unusual severity of the attack only by supposing that the witches had celebrated one of

* Le Sage's Diable Boiteur, who so obligingly introduces the Spanish student to the secret realities of human life, is, it may be observed, of both a more rational and more instructire temperament than the ordinary demons who appear at the witches' revels to practise their senseless and fantastic rites. 
their infernal dances upon his head while asleep in bed : and one of them, in accordance with this conjecture, acknowledged that the devil had sent her with a sledge-hammer to drive a nail into the temples of the obnoxious clergyman. The solidity of his skull saved him; and the only result was, as stated, a severe pain in his head.

All the persuasive arguments of the examiners could not induce the witches to repeat before them their well-known tricks: because, as they affirmed, 'since they had confessed all they found all their witchcraft was gone: and the devil at this time appeared very terrible with claws on his hands and feet, with borns on his head and a long tail behind, and showed them a pit burning with a hand out; but the devil did thrust the person down again with an iron fork, and suggested to the witches that if they continued in their confession he would deal with them in the same manner.' These are some of the interesting particulars of this judicial commission as reported by contemporaries. Seventy persons were condemned to death. One woman pleaded (a frequent plea) in arrest of judgment that she was with child; the rest perseveringly denying their guilt. Twenty-three were burned in a single fire at the village of Mohra. Fifteen children were also executed; while fifty-six others, convicted of witcheraft in a minor degree, were sentenced to various punishments: to be scourged 
on every Sunday during a whole year being a sentence of less severity. The proceedings were brought to an end, it seems, by the fear of the upper classes for their own safety. An edict of the king who had authorised the enquiry now ordered it to be terminated, and the history of the commission was attempted to be involved in silent obscurity. Prayers were ordered in all the churches throughout Sweden for deliverance from the malice of Satan, who was believed to be let loose for the punishment of the land.* It is remarkable that the incidents of the Swedish trials are chiefly reproductions of the evidence extracted in the courts of France and Germany.

* Narratives of Sorcery, \&c., by Thomas Wright, who quotes the authorised reports. Sir Walter Scott refers to 'An account of what happened in the kingdom of Sweden in the years 1669, 1670, and afterwards translated out of High Dutch into English by Dr. Anthony Horneck, attached to Glanvil's Sadducismus Triumphatus. The trauslation refers to the evidence of Baron Sparr, ambassador from the court of Sweden to the court of England in 1672, and that of Baron Lyonberg, envoy-extraordinary of the same power, both of whom attest the confessions and execution of the witehes. The King of Sweden himself answered the express inquiries of the Duke of Holstein with marked reserve. "His judges and commissioners," he said, "had caused dirers men, women, and children to be burnt and executed on such pregnant evidence as was brought before them; but whether the actions confessed and proved against them were real, or only the effect of a strong imagination, he was not as yet able to determine.", 


\section{CHAPTER X.}

Witcheraft in the English Colonies in North America-Puritan Intolerance and Superstition-Cotton Mather's 'Late Memorable Providences'-Demoniacal Possession-Evidence given before the Commission-Apologies issued by Authority-Sudden Termination of the Proceedings-Reactionary Feeling against the Agitators-The Salem Witcheraft the last Instance of Judicial Prosecution on a large Scale in Christendom-Philosophers begin to expose the Superstition-Meritorious Labours of Webster, Becker, and others-Their Arguments could reach only the Educated and Wealthy Classes of Society-These only partially Enfranchised-The Superstition continues to prevail among the Vulgar-Repeal of the Witch Act in England in 1736-Judicial and Popular Persecutions in England in the Eighteenth Century-Trial of Jane Wenham in England in 1712 - Maria Renata burned in Germany in 1749-La Cadière in France-Last Witch burned in Scotland in 1722-Recent Cases of Witcheraft-Protestant Superstition-Witcheraft in the Extra-Christian World.

A REVIEW of the superstitions of witchcraft would be incomplete without some notice of the Salem witches in New England. An equally melancholy and mischievous access of fanatic credulity, during the years 1688-1692, overwhelmed the colony of Massachusetts with a multitude of demons and their human accomplices; and the circumstances of the 
period were favourable to the vigour of the delusion. In the beginning of their colonisation the New Englanders were generally a united community; they were little disturbed by heresy; and if they had been thus infected they were too busily engaged in contending against the difficulties and dangers of a perilous position to be able to give much attention to differences in religious belief. But soon the purity of their faith was in danger of being corrupted by heretical immigrants. The Puritans were the most numerous and powerful of the fugitives from political and religious tyranny in England, and the dominant sect in North America almost as severely oppressed Anabaptists and Quakers in the colonies as they themselves, religious exiles from ecclesiastical despotism, had suffered in the old world. They proved themselves worthy followers of the persecutors of Servetus. Other enemies from without also were active in seeking the destruction of the true believers. Fierce wars and struggles were continuously being waged with the surrounding savages, who regarded the increasing prosperity and number of the intruders with just fear and resentment.

Imbued as the colonists were with demoniacal prepossessions, it is not so surprising that they deemed their rising State beset by spiritual enemies; and it is fortunate, perhaps, that the wilds of North America were not still more productive of fiends and witches, 
and more destructive massacres than that of 1690-92 did not disgrace their colonial history. From the pen of Dr. Cotton Mather, Fellow of Harvard College, and his father (who was the Principal), we have received the facts of the history. These two divines and their opinions obtained great respect throughout the colony. They devoutly received the orthodox creed as expounded in the writings of the ancient authorities on demonology, firmly convinced of the reality of the present wanderings of Satan ' up and down' in the earth; and Dr. Cotton Mather was at the same time the chief supporter and the historian of the demoniacal war now commenced. It was significantly initiated by the execution of a papist, an Irishman named Glover, who was accused of having bewitched the daughters of a mason of Boston, by name Goodwin. These girls, of infantile age, suffered from convulsive fits, the ordinary symptom of 'possession.' Mather received one of them into his house for the purpose of making experiments, and, if possible, to exorcise the evil spirits. She would suddenly, in presence of a number of spectators, fall into a trance, rise up, place herself in a riding attitude as if setting out for the Sabbath, and hold conversation with invisible beings. A peculiar phase of this patient's case was that when under the influence of 'hellish charms' she took great pleasure in reading or hearing 'bad' books, which she was permitted to do with perfect 
freedom. Those books included the Prayer Book of the English Episcopal Church, Quakers' writings, and popish productions. Whenever the Bible was taken up, the devil threw her into the most fearful convulsions.

As a result of this diagnosis appeared the publication of 'Late Memorable Providences relating to Witchcraft and Possession,' which, together with Baxter's 'Certainty of the World of Spirits,' a work Mather was careful to distribute and recommend to the people, increased the fever of fear and fanaticism to the highest pitch. The above incidents were the -prelude only to the proper drama of the Salem witches. In 1692, two girls, the daughter and niece of Mr. Parvis, minister, suffering from a disease similar to that of the Goodwins, were pronounced to be preternaturally afflicted. Two miserable Indians, man and wife, servants in the family, who indiscreetly attempted to cure the witch-patients by means of some charm or drug, were suspected themselves as the guilty agents, and sent to execution. The physicians, who seem to have been entirely ignorant of the origin of these attacks, and as credulous as the unprofessional world, added fresh testimony to the reality of 'possession.' * At first, persons of the

* A phenomenon of apparently the same sort as that which was of such frequent occurrence in the Middle Age and in the seventeenth century, is said to hare becn lately occupying considerable attention 
lower classes and those who, on account of their illrepute, would be easily recognised to be diabolic agents, were alone incriminated. But as the excitement increased others of higher rank were pointed out. A black man was introduced on the stage in the form of an Indian of terrible aspect and portentous dimensions, who had threatened the christianising colonists with extermination for intruding their faith upon the reluctant heathen. In May 1692, a new governor, Sir William Phipps, arrived with a new charter (the old one had been suspended) from England; this official, far from discouraging the existing prejudices, urged the local authorities on to greater extravagance. The examinations were conducted in the ordinary and most approved manner, the Lord's Prayer and the secret marks being the infallible tests. Towards the end of May two women, Bridget Bishop and Susannah Martin, were hanged.

On June 2, a formal commission sat, before which the most ridiculous evidence was gravely given and in the South of France. The Courrier des Alpes narrates an extraordinary scene in one of the churches in the Commune of Morzine, among the women, on occasion of the risitation of the bishop of the district. It seems that the malady in question attacks, for the most part, the female population, and the patients are confidently styled, and asserted to be, possessed. It 'produces all the effects of madness, without having its character,' and is said to baffle all the resources of medical science, which is ignorant of its nature. There had been an intermission of the convulsions for some time, but they have now reappeared with greater violence than ever.-The Times newspaper, June 6, 1864. 
as gravely received. John Louder deposed against Bridget Bishop, 'that upon some little controversy with Bishop about her fowls going well to bed, he did awake in the night by moonlight, and did see clearly the likeness of this woman grievously.oppressing him, in which miserable condition she held him unable to help himself till next day. He told Bishop of this, but she denied it, and threatened him very much. Quickly after this, being at home on a Lord's day with the doors shut about him, he saw a black pig approach him, at which he going to kick, it vanished away. Immediately after sitting down he saw a black thing jump in at the window and come and stand before him. The body was like that of a monkey, the feet like a cock's, but the face much like that of a man.* He being so extremely affrighted that he could not speak, this monster spoke to him and said, "I am a messenger sent unto you, for I understand that you are in some trouble of mind, and if you will be ruled by me you shall want for nothing in this world." Whereupon he endeavoured to clap his hands upon it, but he could feel no substance; and it jumped out of window again, but immediately came in by the porch (though the doors were shut) and said, "You had better take my counsel." He then struck at it with a stick, and struck

* 'Rara avis in terris.' A mongrel and anomalous species like the German Meerkatzen-monkey-cats. 
only the ground and broke the stick. The arm with which he struck was presently disabled, and it vanished away. He presently went out at the back door, and spied this Bishop in her orchard going towards her house, but he had no power to set one foot forward to her ; whereupon, returning into the house, he was immediately accosted by the monster he had seen before, which goblin was now going to fly at him; whereat he cried out, "The whole armour of God be between me and you!" so it sprung back and flew over the apple-tree, shaking many apples off the tree in its flying over. At its leap, it flung dirt with its feet against the stomach of the man, whereupon he was then struck dumb, and so continued for three days together.' Another witness declared in court that, ' being in bed on the Lord's day, at night he heard a scrambling at the window; whereat he then saw Susanna Martin come in and jump down upon the floor. She took hold of this deponent's foot, and, drawing his body into a beap, she lay upon him nearly two hours, in all which time he could neither speak nor stir. At length, when he could begin to move, he laid hold on her hand, and, pulling it up to his mouth, he bit some of her fingers, as he judged into the bone; whereupon she went from the chamber down stairs out at the door,' \&c.

On July 19 five women, and on August 19, six persons, were sent to the gallows, among whom was 
Mr. George Burroughs, minister, who had provoked his judges by questioning the very existence of witchcraft. At the last moments he so favourably impressed the assembled spectators by an eloquent address, that Dr. Mather, who was present, found it necessary to prevent the progress of a reactionary feeling by asserting that the criminal was no regularly ordained minister, and the devil has often been transformed into an angel of light. So transparently iniquitous and absurd had their mode of procedure become, that one of the subordinates in the service of the authorities, whose office it was to arrest the accused, refused to perform any longer his hateful office, and being himself denounced as an accomplice, he sought safety in flight. He was captured and executed as a recusant and wizard. Eight sorcerers suffered the extreme penalty of the law on September 22. Giles Cory, a few days before, indignantly refusing to plead, was 'pressed to death,' an accustomed mode of punishing obstinate prisoners; and in the course of this torture, it is said, when the tongue of the victim was forced from his mouth in the agony of pain, the presiding sheriff forced it back with his cane with much sang froid. At this stage in the proceedings, the magistrates considered that a justificatory memoir ought to be published for the destruction of twenty persons of both sexes, and, at the express desire of the governor, Cotton Mather 
drew up an Apology in the form of a treatise, 'More Wonders of the Invisible World,' in which the Salem executions are justified by the precedent of similar and notorious instances in the mother-country, as well as by the universally accepted doctrines of various eminent authors of all ages and countries. Increase Mather,Principal of Harvard College, was also directed to solve the question whether the devil could sometimes assume the shape of a saint to effect his particular design. The reverend author resolved it affirmatively in a learned treatise, which he called (a seeming plagiarism) 'Cases of Conscience concerning Witchcraft and Evil Spirits personating Men,' an undertaking prompted by an unforeseen and disagreeable circumstance. The wife of a minister, one of the most active promoters of the prosecution, was involved in the indiscriminate charges of the informers, who were beginning to aim at more exalted prey. The minister, alarmed at the unexpected result of his own agitation, was now convinced of the falseness of the whole proceeding. It was a fortunate occurrence. From that time the executions ceased.*

The dangerously increasing class of informers who,

* If, howerer, individuals of the human species were at length exempt from the penalty of death, those of the canine species were sacrificed, perhaps vicariously. Two dogs, conricted, as it is reported, of being accessories, were solemnly hanged! 
like the 'delatores' of the early Roman Empire, made a lucrative profession by their baseness, and spared not even reluctant or recusant magistrates themselves, more than anything else, was the cause of the termination of the trials. If they would preserve their own lives, or at least their reputations, the authorities and judges found it was necessary at once to check the progress of the infection. About one hundred and fifty witches or wizards were still under arrest (two hundred more being about to be arrested), when Governor Phipps having been recalled by the Home Government, was induced by a feeling of interest or justice to release the prisoners, to the wonder and horror of the people. From this period a reaction commenced. Those who four years before originated the trials suddenly became objects of hatred or contempt. Even the clergy, who had taken a leading part in them, became unpopular. In spite of the strenuous attempts of Dr. Cotton Mather and his disciples to revive the agitation, the tide of public opinion or feeling had set the other way, and people began to acknowledge the insufficiency of the evidence and the possible innocence of the condemned. Public fasts and prayers were decreed throughout the colony. Judges and juries emulated one another in admitting a misgiving 'that we were sadly deluded and mistaken.' Dr. Mather was less fickle and less repentant. In one of his treatises on 
the subject, recounting some of the signs and proofs of the actual crime, he declares: 'Nor are these the tenth part of the prodigies that fell out among the inhabitants of New England. Fleshy people may burlesque these things: but when hundreds of the most solemn people, in a country where they have as much mother-wit certainly as the rest of mankind, know them to be true, nothing but the froward spirit of Sadduceeism can question them. I have not yet (he confidently asserts) mentioned so much as one thing that will not be justified, if it be required, by the oaths of more considerate persons than any that can ridicule these odd phenomena.' ${ }^{*}$

So ended the last of public and judicial persecutions of considerable extent for witchcraft in Christendom. As far as the superior intellects were concerned, philosophy could now dare to reaffirm that reason 'must be our last judge and guide in everything.' Yet Folly, like Dulness, ' born a goddess, never dies ;' and many of the higher classes must have experienced some silent regrets for an exploded creed which held the reality of the constant personal interference of the demons in human affairs. The fact that the great body of the people of every country in Europe

* Narratives of Sorcery and Magic, chap. xxxi. The faith of the Fellow of Harrard College, we may be inclined to suppose, was quickened in proportion to his doubts. To do him justice, he admitted that some of the circumstances alleged might be exaggerated or eren imaginary. 
remained almost as firm believers as their ancestors down to the present age, hardly needs to be insisted on; that theirs was a living faith is evidenced in the ever-recurring popular outbreaks of superstitious ignorance, resulting both in this country and on the Continent often in the deaths of the objects of their diabolic fear.

Such arguments as those of Webster in England, of Becker and Thomasius in Germany, on the special subject of witchcraft, and the general arguments of Locke or of Bayle, could. be addressed only to the few.* Nor indeed would it be philosophical to expect that the vulgar should be able

* Dr. Balthazar Becker, theological professor at Amsterdum, published his heretical work in Dutch, under the title of 'The World Bewitched, or a Critical Investigation of the commonly-received Opinion respecting Spirits, their Nature, Power, and Acts, and all those extraordinary Feats which Men are said to perform through their Aid ;' 1691. 'He founds his arguments on two grand principles-that from their very nature spirits cannot act upon material beings, and that the Scriptures represent the devil and his satellites as shut up in the prison of hell. To explain away the texts which militate against his system, evidently cost him much labour and perplexity. His interpretations, for the most part, are similar to those still relied on by the belierers in his doctrine' (Note by Murdock in Mosheim's Institutes of Ecclesinstical History). The usually candid Mosheim notices, apparently with contempt, “"The World Bewitched," a prolix and copious work, in which he perverts and explains away, with no little ingenuity indecd, but with no less audacity, whaterer the sacred volume relates of persons possessed by eril spirits, and of the power of demons, and maintuins that the miserable being whom the sacred writers call Satan and the deril, together with his ministers, is bound with ererlasting chains in hell, so that 
to penetrate an inveterate superstition that recently had been universally credited by the learned world.

The cessation of legal procedure against witches was negative rather than positive: the enactments in the statute-books were left unrepealed, and so seemed not to altogether discountenance a still somewhat doubtful prejudice. It was so late as in the ninth year of the reign of George II., 1736, that the Witch Act of 1604 was formally and finally repealed. By a tardy exertion of sense and justice the Legislature then enacted that, for the future, no prosecutions

he cannot thence go forth to terrify mortals and to plot against the righteous.' Balthazar Becker, one of the most meritorious of the opponents of diabolism, was deposed from his ministerial office by an ecclesiastical synod, and denounced as an atheist. His position, and the boldness of his arguments, excited extraordinary attention and animosity, and 'vast numbers' of Lutheran divines arose to confute his atheistical heresy. The impunity which he enjoyed from the vengeance of the devil (he had boldly challenged the deity of hell to avenge his overturned altars) was explained by the orthodox divines to be owing to the superior cunning of Satan, who was certain that he would be in the end the greatest gainer by unbelief. Christ. Thomasius, professor of jurisprudence, was the author of sereral works against the popular prejudice between the years 1701 and 1720. He is considered by Ennemoser to have been able to effect more from his professional position than the humanely-minded Becker. But, after all, the overthrow of the diabolic altars was caused much more by the discoreries of science than by all the writings of literary philosophers. Eren in Southern Europe and in Spain (as far as was possible in that intolerant land) reason began to exhibit some faint signs of existence; and Benito Feyjoo, whose Addisonian labours in the eighteenth century in the land of the Inquisition deserve the gratitude of his countrymen (in his Téatro Critico), dared to raise his voice, howerer feeble, in its behalf. 
should be instituted on account of witcheraft, sorcery, conjuration, enchantment, \&c., against any person or persons. Unfortunately for the credit of civilisation, it would be easy to enumerate a long list of illegal murders both before and since 1736. One or two of the most remarkable cases plainly evincing, as Scott thinks, that the witch-creed 'is only asleep, and might in remote corners be again awakened to deeds of blood,' are too significant not to be briefly referred to. In 1712 Jane Wenham, a poor woman belonging to the village of Walkern, in the county of Hertford, was solemnly found guilty by the jury on the evidence of sixteen witnesses, of whom three were clergymen; Judge Powell presiding. She was condemned to death as a witch in the usual manner; but was reprieved on the representation of the judge. She had been commonly known in the neighbourhood of her home as a malicious witch, who took great pleasure in afflicting farmers' cattle and in effecting similar mischief. The incumbent of Walkern, the Rev. Mr. Gardiner, fully shared the prejudice of his parishioners; and, far from attempting to dispel, he entirely concurred with, their suspicions. A warrant was obtained from the magistrate, Sir Henry Chauncy, for the arrest of the accused : and she was brought before that local official; depositions were taken, and she was searched for ' marks.' The vicar of Ardley, a neighbouring village, tested her guilt or 
innocence. with the Lord's Prayer, which was repeated incorrectly: by threats and other means he forced the confession that she was indeed an agent of the devil, and had had intercourse with him.

But, even in the middle of the eighteenth century, witches were occasionally tried and condemned by judicial tribunals. In the year 1749, Maria or Emma Renata, a nun in the convent of Unterzell, near Würzburg, was condemned by the spiritual, and executed by the civil, power. By the clemency of the prince, the proper death by burning alive was remitted to the milder sentence of beheading, and afterwards burning the corpse to ashes: for no vestige of such an accursed criminal should be permitted to remain. after death. When a young girl Maria Renata had been seduced to witchcraft by a military officer, and was accustomed to attend the witchassemblies. In the convent she practised her infernal arts in bewitching her sister-nuns.* About the same time a nun in the south of France was subjected to the barbarous imputation and treatment of a witch:

* Ennemoser relates the history of this witch from 'The Christian address at the burning of Maria Renata, of the convent of Unterzell, who was burnt on June 21, 1749, which address was delivered to a numerous multitude, and afterwards printed by command of the authorities.' The preacher earnestly insisted upon the divine sanction and obligation of the Mosaic law, "Thou shalt not suffer a witch to live,' which was taken as the text; and upon the fact that, so far from being abolished by Christianity, it was made more imperative by the Christian Church. 
Father Girard, discovering that his mistress had some extraordinary scrofulous marks, conceived the idea of proclaiming to the world that she was possessed of the stigmata-impressions of the marks of the nails and spear on the crucified Lord, believed to be reproduced on the persons of those who, like the celebrated St. Francis, most nearly assimilated their lives to His. The Jesuits eagerly embraced an opportunity of producing a miracle which might confound their Jansenist rivals, whose sensational miracles were threatening to eclipse their own.* Sir Walter Scott states that the last judicial sentence of death for witchcraft in Scotland was executed in 1722, when Captain David Ross, sheriff of Sutherland, condemned a woman to the stake. As for illegal persecution, M. Garinet ('Histoire de la Magie en France') gives

* The rictim of the pleasure, and afterwards of the ambition, of Father Girard, is known as La Cadière. She was a native of Toulon, and when young had witnessed the destructive effects of the plague which derastated that city in 1720. Amidst the confusion of society she was distinguished by her purity and benerolence. The story of La Cadière and Father Girard is eloquently narrated by M. Michelet in La Sorciere. The convulsions of the Flagellants of the thirteenth century, and of the Protestant Reviralists of the present day, exhibit on a large scale the paroxysms of the French convents and the Dutch orphan-houses of the serenteenth century. Nor is diabolical 'possession' yet extinct in Christendom, if the reports received from time to time from the Continent are to be credited. Recently, a conrent of Augustinian nuns at Loretto, on the authority of the Corriere delle Marche of Aneona, was attacked in a similar way to that of Loudun. A romiting of needles and pins, the old diabolical torture, and a strict examination of the accused, followed. 
a list of upwards of twenty instances occurring in France between the years 1805 and 1818. In the latter year three tribunals were occupied with the trials of the murderers.

If a belief should be entertained that the now 'vulgar' ideas of witchcraft have been long obsolete in England, it would be destroyed by a perusal of a few of the newspapers and periodicals of the last hundred years; and a sufficiently voluminous work might be occupied with the achievements of modern Sidrophels, and the records of murders or mutilations perpetrated by an ignorant mob.*

* Without noticing other equally notorious instances of recent years, it may be enough (to dispel any such possible illusion) to transcribe a paragraph from an account in The Times newspaper of Sept. 24, 1863. 'It is a somewhat singular fact,' says the writer, describing a late notorious witch-persecution in the county of Essex, ' that nearly all the sixty or seventy persons concerned in the outrage which resulted in the death of the deceased were of the small tradesmen class, and that none of the agricultural labourers were mixed up in the affair. It is also stated that none of those engaged were in any way under the influence of liquor. The whole disgraceful transaction arose out of a deep belief in witcheraft, which possesses to a lamentable extent the tradespeople and the lower orders of the district.' Nor does it appear that the village of Hedingham (the scene of the witch-murder) claims a superiority in credulity over other villages in Essex or in England. The instigator and chief agent in the Hedingham case was the wife of an innkeeper, who was convinced that she had been bewitched by an old wizard of reputation in the neighbourhood: and the mode of punishment was the popular one of drowning or suffocating in the nearest pond. Scraps of written papers found in the hovel of the murdered wizard revealed the numerous applications by lovers, wives, and other anxious inquirers. Amongst other recent revivals of the 'Black Art' in Southern Europe already referred 
Nor would it be safe to assume, with some writers, that diabolism, as.a vulgar prejudice, is now entirely extirpated from Protestant Christendom, and survives only in the most orthodox countries of Catholicism or in the remoter parts of northern or eastern Europe. Superstition, however mitigated, exists even in the freer Protestant lands of Europe and America; and if Protestants are able to smile at the religious creeds or observances of other sects, they may have, it is probable, something less pernicious, but perhaps almost as absurd, in their own creed.* But, after a despotism of fifteen centuries, Christendom has at

to, the inquisition at Rome upon a well-known English or American 'spiritualist,' when, as we learn from himself, he was compelled to make a solemn abjuration that he had not surrendered his soul to the devil, is significant.

* A modern philosopher has well illustrated this obrious truth (Natural History of Religion, sect. xii.). 'The age of superstition,' says an essayist of some notoriety, with perfect truth, 'is not past ; nor,' he adds, a more questionable thesis, 'ought we to wish it past.' Some of the most eminent writers (e.g. Plutarch, Francis Bacon, Bayle, Addison) have rightly or wrongly agreed to consider fanatical superstition more pernicious than atheism. When it is considered that the scientific philosophy of Aristotle, of more than 2,000 years ago, was revived at a comparatively recent date, it may be difficult not to believe in a cyclic rather than really progressive course of luman ideas, at least in metaphysics. . The fact, remarked by Macaulay, that the two principal sections of Christendom in Europe remain very nearly in the limits in which they were in the sixteenth, or in the middle of the seventeenth century, is incontestable. Nor, indeed, are present facts and symptoms so adrerse, as is generally supposed, to the probability of an ultimate reaction in favour of Catholic doctrine and rule, even among the Teutonic peoples, in the revolutions to which human ideas are continually subject. 
length thrown off the hellish yoke, whose horrid tyranny was satiated with innumerable holocausts. The once tremendous power of the infernal arts is remembered by the higher classes of society of the present age only in their proverbial language, but it is indelibly graven in the common literature of Europe. With the savage peoples of the African continent and of the barbarous regions of the globe, witchcraft or sorcery, under the name of Fetishism, flourishes with as much vigour and with as destructive effects as in Europe in the sixteenth century; and every traveller returning from Eastern or Western Africa, or from the South Pacific, testifies to the prevalence of the practice of horrid and bloody rites of a religious observance consisting of charms and incantations. With those peoples that have no further conception of the religious sentiment there obtains for the most part, at least, the magieal use of sorcery.*

* Among the numerous evidences of recent travellers may be specially mentioned that of the well-known traveller R. F. Burton (The Lake Regions of Central Africa) for the practices of the Eastern Africans. On the African continent and elsewhere, as was the case amongst the ancient Jews, the demons are propitiated by human sacrifices. To what extent witch-superstition obtains among the Hindus, the historian of British India bears witness. 'The belief of witcheraft and sorcery,' says Mr. Mill, 'continues universally prevalent, and is every day the eause of the greatest enormities. It not unfrequently happens that Brahmins tried for murder before the English judges assign as their motire to the crime that the murdered individual had enchanted them. No fewer than five unhappy persons in one district were tried and executed for witcheraft so late 
Superstition, ever varying, at some future date may assume, even in Europe, a form as pernicious or irrational as any of a past or of the present age; for in every age 'religion, which should most distinguish us from beasts, and ought most peculiarly to elevate us as rational creatures above brutes, is that wherein men often appear most irrational and more senseless than beasts themselves.' ${ }^{*}$

as the year 1792. The villagers themselves assume the right of sitting in judgment on this imaginary offence, and their sole instruments of proof are the most wretched of all incantations (History of British India, book ii. 7). A certain instinctive or traditional dread of evil spirits excites the terrors of those peoples who hare no firm belief in the providence or existence of a benevolent Divinity. Even among the Chinese-the least religious nation in the world, and whose trite formula of scepticism, 'Religions are many: Reason is one,' expresses their indifferentism to every form of religion-there exists a sort of demoniacal fear (Huc's Chinese Empire, xix). The diabolic and magic superstitions of the Moslem are displayed in Sale's Korûn and Lane's Modern Egyptians.

* Essay concerning the Human Understanding, book iv. 18. 


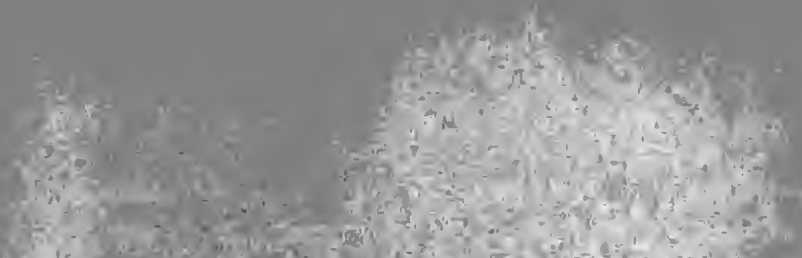

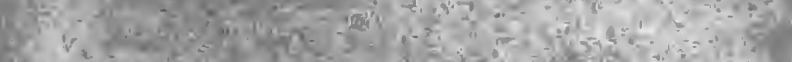

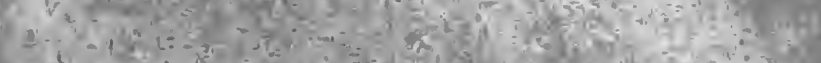
wi How

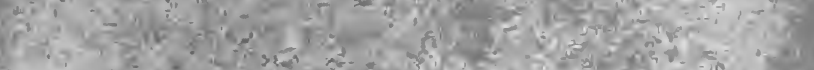

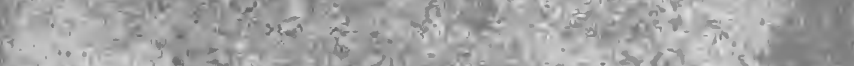
1.

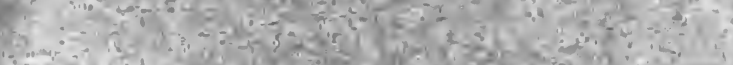

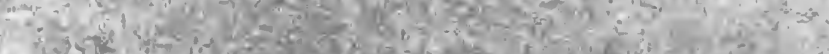

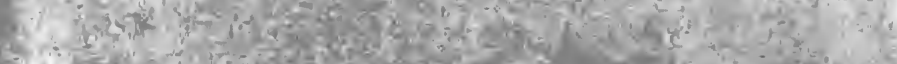

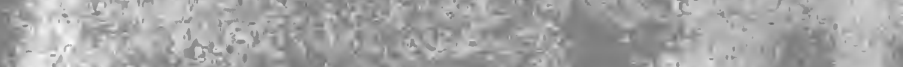

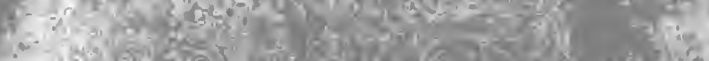

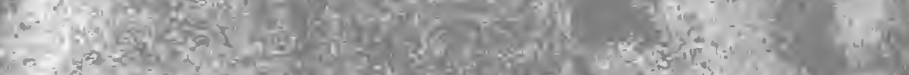

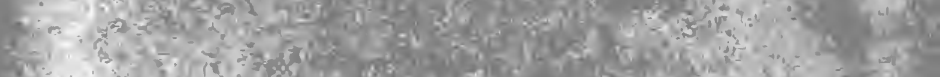

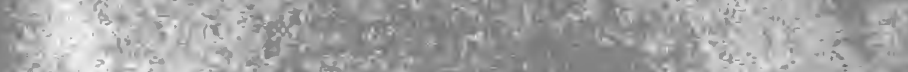

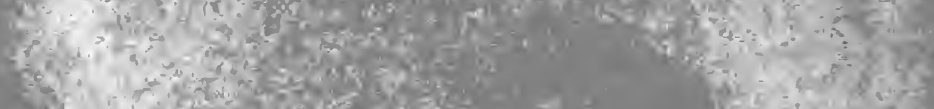

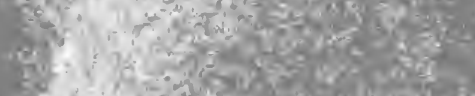

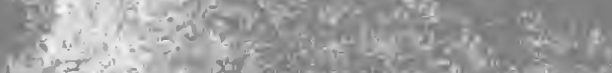
het Ex: $=2$

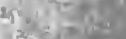

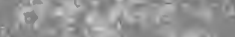

$\therefore x^{2}, 2 x=2 x$

if $\log ^{2}+2=$

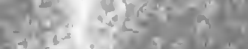

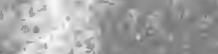

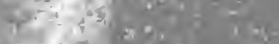

$x \in=-100$

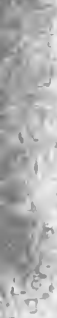

10

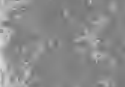

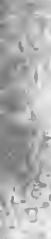

49

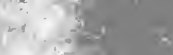

$i^{0} i^{2}=$

at

4.9

$\left(\frac{8}{6} y\right.$

$(x)=$

$x^{2}+x^{2}=$

ide

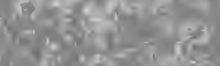

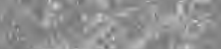

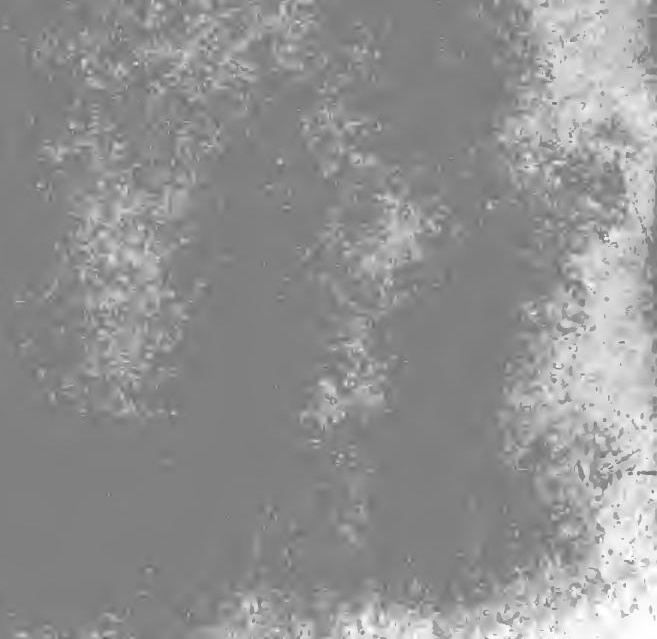

ac.

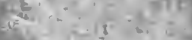

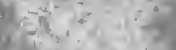

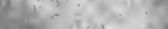
$7-2{ }^{4}=$

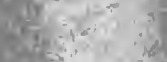
of $-\frac{10}{2}$ Wagar. $\div$ 


\section{GENERAL LIST OF WORKS}

PUBLISHED BY

\section{MESSRS. LONGMAN, GREEN, AND CO.}

\section{PATERNOSTER ROW, LONDON.}

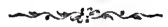

\section{Historical Works.}

The HISTORY of ENGLAND from the Fall of Wolsey to the Death of Elizabeth. By JAmes Antrionx Froude, M.A. late Fellow of Exeter College, Oxford. Third Edition of the First Eight Volumes.

Vous. I to IV. the Reign of Henry VIII. Third Edition, $54 s$.

Vous. V. and VI. the Reigns of Edward VI. and Mary. Third Edition, 2ss.

Vols. VII. and VIII. the Reign of Elizabeth, Vous. I. and II. Third Edition, 28s.

The HISTORY of ENGLAND from the Accession of James II. By Lord MACAULAY. Three Editions as follows.

LibraRY EDImion, 5 vols. 8 vo. $£ 4$.

Cabinet Edition, 8 vols. post 8 vo. $48 s$.

People's Edition, 4 vols. crown 8vo. $16 s$.

REVOLUTIONS in ENGLISH HISTORY. By Robert Vaughas,

D.D. 3 vols. 8 vo. $45 s$.

Vor. I. Revolutions of Race, $\mathbf{1 5 s .}$

Vor II. Revolutions in Religion, 15s.

VoL. III. Revolutions in Government, $15 s$.

The HISTORY of ENGLAND during the Reign of George the Third. By William Massey, Mi.P. 4 vols. 8 vo. 48 s.

The CONSTITUTIONAL HISTORY of ENGLAND, since the Accession of George III. 1760-1860. By Thomas Erssine MaY, C.B. 2 vols. 8vo. 33s.

IIVES of the QUEENS of ENGLAND, from State Papers and other Documentary Sourees : comprising a Domestic History of England from the Conquest to the Death of Queen Anne. By AGNes STRICKLAND. Revised Edit:on, with many Portraits. S vols. post 8 vo. $60 s$. 
LECTURES on the HISTORY of ENGLAND. By WILLIAM LONGMAN. Voc. I. from the earliest times to the Death of King Edward II. with 6 Maps, a coloured Plate, and 53 Woodcuts. 8vo. $15 s$.

A CHRONICLE of ENGLAND, from B.C. 55 to A.D. 1495 ; written and illustrated by J. E. DorLE. With 81 Designs engraved on AFood and printed in Colours by E. Evans. 4to. 42s.

HISTORY of CIVIrISATION. By HeNRY Thomas Buckle. 2 vols. Price $\$ 117 s$.

Vol. I. England and France, Fourth Edition, $21 s$.

For. II. Spain and Scotland, Second Edition, 16 .

DEMOCRACY in AMERICA. By Arexis De Toceueville. Translated by HENRY REEVE, with an Introductory Notice by the Trarislator. 2 vols. 8vo. 21 is.

The SPANISH CONQUEST in AMERICA, and its Relation to the History of Slavery and to the Government of Colonies. By ARTHUR HeLPS. 4 vols. 8vo. \&3. Vous. I. and II. 28s. Vous. III. and IV. 16s. each.

HISTORY of the REFORMATION in EUROPE in the Time of Calvin. By J. H. Merle D'Acbigxe, D.D. Vous. I. and II. Svo. 2ss. and VoL. III. 12s.

IIBRARY HISTORY of FRANCE, in 5 vols. 8vo. By ErRE EvAYs

- Crowe. VoL. I. 14s. Vol. II. 15s. Vox. III. 18s. VoL. IV. nearly ready.

IECTURES on the HISTORY of FRANCE. By the late Sir JAMES STEPHEx, LL.D. 2 vols. 8vo. 24s.

The HISTORY of GREECE. By C. Thirlwal,, D.D., Lord Bishop of St. David's. 8 vols. 8 vo. 23 ; or in 8 vols. fcp. 28 s.

The TALE of the GREAT PERSIAN WAR, from the Histories of Herodotus. By the Rev. G. WV. Cox, M.A. late Scholar of Trin. Coll. Oxon. Fcp. 8vo. 7 s. $6 d$.

ANCIENT HISTORY Of EGYPT, ASSYRIA, and BABYLONIA. By the Author of 'Amy Herbert.' Fcp. 8vo. 6s.

CRITICAL HISTORY of the IANGUAGE and ITTERATURE of Ancient Grecc. By William Murx, of Caldwell. 5 vols. Svo. \&3 $9 s$.

HISTORY of the IITERATURE of ANCIENT GREECE. By Professor K. O. MÚlider. Translated by the Right Hon. Sir George CorveWALL LEWIS, Bart. and by J.JW. DONALDSON, D.D. 3 vols. Svo. 36s.

HISTORY of the ROMANS nnder tho EMPIRE. By the Rer. Charles Merivale, B.D. 7 vols. 8vo. with Maps, £.j.

The FALI of the ROMAN REPUBLIC: a Short History of the Last Century of the Commonwealth. By the Rev. Chardes Merrvale, B.D. 12mo. 7s. $6 d$.

The BIOGRAPHICAL FISTORY of PHILOSOPHY, from its Origin in Greece to the Present Day. By George Henrx Lewes. Revised and enlarged Edition. 8vo. $16 s$.

HISTORY of the INDUCTIVE SCIENCES. By WILLIAM WHEwELL, D.D. F.R.S. Master of Trin. Co!l. Cantab. Third Edition. 3 vols. crown 8vo. $24 s$. 
CRITICAL and HISTORICAL ESSAYS contributed to the Edinburgh Reviev. By the Right Hon. LORD MACAUIAY.

Library Editiox, 3 vols. 8vo. $36 s$.

Traveller's Edition, in 1 vol. $21 s$.

In Pоскет VoluMes, 3 vols. fcp. $21 s$.

People's Edition, 2 vols. crown 8vo. $8 s$.

EGYPT'S PLACE in UNIVERSAL HISTORY; an Historical Investigation. By C. C. J. Buxsen, D.D. Translated by C. H. CotTren, M.A. With many Illustrations. 4 vols. 8 vo. $£ 588$. VoL. V. is nearly ready.

MAUNDER'S HISTORICAL TREASURY ; comprising a General Introductory Outline of Universal History, and a series of Separate Histories. Fep. 8vo. 10s.

HISTORICAL and CHRONOLOGICAL ENCYCLOPEDIA, presenting in a brief and convenient form Chronological Notices of all the Great Events of Universal History. By B. B. WoODWARD, F.S.A. Librarian to the Queen.

[In the press.

HISTORY of CHRISTIAN MISSIONS ; their Agents and their Results By T. W. M. Marsharl. 2 vols. 8 vo. $24 s$.

HISTORY of the EARIY CHURCH, from the First Preaching of the Gospel to the Council of Nicxa, A.D. 325. By the Author of 'Amy Herbert.' Fep. 8vo. 4s. 6d.

HISTORY of WESLEYAN METHODISM. By George SMith, F.A.S. New Edition, with Portraits, in 31 parts. Price $6 d$. each.

FISTORY of MODERN MUSIC; a Course of Lectures delivered at the Royal Institution. By JoHr Hullar, Professor of Vocal Music in King's College and in Queen's College, London. Post 8vo. 6s. $6 d$.

HISTORY of MEDICINE, from the Earliest Ages to the Present Time. By Edward Meriox, M.D. F.G.S. Vol. I. Svo. 12s. $6 d$.

\section{Biography and Memoirs.}

SIR JOHN ELIOT, a Biography : 1590-1632. By JoHN Forster. With Two Portraits on Steel from the Originals at Port Eliot. 2 vols. crown 8 vo. 30 s.

LETTERS and LIFE of FRANCIS BACON, including all his Occasional Works. Colleeted and edited, with a Commentary, by J. SPEDDING, 'Trin. Coll. Cantab. Vols. I. and II. Evo. 24 s.

IIFE of ROBERT STEPHENSON, F.R.S. By J. C. JEAFFreson, Barrister-at-Law; and WilliaM Pole, F.R.S. Memb. Inst. Civ. Eng. With 2 Portraits and many lllustrations.' 2 vols. Svo. [Nearly ready.
[Ne

APOLOGIA pro VITA SUA: being a Reply to a Pamphlet entitled 'What then does Dr. Newman mean?' By JoHr HExkY Newray, D.D. Svo. $14 s$. 
IIFE of the DURE of WEIIINGTON. By the Rev. G. R. GLEIG, M.A. Popular Edition, earefully revised; with copious Additions. Crown 8vo. $5 s$.

Brialmont and Gleig's Life of the Duke of Wellington. 4 rols. Svo. with Illustrations, $£ 214 s$.

Iife of the Duke of Wellington, partly from the French of M. Briaciont, partly from Original Documents. By the Rev. G. R GLEIG, M.A. Svo. with Portrait, $15 s$.

FATHER MATHEW: a Biography. By John Fraxcis Magure, M.P. Second Edition, with Portrait. Post 8vo. 12s.6d.

Rome; its Ruler and its Institutions. By the same Author. New Edition in preparation.

LIFE of AMELIA WILHELMINA SIEVEKING, from the German. Edited, with the Author's sanetion, by CATmerixe Winkworth. Post 8vo. with Portrait, 1:s.

FELIX MENDELSSOHN'S LETTERS from Italy and Switzerland, translated by LADY WALLACE, Third Edition, with Notice of MENDELssoms's Life and Works, by Henry F. CHORLEY; and Letters from 1833 to 1847, transiated by Lady WALLACE. New Edition, with Portrait. 2 vols. erown Sro. $5 s$. each.

DIARIES of a LADY of QUALITY, from 1797 to 1844. Edited, with Notes, by $\Lambda$. Hayward, Q.C. Seeond Edition. Post Svo. 10s. 6d.

RECOLLECTIONS of the late WILLIAM WILBERFORCE, M.P. for the County of York during nearly 30 Yehrs. Hy J. S. HARFoRD, D.C.I. F.R.S. Post 8 vo. $7 s$.

LIFE and CORRESPONDENCE of THEODORE PARKER. By Jous Weiss. With 2 Portraits and 19 Wood Engravings. 2 vols. 8vo. 30 s.

SOUTHEY'S LIFE of WESLEY. Fifth Edition. Edited by the Rev. C. C. Soctuex, M.A. Crown sio. $7 s .6 d$.

THOMAS MOORE'S MEMOIRS, JOURNAL, and CORRESPONDENCE. Edited and abridged from the First Edition by Earl RussELL. Square erown 8vo. with 8 Portraits, 12s. $6 d$.

MEMOIR of the Rev. SYDNEY SMITH. By his Daughter, Lady HoJ,LAxp. With a Selection from his Letters, edited by Mrs. Austix. 2 vols. Svo. 2 ss.

IIFE of WILIIAM WARBURTON, D.D: Bishop of Gloneester from 1760 to 1779. By the Rev.J.S. WAtsox, MI.A. Svo, with Portrait, 1Ss.

FASTI EBORACENSES: Lives of the Archbishops of York. By the late Rev. W. H. Dixos, M.A. Edited and enlarged by the Rev. J. RAINE, II.A. In 2 vols. Vol. I. comprising tho lives to the Death of Edward III. 8vo. $15 s$.

VICISSITUDES of FAMILIES, By Sir BerNard Bunke, Ulster King of Arms. Finst, SECOND, and T'mind SERIEs. 3 vols. crown 8 ro. 12s. $6 d$. each. 
BIOGRAPHICAL SKeTCHeS. By Nassau W. Senior. Post 8vo. price $10 s .6 d$.

ESSAYS in ECCLESIASTICAL BIOGRAPHY. By the Right Hon. Sir J. StePHex, LL.D. Fourth Edition. Svo. 14s.

ARAGO'S BIOGRAPHIES Of DISTINGUISFED SCIENTIFIC IIEN. By Francois Arago. Translated by Admiral W. H. Smyth, F.R.S. the Rev. B. Power, M.A. and R. GRANT, M.A. 8vo. $18 s$.

MAUNDER'S BIOGRAPHICAL TREASURY: Memoirs, Sketehes, and Brief Notices of above 12,000 Eminent Persons of All Ages and Nations. Fep. 8vo. 10 s.

\section{Criticism, Philosophy, Polity, \&c.}

PAPINIAN : a Dialogue on State Affairs between a Constitutional Lawyer and a Country Gentleman about to enter Tublie Life. By Grosge ATKINSON, B.A. Oxon. Serjeant-at-Law. Post 8vo. 5s.

On REPRESENTATIVE GOVERNMENT. By John Stuant Mill. Second Edition, 8vo. $9 s$.

Dissertations and Diseussions. By the same Author. 2 vols. 8vo. priee $24 s$.

0n Liberty. By the same Author. Third Edition. Post 8vo. 7s.6d.

Principles of Political Economy. By the same. Fifth Edition. 2 vols. 8 vo. 30 s.

A System of Logic, Ratiocinative and Inductive. By the same. Fifth Edition. Two vols. 8vo. $25 s$.

Utilitarianism. By the same. 8vo. $5 s$.

LORD BACON'S WORKS, collected and editcd by R. I. ELLIS, M.A. J. SPEDDING, M.A. and D. D. HeATH. Vols. I. to V. Philosophical Works 5 vols. 8vo. \&4 6s. Vous. VI. and VII. Liierary and Professional Works 2 vols. $2116 s$.

BACON'S ESSAYS with ANNOTATIONS. By R. Whately, D.D. late Arehbishop of Dublin. Sixth Edition. 8ro.10s. $6 d$.

ELEMENTS of LOGIC. By R. Whately, D.D. late Archbishop of Dublin. Ninth Edition. 8vo. 10s. $6 d$, erown Svo. $4 s .6 d$.

Elements of Rhetoric. By the same Author. Seventh Edition. 8vo. 10s. $6 d$. crown 8vo. $4 s .6 d$.

English Synonymes. Edited by Archbishop Whately. 5th Edition. Fep. 8vo. 3s.

MISCELLANEOUS REMAINS from the Common-place Book of the late Arehbishop Whately. Edited by MIiss E. J. Wirately. Post Svo. Gs. 
ESSAYS on the ADMINISTRATIONS of GREAT BRITAIN from 1783 to 1830 , contributed to the Edinburgh Review by the Right Hon. Sir G. C. LEwIs, Bart. Edited by the Right Hon. Sir E. HeAD, Bart. 8vo. with Portrait, $15 s$.

By the same Author.

A Dialogue on the Best Form of Government, 4s. $6 d$.

Essay on the Origin and Formation of the Romance Ianguages, price $7 s .6 d$.

Eistorical Survey of the Astronomy of the Ancients, 155.

Inquiry into the Credibility of the Early Roman History, 2 vols. price $30 s$.

On the Methods of Observation and Reasoning in Politics, 2 vols. price $28 s$.

Irish Disturbances and Irish Church Question, 12s.

Remarks on the Use and Abuse of some Political Terms, $9 s$.

On Foreign Jurisdiction and Extradition of Criminals, $2 s .6 d$.

The Fables of Babrins, Greek Text with Latin Notes, Parr I. 5s. 6d. PART II. $3 s .6 d$.

Suggestions for the Application of the Egyptological Method to Modern History, $1 s$.

An OUTLINE of the NECESSARY LAWS of THOUGHT: a Treatise on Pure and Applied Logie. By the Most Rev. W. Thомsor, D.D. Archbishop of York. Crown 8vo. 5s. $6 d$.

The ELements of LoGIC. By Thonas Shedden, M.A. of St. Peter's Coll. Cantab. Crown 8vo.

[Just ready.

ANALYSIS of Mr. MILL'S SYSTEM of LOGIC. By W. STEBbiNG, M.A. Fellow of Worcester College, Oxford. Post 8vo. [Just ready.
[Ju

SPEECHES of the RIGHT HON. LORD MACAULAY, corrected by Himself. 8vo. 12s.

IORD MACAULAY' SPEECHES ON PARIIAMENTARY REFORM. in 1831 and 1832. 16mo. $1 s$.

A DICTIONARY of the ENGLISH IANGUAGE. By R. G. LATHAM, M.A. M.D. F.R.S. Founded on that of Dr. Jomsson, as edited by the Rev. H. J. TODD, with numerous Lmendations and Additions. Publishing in $\mathbf{3 6}$ Parts, price $3 s .6 d$. each, to form 2 vols. 4 to.

The English Language. By the same Author. Fifth Edition. 8vo. price $18 s$.

Handbook of the English Ianguage. By the same Author. Fourth Edition. Crown 8vo. 7s, 6 $l$.

Elements of Comparative Philology. By the same Author. 8vo. $21 s$. 
THESAURUS of ENGLISH WORDS and PHRASES, classified and arranged so as to facilitate the Expression of Ideas, and assist in Literary Composition. By P. M. Roget, M. D. 14th Edition. Crown 8vo. 10s. $6 d$.

IECTURES on the SCIENCE of IANGUAGE, delivered at the Royal Institution. By MAX MuLLER, M.A. Fellow of All Souls College, Oxford. First Series, Fourth Edition. 8vo. 12s. Second SERIEs, with 31 Woodcuts, price $18 s$.

The DEBATER; a Series of Complete Debates, Outlines of Debates, and Questions for Discussion. By F. RowTox. Fep. 8vo. 6s.

A COURSE of ENGLISH READING, adapted to every taste and capacity; or, How and What to Read. By the Rev. J. PICROFT, B.A. Fep. 8vo. 5s.

MANUAL of ENGLISH LITERATURE, Historical and Critical: with a Chapter on English Metres. By T. Anxold, B.A. Prof. of Eng. Lit. Cath. Univ. Ireland. Post 8vo. 10s. 6d.

SOUTHEY'S DOCTOR, complete in One Volume. Edited by the Rev. J. W. WARTER, B.D. Square crown 8vo. 12s. $6 d$.

HISTORICAL and CRITICAL COMMENTARY on the OID TESTAMENT; with a New Translation. By M. M. KALISCH, Ph.D. Vor. I. Genesis, 8vo. 18s. or adapted for the General Reader, 12s. VoL. II. Exodus, $15 s$. or adapted for the General Reader, $12 s$.

A Hebrew Grammar, with Excrcises. By the same. Part I. Outlines with Exercises, 8vo. 12s. 6d. KEY, 5s. PART II. Exceptional Forms and Constructions, $12 s .6 d$.

A NEW LATIN-ENGLISH DICTIONARY. By the Rev. J. T. White, M.A. of Corpus Christi College, and Rev. J. E. RIDDLE, M.A. of St. Edmund Hall, Oxford. Imperial svo. 42s.

A Diamond Latin-English Dictionary, or Guide to the Meaning, Quality, and Accentuation of Latin Classical Words. By the Rev. J. E. RIDDLE, M.A. $32 \mathrm{mo} .4 s$.

A NEW ENGLISH-GREEK IEXICON, containing all the Greek Words used by Writers of good authority. By C. D. YoNGE, B.A. Fourth Edition. 4to. 21s.

A LEXICON, ENGLISH and GREEK, abridged for the Use of Sehools from his ' English-Greek Lexieon' by the Author, C. D. YoxGE, B.A. Square $12 \mathrm{mo}$.

[Just ready.

A GREEK-ENGLISH IEXICON. Compiled by H. G. Lindelr, D.D. Dean of Christ Chureh, and R. ScotT, D.D. Master of Balliol. Fifth Edition. Crown 4to. 31s. 6 cl.

A Lexicon, Greek and English, abridged from Liddecl and Scotr's Greek-English Lexicon. Tenth Edition. Square 12mo. 7 s. $6 d$.

A PRACTICAL DICTIONARY of the FRENCH and ENGLISH IANGUaGes. By L. Contaxsead. 7th Edition. Post 8vo. 10s. $6 d$.

Contanseau's Pocket Dietionary, French and English ; being a close Abridgment of the above, by the same Author. 2nd Edition. 18mo. 5s. 
NEW PRACTICAL DICTIONARY of the GERMAN IANGUAGE; German-English and English-German. By the Rev. W. I. BrACKI.EY, M.A. and Dr. Carl Martin Friedia NDer. Post 8vo. [In the press.

\section{Miscellaneous Works and Popular Metaphysics.}

RECREATIONS of a COUNTRY PARSON : being a Selection of the Contributions of A. K. H. B. to Fraser's Magazine. SECOND SERIEs. Crowu 8 vo. $3 s, 6 d$.

The Common-place Philosopher in Town and Country. By tle saine Author. Crown 8vo. 3s. $6 d$.

Leisure Hours in Town; Essays Consolatory, Esthetical, Moral, Social, and Domestic. By the same. Crown 8vo. 3s. $6 d$.

The Antumn Holidays of a Country Parson. By the same Anthor. 1 vol.

[Nearly ready.

FRIENDS in COUNCIL : a Series of Readings and Discourses thereon. 2 vols. fcp. 8 vo. $9 s$.

Friends in Council, Second Series, 2 vols. post 8vo. $14 s$.

Essays written in the Intervals of Business. Fcp. 8vo. 2s. 6d.

Companions of My Solitude. By the same Author. Fcp. 8vo.3s.6d.

LORD MACAULAY'S MISCELLANEOUS WRITINGS: comprising

his Contributions to KNIGHT's Quarterly Magazine, Articles from the Edinburgh Review not included in his Critical and Historical Essays, Biographies from the Encyclopedia Britannica, Miscellaneous Poems and Inscriptions. 2 vols. 8vo. witl Portrait, 218.

The REV. SYDNEY SMITH'S MISCELLANEOUS WORKS ; including his Contributions to the Edinburgh Review.

Library Editiox. 3 vols. 8vo. $36 s$.

TRAVELLER's EDItIox, in 1 vol. $21 s$.

In Pocket Voldues. 3 vols. 21s.

PeOple's Edition. 2 vols. crown 8vo. $8 s$.

Elementary Sketches of Moral Philosophy, delivered at the Royal Institution. By the same Author. Fep. 8vo. $7 s$.

The Wit and Wisdom of Sydney Smith: a Selection of the most memorable Passages in his Writings and Conversation. 16mo. 7s. G $\mathrm{d}$.

From MATTER to SPIRIT: the Result of Ten Years' Fxperience in Spirit Manifestations. By C. D. with a preface by A. B. Post Svo. 8s. 6d.

The HISTORY of the SUPERNATURAL in All Ages and Nations, and in all Churches, Christian and Pagan; Demonstrating a Universal Faith. By WILLIL HOWITT. 2 vols. post Svo. $18 s$.

Chapters on MENTAL PHysiology. By Sir Henry Holland, Bart. M.D. F.R.S. Second Edition. P'ost $\delta$ vo. $8 \varepsilon$. Gd. 
ESSAYS selected from CONTRIBUTIONS to the Edinburgh Review. By HeNry Rogers. Second Edition. 3 vols. fep. $21 s$.

The Eclipse of Faith; or, a Visit to a Religious Sceptic. By the same Author. Tenth Edition. Fcp. 8vo. $5 s$.

Defence of the Eclipse of Faith, by its Author; a rejoinder to Dr. Newman's Reply. 'Third Edition. Fep. 8vo.3s. 6d.

Selections from the Correspondence of R. E. H. Greyson. By the same Author. Third Edition. Crown 8vo. $7 s .6 d$.

Fulleriana, or the Wisdom and Wit of Thomas Foller, with Essay on his Life and Genius. By the same Author. 16mo. 2s.6d.

Reason and Faith, reprinted from the Edinburgh Review. By the same Author. Fourth Edition. Fcp. 8vo. 1s. $6 d$.

An INTRODUCTION to MENTAL PHILOSOPHY, on the Inductive Method. By. J. D. Morell, M.A. LL.D. 8vo. 12s.

Elements of Psychology, containing the Analysis of the Intellectual l'owers. By the same Author. Post 8vo. 7s. $6 d$.

The SENSES and the INTELLECT. By Alexander Bain, M.A. Professor of Logic in the University of Aberdeen. Second Edition. 8vo. Irice $15 s$.

The Emotions and the Will, by the same Author; completing a Systematic Exposition of the Human Mind. 8vo.15s.

On the Study of Character, including an Estimate of Phrenology. By the same Author. 8vo. $9 s$.

HOURS WITH THE MYSTICS: a Contribution to the History of Religious Opinion. By Robert Alfred Vaughax, B.A. Second Edition. 2 vols. crown 8 vo. $12 s$.

PSYCHOLOGICAT INQUIRIES, or Essays intended to illustrate the Influence of the Physical Organisation on the Mental Faculties. By Sir B. C. Brodie, Bart. Fep. 8vo. 5s. PART II. Essays intended to illustrate some Points in the Physical and Moral History of Man. Fcp. Svo.5s.

The PHILOSOPHY of NECESSITY; or Natural Law as applicable to Mental, Moral, and Social Science. By Cmanles Bray. Second Edition. 8 vo. $9 s$.

The Education of the Feelings and Affections. By the same Author. Third Edition. 8vo. $3 s .6 d$.

CHRISTIANITY and COMMON SENSE. By Sir WILLOdGHBY Joves, Bart. M.A. Trin. Coll. Cantab. 8vo. $6 s$.

Astronomy, Meteorology, Popular Geography, \&·c.

DUTLINES of ASTROHOMY. By Sir J. F. W. Henschel, Bart. M.A. Seventh Edition, revised; with Plates and Woodcuts. 8vo.18s. 
ARAGO'S POPUlaR ASTRONOMY. Translated by Admiral W. H. SMyth, F.R.S. and R. GRANT, M.A. With 25 Plates and 358 Woodcuts. 2 vols. 8vo. £2 $5 s$.

Arago's Meteorological Essays, with Introduction by Baron HomBOLDT. Translated under the superintendence of Major-General E. SABINE, R.A. 8vo. 18s.

The WEATHER-B00K; a Manual of Practical Meteorology. By Rear-Admiral RoBERT FITz Roy, R.N. F.R.S. Third Edition, with 16 Diagrams. 8vo. 15s.

SAXBY'S WEATHER SYSTEM, or Lunar Infinence on Weather, By S. M. SAXBY, R.N. Principal Instructor of Naval Engineers, H.M. Stcam Reserve. Second Edition. Post 8vo. 4s.

DOVE'S LAW of STORMS considered in connexion with the ordinary Movements of the Atmosphere. Translated by R. H. Scorr, M.A. T.C.D. 8vo. 10s. $6 d$.

CELESTIAI OBJECTS for COMMON TELESCOPES. By the Rev. T. W. WEBB, M.A. F.R.A.S. With Map of the Moon, and Woodcuts. 16mo.7s.

PHYSICAI GEOGRAPHY for SCHOOLS and GENERAI READERS. By M. F. MAURT, LL.D. Anthor of 'Physical Geography of the Sea,' \&c. Fcp. Svo. with 2 Plates, $2 s$. $6 d$.

A DICTIONARY, Geographical, Statistical, and Historical, of the various Countries, Places, and Principal Natural Objects in the World. By J. R. M'CuLlocI, Esq. With 6 Maps. 2 vols. 8vo. $63 s$.

A GENERAI DICTIONARY of GEOGRAPHY, Descriptive, Physical, Statistical, and Historical: forming a complete Gazetteer of the World. By A. KeIth Jomsston, F.R.S.E. 8vo. 30s.

A MANUAI of GEOGRAPHY, Physical, Industrial, and Political. By W. Hugmes, F.R.G.S. Professor of Geography in King's College, and in Queen's College, London. With 6 Maps. Fep. 8vo. 7s. $6 d$.

Or in Two Parts:-PART I. Europe, 3s. 6d. PART II. Asia, Africa, America, Australasia, and Polynesia, 48 .

The Geography of British History; a Geographical description of the British Islands at Successive Periods, from the Earliest Times to the Present Day. By the same. With 6 Maps. Fcp. 8vo. 8s. $6 d$.

The BRITISH EMPIRE; a Sketch of the Geography, Growth, Natural and Political Features of the United Kingdom, its Colonies and Dependencies. By Caroline BraT. With 5 Maps. Fep. 8vo. 7s, $6 d$.

COLONISATION and COLONIES : a Series of Lectures delivered before the University of Oxford. By Herman Menivale, M.A. Professor of Political Economy. Svo. 18s.

The AFRICANS at HOME : a popular Description of Africa and the Africans. By the Rev. R. M. Macbrair, M.A. Second Edition; including an Account of the Discovery of the Source of the Nile. With Map and 70 Woodeuts. Fep. 8vo. 58.

MAUNDER'S TREASURY of GEOGRAPHY, Physical, Historical, Descriptive, and Political. Completed by W. HeGres, F.R.G.S. With 7 Maps and 16 Plates. Pep. 8vo. 108. 


\section{Natural History and Popular Science.}

The ELEMENTS of PHYSICS or NATURAL PHILOSOPHY. BY NeIl ARNotT, M.D. F.R.S. Physician Extraordinary to the Queen. Sixth Edition. Part I. 8vo. 10s. $6 d$.

HEAT CONSIDERED as a MODE of MOTION; a Course of Lecture. delivered at the Royal Institution. By Professor JoHN TxNDaLr, F.R.S. Crown 8vo. with Woodcuts, $12 s .6 d$.

VoLCANOS, the Character of their Phenomena, their Share in the Structure and Composition of the Surface of the Globe, \&c. By G. PouLETT ScropE, M.P. F.R.S. Second Edition. 8vo. with illustrations, 15s.

A TREATISE on ELECTRICITY, in Theory and Practice. By A. DE LA RIVE, Prof. in the Academy of Geneva. Translated by C. V. WALKER, F.R.S. 3 vols. 8 vo. with Woodeuts, \&3 13s.

The CORRELATION of PHYSICAI FORCES. By W. R. Grove, Q.C. V.P.R.S. Fourth Edition. 8vo. 7s. 6d.

The GEOLOGICAI MAGAzINE; or, Monthly Journal of Geology Edited by T. Rupert Jonks, F.G.S. Professor of Geology in the R. M. College, Sandhurst; assisted by J. C. Woodward, F.G.S. F.Z.S. British Museum. 8vo. with Illustratious, price 1s. $6 d$. monthly.

A GUIDE to GEOLOGY. By J. Phulurs, M.A. Professor of Geology in the University of Oxford. Fifth Edition; with Plates and Diagrams. Fep. 8vo. $4 s$.

A GLOSSARY of MINERALOGY. By H. W. BRISTOw, F.G.S. of the Geological Survey of Great Britain. With 486 Figures. Crown 8 vo. 12s.

PHILLIPS'S ELEMENTARY INTRODUCTION to IIINERATOGY, with extensive Alterations and Additions, by H. J. BRooke, F.R.S. and W. H. Miller, F.G.S. Post Svo. with Woodeuts, $18 s$.

VAN DER HOEVEN'S HANDBOOK of ZOOLOGY. Translated from the Second Dutch Edition by the Rev. W. CLARK, MI.D. F.R.S. 2 vols. 8 vo. with 24, Plates of Figures, $60 \mathrm{~s}$.

The COMPARATIVE ANATOMY and PHYSIOLOGY of the VERTEbrate Animals. By Richand Owex, F.R.S. D.C.L. 2 vols. 8vo. with upwards of 1,200 Woodcuts.

[In the press.

HOMES WITHOUT HANDS : an Account of the Habitations constructed by various Animals, elassed according to their Principles of Construction. By Rev. J. G. WOOD, M.A. F.L.S. Illustrations on Wood by G. Pearson, troin Drawings by F. W. Keyl and E. A. Smith. In course of publication in 20 Parts, $1 s$. each.

MANUAL of CELENTERATA. By J. ReaY GREene, B.A. M.R.I.A. Edited by the Rev. J. A. Galbraitir, M.A. and the Rev. S. HaUghton, M.D. Fep. Svo, with 39 Woodeuts. 5s.

Manual of Protozoa; with a General Introduction on the Principles of Zoology. By the same Author and Editors. Fep. svo. with 10 Woodeuts, $2 s$.

Manual of the Metalloids. By J. ApJorn, M.D. F.R.S. and the same Editors. Fep. 8 vo. with 38 Woodeuts, $7 s .6 d$. 
THE ALPS: Sketches of Life and Nature in the Mountains. BF Baron H. Vox Berlepscir. Translated by the Rev. L. StepHeN, M.A. With 17 Illustrations. 8vo.15s.

The SEA and its IIVING WONDERS. By Dr. G. Hartwig. Second (English) Edition. 8vo. with many Illustrations. 18s.

The TROPICAL WORLD. By the same Anthor. With 8 Chromoxylographs and 172 Woodcuts. 8vo. $21 s$.

SKETCHES of the NATURAL HISTORY of CEYLON. By Sir J. Eyerson TeNexix, K.C.S. LL.D. With 82 Wood Engravings. Post 8vo. price $12 s .6 d$.

Ceylon. By the same Author. 5th Edition; with Maps, \&c. and 90 Wood Engravings. 2 vols. 8 vo. \&2 $10 s$.

MARVELS and MYSTERIES of INSTINCT; or, Curiosities of Animal Life. By G. Garratt. Third Edition. Fep. 8vo. $7 \mathrm{~s}$.

HOME WALKS and HOLIDAY RAMBLES. By the Rev. C. A. Jorrs, B.A. F.L.S. Fcp. 8vo. with 10 Illustrations, $6 s$.

KIRBY and SPENCE'S INTRODUCTION to ENTOMOLOGY, or Elements of the Natural History of Insects. Scventh Edition. Crown 8vo. price $5 s$.

MAONDER'S TREASURY of NATURAL HISTORY, or Popular Dictionary of Zoology. Revised and corrected by T. S. CoBboLD, M.D, Fcp. 8vo. with 900 Woodcuts, $10 s$.

The TREASURY of BOTANY, on the Plan of Maunder's Treasury. By J. LINDLEY, M.D. and 'T. Moore, F.L.S. assisted by other Practical Botanists. With 16 Plates, and many Woodcuts from designs by W. H. Fitch. Fep. 8vo.

[In the press.

The ROSE AMATEUR'S GUIDE. By Thomas Rivers. 8th Edition. Fep. 8vo. 4s.

The BRITISH FLORA; comprising the Phænogamous or Flowering Plants and the Ferns. By Sir W.J. HookeR, K.H. and G. A. WALKER ARNOTT, LL.D. 12mo. with 12 Plates, 14s, or coloured, $21 s$.

BFYOLOGIA BRITANNICA; containing the Mosses of Great Britain and Ireland, arranged and described. By W. Wilsor. 8vo. with 61 Plates 42s. or coloured, $£ 44$.

The INDO0R GARDENER. By Miss Maling. Fcp. 8vo. with coloured Frontispiece, $5 s$.

LOUDON'S ENCYCLOPEDIA of PLANTS; comprising the Specific Character, Description, Culture, History, \&c. of all the Plants found in Great Britain. With upwards of 12,000 Woodcuts. 8vo. $2313 s .6 d$.

Loudon's Encyclopædia of Trees and Shrubs; containing the Hardy Trees and Shrubs of Great Britain scientifically and popularly described. With 2,000 Woodeuts Svo. 50s.

HISTORY or the BRITISH FRESHWATER ALGE. By A. H. HAssALL, M.D. With 100 Plates of Figures. 2 vols. 8vo. price $£ 1$ 15s. 
IIAUNDER'S SCIENTIFIC and IITERARY TREASURY; a Popular Encyclopredia of Science, Literature, and Art. Fcp. 8 vo. $10 \mathrm{~s}$.

A DICTIONARY of SCIENCE, IITERATURE and ART; comprising the History, Description, and Scientific Principles of every Branch of Human Knowledge. Edited by W. T. Brande, F.R.S.L. and E. Fourth Edition, revised and corrected.

[In the press.

ESEAYS on SCIENTIFIC and other SUBJECTS, contributed to the Edinburgh and Quarterly Reviews. By Sir H. Hollaxd, Bart. M.D. Second Edition. 8vo. 14s.

ESSAYS from the EDINBURGH and QUARTERLY REVIEWS; with Addresses and other pieces. By Sir J. F. W. HERscheL, Bart, M.A. 8vo. 18s.

\section{Chemistry, Medicine, Surgery, and the Allied Sciences.}

A DICTIONARY of CHEMISTRY and the Allied Branches of other Sciences; founded on that of the late Dr. Ure. By HenkY WATTS, F.C.S. assisted by eminent Contributors. 4 vols. Svo. in course of publication in Monthly Parts. VoL. I. $31 s$. $6 \mathrm{~d}$. and VoL. II. 26 s. are now ready.

HANDBOOK of CHEMICAL ANALYSIS, adapted to the Unitary System of Notation: Based on Dr. H. Wills'Anleitung zur chemischen Analyse. By F. T. Conington, M.A. F.C.S. Post 8vo. $7 s$. 6d.-TABLes of QUALITATIVE ANALYSIS to accompany the same, $2 s, 6 d$.

A HANDBOOK of VOLUMETRICAL ANALYSIS. By ROBERT H. ScotT, M.A. T.C.D. Post Svo. 4s.6d.

ELEMENTS of CHEMISTRY, Theoretical and Practical. By Willram A. Miller, M.D. LL.D. F.R.S. F.G.S. Professor of Chemistry, King's College, London. 3 vols. 8 vo. $\& 212 s$. P'ART I. ChEMICAL PHYSICS. Third Edition enlarged, 12s. PART II. INoRgaxic CIIENiISTRY. Second Edition, 20s. PART III. Organic Chemistry. Second Edition, $20 s$.

A MANUAL of CHEMISTRY, Descriptive and Theorctical. By William Odling, M.B. F.R.S. Lecturer on Cliemistry at St. Bartholomew's Hospital. PART I. 8vo. $9 s$.

A Course of Practical Chemistry, for the us? of Medical Students. By the same Author. PART I. crown 8vo. with Woodcuts, 4s.6d. PART II. (completion) just ready.

The DIAGNOSIS and TREATMENT of the DISEASES of WOMEN; including the Diagnosis of Pregnancy. By Graily Hewitt, M.D. Physician to the British Lying-in Hospital. 8vo. 1 fis.

LECTURES on the DISEASES of INFANCY and CHILDHOOD. By Charles West, M.D. \&c. Fourth Edition, revised and enlarged. 8vo. 14s.

EXPOSITION of the SIGNS and SYMPTOMS of PREGNANCX: with other Papers on subjects connected with Mirlwifery. By W. F. MoNTGOMERX, M.A. M.D. M.R.I.A. 8vo. with Illustrations, $25 s$. 
A SYSTEM of SURGERT, Theoretical and Practical. In Treatises by Various Authors, arrauged and edited by T. Horses, M.A. Cantab. Assistant-Surgeon to St. George's Hospital. 4 vols. 8vo.

Vol. I. General Pathology. $21 s$.

Vol. II. Iocal Injuries-Diseases of the Eye. $21 s$.

Vo1. III. Operative Surgery. Diseases of the Organs of Special Sense, Respiration, Circulation, Locomotion and Imnervation. 21s.

Vol. IV. Diseases of the Alimentary Canal, of the Urino-genitary Organs, of the Thyroid, Mamma and Skin; with Appendix of Miscellaneous Subjects, and GENERAL INDEX.

[Early in October.

LECTURES on the PRINCIPLES and PRACTICE of PHYSIC. By Thomas Watson, M.D. Physician-Extraordinary to the Queen. Fourth Edition. 2 vols. 8 vo. 34 s.

IECTURES on SURGICAI PATHOLOGY. By J. PAGET, F.R.S. Surgeon-Extraordinary to the Queen. Edited by W. TuRNer, M.B. 8vo. with 117 Woodcuts, $21 s$.

A TREATISE on the CONTINUED FEVERS of GREAT BRITAIN. By C. Murchrson, M.D. Senior Physician to the London Fever Hospital. 8vo. with coloured Plates, $18 s$.

DEMONSTRATIONS of MICROSCOPIC ANATOMY; a Guide to the Examination of the Animal Tissues and Fluids in Health and Disease, for the use of the Medical and Veterinary Professions. Founded on a Course of Lectures delivered by Dr. HARLEY, Prof. in Univ. Coll. London. Edited by G. T. Brows, late Vet. Prof, in the Royal Agric. Coll. Cirencester. 8vo. with Illustrations.

[Nearly ready.

ANATOMY, DESCRIPTIVE and SURGICAL. BY HENRT GRAY, F.R.S. With 410 Wood Engravings from Dissections. Third Edition, by T. Holmes, M.A. Cantab. Royal 8vo. $28 s$.

PHYSIOLOGICAL ANATOMY and PHYSIOLOGY of MAN. By the late R. B. TODD, M.D. F.R.S. and W. Bowmax, F.R.S. of King's College. With numerous Illustrations. VoL. II. 8 vo. $25 s$.

A New Edition of the FIRST VOLUME, by Dr. Lionel S. Beale, is preparing for publication.

Tho CYCLOP EDIA of ANATOMY and PHYSIOLOGY. Edited by the late R. I3. ToDn, M.D. F.R.S. Assisted by nearly all the most eminent cultivators of Physiological Science of the present age. 5 vols. 8vo. witli 2,853 Woodcuts, $\& 6$ is.

A DICTIONARY of PRACTICAI MEDICINE. By J. CoPland, M.D. F.R.S. Abridged from the larger work by the Author, assisted by J. C. Coplaxd, 1 vil. Sro.

[In the press.

Dr. Copland's Dictionary of Practical Medicine (the larger work). 3 vols. 8 vo. $\& 511 s$.

The WORKS of SIR B, C. BRODIE, Bart. Editcd by Charles H.WKIxs, F.R.C.S.E. 2 vols. 8 vo. [In the press. 
MEDICAL NOTES and REFLECTIONS. By Sir H. Holland, Bart. M.D. Third Edition. 8vo. 18s.

HOOPER'S MEDICAL DICTIONARY, or Eneyclopædia of Medical Science. Ninth Edition, brought down to the present time, by ALEX. HENRY, M.D. 1 vol. 8 vo.

[In the press.

A MANUAL of MATERIA MEDICA and THERAPEUTICS, abridged from Dr. Pereirs's Elements by F. J. FARRE, M.D. Cantab. assisted by R. BENTLEY, M.R.C.S. and by R. WARRIYGTON, F.C.S. 1 vol. 8vo.

Dr. Pereira's Elements of Materia Medica and Therapeutics, Third Edition. By A. S. TAYLor, M.D. and G. O. REES, M.D. \& vols. 8vo. with numerous Woolcuts, \&3 158.

\section{The Fine Arts, and Illustrated Editions.}

The NEW TESTAMENT of OUR LORD and SAVIOUR JESUS CHRIST. Illustrated with numerous Engravings on Wood from the OLD MASTERS. Crown 4to. price 63s. cloth, gilt top; or price $£ 5$ 5s. elegantly bound in morocco.

[In October.

LYRA GERMANICA; Hymns for the Sundays and Chief Festivals of the Christian Year. Translated by CATHERINE WINklvorTH: 125 Illus. trations on Wood drawn by J. LeIGHToN, F.S.A. Fep. 4to. $21 s$.

CATS' and FARIIE'S MORAI EMBLEIS; with Aphorisms, Adages, and Proverbs of all Nations: comprising 121 Illustrations on Wood by J. LeIGHToN, F.S.A. with an appropriate 'I'ext by R. PIGotT. Inperial 8vo. $31 s .6 d$.

BUNYAN'S PILGRIM'S PROGRESS: with 126 Illustrations on Stecl and Wood by C. Bennett ; and a Preface by the Rev. C. Krngslex. Fep. 4to. $21 s$.

The HISTORY of OUR IORD, as exemplified in Works of Art: with that of His Types, St. John the Baptist, and other Persons of the Old and New Testament. By Mrs. JAMEson and Lady EAsTLAkE. Being the Fourth and concluding SERIEs of 'Sacred and Legendary Art;' with 31 Etchings and 281 Woodeuts. 2 vols. square crown 8 vo. 42 s.

In the same Serics, by Mrs. Jamesox.

Legends of the Saints and Martyrs. Fourth Edition, with 19 Etchings and 187 Woodcuts. 2 vols. 31 s. $6 d$.

Legends of the Monastic Orders. Third Edition, with 11 Etchings and 88 Woodcuts. 1 vol. $21 s$.

Legends of the Madonna. Third Edition, with 27 Etchings and 165 Woodcuts. 1 vol. $21 s$.

$$
\text { Arts, Manufactures, gec. }
$$

ENCYCLOPEDIA of ARCHITECTURE, Historical, Theoretical, and Practical. By Josepir Gwilt. With more than 1,000 Woodeuts. 8vo. 42s. 
TUSCAN SCULPTORS, their Lives, Works, and Times. With Illustrations from Original Drawings and Photographs. By CirarLes C. PERKINs. 2 vols. imperial $8 \mathrm{vo}$.

In the press.

The ENGINEER'S HANDBOOK; explaining the Principles which should guide the young Engineer in the Construction of Machinery. By C. S. Lowndes. Post 8vo. 5s.

The ELEMENTS of MECHANISM, for Students of Applied Mechanics. By T. M. Goonere, M.A. Professor of Nat. Philos. in King's Coll. London. With 206 Woodeuts. Post 8vo. 6s. $6 d$.

URE'S DICTIONARY Of ARTS, MANUFACTURES, and MINES. Re-written and enlarged by RoBERT HUNT, F.R.S. assistrd by numerons. gentlemen eminent in Science and the Arts. With 2,000 Woodcuts. 3 vols. Svo. \&4.

ENCYCLOPEDIA of CIVIL ENGINEERING, Historical. Theoretical, and Practical. Ry E. CRESY, C.E. With above 3,000 Woodeuts. 8vo. 42s.

TREATISE on MILLS and MILLWORK. By W. FaIrbairn, C.E. F.R.S. With 18 Plates and 322 Woodeuts. 2 vols. 8 vo. $32 s$. or each vol. scparately, $16 s$.

Useful Information for Engineers. By the same Author. Finst and SECOND SERIES, with many Plates and Woodcuts. 2 vols. crown Svo. $21 s$. or cach vol. separately, $10 s .6 d$.

The Application of Cast and Wrought Iron to Building Purposes. By the same Author. Third Edition, with Plates and Woodents.

[Nearly ready.

The PRACTICAL MECHANIC'S JOURNAL: An Illustrated Record of Mechanical and Engineering Science, and Epitome of Patent Inventions. 4 to. price $1 s$. monthly.

The PRACTICAL DRAUGHTSMAN'S BOOK of INDUSTRIAL DESIGN. By W. JoIrssox, Assoc. Itst. C.E. With many hundred Illustrations. 4to. $28 s .6 d$.

The PATENTEE'S MANUAL; a Treatiso on the Law and Practice of Ietters Patent for the uso of Patentees and Inventors. By J. and J. H. JoHsson. Post Svo. $7 s, 6 d$.

The ARTISAN CLUB'S TREATISE on the STEAM ENGINE, in its various Applications to Mines, Mills, Steam Navigation, Railways and Agriculture. By J. Bodrne, C.E. Fiftli Edition; with 37 Plates and 546 Woodcuts. 4to. $42 s$.

A Catechism of tho Steam Engine, in its various Applications to Mines, Mills, Steam Navigation. Railways, and Agriculture. By the same Author. With 80 Woodcuts. Fep. svo. $6 s$.

The STORY of the GUNS. By Sir J. Emerson Tennent, K.C.S. F.R.S. Witl 33 Woodcuts. Post 8vo. $7 s, 6 d$.

The THEORY of WAR Illnstratel by numerous Examples from History. By Licut.Col, P. L. MACDotGald. Thivd Edition, with 10 Plans. Post 8vo. 10s.6d. 
COIIIERIES and COLLIERS; A Handbook of the Law and leading. Cases relating thereto. By J. C. FowLER, Barrister-at-Law. Fep. 8vo. Gs.

The ART of PERFUMERY; the History and Theory of Odours, and the Methods of Extracting the Aromas of Plants. By Dr. Piesse, F.C.S. Third Edition, with 53 Wocdeuts. Crown 8vo. 10s. 6a.

Chemical, Natural, and Physical Magic, for Juveniles during the Holidays. By the same Author. With 30 Woodcuts. Fep. 8vo. 3s.6d.

The Iaboratory of Chemical Wonders: a Scientific Mélange for Young People. By the same. Crown Svo. 5s. $6 d$.

TALPA; or the Chronicles of a Clay Farm. By C. W. Hoskrss, Esq. With 24 Woodcuts from Designs by G. Crulkshaxk. 16mo. 5s.6d.

H,R.H. the PRINCE CONSORT'S FARMS: An Agricultural Memoir. By Jolix Chalmers Mortox. Dedicated by permission to Her Majesty the QueEx. With 40 Wood Engravings. 4to. 52s.6 .

Handbook of Farm Labour, Steam, Water, Wind, Horse Power, Hand Power, \&c. By the same Author. 16mo. $1 s, 6 d$.

Handbook of Dairy Husbandry; comprising the Gencral Management of a Dairy Farm, \&c. By the same. 16mo. 1s. $6 \mathrm{~d}$.

LOUDON'S ENCYCLOPAEIA of AGRICULTURE: comprising the Laying-out, Improvement, and Management of Landed Property, and the Cultivation and Economy of the Productions of Agriculture. With 1,100 Woodeuts. 8vo. $31 s, 6 d$.

Ioudon's Encylopædia of Gardening: Comprising the Theory and Practice of Horticulture, Floriculture, Arboriculture, and Landscape Gardening. With 1,000 Woodcuts. 8vo.31s. 6 d.

Ioudon's Encyclopædia of Cottage, Farm, and Villa Architecture and Furniture. With more than 2,000 Woodcuts. 8vo. 42s.

MISTORY of WINDSOR GREAT PARK and WINDSOR FOREST. By WilliaM Mievzies, Resident Deputy Surveyor. Dedicated by permission to $\mathbf{H}$. M. the QuxEN. With 2 Maps, and 20 Photographs by the EARL of CaItinNess and Mr. Bembridge. Imperial folio, $£ 8 s$.

BAYLDON'S ART of VALUING RENTS and TILLAGES, and Claims of Tenants upon Quitting Farms, both at Michaelmas and Lady-Day. Eighth Edition, adapted to the present time by J.C. MorTox.

\section{Religious and Moral Works.}

An EXPOSITION of the 39 ARTICLES, Historical and Doctrinal. By E. Harold Browne, D.D. Lord Bishop of Ely. Sixth Edition, 8vo. 16s.

The Pentateuch and the Elohistic Psalms, in reply to Bishop Colenso. By the same Author. Svo. $2 s$.

Examination Questions on Bishop Browne's Exposition of the Articles. By the Rev. J. Gorle, M.A. Fep. $3 s .6 d$. 
FIVE LECTURES on the CHARACTER of ST. PAUL; being the Hulsean Lectures for 1862. By the Rev. J. S. Howsor, D.D. Second Edition. 8vo.9s.

A CRITICAL and GRAMMATICAL COMMENTARY on ST. PAUL'S Epistles. By C. J. Ellicotr, D.D. Lord Bishop of Gloucester and Bristol. 8vo.

Galatians, Third Edition, 8s. 6d.

Ephesians, Third Edition, 8s. $6 d$.

Pastoral Epistles, Second Edition, 10s. 6d.

Philippians, Colossians, and Philemon, Second Edition, 10s. $6 d$.

Thessalonians, Second Edition, 7s. $6 d$.

Historical Lectures on the Life of our Lord Jesus Christ: being the Hulsean Lectures for 1859. By the same. Third Edition. 8vo. 10s. 6d.

The Destiny of the Creature; and other Sermons preached before the University of Cambridge. By the same. Post 8vo. 5s.

The Broad and the Narrow Way; Two Sermons preached before the University of Cambridge. By the same. Crown 8vo. $2 s$.

Rev. T. H. HORNE'S INTRODUCTION to the CRITICAI STUDY and Knowledge of the Holy Scriptures. Eleventh Edition, correctod and extended under careful Editorial revision. With 4 Miaps and 22 Woodcuts and Facsimiles. 4 vols. svo. $£ 313 s$. $6 d$.

Rev. T. H. Horne's Compendious Introduction to the Study of the Bible, being an Analysis of the larger work by the same Author. Re-edited by the Rev. Joms AYre, M.A. With Maps. \&c. Post 8vo. 9s.

The TREASURY of BIBLE KNOWLEDGE, on the Plan of Mander's Treasuries. By the Rev. JoIrN A XRE, M.A. Fep. 8vo. with Maps and. Hlustrations.

[In the press.

The GREEK TESTAMENT; with Notes, Grammatical and Exegetical. By the Rev. W. Webster, M.A. and the Rev. W. F. Wilkinson, M.A. 2 vols. 8vo. $\& 248$.

Vox. I. the Gospels and Acts, 20s.

Vox. II. the Epistles and Apocalypse, $24 s$.

The FOUR EXPERIMENTS in Church and State; and the Conflicts of Churches. By Lord ROBERT Moxt AGU, M.P. 8vo. 12s.

EVERY-DAY SCRIPTURE DIFFICULTIES explained and illustrated; Gospels of St. Matthew and St. Mark. By J. E. Pnescotr, M.A. late Fellow of C. C. Coll. Cantab. 8vo.9s.

The PENTATEUCH and BOOK of JOSHUA Critically Examined. By J. W. Colenso, D.D. Lord Bishop of Natal. Part I. the Pentatench examined as an Historical Narrative. Svo. 6s. PART II. the Age and Authorship of the Pentateuch Considered, 7s. 6d. PART III. the Book of Deuteronomy, 8s. PART IV. the First 11 Chapters of Genesis examined and separated, with Remarks on the Creation, the Fall, and the Deluge, 10s.6d. 
The IIFE and EPISTLES of ST. PAUL. By W. J. Conybeare, M.A. late Fellow of Trin. Coll. Cantab. and J. S. Howsox, D.D. Principal of the Collegiate Institution, Liverpool.

LIBRARY EDITION, with all the Original Illustrations, Maps, Landscapes on Steel, Woodcuts, \&c. 2 vols. 4 to. $48 s$.

INTERM EDIATE EdrTion, with a Selection of Maps, Plates, and Woodcuts. 2 vols. square crown 8 vo. $31 s .6 d$.

Peoples's EDition, revised and condensed, with 46 Illustrations and Maps. 2 vols. crown 8 vo. $12 s$.

The VOYAGE and SHIPWRECK of ST. PAUL; with Dissertations. on the Ships and Navigation of the Ancients. By JAMes Surrtr, F.R.S. Crown 8vo. Charts, $8 s$. $6 d$.

HIPPOLYTUS and his AGE; or, the Beginnings and Prospects of Christianity. By Baron Bunsex, D.D. 2 vols. 8 vo. 30 s.

Outlines of the Philosophy of Universal History, applied to Language and Religion : Containing an Account of the Alphabetical Conferences. By the same Author. 2 vols. 8vo. 33s.

Analecta Ante-Nicæna. By the same Author. 3 vols. 8vo. $42 s$.

THEOLOGIA GERManICA. Translated by SusanNah Winkworth: with a Preface by the Rev. C. KrygsLEY ; and a Letter by Baron Bursen. Fcp. 8vo. 5s.

INSTRUCTIONS in the DOCTRINE and PRACTICE of CHRIStianity, as an Introduction to Confirmation. By G. E. L. Cotrox, D.D. Lord Bishop of Calcutta. 1Smo. $2 s .6 d$.

ESSAYS on RELIGION and ITERATURE. By Cardinal WiseMAN, Dr.D. ROCK, F. H. LAING, and other. Writers. Edited by H. E. MaNNING, D.D. 8vo.

ESSAYS and REVIEWS. By the Rev. W. Temple, D.D. the Rev. R. Williams, B.D. the Rev. B. Poweld, M.A. the Rev. H. B. Wilson, B.D. C. W. Goodwin, M.A. the Rev. M. Pattison, B.D. and the Rev. B.' JowETT, M.A. 11th Edition. Fep. 8vo. 5s.

MOSHEIN'S ECCLESIASTICAL HISTORY. MURDOCK and SOAMES'S Translation and Notes, re-edited by the Rev. W. STuBBs, M.A. 3 vols. Svo. $45 s$.

The GENTIZE and the JEW in the Courts of the Temple of Christ : an Introduction to the History of Christianity. From the German of Prof. Döllinger, by the Rev. N. DARNELL, M.A. 2 vols. 8 vo. $21 s$.

PHYSICO-PROPHETICAI ESSAYS, on the Locality of the Eternal Inheritance, its Nature and Character; the Resurrection Body; and the Mutual Recognition of Glorified Saints. By the Rev. W. LISTER, F.G.S. Crown 8vo. $6 s$.

BISHOP JEREMY TAYLOR'S ENTIRE WORKS: With Life by BrsHop HEBER. Revised and corrected by the Rev. C. P. EDEN, 10 vols. 8 vo. $£ 55 s$. 
PASSING THOUGHTS on RELIGION. By the Author of 'Amy Herbert.' 8th Edition. Fep. 8vo. 5s.

Thoughts for the Holy Week, for Young Persons. By the same Author. 2d Edition. Fep. 8vo. 2s.

Night Lessons from Scripture. By the same Author. 2d Edition. $32 \mathrm{mo} .3 s$.

Self-Examination before Confirmation. By the same Author. $32 \mathrm{mo}$. price $1 s .6 d$.

Readings for a Month Preparatory to Confirmation, from Writers of the Early and English Church. By the same. Fep. 4s.

Readings for Every Day in Lent, compiled from the Writings of Bishop Jeremy 'TA YLoR. By the same. Fcp. 8vo. $5 s$.

Preparation for the Holy Communion; the Devotions chiefly from the works of Jeremy TaYLoR. By the same. 32mo. $3 s$.

MORNING CLOUDS. Second Edition. Fep. 8vo. $5 s$.

The Afternoon of Life. By the same Author. Second Edition. Fep. 5s.

Problems in Human Nature. By the same. Post 8ro. 5s.

The WIFE'S MANUAL; or, Prayers, Thoughts, and Songs on Several Occasions of a Matron's Life. By the Rev. W. CALVERT, M.A. Crown Svo. price $10 s .6 d$.

SPIRITUAL SONGS for the SUNDAYS and HOLIDAYS throughout the Year. By J. S. B. MoxseLL, LL.D. Vicar of Egham. Third Edition. Fep. 8vo. 4s. $6 d$.

HYMNOLOGIA CHRISTIANA : or, Psalms and Hymns selected and arranged in the order of the Christian Seasons. By B. II. KENNEDY, D.D. Prebendary of Lichfield. Crown 8vo. $7 s .6 d$.

IYRA SACRA; Hymns, Ancient and Modern, Odes and Fragments of Sacred Poetry. Edited by the Rev. B. W. SAviLE, M.A. Fep. Svo. $5 s$.

IYRA GERMANICA, translated from the German by Miss C. WiNKworth. First SERIEs, Hymns for the Sundays and Chicf Festivals; Second Series, the Christian Life. Fep. 8 vo. $5 s$, each Series.

Hymns from Lyra Germanica, 18mo. $1 s$.

IYRA EUCHARISTICA; Hymns and Verses on the Holy Communion, Aneient and Modern: with other Poems. Edited by the Rev. ORBY Sirp. LEY, M.A. Second Edition, revised and enlarged. Fep. 8vo. $7 s .6 d$.

Lyra Messianica; Hymns and Verses on the Life of Christ, Aneient and Modern; with other Poems. By the same Editor. Fep. 8vo. $7 s .6 d$.

Iyra Mystica; Hymns and Verses on Sacred Subjects, Ancient and Modern. Forming a companion volume to the above, by the same Editor. Fep. 8vo.

[Nearly ready. 
IYRA DOMESTICA; Christian Songs for Domestic Edification. Translated from the Psaltery and Harp of C. J. P. SPITTA, and from other sources, by RICHARD MASSIE. First and SEcond SERIEs, fep. 8vo. price $4 s$. $6 d$. each.

The CHORALE BOOK for ENGLAND; a complete Hymn-Book in accordance with the Services and Festivals of the Church of England: the Hymus translated by Miss C. WiNKworTH; the tunes arranged by Prof. W. S. BENNETT and OTTO GOLDSCHMIDT. Fep.4to.10s.6d.

Congregational Edition. Fcp. 8vo. price 1s. $6 d$.

$$
\text { Travels, Voyages, \&ंc. }
$$

EASTERN EUROPE and WESTERN ASIA. Political and Social Sketches on Russia, Greecc, and Syria. By Henry A. Tillex. With 6 Illustrations. Post 8vo. $10 \mathrm{~s} .6 \mathrm{~d}$.

EXPLORATIONS in SOUTH-WEST AFRICA, from Walvisch Bay to Lake Ngami and the Victoria Falls. By Thomas BAINes. 8vo. with Map and Illustrations.

[In October.

SOUTH AMERICAN SKETCHES; or, a Visit to Rio Janeiro, the Organ Mountains, La Plata, and the Parana. By THomas W. Hinchuiff, H.A. F.R.G.S. Post 8vo. with Illustrations, 12s. $6 d$.

EXPLORATIONS in LABRADOR. By HeNRY Y. HIND, M.A. F.R.G.S. With Maps and Illustrations. 2 vols. 8vo. 32s.

The Canadian Red River and Assinniboine and Saskatchewan Exploring Expeditions. By the same Author. With Maps and Illustrations. 2 vols. 8 vo. $42 s$.

The CAPITAL of the TYCOON; a Narrative of a Three Years' Residence in Janan. By Sir Rutherford ALCOCK, K.C.B. 2 vols. 8vo. with numerous Iilustrations, $42 s$.

TAST WINTER in ROME and other ITALIAN CITIES. By C. R. WELD, Author of 'The Pyrenees, West and East,' \&c. 1 vol. post 8vo. with a Portrait of 'SteLLA,' and Engravings on Wood from Sketehes by the Author.

[.In the Autumn.

AUTUMN RAMBLES in NORTH AFRICA. By JOHN ORMSBY, of the Middle Temple, Author of the 'Ascent of the Grivola,' in 'Peaks, Passes, and Glacicrs.' With 13 Illustrations on Wood from Sketches by the Author. Post 8vo. 8s. 6 d.

PEAKS, PASSES, and GLACIERS; a Serics of Excursions by Members of the Alpine Club. Edited by J. BALI, MI.R.I.A. Fourth Edition; Maps, Illustrations, Woodcuts. Square erown 8vo.21s.-TrAvELLERS' EDITION, condensed, $16 \mathrm{mo} .5 s .6 d$.

Second Series, edited by E. S. Kennedy, M.A. F.R.G.S. With many Maps and Illustrations. 2 vols. square crown 8 vo. 4: $s$.

Iineteen Iraps of the Alpine Districts, from the First and Second Series of Peaks, Passes, and Glaciers, Price $7 s .6 d$. 
The DOLOMITE MOUNTAINs. Excursions through Tyrol, Carinthia, Carniola, and Friuli in 1861, 1662, and 1863. By J. GLLBERT and G. C. CHURCHIL, F.R.G.S. With numerous Illustrations. Square crown 8vo. $21 s$.

MOUNTAINEERING in 1861; a Vacation Tour. By Prof. J. TrNDALL, F.R.S. Square crown 8vo. with 2 Views, 7s.6d.

A SUMMER TOUR in the GRISONS and ITALIAN VALLEYS of the Bernina. By Mrs. Hexry Fresirfend. With 2 Coloured Maps and 4 Views. Post 8vo. 10s.6d.

Alpine Byeways; or, Light Leaves gathcred in 1859 and 1860 . By the same Authoress. Post 8vo. with Illustrations, 10s. $6 d$.

A IADY'S TOUR ROUND MONTE ROSA; including Visits to the Italian Valleys. With Map and Illustrations. Post 8vo. 14s.

GUIDE to the PYRENEES, for the use of Mountaineers. By Charlas Packe. With Maps, \&c. and a new Appendix. Fcp. $6 s$.

GUIDE to the CENTRAI ALPS, including the Bernese Oberland, Eastern Switzerland, Lombardy, and Western Tyrol. By JoH A BALx, M.R.I.A. Post 8vo. with 8 Maps, 78. 6d. or with an INTRODdCrion on Alpine Travelling, and on the Geology of the Alps, $8 s .6 d$. The INTroDUcION separately, $1 s$.

Guide to the Western Alps. By the same Author. With an Article on the Gcology of the Alps by M. E. DEsor. Post 8vo. with Maps, \&c. $7 s .6 d$.

A WEEK at the IAND'S END. By J. T. BLIGHT; assisted by E. H. Rodn, R. Q. Couch, and J. RALFs. With Map and $\$ 6$ Woodcuts. Fcp. 8vo. 6s.6d.

VISITS to REMARKABLE PLACES: Old Halls, Battle-Fields, and Scenes Illustrative of Striking Passages in English History and Poetry. By WILIIAN Howitr. 2 vols. square crown 8vo. with Wood Engravings, price $25 s$.

The RURAI IIFE of ENGLAND. By the same Author. With Woodcuts by Bewick and Williams. Medium 8vo.12s.6 $d$.

\section{Works of Fiction.}

LATE LAURELS : a Tale. By the Author of 'Wheat and Tares.' 2 vols. post Svo. 158 .

GRYLL GRANGE. By the Author of 'Headlong Hall.' Post 8vo. price $7 s .6 d$.

A FIRST FRIENDSHIP. [Reprinted from Fraser's Magazine.] Crown 8vo. 7s. $6 d$.

ThalatTA ; or, the Great Commoner : a Political Romance. Crown 8vo. 9s. 
ATHERSTONE PRIORY. By L. N. Comyn. 2 vols. post 8vo. $21 s$. Ellice : a Tale. By the same. Post 8vo. 9s. 6d.

The LAST of the OLD SQUIRES. By the Rev. J. W. WARTER, B.D. Second Edition. Fep. 8vo. $4 s .6 d$.

TALES and STORIES by the Author of 'Amy Herbert,' uniform Edition, each Story or Tale in a single Volume.

AMT HERBERT, 2s.6 $d$.

GERTRUDE, $2 s, 6 d$.

EARL'S DAU GHTER, $2 s .6 d$.

Experience of Life, $2 s .6 d$.

Cleve Hall, $3 s .6 d$.

Ivors, $3 s .6 d$.

KATHARINE AsmTon, 3s. 6d.?

Margaret Percival, $5 s$.

Laneton Parsonage, $4 s .6 d$.

URSUlA, 4s. 6 d.

A Glimpse of the World. By the Author of 'Amy Herbert.' Fcp. 7s. $6 d$.

ESSAYS on FICTION ; comprising Articles on Sir W. Scotr, Sir E. B. LytTon, Colonel Senior, Mr. ThaCkeray, and Mrs. Beecher Stowe. Reprinted chiefly from the Edinburgh, Quarterly, and Westminster Reviews; with large Additions. By Nassau W. Sexior. Post 8vo. 10s.6d.

The GLAdiators : A Tale of Rome and Judæa. By G. J. Whrts Melvilue. Crown 8vo.

Digby Grand, an Autobiography. By the same Author. 1 vol. $5 s$.

Kate Coventry, an Autobiography. By the same. 1 vol. $5 s$.

General Bounce, or the Lady and the Locusts. By the same. 1 vol. $5 s$.

Holmby House, a Tale of Old Northamptonshire. 1 vol. $5 s$.

Good for Nothing, or All Down Hill. By the same. 1 vol. $6 s$.

The Queen's Maries, a Romance of Holyrood, 1 vol. $6 s$.

The Interpreter, a Tale of the War. By the same. I vol. $5 s$.

TALES from GREEK MYTHOLOGY. By the Rev. G. W. Cox, M.A. late Scholar of Trin. Coll. Oxon. Second Edition. Square 16mo. 3s. $6 d$.

Tales of the Gods and Heroes. By the same Author. Second Edition. Fep. Svo. $5 s$.

Tales of Thebes and Argos. By the same Author. Fcp. 8vo. 4s.6d.

The WARDEN: a Novel. By Anthony Trollope. Crown 8vo.3s. $6 d$.

Barchester Towers: a Sequel to 'The Warden.' By the same Author. Crown 8vo. $5 s$.

The SIX SISTERS of the VALLEYS: an Historical Romance. By W. BRAMLEY-MOORE, M.A. Incumbent of Gerrard's Cross, Bucks. With 14 Illustrations on Wood. Crown 8vo. $5 s$. 


\section{Poetry and the Drama.}

MOORE'S POETICAI WORKS, Cheapest Editions complete in 1 vol. including the Autobiographical Prefaces and Author's last Notes, which are still copyright. Crown 8vo. ruby type, with Portrait, $7 s$. $6 d$. or People's Edition, in larger type, $12 s, 6 d$.

Moore's Poetical Works, as above, Library Edition, medium 8ro. with Portrait and Vignette, $21 s$. or in 10 vols. fep. $3 s .6 d$. eael.

TENNIEL'S EDITION of MOORE'S IALIA ROOKH, with 68 Wood Engravings from original Drawings and other Illustrations. Fcp. 4to. 21 s.

Moore's Lalla Rookh. 32mo. Plate, 1s. 16mo. Vignctte, 2s. $6 d$. Square crown 8vo. with 13 Plates, 15s.

MACLISE'S EDITION of MOORE'S IRISH MELODIES, with 161 Steel Plates from Original Drawings. Super-royal 8vo. 31s. $6 d$.

Moore's Irish Melodies, 32mo. Portrait, 1s. 16mo. Vignette, 2s. $6 d$. Square crown 8vo. with 13 Plates, $21 s$.

SOUTHEY'S POETICAL WORKS, with the Author's last Corrections and copyright Additions. Library Edition, in 1 vol. medium 8vo. with Portrait and Vignette, 14s, or in 10 vols. fep. $3 s$. $6 d$. cach.

LAYS of ANCIENT ROME; with Ivry and the Armada. By the Right Hon. LORD MACAULAY. 16mo. $4 s .6 d$.

Lord Macaulay's Lays of Ancient Rome. With 90 Illustrations on Wood, Original and from the $\Lambda$ ntique, from Drawings by G. Scrarp. Fep. 4to. $21 s$.

PoEms. By Jedn Ingelow. Seventh Edition. Fcp. 8vo. 5s.

POETICAL WORKS of IETITIA ELIZABETH IANDON (I.E. L.) 2 vols. $16 \mathrm{mo}, 10 s$.

PLAYTIME with the POETS : a Selection of the best English Poetry for the use of Children. By a Ladr. Crown 8vo. $5 \mathrm{~s}$.

The REVOLUTIONARY EPICK, By the Right Hon. BenJamix DisRaeli. Fep. 8vo.5s.

BOWDLER'S FAMILY SHAKSPEARE, cheaper Genuine Edition, complete in 1 vol. large type, with 36 Woodeut Illustrations, price 14s. or with the same ILLUSTRATIOxs, in 6 pocket vols. 5 s. each.

An ENGLISH TRAGEDY; Mary Stuart, from Scniller ; and Mdlle. De Belle Isle, from $\Lambda$. Dumas,-each a Play in $5 \Lambda$ cts, by Frances $\Lambda$ Nre KeMBLE. Post 8vo. 12s.

$$
\text { Rural Sports, } \& c \text {. }
$$

ENCYCLOPADIA of RURAI SPORTS; a complete Account. Historical, Practical, and Descriptive, of Hunting, Slooting, Fishing, Racing, \&c. By D. P. Blaine. With above 600 Woodcuts (20 from Designs by JoII LEECII). 8vo. 42s. 
COL. HAWRER'S INSTRUCTIONS to YOUNG SPORTSMEN in all that relates to Guns and Shooting. Revised by the Author's Sov. Square crown 8vo. with lllustrations, $18 s$.

NOTES on RIFLE SHOOTING. By Captain Heatos, Adjutant of the Third Manchester Rifle Volunteer Corps. Fcp. 8vo. $2 s .6 d$.

The DEAD SHOT, or Sportsman's Complete Guide; a Treatise on the Use of the Gun, Dog-breaking, Pigeon-shooting, \&c. By Marksmax. Fep. 8vo. with Plates, $5 s$.

The CHASE of the WILD RED DEER in DEVON and SOMERSET. By C. P. Collyns. With Map and Illustrations. Square crown 8vo. $16 s$.

The FLY-FISHER's ENTOMOLOGY. By Alfred Ronalds. With coloured Representations of the Natural and Artificial Insect. 6th Edition; with 20 coloured Plates. 8vo. 14s.

HANDB00K of ANGLING : Teaching Fly-fishing, Trolling, Bottomfishing, Salmon-fishing; with the Natural History of River Fish, and the best modes of Catching them. By EPHemers. Fep. Woodcuts, $5 s$.

The CRICKET FIELD ; or, the History and the Science of the Game of Cricket. By J. Pycrort, B.A. Trin. Coll. Oxon. 4th Edition. Fep. svo. $5 s$.

The Cricket Tutor; a Treatise exclusively Practical. By the same. 18mo. $1 s$.

The HORSE'S FOOT, and HOW to KEEP IT SOUND. By W. Miles, Esq. 9th Edition, with Illustrations. Imp. 8vo. 12s. $6 d$.

A Plain Treatise on Horse-Shoeing. By the same Author. Post Svo. with Illustrations, $2 s$.

General Remarks on Stables, and Examples of Stable Fittings. By the same. Imp. 8vo. with 13 Plates, 15s.

Remarks on Horses' Teeth, adapted to Purchasers. By the same Author. Crown 8vo. 1s.6d.

The HORSE: with a Treatise on Dranght. By William Youatr. New Edition, revised and enlarged. 8vo. with numierous Woodcuts, $10 s$. $6 d$.

The Dog. By the same Author. 8vo. with numerous Woodcuts, is.

The DOG in HEALTH and DISEASE. By Stonenenge. With 70 Wood Engravings. Square crown 8vo. 15s.

The Greyhound. By the same. With many Illustrations. Square crown 8vo. $21 s$.

The OX; his Diseases and their Treatment: with an Essay on Parturition in the Cow. By J. R. Dobsox, M.R.C.V.S. Post 8vo. with Illustrations. 


\section{Commerce, Navigation, and Mercantile Affairs.}

The LAW of NATIONS Considered as Independent Political Communities. By Travers Twiss, D.C.L. Regius Professor of Civil Law in the University of Oxford. 2 vols. 8vo. 30s. or separately, PART I. Peace, 12 s. PART II. War, $18 s$.

A DICTIONARY, Practical, Theoretical, and Historical, of Commerceand Commercial Navigation. By J. R. M'CeLLOCH, Esq. Svo. with Maps and Plans, 50s.

The STUDY of STEAM and the MARINE ENGINE, for Young Sea Officers. By S. M. SAXBY, R.N. Post 8vo. with 87 Diagrams, 5s.6d.

A NAOTICAC DICTIONARY, defining the Technical Language relative to the Building and Equipment of Sailing Vessols and Steamers, \&c. By ArThUr Yousg. Second Edition; with Plates and 150 Woodcuts. 8vo. 18s.

A MANOAL for NAVAL CADETS. By J. M'NeIL Boyd, late Captain R.N. Third Edition; with 240 Woodcuts and 11 coloured Plates. Post 8vo.12s. $6 d$.

*** Every Cadet in the Royal Navy is required by the Regulations of the Admiralty to have a copy of this work on his entry into the Navy.

\section{Works of Utility and General Information.}

MODERN COOKERY for PRIVATE FAMILIES, reduced to a System of Easy Practice in a Series of carefully-tested Receipts. By EuIzA ACTOx. Newly revised and enlarged; with \& Plates, Figures, and 150 Woodcuts. Fep. 8vo.7s. $6 d$.

On FOOD and its DIGESTION ; an Introduction to Dietctics. By W. Brivtov, M.D. Physician to St.Thomas's Hospital, \&c. With 48 Woodcuts. Post 8vo. 12s.

ADULTERATIONS DETECTED; or Plain Instructions for the Discovery of Frauds in Food and Medicine. By A. H. HAssalL, M.D. Crown $8 \mathrm{vo}$. with Woodeuts, $17 s .6 d$.

The VINE and its FRUIT, in relation to the Production of Wine. By James L. Denman. Crown 8vo. 8s.6d.

WINE, the VINE, and the CELlar. By Thomas G. Shaw. With 28 Illustrations on Wood. 8vo. 16s.

A PRACTICAL TREATISE on BREWING; with Formulx for Public Brewers, and Instructions for Private Families. By W. BLACK. 8vo. 10s.6d.

SHORT WHIST; its Rise, Progress, and Laws; with the Laws of Piquet, Cassino, Ecarté, Cribbage, and Backgammon, By Iajor $\mathbf{\Lambda}$. Fep. 8 vo. 3s. 
HINTS on ETIQUETTE and the USAGES of SOCIETY; with a Glance at Bad Habits. Revised, with Additions, by a LADY of RANK. Fep. 8vo. 2s. $6 d$.

The CABINET LAWYER ; a Popular Digest of the Laws of England, Civil and Criminal. 19th Edition, extended by the Author; including the Acts of the Sessions 1862 and 1863. Fcp. 8vo. 10s. 6d.

The PHILOSOPHY of HEALTH; or, an Exposition of the Physiological and Sanitary Conditions conducive to Human. Longevity and Happiness. By SouTHwood SMITI, M.D. Eleventh Edition, revised and enlarged: with New Plates, 8vo.

[Just ready.

HINTS to MOTHERS on the MANAGEMENT of their HEAITH during the Period of Pregnancy and in the Lying-in Room. By T. BuLL, M.D. Fep. Svo.5s.

The Maternal Management of Children in Health and Disease. By the same Author. Fcp. 8vo. 5s.

NOTES on hospitals. By Florence Nightivgale. Third Edition, enlarged; with 13 Plans. Post 4to. 18s.

C. M. WILLICH'S POPULAR TABLES for ascertaining the Value of Lifehold, Leasehold, and Church Property, Renewal Fines, \&c.; the Public Funds; Annual Average Priee and Interest on Consols from 1731 to 1861; Chemical, Geographieal, Astronomical, Trigonometrical Tables, \&c. Post 8vo. 10s.

THOMSON'S TABLES of INTEREST, at Three, Four, Four and a Half, and Five per Cent. from One Pound to Ten Thousand and from 1 to 365 Days. 12mo. $3 s .6 d$.

MAUNDER'S TREASURY of KNOWIEDGE and IIBRARY of Reference: comprising an English Dictionary and Grammar, a Universal Gazetteer, a Classical Dictionary, a Chronology, a Law Dictionary, a Synopsis of the Peerage, useful Tables, \&c. Fep. 8vo. 10s.

\section{General and School Atlases.}

An ELEMENTARY ATLAS of HISTORY and GEOGRAPHY, from the commencement of the Christian Era to the Present Time, in 16 eoloured Maps, chronologieally arranged, with illustrative Memoirs. By the Rev. J. S. BREWER, M.A. Royal 8vo.12s. 6d.

SCHOOL ATLAS of PHYSICAL, POLITICAL, and COMHERCIAL GEOGRAPHY, in 17 full-eoloured Maps, accompanied by deseriptive Letterpress. By E. HUGHES, F.R.A.S. Royal 8vo. 10s. $6 d$.

BISHOP BUTLER'S ATLAS of ANCIENT GEOGRAPHY, in a Series of 24 full-coloured Maps, aecompanied by a complete Accentuated Index. New Edition, corrected and enlarged. Royal 8vo. 12s. 
BISHOP BUTLER'S ATLAS of HODERN GEOGRAPHY, in a Scries of 33 full-coloured Maps, accompanied by a complete Alphabetical Index. New Edition, corrected and enlarged. Royal 8vo. 10s.6d.

Is consequence of the rapid advance of geograplitical discovery, and the many recent changes, through political causes, in the boundaries of various countries, it has been found necesssry thoroughly to revise this long-established Atlas, and to add eeveral new MAPS. New Maps have been given of the following countries: Palestine, Canada, and the adjacent provinces of New Brunswick, Nova Scotia, and Nerofoundland, the American States bordering on the Pacific, Eastern Australia, and New Zealand. In addition to these MAPS of Western Australia and Tasmania have been given in compartments: thus completing the revision of the MAP of Australasia, rendered necessary by the rising importance of our Australasian possessions. In the MAP of Europe, Iceland has also been re-drawn, and the new boundaries of France, Italy, and Austria represented. The M APS of the three last-named countries have been carefully revised. The MAP of Switzerland has been wholly re-drawn, showing more accurately the physical features of the country. Africa has been carefully compared with the discoveries of LIVINGSTON R, BURTON, SPBKB, BARTH, and other explorers. The number of MAPs is thus raised from Thirty to Thirty-three. An entirely new IN Dax has been constructed; and the price of the work has been reduced from 128, to Half-a-Gninea. 'The present edition, therefore, will be found much superior to former ones: and the Publishers feel assured that it will maintain the cluaracter which this work has so long enjoyed as a popular and comprehensive School Atlas.

MIDDLE-CLASS ATLAS of GENERAI GEOGRAPHY, in a Series of 29 full-coloured Maps, containing the most recent Territorial Changes and Discoveries. By WaLter M'LEOD, F.R.G.S. 4to. $5 s$.

PHYSICAL ATLAS of GREAT BRITAIN and IRELAND; comprising 30 full-coloured Maps, with ill ustrative Letterpress, forming a Concise Synopsis of British Physical Geography. By WALTER M'Leod, F.R.G.S. Fep. 4to. 7s. $6 d$.

\section{Periodical Publications.}

The EDINBURGH REVIEW, or CRITICAL JOURNAL, published Quarterly in January, A pril, July, and October. 8vo. price 6s, each No.

The GEOIOGICAL MAGAZINE, or Monthly Jonrnal of Geology, edited by T. RUPERT JoNes, F.G.S. assisted by HENRY WOODWARD, F.G.S. 8vo. price 1s.6d. each No.

FRASER'S MAGAZINE for TOWN and COUNTRY, published on the 1st of each Month. 8vo. price 2s. $6 d$. each No.

The ALPINE JOURNAL: a Record of Mountain Adventure and Scientific Observation. By Members of the Alpine Club. Edited by H. B. George, M.A. Published Quarterly, May 31, Aug. 31, Nov. 30, Feb. 28. 8vo. price 1s, $6 d$, each No. 


\section{INDEX.}

Acrov's Modern Cookery

Aftermoon of rife

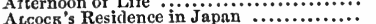

Alpine fuide (The)

Journal (The)

Apjons

Apjors's Biographies of Scientific Mcn .....

Popular Astronomy.................

Meteorological Essays .............

A RYo D's Manual of Englisls Literature.....

A rort's Elements of Physics...............

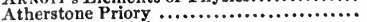

A tк ז́son's Papinian..........................

Autumn Holiday of a Country PARson....

Ax\& E's Treasury of Bible Knowledge.......

Bacos's Essays, by Wnately .............. Life and Letters, by SProdino...... Works, by ErLis SPEDUINo, and

HFATH

BAIN on the Emotions ä.

_ on the Senses and Intellect............... on the Study of Character ..............

BaINF's Fxplorations in S. W. Africa....

BALL's Guide to the Central Alps ............. Guide to the Western Alps.............

BAyr.pos's Rents and Tillages...............

Berlepsra's Life and Nature in the Alps...

BuAck's Treatise on Brewing ...............

BLACKI.EY and FniedLAN DEr's German and

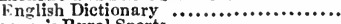

Bratne's Rural Sports ......................

Brtoнt's Week at the Land's End ...........

Bounsz's Catechism of the Steam Enuine.. Treatise on the Steam Engine...

BowdLER's Family SHARSPEARR .............. Boyv's Manual for Naval Cadetg.

Brauryy-MIong's Six Sisters of the Valleys

BRANDE's Dictionary of Science, Literature,

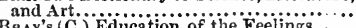

Basx's (C.) Education of the Feelings...... Philosophy of Neces

Breweit's Atlas of History and Geography

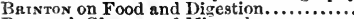

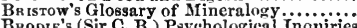

Brode's (Sir C. B.) Paychological Inquiries

Bnows's Demonstrations of Microscopic

Anatomy.................................

Browns's Fxposition of the 39 Articles......

Pentateuch and Elohistic Psalm

Buckis's Ifistory of Civilization $\ldots \ldots \ldots \ldots$

Maternal Management of Children.
Bursex's Analecta Ante-Nicrna ......... 19 Ancient Egypt ................... 3

IIinpolytus and $\mathrm{his}$ Age .............. 19

Philosopliy of Universal History 19

BUNYAN's Pilgrim's Progress, illustrated by

BennetT............................. 15

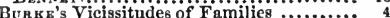

Butere's Atlas of Ancient Geography ...... 27 Modern Geography .............. 28

Cabinet Lawyer

CALvert's Wife's, Manual .................. 20

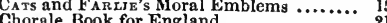

Corenso (Bishop) on Pentateuch and Book $^{\circ}$ of Joshna ............................ 18

revs on Stag-Hunting in Devon and

Somerset .............................

ommonplace Philosopher in Town and

Country ................................

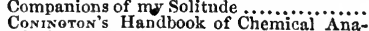
lysis ......................... 13

Contanseao's Pocket French and English Dictionary Practical ditto.................. Conybars and Howson's Life and Ë......

of St. Paul . Copzand's Dictionary of Practicai Miedicine 14 Coтron's Introduction to Confirmation ....... is Cox's Tales of the Great Persian War..... 2

Tales from Greek Mythology ........ 23

Tales of the Gods and Heroes .........

Tales of Thebes and Argos ............ 23

Cresy's Encyclopædia of Civil Engineering 16

Crowe's History of France ................

D'Aurigns's History of the Reformation in the time of C

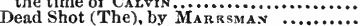
DR LA Rrve's Treatise on Electricity ....... il Drenan's Vine and its Fruit .............. 26 De Tocqueville's Democracy in America... 2 Diaries of a Lady of Quality ............... DisRakitis Revolutionary Epick.............. 24 Dixon's Fasti Eboracenses ..................... 4

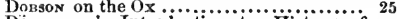
DólLINoER's Introduction to History of

Christianity ............................ 19

Dove's Law of Storms ........................... 19

Doyse's Chronicle of England,................ 2 


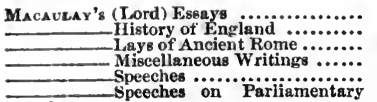

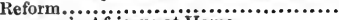

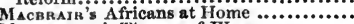

Macdovoald's Theory of War.............. McLnod's Middle-Class Atlas of General Geography ............................. aud Ireland McCulLoch's Dictionary of Commeree....... McCulnoch's Dictionary of Commerce ...... Mavuraz's Life of Father Mathew............. Rome and its Rulers.

Mano's Indoor Gardener ......

Maps from Peaks, Passes, and Giaciers .... Marsiarz's History of Christian Missions. Massey's History of England ...............

Ma under's Biographical Treasury ........... Geographical Trensury ........ Historical Treasury ................ Scientific and Literary Treasury Treasury of Knowledge ......... Treasury of Natural History ..

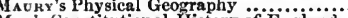

MAY's Constitutional History of England.

Melville's Digby Grand.................... General Bounce ................. Gladiators

Good for Nothing..............

Holmby House ...................

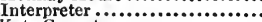

Kate Coventry ...................

Queen's Maries....................

Mendetssonn's Letters.

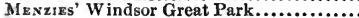

Merivale's (H.) Colonisation and Colonies (C.) Fall of the Roman Republic Romans under the Empire

Meryon's History of Medicine.............

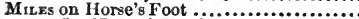

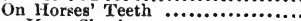

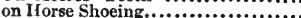
on Stables.

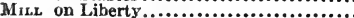

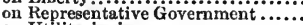

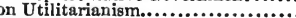

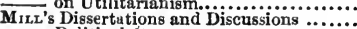
Political Economy .................

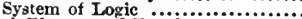

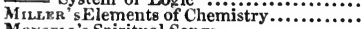

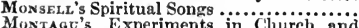

Montagc's Experiments in Cliurch and

State............................................

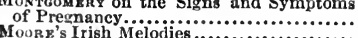

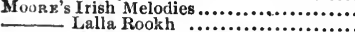
Memoirs, Journal, and Correspon-

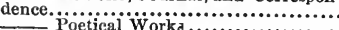

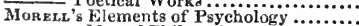

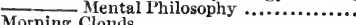

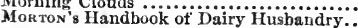
Farm Labour...... Prince Consort's Farms............ Mosnerm's Ecclesiastical I listory ................ M̈̈urrR's (Max) Lectures on tle Scicnce of

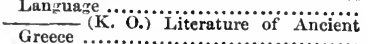

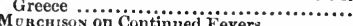
Murchison on Continued Fevers............
New Testament illustrated with Wood Engravings from the Old Musters........... 15 NEwMax's Apologia pro Vitâ Suá ............ 3 Nightisaans's Notes on Hospitals.......... 27

Opujno's Course of Practical Chemistry .... 13 Manual of Chemistry ............. 13 Or wssy's Kambles in Algeria and Tunis..... 21 Owex's Comparative Anatomy and Physio-

logy of Vertebrate Animals ..............

Packe's Guide to the Pyrenees ............ 22 PAger's Lectures on Surgical Pathology... 14

Parker's (Theodore) Life, by Werss....... 4 Peaks, Passes, and Glaciers, 2 Series .......... 21 Prkaira's Elements of Materia Medica.... 15 Perars Manual of Materia Medica ...... is Prings's 'Tuide to Phillips's Guide to Geology .............. II PIEsse's A Int of Perfumery Mineralogy ...... 11 Chemical, Natural, and Physicai Magic ... Laboratory of chemical wo............... 17 Playtime with the Poets ..................... 17 Practical Mechanic's Journal ................... 16 Prescotr's Scripture Difficulties ............... 18 Problems in Human Nature................. 20

Pxcrorts Course of English Reading....... 7 - Cricket Field .................... 25

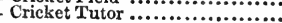

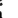

Recreations of a Country Parson, Secowo

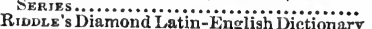
Rivers's Rose Amateur's Guide............. Rogers's Correspondence of Greyson ......... 9

- Eelipse of Faith ................ 9

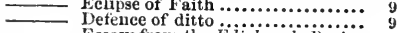

— Essays from the Edinburgh Review 9 Fulleriana......................

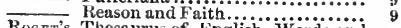
Roger's Thesaurus of English Words and

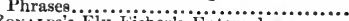

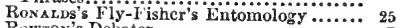
Rowrox's Debater.................... 
SAxBy's Study of Steam

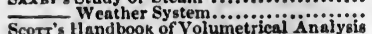
Scorr's Handbook of Volumetrical Analysis

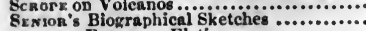

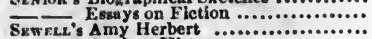

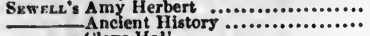

Cleve II I li.......

0
0

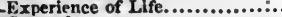

Gertrude

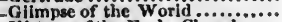

History of the Enrly Church......

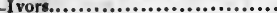

Katharine Ashton

- Ianeton Parzonace. . ...............

- Marzaret Percival

Night Iessons from Scripture .....

Pasing Thoughts on Religion...

Preparation for Communiou .......

Readings for Confirmation......... - Keadiugs for Lent ................

mation

Stories and $T$ ales ...................

Thoughts for the IIoly Weck ......

Ursuia

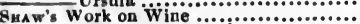

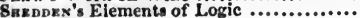

Short Whist

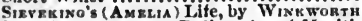
8aitu's (Sovtrwood) Philosophy of Health siru s (JovTRwoob) Philosophy of Health

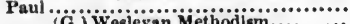
G.) Srover) Memoir and Letters ......... Miscellancous Works...... Sketches of Moral Plilio-

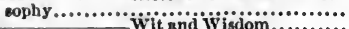

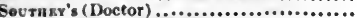

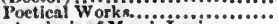

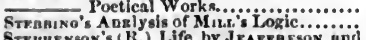
StrineneoN's (R.) Life by Jratrasson und

Pore . . . . .......................

Strkarx's Eesay in Ecclesiastical Biography.................................. History of

France...............................

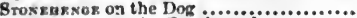

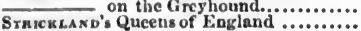

TArzoR's (Jeremy) Works, edited by EDvN Trknant's Ceylon $\ldots$ i....................... Naturul ii isiory of Cẹion.......

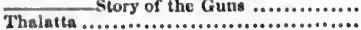

26

10

13

11

5

23

23

VAn HoRVus's Handbook of Zoology.. Vavoran's (It.) Revolutions in English

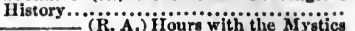

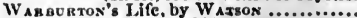

W ARTER's Last of the Old Squires................

Warson's Principles und Practice of Physic

WArrs's Dictionary of Chemistiy.......... I

W Eas's Celestiai Objects for Common Tele. scopes .............................. 10

WrastrR \& WiLkrkson's Greek Testanent 18

Wern's Last Winter in Rome............... 21

WrLlinoton's Iife, by Baianow and

Grero ..............................

Wester's I ife, by Souther Greio ............

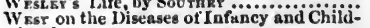

hood ...............................

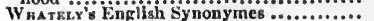

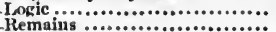

Remains

Wakwren's llistory of the Inductive Sci-

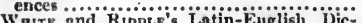

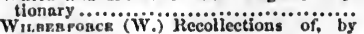

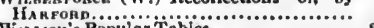

W

Wilsox's Brvologia Britannica ............ 1:

Woov's Homes without IIands................ II

Woonwan's IItotorieal and Chronological

Encyclopadia ........................

Yoxen's Enplish-Greek Iexicon ..........

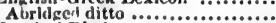

Youna's Nuuticul Dictionary ............. 26

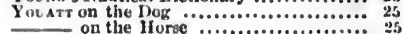





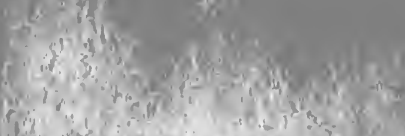

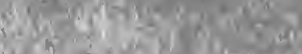

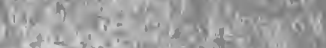

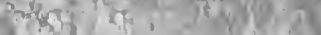

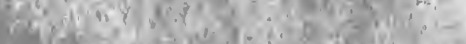

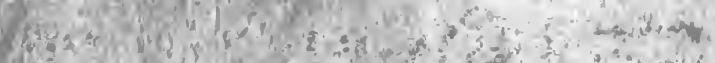

4.

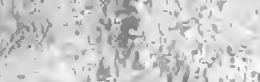

$$
\begin{aligned}
& \text { No } 140 . \cdots
\end{aligned}
$$

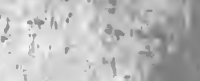

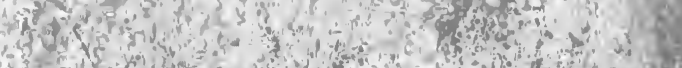

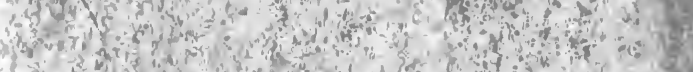

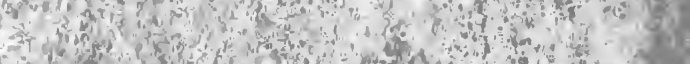

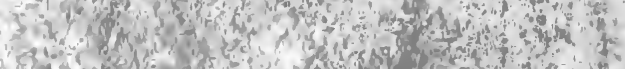

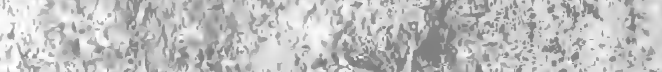

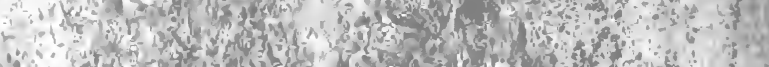

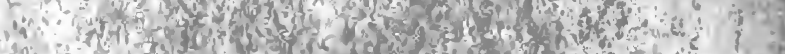

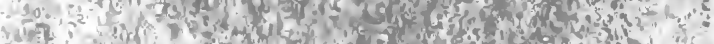

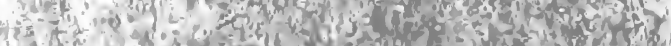

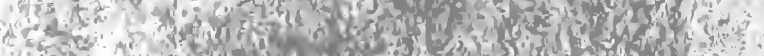
Fi A N

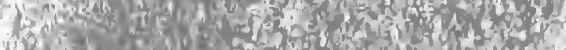

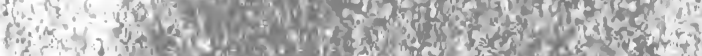

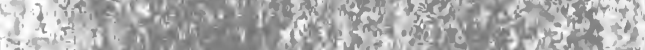
(1)

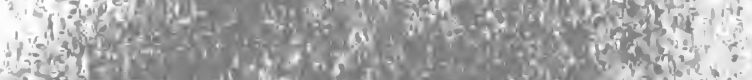

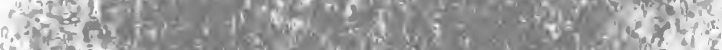

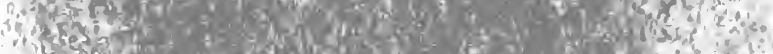

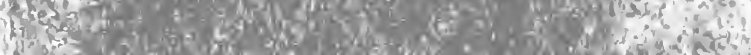

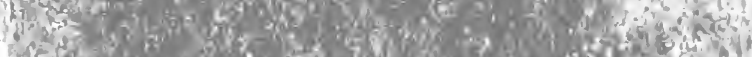

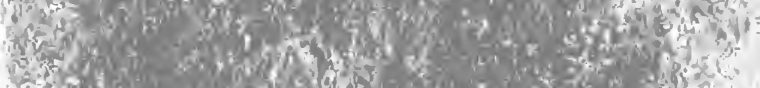

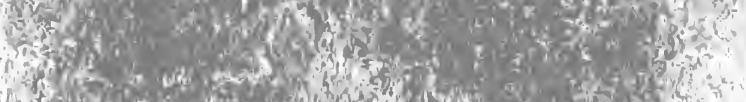

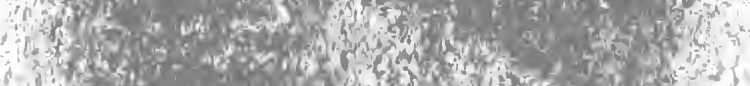

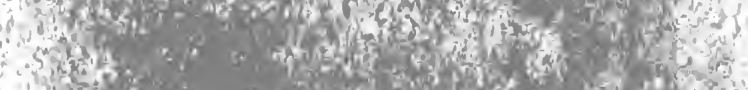

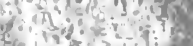
4

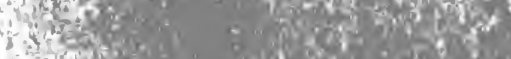

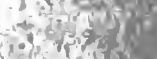
isal sol:

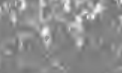

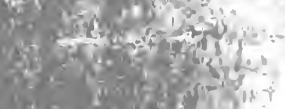

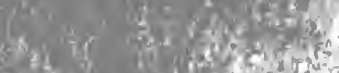
sondis

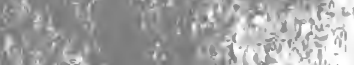




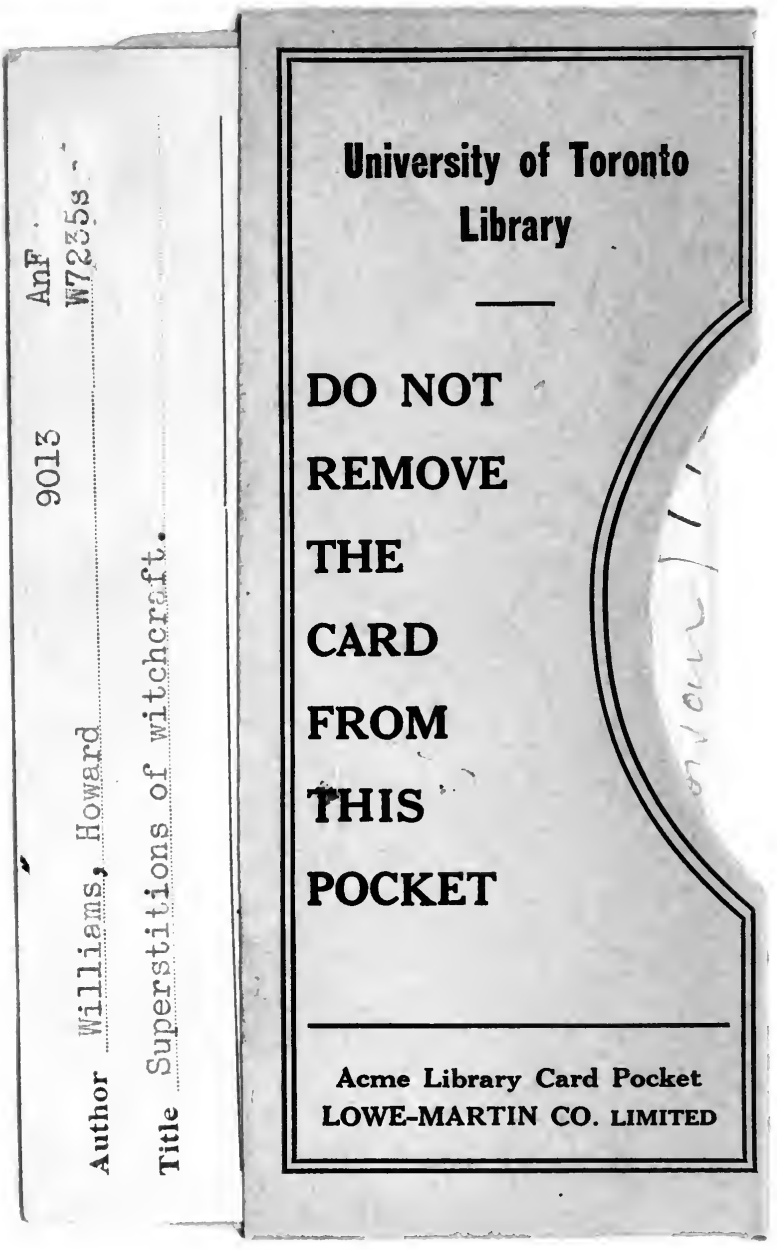


